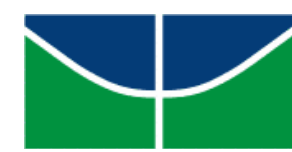

UNIVERSIDADE DE BRASÍLIA

INSTITUTO DE PSICOLOGIA

Programa de Pós-Graduação em Processos de Desenvolvimento Humano e Saúde

VIOLÊNCIA E PAZ: CONSTRUÇÃO DE CONCEITOS, VALORES E POSICIONAMENTOS DE OFICIAIS DA POLÍCIA MILITAR

Letícia de Sousa Moreira

Brasília, Março de 2016 
Moreira, Letícia de Sousa

MM838v Violência e Paz: Construção de Conceitos, Valores e Posicionamentos de Oficiais da Polícia Militar / Letícia de Sousa Moreira; orientador Angela Maria Cristina Uchoa de Abreu Branco. -- Brasília, 2016. $236 \mathrm{p}$.

Tese (Doutorado - Doutorado em Processos de Desenvolvimento Humano e Saúde) -- Universidade de Brasilia, 2016.

1. Cultura de Paz. 2. Violência. 3. Construção de Valores. 4. Polícia Militar. I. Maria Cristina Uchoa de Abreu Branco, Angela, orient. II. Título. 


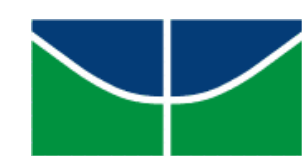

UNIVERSIDADE DE BRASÍLIA

INSTITUTO DE PSICOLOGIA

Programa de Pós-Graduação em Processos de Desenvolvimento Humano e Saúde

\title{
VIOLÊNCIA E PAZ: CONSTRUÇÃO DE CONCEITOS, VALORES E POSICIONAMENTOS DE OFICIAIS DA POLÍCIA MILITAR
}

Letícia de Sousa Moreira

\begin{abstract}
Tese apresentada ao Programa de PósGraduação em Processos de Desenvolvimento Humano e Saúde, como requisito parcial à obtenção do título de Doutor, com área de concentração em Desenvolvimento Humano e Educação.
\end{abstract}

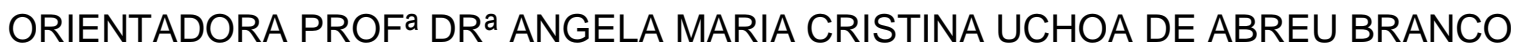




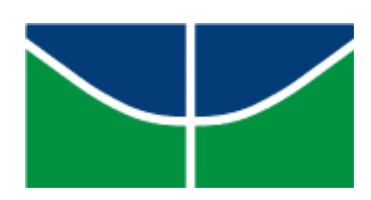

$$
\begin{aligned}
& \text { UNIVERSIDADE DE BRASÍLIA } \\
& \text { INSTITUTO DE PSICOLOGIA }
\end{aligned}
$$

Programa de Pós-Graduação em Processos de Desenvolvimento Humano e Saúde

TESE DE DOUTORADO APROVADA PELA SEGUINTE BANCA EXAMINADORA:

Prof ${ }^{a}$. Drª . Angela Maria Cristina Uchoa de Abreu Branco - Presidente Universidade de Brasília - Instituto de Psicologia

Prof ${ }^{a}$. Drª . Vannúzia Leal Andrade Peres - Membro Externo

Pontifícia Universidade Católica de Goiás - Departamento de Psicologia

Prof. Dr. Arthur Trindade Maranhão Costa - Membro

Universidade de Brasília - Departamento de Sociologia

Prof. Dr. Francisco José Rengifo Herrera - Membro

Centro Universitário de Brasília - Departamento de Psicologia

Prof ${ }^{a}$. Dr ${ }^{\mathrm{a}}$. Diva Maria Moraes Albuquerque Maciel - Membro

Universidade de Brasília - Instituto de Psicologia

Prof ${ }^{\mathrm{a}}$. Dr ${ }^{\mathrm{a}}$. Teresa Cristina Siqueira Cerqueira - Suplente

Universidade de Brasília - Faculdade de Educação

Brasília, Março de 2016 


\section{AGRADECIMENTOS}

A DEUS, autor da vida, por tantos milagres, tanto carinho e cuidado, por ter providenciado tudo no momento certo e por ter me conduzido até aqui. A Ele toda honra e glória!

À minha querida orientadora ANGELA BRANCO, pela caminhada tão cheia de significados e repleta de ensinamentos, pela doação, pela compreensão nos momentos difíceis e, sobretudo, pela confiança;

Aos meus FAMILIARES por compartilharem valores humanos, pelo companheirismo afetuoso, assessorias diversas, sem nunca perderem a fé em mim;

Ao COMANDO DA POLÍCIA MILITAR, pela credibilidade e apoio na realização deste trabalho. Aos PARTICIPANTES dessa pesquisa, pela confiança, entrega e desejo de transformações. A todos os meus COLEGAS policiais militares que estiveram ao meu lado durante toda essa caminhada; por me incentivarem a seguir em frente apesar de tantos percalços enfrentados ao longo dessa trajetória;

Aos meus AMIGOS (todos), fiéis presenças a me proporcionarem uma palavra de ânimo ou consolo, me fazendo ver além dos horizontes teóricos;

Aos PROFESSORES e COLEGAS do PGPDS, pela valiosa convivência durante essa etapa, enriquecendo nossas discussões e grupos de pesquisa que tanto me fizeram avançar nos meus processos desenvolvimentais. À PAULA, que me auxiliou com as transcrições;

Aos COLEGAS da SENASP, pelo apoio e companheirismo;

Ao LEONARDO, meu core, que chegou no meio desse projeto, assumiu o desafio e me ajudou a finalizar essa conquista com a chave do amor. Ao MIGUEL, meu príncipe e coautor desse trabalho, que está sendo formado durante a etapa final dessa tese e ajudou mamãe a ampliar os campos afetivo-semióticos que nos envolvem. A vocês dois, meus tesouros, minha profunda gratidão por toda a parceria!

Enfim, a todos que de maneira direta ou indireta estiveram presentes nessa caminhada, às vezes tranqüila, às vezes angustiante e turbulenta, caminhando entre rosas e espinhos, enchentes e desertos, mas que comigo venceram mais essa etapa e deixaram seus nomes gravados eternamente em meu coração. Vocês são parte fundamental dessa conquista!

A todos vocês MUITO OBRIGADA! Que Deus os recompense em dobro por toda a doação e que os valores de Paz prevaleçam em nossas vidas! 


\section{RESUMO}

Questões que envolvem paz e violência, para serem analisadas e discutidas, exigem investigar os complexos processos de construção desses dois conceitos, sobretudo se considerarmos que seus significados estão profundamente enraizados nas dimensões histórico-cultural e psicológica dos fenômenos sociais. Estudar e refletir sobre tais fenômenos tem sido objeto de estudo constante, sobretudo no âmbito das ciências sociais e, mais recentemente, da psicologia. A partir da perspectiva teórico-metodológica da Psicologia Cultural, propomos uma visão de sujeito que se transforma constantemente em interação com o contexto histórico-cultural que também se desenvolve, compreendendo que a ação humana é fruto dessas interações. Consideramos paz e violência como conceitos complexos e complementares, diretamente relacionados aos valores humanos, os quais surgem de práticas culturais de acordo com um processo dinâmico de mútua constituição. A construção e o desenvolvimento de valores relacionados à paz e à violência no contexto da instituição militar, e o papel da cultura nesse processo, é o foco da presente pesquisa, a qual se insere na perspectiva de possíveis transformações no contexto social. Considerando o contexto sócio-histórico cultural da Polícia Militar do Estado $\mathrm{X}$, este estudo objetivou analisar e compreender os múltiplos componentes dos conceitos de violência, sua prevenção, e a promoção da Cultura de Paz apresentados por policiais militares. A metodologia utilizada foi qualitativa, sendo realizadas entrevistas individuais semi-estruturadas e grupos focais, onde os indicadores empíricos foram construídos ao longo do processo de interação pesquisador-pesquisado. Do total de entrevistas, foram selecionadas três entrevistas individuais com os Cadetes (alunos do Curso de Formação de Oficiais - CFO) e três com os Tenentes (Oficiais com dois anos de formados), sendo em cada grupo dois homens e uma mulher. Em seguida, foi realizada uma sessão de grupo focal com cada grupo, e uma entrevista individual com o coordenador e uma instrutora do CFO. O procedimento de análise seguiu o modelo construtivo-interpretativo. A partir dos resultados obtidos verificou-se que os participantes, de maneira geral, apresentaram conceitos e explicações pouco aprofundadas e de sensocomum sobre paz e violência. Os participantes afirmam que o curso de formação da PM orienta bem os alunos em relação à temática da violência, porém admitem que as práticas da PM envolvem violência e mais repressão que prevenção. Os participantes apresentaram posicionamentos críticos em relação a alguns valores da cultura militar, identificando a hierarquia como algo bom, porém, mal utilizado por alguns superiores. Eles também apontaram para alguns aspectos contraditórios da formação, como a promoção da competição e a expectativa da lealdade. Houve mobilização afetiva a partir das imagens e vídeo utilizados no método, envolvendo violência policial e contra o policial, o que favoreceu a identificação de seus posicionamentos em relação ao tema investigado. $O$ trabalho permitiu, portanto, identificar e analisar os processos ligados a sociogênese dos 
valores humanos, podendo contribuir para uma discussão ampla que possibilite o envolvimento da Polícia Militar como instituição promotora da Cultura de Paz no contexto da sociedade com o intuito de dar início à elaboração e implantação de programas de formação para construção da cultura da paz no âmbito da Polícia Militar.

Palavras-chave: Paz, violência, cultura, valores, Polícia Militar. 


\section{ABSTRACT}

To analyze and discuss issues involving violence and peace we need to investigate the complex processes participating of the construction of the two concepts. Particularly when we consider their meanings deeply rooted in historical cultural and psychological dimensions of social phenomena. To study and reflect upon such phenomena is a permanent endeavor of social sciences and, more recently, of psychology. From a Cultural Psychology theoretical-methodological perspective, we claim that human subjects continuously transform as they interact with the also developing historical-cultural context, and human conducts results from such interactions. Peace and violence are complementary and complex concepts, directly related to human values, and they emerge from cultural practices according to a dynamic process of mutual constitution. The construction and development of values related to peace and violence within the context of military institution, and the role played by culture in this process, is the aim of this research, which endorse the possibility of social contexts transformations. Taking into account the cultural socio-historical context of the Military Police of the State $\mathrm{X}$, the study focused on the analysis an understanding of the multiple components found in the definition of violence, its prevention and the promotion of a culture of peace among the militaries. A qualitative methodology included semi-structured individual interviews and focal groups, in order to provide empirical indicators constructed in the interactions between the researcher and the participants. From the individual interviews, three of the cadets' (students of the Military Police Academy), and three of the lieutenants' (with two years of graduation) were selected for analysis, in both cases two men and one woman. After, a focal group session was conducted with each group, and individual interviews were carried out with a teacher and the coordinator of the Academy. From an interpretative-constructive analytical approach, we verified that participants, in general, produced superficial and common sense concepts and explanations about violence and peace. They affirmed the Academy course well prepare them regarding the topic of violence, but also agree that Military Police practices involve violence, and, according to them, repression dominates over prevention. Cadets and lieutenants presented a critical appraisal concerning some of the military culture values, and identified hierarchy as something good that can be ill-used by superiors. The identified contradictory aspects in the military education, giving as example the promotion of competition in contrast with expectations of loyalty. The photos and videos used in the method, depicting violence by, or directed to, militaries, stirred emotions that helped to identify their positionings regarding the investigated topics. In sum, the research was able to identify and analyze sociogenetic processes promoting human values, and, therefore, contribute to discussions that may allow for changes in the Military Police. If so, it can actively sponsor practices conducive to a Culture of Peace in society, such as the 
elaboration and implementation of educational programs aiming at the construction of a peace culture within the Military Police.

Key-words: Peace, violence, culture, values, Military Police. 


\section{LISTA DE TABELAS}

Tabela 1 - Informações sobre os oficiais participantes da pesquisa 53 


\section{SUMÁRIO}

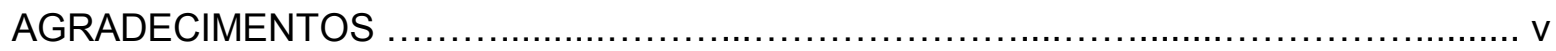

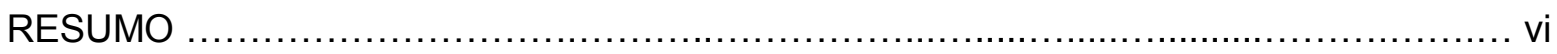

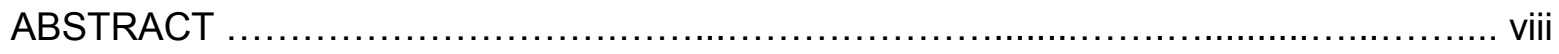

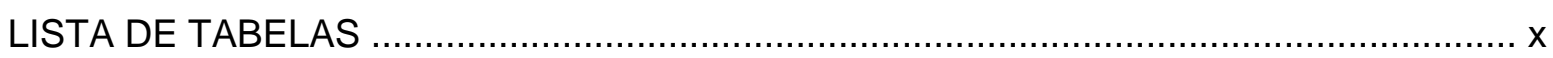

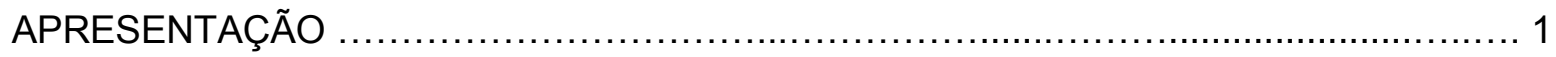

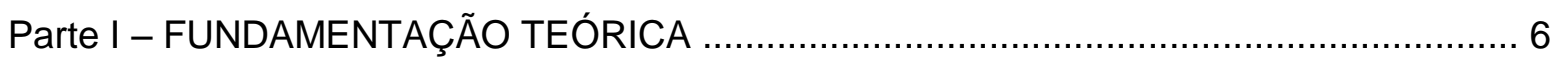

Capítulo 1 - Desenvolvimento Humano e Cultura.......................................................... 6

1.1 - Fundamentos da Psicologia Cultural: a Perspectiva Sociocultural Construtivista 6

1.2 - Sociogênese dos Valores Sociais: A Constituição Mútua de Práticas Culturais

e Processos de Significação .............................................................................. 14

Capítulo 2 - Violência e Paz: aspectos teórico-conceituais .......................................... 18

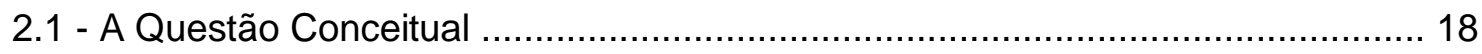

2.2 - Conflitos: Conceito, Função Desenvolvimental e Mediação ................................. 22

2.3 - A Dimensão Sócio-Moral do Desenvolvimento Humano e a Cultura de Paz:

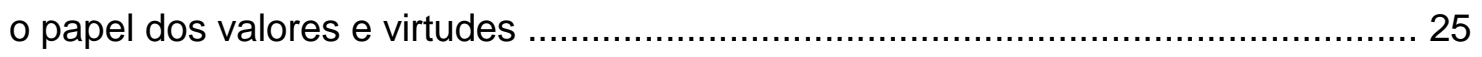

Capítulo 3 - Polícia Militar e Cultura Institucional ......................................................... 34

3.1 - A Instituição: Missão e Atuação Social ........................................................ 34

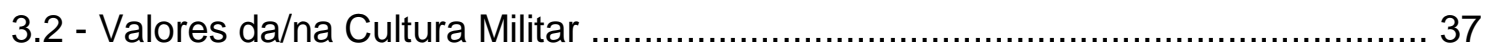

3.3 - A Formação de Oficiais na Polícia Militar ....................................................... 39

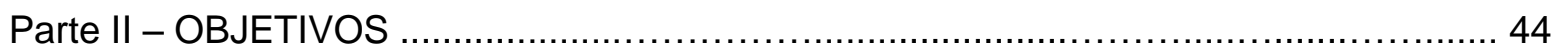

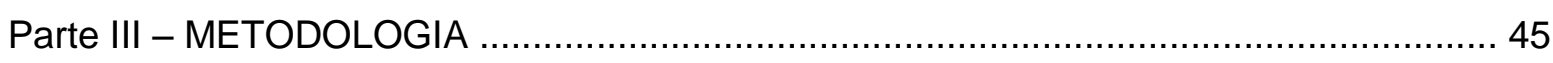

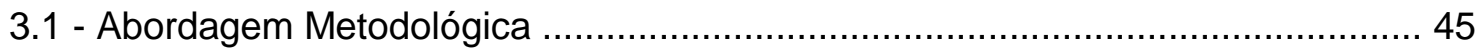

3.1.1 - Entrevista como processos de significação ........................................... 45

3.1.2 - Grupo Focal como espaço dialógico para investigação ............................. 46

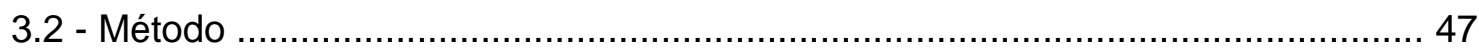

3.2.1 - Contato com a Polícia Militar do Estado onde se realizou a pesquisa ....... 47

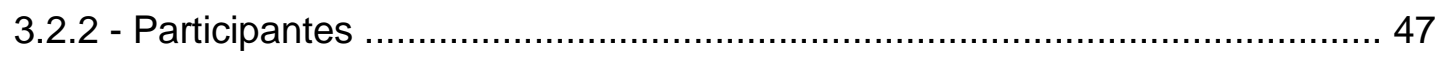

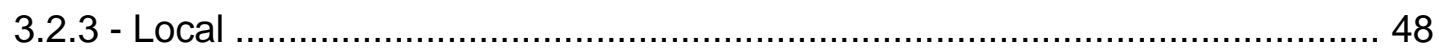

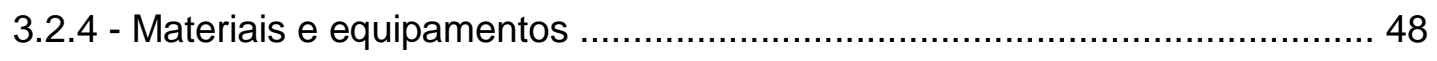

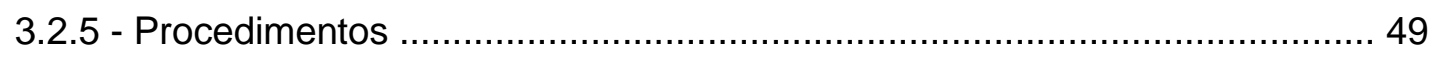

3.2.5.1 - Entrevistas Individuais Semiestruturadas ................................... 49

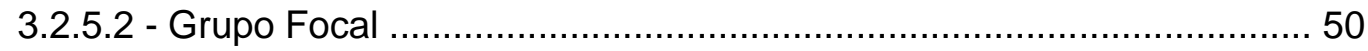

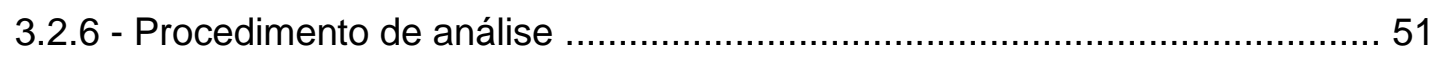

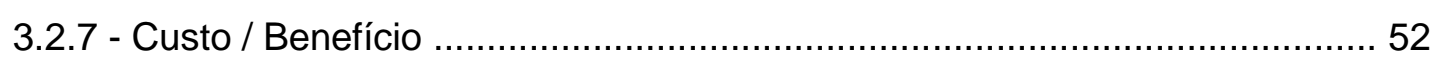

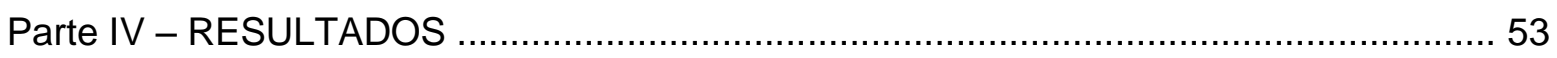

4.1 - Entrevistas Individuais Cadetes …......................................................... 55 


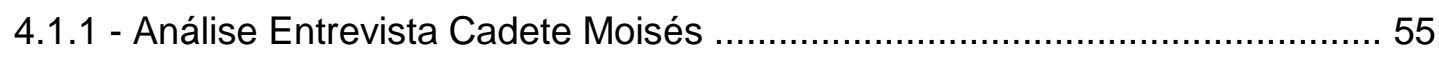

4.1.2 - Análise Entrevista Cadete Ester ....................................................... 67

4.1.3 - Análise Entrevista Cadete Davi ............................................................... 78

4.2 - Análise do Grupo Focal Cadetes .......................................................... 90

4.3 - Entrevistas Individuais Tenentes ......................................................... 108

4.3.1 - Análise Entrevista Tenente Daniel ....................................................... 108

4.3.2 - Análise Entrevista Tenente Suzana .................................................. 122

4.3.3 - Análise Entrevista Tenente Jonas ....................................................... 135

4.4 - Análise do Grupo Focal Tenentes ............................................................. 150

4.5 - Entrevistas Individuais Coordenador e Instrutora CFO ................................... 169

4.5.1 - Análise Entrevista Capitão Rafael - Coordenador do CFO ...................... 169

4.5.2 - Análise Entrevista Capitão Ana - Instrutora do CFO .............................. 179

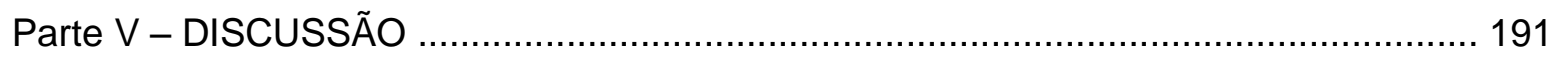

5.1 - Paz, Violência e Conflito: conceitos e significações........................................ 192

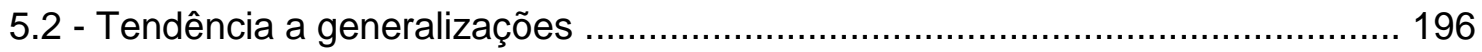

5.3 - Repressão versus Prevenção.................................................................. 198

5.4 - Valores Humanos e Moralidade: posicionamentos diante dos dilemas............ 200

5.4 .1 - De quem é a culpa?"........................................................................... 200

5.4.2 - "Tortura Ética": a fabricação de um conceito ou a noção de que "na prática a teoria é diferente'? ............................................................................... 201

5.5 - Duas faces do militarismo: sedução versus boçalidade.................................... 204

5.6 - A Formação: significações, competição e lealdade ......................................... 205

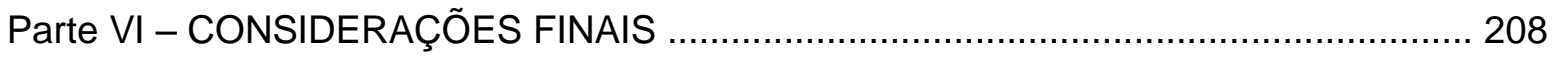

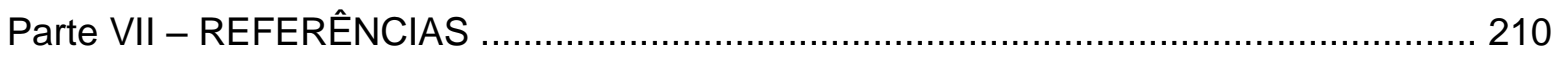

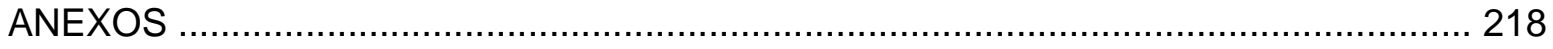

Anexo 1 - Roteiro de Entrevistas Individuais Semiestruturadas - Cadetes e Tenente ... 219

Anexo 2 - Roteiro dos Grupos Focais - Cadetes e Tenentes ....................................... 221

Anexo 3 - Roteiro de Entrevistas Individuais Semiestruturadas - Coordenador ............ 223

Anexo 4 - Roteiro de Entrevistas Individuais Semiestruturadas - Instrutora ................. 225

Anexo 5 - Termo de Ciência e Autorização do Comando da Polícia Militar ................... 227

Anexo 6 - Aprovação Comitê de Ética e Pesquisa .......................................................... 228

Anexo 7 - Termo de Consentimento Livre e Esclarecido .............................................. 231

Anexo 8 - Termo de Cessão e Uso de Imagem ......................................................... 233

Anexo 9 - Imagens utilizadas nas Entrevistas Individuais com os Cadetes e Tenentes 234 


\section{APRESENTAÇÃO}

Analisar os padrões de relação e interação entre as pessoas, identificando os componentes e o desenvolvimento destes padrões, é tarefa essencial da Psicologia. Compreender como as pessoas interagem de forma agressiva e violenta, ou de maneira cooperativa e construtiva demanda investigar os fatores que mediam o comportamento humano e as interações sociais que vão se constituindo ao longo dos processos de socialização na família, nas escolas, e nos mais variados setores da sociedade.

O estudo do desenvolvimento humano, área importante da Psicologia, vem avançando e, na abordagem sociocultural aqui adotada, privilegia os processos em detrimento dos resultados das mudanças desenvolvimentais. $O$ desenvolvimento, portanto, tem como características principais a dinamicidade, continuidades e descontinuidades e não segue estágios obrigatórios, o que possibilita novas perspectivas e alternativas para os sujeitos em seus contextos culturais (Branco, 2009).

Nesta pesquisa o desenvolvimento humano é concebido a partir de uma perspectiva cultural semiótica e coconstrutiva, buscando compreender como são construídos conceitos, valores e posicionamentos sobre a temática da violência e da paz. Este tema vem sendo investigado pela autora desde o Mestrado (Moreira, 2011), e tem central relevância no contexto de suas atividades profissionais dentro da instituição da Polícia Militar como psicóloga.

Na perspectiva da Psicologia Cultural, o desenvolvimento humano é entendido como processos de mudanças que ocorrem ao longo das interações entre os indivíduos e os contextos socioculturais nos quais estão inseridos, especialmente por meio da experiência ativa e de suas características pessoais (Bruner, 2001). Valsiner $(2012,2014)$ tem estudado os processos de desenvolvimento humano ancorados em sistemas semióticos, com forte influência de aspectos afetivos que são criados e transformados nos contextos socioculturais. Segundo este autor, as práticas sociais afetam as significações e construções simbólicas da pessoa em uma relação bidirecional.

Pode-se afirmar que um dos principais objetivos da Psicologia do Desenvolvimento é o estudo das mudanças na trajetória de vida dos indivíduos (Zittoun, 2009). A mudança e o desenvolvimento surgem em um espaço de tensões entre as significações partilhadas das coisas e o sentido único, e sempre podem se reinventar a partir dos significados que as pessoas Ihes atribuem. (Zittoun, Mirza e Perret-Clermont, 2007).

Diante da natureza complexa e dinâmica do ser humano, nesta tese propomos uma investigação empírica e uma reflexão teórica que perpassa por conceitos fundamentais do desenvolvimento humano, como a construção de valores sociais, as 
práticas dele decorrentes e também geradoras destes valores, focalizando especialmente a questão da Violência e da Paz.

As ações práticas que envolvem paz e violência decorrem da construção sociocultural desses dois conceitos e, ao mesmo tempo, tais práticas contribuem ainda mais para a consolidação das crenças e valores que estão em sua origem. A maneira como dificuldades e conflitos são conduzidos pode gerar a organização de sistemas em que a paz, enquanto processo, emerge e pode ser promovida. Ou, então, em que a violência venha a prevalecer. Dessa forma, práticas culturais, ações, emoções e relacionamentos podem favorecer sistemas semióticos promotores de paz ou de violência (Rengifo-Herrera, 2014).

A violência é frequentemente associada à ideia de agressão, onde o limite estabelecido pela necessidade de respeito e consideração pelos outros é ultrapassado, seja em nível pessoal ou institucional. Agressão e violência impedem, ou dificultam, o desenvolvimento individual e social e, ao se tornarem uma prática cultural corriqueira, acabam por gerar significados no contexto sociocultural que certamente criam problemas para a promoção da paz.

A paz, por sua vez, é concebida como um conceito tipicamente processual - está sempre em processo de construção - caracterizado pela convivência cooperativa entre seres humanos em geral, ou seja, é compreendida como um conceito positivo e não como a simples ausência de conflitos ou enfrentamentos. Possui uma vertente dialética e construtiva, estando intrinsecamente relacionada à resolução não violenta de conflitos, por meio da educação, do diálogo e da cooperação (Jares, 2002). Guimarães (2005) concorda com essa visão e propõe uma noção de paz muito mais processual, multicultural e dialógica do que um estado de espírito, e afirma que a paz deve ser pautada em ações concretas e não em ideais.

A Cultura da Paz é uma cultura positiva, e não pode ser definida pela simples ausência de conflitos ou violência; mas também não se empenha em promover o conformismo entre as pessoas. Ela considera que os conflitos e divergências são necessários ao jogo democrático, e devem ser resolvidos mediante negociações construtivas, e não de forma violenta (Branco, Manzini \& Palmieri, 2012). Nesta pesquisa, discutimos a questão do conflito construtivo e destrutivo, sendo essa questão geradora de violências especialmente destacada diante da função específica da instituição estudada. Nessa perspectiva, analisaremos os processos semióticos que envolvem construção de valores e virtudes, bem como os elementos que favorecem a construção e promoção da Cultura de Paz no contexto específico.

Tais reflexões ampliam as possibilidades de discussão sobre o tema proposto, partindo do princípio que as práticas culturais, bem como valores e virtudes, não são 
estáticos, mas podem ser (re) construídos a qualquer momento, dependendo da motivação para isso. Para tanto, torna-se essencial considerar que essa construção é fruto de uma interação dialética entre indivíduo e cultura, propiciando uma transformação que culmine em um movimento pró-ativo e dinâmico para prevenir e combater a violência.

Fazendo um recorte para um contexto específico, escolhemos a Polícia Militar (PM) do Estado X como campo de pesquisa, por suas peculiaridades de atuação social, a qual é por vezes preventiva e, por vezes, coerciva, e também pelo fato de ser a PM o campo de trabalho da pesquisadora.

A violência urbana em nosso país é um caso grave, que tem sido foco de diversificados estudos acadêmicos, bem como de análises e implantações de políticas públicas, visando sua diminuição. A Polícia Militar figura, nesse contexto, como uma instituição social que presta serviço à sociedade, baseada no lema "Servir e Proteger".

A instituição PM vem consolidando, ao longo dos anos, mudanças em sua filosofia de trabalho voltada para a inter-relação com a sociedade, visando atender as demandas emergentes da sociedade contemporânea. Foi assim que surgiu a Polícia Comunitária, que é uma filosofia de trabalho fundamentada, principalmente, na parceria entre a população e as instituições de Segurança Pública e Defesa Social. Ela propõe que os policiais sejam preparados para lidarem com os problemas cotidianos dos cidadãos comuns, de forma particularmente preventiva, e não somente coerciva, como há anos se postulava.

Nosso interesse em aprofundar conhecimentos sobre conceitos, valores e posicionamentos relacionados à violência e à paz no contexto da Polícia Militar do Estado $X$, surgiu com base nas seguintes questões: Como o Curso de Formação de Oficiais (CFO) e a prática profissional dos oficiais da PM promovem conceitos e valores específicos relacionados à violência e à paz? Como os oficiais da PM desenvolvem seus posicionamentos e ações relativas às questões de violência e à construção de uma Cultura de Paz? O que pode ser feito para estimular uma formação profissional capaz de transformar os oficiais em agentes promotores da paz?

Temos como pressuposto que "A Polícia Militar também educa" ao construir, por meio da atuação policial nas ruas, valores e práticas que contribuam para uma Cultura de Paz. Faz-se necessário, no entanto, não reduzir a questão da paz a uma simples "paz de espírito" ou "paz interior", pois é principalmente a paz social que nos interessa. Esta não é uma paz feita de conformismo ou repressão, e não é uma paz conquistada apenas em nível individual. Trata-se aqui de uma paz social e relacional, que implica na aceitação da diversidade, das divergências e na mediação ativa para a resolução pacífica de conflitos.

Portanto, analisar a motivação de ações que envolvem paz ou violência, entender os conceitos, significações e transformações a partir da cultura militar, e criar estratégias 
para observar e analisar questões relacionadas a este tema, tudo isso exige cuidadosa investigação. Em consonância com esse contexto, encontramos o complexo cenário em que se desenvolvem as ações policiais militares. Por um lado temos uma estrutura hierárquica onde as tradições são cultivadas e mantidas ao longo do processo formativo. Por outro, temos uma sociedade democrática que exige a evolução de todos os seus segmentos, incluindo a Segurança Pública. Portanto, o desafio é enorme!

A partir desta pesquisa, pretendemos obter informações e dados que possibilitem construções teóricas e práticas que favoreçam a compreensão do desenvolvimento de valores sociais, gerando novas formas de investigar e compreender os conceitos, valores e posicionamentos de oficiais em formação (Cadetes) e recém-formados (Tenentes). Ressaltamos que nosso objetivo é buscar a identificação de processos ligados a sociogênese dos valores humanos e, assim, poder contribuir para a uma discussão ampla que possibilite o envolvimento da Polícia Militar como um todo, consequentemente atingindo a sociedade de forma construtiva.

Para tanto, torna-se necessário compreender as práticas e concepções presentes na vida dos policiais militares, em especial na sua formação, para pensar na sua atuação diante de situações de conflito, a qual poderá potencialmente envolver ações construtivas ou violentas. Estes seriam conhecimentos importantes para promover um aprimoramento concreto da prestação de serviços da instituição militar, sempre de forma articulada com os demais setores da sociedade.

A realidade atual da Polícia Militar no Brasil tem por objetivo aperfeiçoar a qualidade das relações entre o policial e a sociedade, de maneira que este seja um mediador de conflitos. A realização deste trabalho deverá, também, contribuir para identificar e analisar o impacto do CFO e da experiência profissional dos Oficiais do Quadro Operacional da Polícia Militar (QOPM) do Estado X na construção de conceitos, valores e expectativas profissionais relacionadas à violência e à paz. Entendemos que as práticas culturais vigentes em um determinado contexto, como a Polícia Militar, podem ser repensadas e, a partir daí, gerar práticas promotoras de valores e comportamentos pró-sociais e cooperativos, fundamentos da Cultura de Paz no contexto da sociedade.

Consideramos, como relevância para a realização deste trabalho, a escassez de estudos científicos no contexto da Polícia Militar, especialmente na perspectiva da Psicologia do Desenvolvimento. Vale a pena salientar que estudos envolvendo a formação do Oficial da PM são praticamente inexistentes, sendo que esta pesquisa se situa nessa lacuna.

Diante da complexidade do fenômeno que nos propomos a estudar, este trabalho se dispõe, também, a contribuir para a formulação de um referencial teórico e desenvolver conhecimentos capazes de fornecer subsídios para uma metodologia de 
capacitação profissional a ser utilizada no Curso de Formação de Oficiais, no sentido destes se tornarem agentes multiplicadores da Cultura de Paz na sociedade. Pretendemos, com isto, contribuir para programas e políticas públicas na área de Segurança Pública que venham ampliar a atuação preventiva dos policiais militares no sentido de viver e educar para uma sociedade em paz.

A tese foi estruturada em sete partes. Na fundamentação teórica (primeira parte), iniciamos com o Capítulo 1, onde fazemos uma apresentação dos principais pressupostos e fundamentos teóricos da Psicologia Cultural, na perspectiva sociocultural construtivista e semiótico cultural, No Capítulo 2, discutimos a temática da Violência e da Paz, levantando e analisando aspectos teórico-conceituais fundamentais à investigação proposta nesta pesquisa. No Capítulo 3, trazemos alguns fundamentos da estrutura, organização e objetivos da Polícia Militar e sua cultura institucional, apresentando os pressupostos mais relevantes sobre os quais se baseia esta instituição.

$\mathrm{Na}$ segunda parte do trabalho, trazemos os objetivos gerais e específicos. $\mathrm{Na}$ terceira parte, são apresentadas algumas reflexões metodológicas considerando o processo de coconstrução do conhecimento científico no campo do desenvolvimento humano, e, em seguida, explicitando o método de investigação, os participantes da pesquisa e os procedimentos adotados.

$\mathrm{Na}$ quarta parte, apresentamos os resultados da pesquisa de campo, seguido das análises construtivo-interpretativas das narrativas apresentadas pelos participantes. A ordem de apresentação dos resultados foi estabelecida na seguinte ordem: Entrevistas individuais com os Cadetes (alunos do CFO); Grupo Focal - Cadetes; Entrevistas individuais com os Tenentes (com dois anos de formados); Grupo Focal - Tenentes; Entrevista individual com o Coordenador do CFO; e a Entrevista individual com uma instrutora do CFO.

$\mathrm{Na}$ quinta parte fazemos a discussão dos resultados da pesquisa, destacando os principais pontos e aspectos analisados. Na sexta parte, trazemos nossas considerações finais; e na sétima e última parte, estão as referências bibliográficas, seguidas dos anexos contendo os documentos e instrumentos utilizados nesta pesquisa.

Nosso principal objetivo, com este trabalho, foi identificar, analisar e discutir a formação de conceitos, crenças, valores e posicionamentos dos participantes em relação a questões referentes à violência e à paz no contexto da Polícia Militar, tendo em vista o desenvolvimento de práticas orientadas para a formação de oficiais do Quadro Operacional da Polícia Militar como agentes na construção da paz. 


\section{PARTE I}

\section{FUNDAMENTAÇÃO TEÓRICA}

A fundamentação teórica está organizada em três capítulos que buscam apresentar e refletir os conceitos teóricos que embasaram as análises dessa pesquisa. No Capítulo 1, apresentamos o contexto teórico do Desenvolvimento Humano e Cultura, perpassando por alguns conceitos fundamentais da Psicologia Cultura, na perspectiva Semiótico-Cultural Construtivista (Branco, 2009, 2012; Valsiner, 2012, 2014). No Capítulo 2, discutimos a temática da Violência e Paz, levantando e analisando aspectos teóricoconceituais fundamentais à investigação proposta nesta pesquisa. No Capítulo 3, trazemos alguns fundamentos da estrutura, organização e objetivos da Polícia Militar e sua cultura institucional, apresentando os pressupostos mais relevantes sobre os quais se baseia esta instituição.

\section{CAPÍTULO 1 \\ DESENVOLVIMENTO HUMANO E CULTURA}

\section{1 - Fundamentos da Psicologia Cultural na Perspectiva Semiótico-Cultural Construtivista}

O desenvolvimento humano constitui-se em processo dinâmico e contínuo exigindo, ao longo da história da psicologia, cada vez mais estudos e investigação. A consideração da cultura e a importância das interações sociais destacada pela escola histórico-cultural de Vygotsky (1989) têm levado a quebra dos paradigmas universalistas que buscam criar conhecimentos descontextualizados e, orientado o estudo do desenvolvimento humano no sentido de destacar, analisar e discutir sobre a complexidade do ser humano sob uma visão sistêmica de todos os processos envolvidos.

Assim, estudar, refletir e compreender o ser humano em desenvolvimento envolve uma gama de fatores que se entrelaçam para constituí-lo com tal. Estes, são mobilizados e construídos ao longo da trajetória dos sujeitos e, em particular, através dos processos de socialização na família, nas escolas, e nos mais variados setores e instituições da sociedade (Valsiner, 2012; 2014).

O desenvolvimento humano é aqui entendido como um processo de mudanças que ocorre ao longo das interações entre os indivíduos e os contextos socioculturais nos quais estão inseridos, por meio de suas experiências pessoais culturalmente canalizadas, mas, ao mesmo tempo, únicas e singulares (Branco, 2012; Valsiner, 2012, 2014). Para os propósitos deste trabalho, consideramos o desenvolvimento humano a partir de uma ótica 
prospectiva, privilegiando os processos e as mudanças ocorridos nos indivíduos através de suas interações e reconstruções com o ambiente (Sifuentes, Dessen \& Lopes de Oliveira, 2007), e considerando o papel da antecipação do futuro que caracteriza a esse processo (Valsiner, 2014).

$\mathrm{Na}$ sociedade em geral ou em contextos específicos como, em determinados grupos ou instituições, as interações e relações sociais produzem efeitos muito significativos no sentido da construção de crenças e valores e da atuação de seus membros no contexto das práticas culturais. É nesse contexto de interações sociais que a comunicação e a metacomunicação desempenham importante papel coconstrutivo no desenvolvimento da pessoa, suas características individuais e processos de significação (Branco \& Lopes-de Oliveira, 2012; Branco \& Valsiner, 2004; Valsiner, 2005; 2012, 2014).

Com base no pressuposto que o ser humano, criança ou adulto, está em constante desenvolvimento, Rogoff (2005) concebe o desenvolvimento como a transformação da participação das pessoas em atividades socioculturais contínuas que se modificam com o envolvimento de indivíduos em sucessivas gerações. A autora refere-se à teoria histórico-cultural de Vygotsky, reafirmando que "os esforços individuais não são separados dos tipos de atividades nos quais as pessoas se envolvem e dos tipos de instituições de que fazem parte" (p. 50).

Entende-se, assim, que o desenvolvimento humano necessita ser estudado a partir de uma visão ampliada, envolvendo todas as dimensões da pessoa e dos posicionamentos que assumem em seu contexto sociocultural. Pensar aqui em práticas institucionais e na modalidade de participação dos membros da instituição social pode, portanto, ser um caminho produtivo para implementar transformação e desenvolvimento, seja em nível pessoal ou institucional, tema de interesse deste estudo.

Na perspectiva sociogenética estudada e desenvolvida por Vygotsky (1989), o ser humano se constitui sócio-historicamente através de um processo no qual a cultura é parte essencial da construção das funções psicológicas superiores. Para o autor, tais funções manifestam-se primeiramente no nível das interações sociais, para depois tornarem-se funções individuais internalizadas. Em uma perspectiva dialógica, o indivíduo transforma e é transformado pelo seu contexto cultural ao mesmo tempo. De acordo com a visão enfatizada por Vygotsky (1989), os processos de desenvolvimento humano é algo que acontece de fora (do âmbito social) para dentro (indivíduo). Branco e Mettel (1995) compartilham essa ideia e afirmam que ao estudar a interação social é imprescindível levar em consideração contexto histórico-cultural no interior do qual se dão as interações. Não apenas em seu sentido mais amplo, social e institucional, mas também no sentido dos significados, valores, regras e expectativas que estão a cada instante sendo negociados no interior de cada grupo específico. 
Bruner (1997) considera que a Psicologia Cultural não está focada em comportamentos, mas em ações situadas e significadas dentro de um cenário cultural, no qual as intenções dos participantes são de grande importância. Nessa orientação, dizer e fazer constituem uma unidade inseparável, pois os processos de significação mediados pela cultura tornam-se públicos quando compartilhados. $O$ autor coloca, ainda, que viver em sociedade é compartilhar interpretações e significados de forma pública para manter e permitir o desenvolvimento da própria cultura e daqueles que a constituem (Bruner, 1997).

A Psicologia Cultural é relativamente recente na Psicologia, considerando as potencialidades individuais e o contexto social como partes fundamentais do processo de mútua construção da pessoa e da cultura ao longo do tempo (Valsiner, 2014). Estuda modelos teóricos de compreensão do ser humano, baseados em uma visão de sujeito que se transforma constantemente em interação com o contexto sócio-histórico-cultural também em desenvolvimento, mas o sujeito não é mero produto da cultura, ele é um sujeito ativo, coconstrutivo e atuante em seu próprio desenvolvimento (Madureira \& Branco, 2005; Valsiner, 2012). Nessa perspectiva, a cultura é vista, portanto, como fator constitutivo deste sujeito ativo e construtivo.

Fora dos contextos culturais específicos em que o sujeito está inserido não é possível considerar as funções psicológicas tipicamente humanas, como a cognição, a memória, o pensamento abstrato e a autoconsciência (Valsiner, 2012). A Psicologia Cultural, portanto, oferece uma proposta teórico-metodológica que destaca a centralidade da coconstrução de significados culturais e subjetivos que são criados através dos processos de comunicação e metacomunicação entre as pessoas nos mais diversos contextos (Branco, 2006, 2009; Valsiner, 2012).

Adotar uma perspectiva cultural de orientação coconstrutivista semiótico-cultural implica, também, assumir um olhar sistêmico (Thelen \& Smith, 1998) e interdisciplinar, em que cabe à psicologia, em articulação com as demais ciências, dedicar-se ao estudo das relações entre as dinâmicas específicas engendradas no contexto das práticas socioculturais e na ontogênese do sujeito (Branco, 2006). Branco e Lopes de Oliveira (2012) afirmam, em resumo, que:

"a abordagem cultural detém como principais especificidades pressupor um sujeito ativo e considerar o caráter bidirecional das ações humanas ocorridas em contextos sociais concretos, em que sujeito e contexto se constituem e transformam mutuamente" (p. 12).

Outro aspecto fundamental a ser considerado é a questão do tempo. Valsiner (1998, 2012, 2014) e Sato, Hidaka e Fukuda (2009) propõem que a irreversibilidade do tempo é sempre associada à emergência de novos conceitos e trajetórias de 
desenvolvimento. Deve-se considerar que a organização temporal do fenômeno psicológico é um fator que elucida a compreensão do desenvolvimento humano, observando a sequência de eventos durante um determinado tempo. A partir disso, devese procurar compreender como novos eventos e significações decorrem de eventos e significações anteriores que influenciam as ações humanas. Assim, o desenvolvimento humano se dá como um processo de contínuos saltos qualitativos, caracterizado pela emergência de funções psicológicas superiores e pela transformação que geram novas funções e padrões psicológicos ao longo do tempo.

Uma consideração de ordem metodológica é, também, apropriada ao discutirmos as contribuições da abordagem cultural. Esta destaca, também, a dinâmica dialética dos processos de desenvolvimento no tempo real, do "aqui e agora", enfatiza o potencial metodológico de estudos microgenéticos para desvendar as estratégias e os mecanismos envolvidos nos processos de internalização das mensagens culturais e consequente coconstrução de valores (Valsiner, 2014). A disposição em refinar os significados das interações constitui um importante desafio metodológico a ser enfrentado pelos pesquisadores, e o estudo dos valores demandam essa forma de análise, como bem demonstra o trabalho de Rengifo-Herrera (2014) sobre o desenvolvimento de valores de violência em crianças, em que observa suas interações sociais em um contexto lúdico e, depois, nas entrevistas sobre a experiência vivida.

Branco $(2006,2012)$ afirma que os estudos microgenéticos são necessários para que a noção de sociogênese não se constitua apenas em um conceito genérico, com limitado valor heurístico para a compreensão da pluralidade e interdependência dos processos envolvidos no desenvolvimento humano. Considerar um processo genérico de "sociogênese" não identifica os aspectos e características relevantes dos processos microgenéticos que são apenas observáveis e passíveis de análise no contexto das interações concretas, no "aqui e agora", entre os indivíduos. Inserir análises microgenéticas dos processos psicológicos, portanto, tem contribuído muito para uma melhor compreensão do desenvolvimento humano (Salvatore, 2012, 2013).

Em continuação, analisamos especificamente o papel da cultura nos processos de desenvolvimento humano.

\section{A Cultura}

Muito vem se discutindo a respeito da importância ou influência da cultura no desenvolvimento humano, o que tem produzido pesquisas e grandes avanços teóricos e metodológicos no campo da Psicologia Cultural. No entanto, vale destacar que o conceito de cultura não é homogêneo ao longo da vasta literatura produzida sobre o tema (Jahoda, 2012) e, portanto, para não correr o risco de uma incompatibilidade lógica, o 
termo cultura é aplicado, no contexto deste trabalho, como uma construção social complexa. Os processos de significação são desenvolvidos de diferentes formas, considerando os significados compartilhados pelo contexto sociocultural e os sentidos subjetivos do sujeito, que se constroem mediante diálogos interpessoais e intrapessoais (Branco, 2012; Valsiner, 2014).

É fato que nos últimos cinquenta anos o estudo da cultura vem ganhando espaço no âmbito da Psicologia do Desenvolvimento. Na visão de Zittoun, Mirza e PerretClermont (2007), "o lugar da 'cultura' remete às relações entre 'significações coletivas' e 'sentido pessoal' do conhecimento e da atividade" (p. 67). O que nos possibilita considerar fatores como a ação humana e objetos que mediam o comportamento, para melhor compreender o papel da cultura.

O grande antropólogo Malinowski (1944) compreende a cultura como um composto que integra e coordena partes de instituições autônomas. Ela é integrada em uma série de princípios que fazem referência à comunidade, à contiguidade no espaço relacionadas à cooperação, à especialização em atividades e, por último, ao uso de poder na organização política. "Cada cultura deve sua completude e autossuficiência ao fato de que satisfaça toda a gama de necessidades básicas, instrumentais e integrativas do ser humano" (p. 40).

Ressaltando a importância do tema, Bruner (2001) propõe que uma cultura configure tanto um fórum para negociar e renegociar significados e explicar ações, como um conjunto de regras ou especificações para a ação. Em outro trabalho, o autor relata que "o divisor na evolução humana foi cruzado quando a cultura se tornou o fator principal para dar forma às mentes daqueles que viviam sob sua influência" (Bruner, 1997, p. 22). Sendo assim, a participação do homem na cultura, e a realização de seus processos mentais por meio dela, são imprescindíveis para seu desenvolvimento.

Rogoff (2005) afirma que, na perspectiva sociocultural:

"a cultura não é uma entidade que influencia os indivíduos. Em lugar disso, as pessoas contribuem para a criação de processos culturais e estes contribuem para a criação de pessoas. Dessa forma, os processos individuais e culturais são mutuamente constitutivos e não definidos separadamente" (p. 51).

Nesse sentido, a cultura é vista como um sistema aberto, onde o desenvolvimento acontece entre sistemas que se influenciam mutuamente. Como bem expressa Valsiner (2012), a "cultura 'pertence ao' sistema psicológico individual e desempenha um papel funcional dentro dele" (p. 28). Por isso, o fenômeno do desenvolvimento exige um estudo sistêmico e multidisciplinar, onde o objeto do estudo tem uma relação interdependente com o seu ambiente, tornando-se impossível dissociar sujeito e objeto do conhecimento na perspectiva da Psicologia Cultural. 
Como afirma Bruner (2001), a cultura não é uma entidade estática e não determina linearmente o desenvolvimento individual. É justamente nesta direção que Valsiner (1998) propõe o conceito de separação inclusiva, que pretende assegurar a diferença estrutural entre o indivíduo e o contexto sociocultural, resguardando o caráter de interdependência sistêmica entre ambos. Portanto, o indivíduo não é independente do contexto cultural em que se encontra inserido, mas também não é mero reflexo deste contexto. O indivíduo mantém uma relação de relativa autonomia e de constituição recíproca com o contexto. A ênfase no papel ativo, consciente e intencional do sujeito psicológico está relacionada a uma concepção dinâmica da cultura. A cultura engloba tanto a dimensão material, cristalizada nos produtos culturais, como a dimensão simbólica, fluida, presente nos processos culturais de significação do mundo e de si mesma (Madureira \& Branco, 2005).

Rosa e González (2012) concebem a cultura como um conjunto de práticas, hábitos e marcas que possibilitam as pessoas terem significativas experiências individuais: "A cultura provê artefatos e papéis, símbolos e linguagens, práticas e normas, instituições e leis" (p. 10). Os autores postulam que esses elementos compartilhados tornam possível a emergência de alguns significados comuns e o desenvolvimento de algumas classes de intersubjetividade, configurando direções a serem alcançadas e uma identidade social e pessoal a ser construída. "A cultura transforma um grupo em uma comunidade e constrói a individualidade humana" (p. 10).

$\mathrm{Na}$ perspectiva de Valsiner (2012) existe uma diferença significativa entre cultura pessoal e cultura coletiva. Segundo ele, a cultura coletiva é fundamental para o desenvolvimento do sistema de valores e crenças que orientam as ações do ser humano, promovendo certas formas de conduta social. Muitos estudiosos argumentam que os significados compartilhados da cultura coletiva, entre eles normas e regras sociais, acabam por conduzir as práticas sociais diárias. A cultura pessoal, por sua vez, é constituída pelos significados que cada indivíduo desenvolve ao internalizar, de maneira ativa, as mensagens culturais, e estes significados acabam por ter um impacto importante sobre o seu comportamento. Essas duas formas de cultura, individual e coletiva interagem dialeticamente proporcionando o desenvolvimento e a relativa adaptação do indivíduo ao seu contexto sociocultural. Em uma perspectiva dialógica, cada vez mais assumida no campo da psicologia, o indivíduo transforma e é transformado por sua cultura, concomitantemente (Valsiner, 2012).

Nesse mesmo sentido, ao discutir a questão dos valores, Branco (2012) ressalta que a cultura coletiva é importante para o desenvolvimento do sistema de valores e crenças do ser humano, pois estes promovem certas formas de conduta e práticas sociais. Também Valsiner (2012) postula que os significados compartilhados da cultura 
coletiva, entre eles normas e regras sociais, acabam por conduzir às práticas culturais. A cultura pessoal, em síntese, é constituída pelos significados que cada indivíduo internaliza e que regem seu comportamento, crenças e valores.

O modelo bidirecional proposto por Valsiner (2003) reconhece que todos os membros de determinada cultura estejam transformando ativamente as mensagens culturais que estão recebendo. Transformam, mas, ao mesmo tempo, são transformados pelos contextos culturais, através do que ele denomina como canalização cultural (mensagens e sugestões sociais de caráter redundante). Assim, as práticas sociais afetam as significações e construções simbólicas da pessoa em uma relação bidirecional, fazendo com que os processos individuais e culturais sejam mutuamente constitutivos e não definidos isoladamente.

De acordo com Sifuentes, Dessen e Lopes de Oliveira (2007) a participação do indivíduo na construção do mundo social possibilita a emergência de diferentes significações, que podem transformar o curso de seu desenvolvimento, assim como afetar a dinâmica do meio sociocultural em que está inserido. Suas ideias, assim, corroboram o posicionamento de Valsiner (2003) sobre a relação bidirecional.

$\mathrm{Na}$ psicologia do desenvolvimento, a discussão teórica e conceitual que envolve os processos de socialização vem sendo analisada, segundo Palmieri e Branco (2004), no nível das ações ou comportamentos observáveis, isto é, estudos têm sido realizados para investigar a ocorrência de comportamentos caracterizados como pró ou antissociais. De uma forma geral, a maioria dos autores que Palmieri e Branco discutiram concorda que os comportamentos pró-sociais são aqueles que representam ações ou atividades consideradas como socialmente construtivas, visando atender às necessidades e ao bem-estar de outras pessoas, como, por exemplo, o altruísmo, a generosidade, os sentimentos de empatia e simpatia etc. No caso da cooperação, que atende os interesses do sujeito e do outro com quem interage, esta seria uma modalidade específica de prossociabilidade. De maneira similar, práticas e valores antissociais podem conduzir à violência e a hostilidade (Banco, Palmieri \& Gomes Pinto, 2012).

Esses argumentos consolidam, portanto, a ideia de que ações e interações voltadas para a paz podem ser desenvolvidas e dependem tanto dos sujeitos quanto das instituições envolvidas no processo. Nesse sentido, as instituições têm fundamental importância na construção da Cultura de Paz, uma vez que compõem a rede de relações e interações socioculturais de seus membros, desempenhando um importante papel social. Dessa forma, a instituição também precisa estar aberta às mudanças demandadas pela sociedade contemporânea.

Outro conceito que vale a pena discutir refere-se à canalização cultural no processo de desenvolvimento do sujeito. O conceito de canalização cultural é 
amplamente utilizado na Psicologia Cultural, sendo definido como um mecanismo geral de desenvolvimento, através de um processo gradual, onde as sugestões sociais explícitas e implícitas orientam as interações conduzindo o desenvolvimento para uma direção determinada (Valsiner, Branco e Dantas, 1997). Segundo a perspectiva semiótico-cultural construtivista, a canalização cultural ocorre a partir destas sugestões sociais, mediante as quais a pessoa em desenvolvimento é orientada ao longo de sua trajetória de vida, partindo da microgênese à ontogênese (Branco \& Valsiner 2012).

Nesse sentido, a pessoa encontra-se constantemente construindo padrões a partir de sua interação com o meio, que favorece a internalização de certas mensagens culturais, ao mesmo tempo em que outras são bloqueadas. A canalização cultural é, portanto, um elemento-chave na análise das vivências dos indivíduos nos diferentes contextos e levanta explicações sobre como se desenvolvem as orientações para crenças e valores de pessoas e grupos. Essa canalização ocorre ao longo da trajetória histórica da pessoa e considera o papel ativo do sujeito, o que permite que essas sugestões sejam reelaboradas mediante o processo de internalização. Branco, Manzini e Palmieri (2012) definem canalização cultural como "o processo, segundo o qual, a cultura promove o desenvolvimento em determinadas direções por meio de sugestões sociais implícitas (indiretas) ou explicitas (diretas) (p. 96)". Em resumo, a canalização cultural está estreitamente relacionada aos sistemas de crenças e valores que são transformados ou coconstruídos pelo indivíduo mediante os processos de internalização/externalização (Branco \& Valsiner 2012).

Staub (2003) afirma a importância da cultura e dos símbolos culturais, os quais facilitam ou dificultam a linguagem dos grupos sociais, e ditam a necessidade de se incorporar atitudes e percepções culturais dentro dos modelos e teorias da análise e resolução de conflitos.

Analisar e discutir a questão dos conflitos construtivo e destrutivo (Valsiner \& Cairns, 1992) envolve, por sua vez, analisar e discutir as questões da violência e da paz, especialmente relacionadas à função da Polícia Militar. Com base em uma perspectiva teórica de natureza complexa e dinâmica, entretanto, vale ressaltar que os conflitos considerados construtivos e destrutivos não são necessariamente antagônicos, sendo possível, por exemplo, que conflitos potencialmente destrutivos sejam transformados em construtivos pela mediação adequada dos profissionais que participam do processo de confronto em questão. 


\section{2 - Sociogênese dos Valores Sociais: A Constituição Mútua de Práticas Culturais e Processos de Significação}

As Ciências Humanas e Sociais vêm, ao longo tempo, se debruçando no estudo das práticas culturais nas mais diversas sociedades do planeta. O grande antropólogo Geertz (1989) define o conceito de cultura como essencialmente semiótico. Este autor concebe o homem como um animal amarrado a teias de significados que ele mesmo teceu, e assume o estudo da cultura, não como uma ciência experimental em busca de leis, mas como uma ciência interpretativa à procura de significados. "É justamente uma explicação que eu procuro, ao construir expressões sociais enigmáticas em sua superfície" (p. 15), pondera o autor.

Bruner (1997), por sua vez, enfatiza que as ações sociais funcionam como mediador semiótico nos processos de desenvolvimento humano e têm fundamental papel para a transformação de pessoas e instituições. Assim sendo, as práticas socioculturais vigentes no comportamento individual ou coletivo, vão sendo constituídas como tal durante o próprio processo de desenvolvimento de cada pessoa, possibilitando a aquisição de significados subjetivos. Cole e Cole (2003) também defendem que as ações concretas de cada ser humano estão "emolduradas" na cultura: possuem seu lugar, mas apenas podem ser entendidas a partir de um contexto. Além disso, é importante considerar o principal fundamento da Psicologia Cultural: as práticas e ações, de um lado, e os processos de significação - como crenças e valores - que se constituem mutuamente (Branco, 2012, Valsiner, 2012).

Além disso, Zittoun, Mirza e Perret-Clermont (2007) concordam que a significação social partilhada de algumas ações é mediada por objetos. Observam, também, que o sentido mais pessoal e privado que estes objetos podem adquirir se ancora na história pessoal e na subjetividade de cada um, além de sua sociogênese na história da cultura coletiva.

Em termos sociogenéticos, no entanto, como práticas e valores da cultura são trazidos para o campo intrapsíquico? Valsiner $(2007,2014)$ reflete que os significados culturais são construídos por meio de processos de internalização e externalização. São processos complementares que pressupõem transformações constantes, tanto em nível individual quanto coletivo, sendo aqui entendidos como parte essencial de uma perspectiva cultural. Contextos e sujeito ativo, mediante processos de internalização/externalização de mensagens culturais, acabam gerando reguladores externos e intrapsíquicos para o desenvolvimento humano no que se refere à construção de valores, crenças, práticas e tradições (Valsiner, 2012).

A dimensão semiótica dos processos de significação encontra-se na base constitutiva e fundamental dos múltiplos aspectos da condição humana. Ou seja, "os 
processos de significação se constituem a partir de complexas interações entre linguagem, cognição, afeto e motivação, dimensões que se conjugam de forma sistêmica na contínua produção de significados que caracterizam a experiência de significação" (Branco, 2006, p. 44). A linguagem também ganha análise na obra de Valsiner (2012), "a linguagem que a pessoa utiliza para interagir dentro de sua sociedade é uma ferramenta semiótica no sistema intrapsíquico da pessoa e orienta os modos pelos quais ela pensa, sente e articula sua fala" (pág. 28)

Valsiner (2012) argumenta que a mediação semiótica é também uma ferramenta utilizada pelas instituições sociais no âmbito das ações orientadas por metas, na tentativa de regular as funções psicológicas, tanto inter quanto intrapessoais. "As instituições estabelecem regras sociais para interação, monitoram sua manutenção e colocam expectativas para que a atividade e a interação situadas conduzam à transformação intrapsicológica dos sistemas culturais pessoais" (Valsiner, 2012, p. 30).

O papel dos signos culturais como mediadores do desenvolvimento psicológico tem sido uma temática bastante investigada no âmbito da Psicologia Cultural nos últimos anos. Sem dúvida, a contribuição de Valsiner $(2012,2014)$ tem sido fundamental para a discussão de questões semióticas e sua participação na formação do sujeito. O autor propõe que os significados (coletivos e individuais) são organizados a partir da interação social, sendo que os campos afetivo-semióticos orientam as ações para o futuro e também constituem a base da organização de crenças, motivações e valores no sujeito.

Nessa perspectiva, os valores são disposições motivacionais que estão profundamente enraizadas nos domínios afetivos dos indivíduos, orientando suas interpretações sobre o mundo e, em consequência, sua própria conduta em direção a metas esperadas ou desejadas (Branco, 2012). Ainda assim, é importante observar que a posição hierárquica dos valores como signos promotores no sistema motivacional do indivíduo não é permanentemente estável, estando sujeita a mudanças em função das interações estabelecidas em determinadas situações e em contextos específicos.

Segundo Valsiner, Branco e Dantas (1997), crenças e valores se articulam de forma dinâmica e se encontram em constante transformação no decorrer das interações sociais, sendo os valores definidos como crenças com profundo enraizamento afetivo, emocional e subjetivo. A integração sistêmica, dinâmica e complexa das crenças e valores morais no universo motivacional do indivíduo, que está na base de sua ação é, portanto, de vital importância para o estudo e compreensão do desenvolvimento humano, e abrange dimensões psicológicas interdependentes como a cognição, a emoção e a ação (Barrios \& Branco, 2008).

De acordo com Abbagano (2000), no Dicionário de Filosofia, o valor em seu status metafísico tem que se diferenciar do conceito de bem. Em uma condição metafísica, o 
valor se torna independente de suas relações com o ser humano. Em outras palavras, não existem apenas os valores do bem, já que muitos dos valores que orientam a vida e as ações de diversos seres humanos não necessariamente representam algo de "melhor", seja no sentido individual ou coletivo. Segundo Rosa e González (2012), os valores desempenham um papel importante no sistema motivacional da pessoa. Nesse sentido, Rengifo-Herrera (2012) considera que valores são sistemas semióticos construídos nos níveis pessoal e coletivo, sendo frequentemente estabelecidos em consenso com redes culturais específicas. Eles são simbolicamente reconhecidos como uma linha diretiva para o grupo e isso facilita o desenvolvimento de dispositivos de ordem relacional. Por esta razão que é possível se falar em valores de paz ou de destruição (violência).

Na visão de Rosa e González (2012) os valores estão profundamente integrados na identidade cultural e pessoal porque tornam possível a escolha entre o que é importante ou dispensável à experiência da pessoa, atuando, assim, em seu processo de autoconstrução. Nessa perspectiva, os autores consideram que valores são construtos psicológicos que podem se tornar inteligíveis quando se materializam em atuações direcionadas para alcançar alguma classe particular de objetivos, quando a pessoa parece orientar sua atuação para alcançar alguma experiência especial.

Branco, Palmieri e Gomes Pinto (2012) refletem que os valores têm sua raiz na filosofia e epistemologia, estando sua base na construção cultural que, historicamente, direciona o desenvolvimento científico. Assim, o conhecimento científico sobre a sociogênese e a ontogênese da cultura e dos valores humanos é necessário para empoderar pessoas e instituições com agencialidade suficiente para exercer significativas mudanças nas práticas sociais associadas a tais valores. As autoras buscam demonstrar que o processo de canalização cultural, através do qual existe maior facilidade na construção de certas práticas e valores, pode também ser alterado por mudanças intencionais em direção a construções consideradas mais desejáveis. $E$ assim, por exemplo, valores e práticas cooperativas podem ser promovidos por forças ativas na família, escola, mídia e outros relevantes contextos de desenvolvimento, na contramão dos valores de competição e individualismo que marcam a cultura de nossa sociedade nos dias de hoje.

Staub (2003) sugere que os valores sociais se encontram dinamicamente organizados e hierarquicamente integrados no sistema motivacional da pessoa, aí incluindo outros elementos como, orientações para objetivos pessoais, necessidades, preferências e motivos, bem como formas internalizadas de normas, regras e hábitos específicos da cultura. Os valores sociais representam, para o autor, importante parte do sistema complexo da motivação social, pois os valores tendem a orientar e promover 
comportamentos e interações específicos ao longo do processo de socialização. Nessa visão, o comportamento pró-social é motivado para beneficiar outras pessoas, a cooperação beneficia a todos, e os comportamentos antissociais dificultam ou, às vezes, até impossibilitam a convivência entre os seres humanos.

Segundo Scheler (2008), os valores são coconstruídos na experiência individual e social, e as relações entre o eu e os outros são fundamentais na configuração tanto da individualidade como da coletividade. Ele reconhece uma condição universal dos valores nos indivíduos, no entanto aceita uma objetividade social que permite às coletividades suscitar e produzir valores diferenciados. Rengifo-Herrera (2014) corrobora essa ideia e propõe que "os valores são o eixo de relacionamentos com o próximo e os principais instrumentos simbólicos para os sujeitos encararem as diferentes exigências sociais e culturais, especialmente no que tange às ações a respeito de outros sujeitos" (p. 3).

Sendo assim, estudar e compreender os processos de construção de valores envolve uma análise que perpassa a sociogênese, a ontogênese e chega à microgênese. São processos desenvolvimentais que, quando considerados de forma global, tendem a revelar seus aspectos mais abrangentes e complexos, gerando maior compreensão do fenômeno, em nível individual e coletivo.

Procuramos, nesse capítulo, refletir sobre os aportes teóricos fundamentais da Psicologia Cultural em sua versão coconstrutivista, bem como refletir sobre os processos semióticos da coconstrução de valores, alimentados pelas práticas sociais vigentes na cultura. A partir dessas considerações, vamos adentrar na discussão dos conceitos mais específicos que envolvem a temática da Violência e da Paz. A seguir, tais conceitos são analisados de maneira a fundamentar o caminho adotado pela presente pesquisa rumo à construção de conhecimentos sobre as crenças e os valores implicados na formação de oficiais da Polícia Militar e a possibilidade de que esta formação venha, futuramente, contemplar a promoção de uma Cultura de Paz. 


\section{CAPÍTULO 2 \\ VIOLÊNCIA E PAZ: ASPECTOS TEÓRICO-CONCEITUAIS}

A compreensão de fenômenos como a paz e a violência envolvem muitos aspectos, tanto pessoais quanto sociais, e se transformou em uma necessidade importante nos contextos atuais. A análise sobre a origem de ações e valores de paz ou violência exige estudos minuciosos, no sentido de entender suas práticas, significados e transformações, bem como de criar estratégias para a adoção de posicionamentos e condutas diante das situações que envolvem esses fenômenos (Rengifo-Herrrera, 2014).

\section{1- A Questão Conceitual}

Antes de analisar a questão conceitual relativa à violência e à paz, é necessário relembrar aqui que, na perspectiva da psicologia cultural, os dois conceitos não constituem uma dicotomia, ou seja, não representam categorias opostas mutuamente exclusivas. Como vimos anteriormente, Valsiner (1998) destaca a importância de consideramos, na psicologia, categorias aparentemente antagônicas ou excludentes como mantendo, de fato, uma relação de separação inclusiva, isto é, existe sempre uma relação de interdependência entre elas, uma vez que fazem parte de um mesmo fenômeno.

\section{Violência}

A violência é um tema que há muito tempo vem sendo pensado e debatido, tanto no ambiente acadêmico quanto no âmbito social, pois atinge diretamente todas as esferas que compõem a sociedade. Ela está frequentemente associada à agressão, e ultrapassa o limite estabelecido pela necessidade de respeito e consideração pelos outros, seja em nível pessoal ou institucional. Agressão e violência impedem e dificultam o desenvolvimento individual e social que, ao se tornarem uma prática cultural corriqueira, acabam por gerar significados no contexto sociocultural que certamente dificultam a promoção da paz e a melhoria na qualidade de vida das pessoas (Moreira, 2011).

Segundo o Dicionário Aurélio de Língua Portuguesa (2015), o significado de violência relaciona-se à qualidade ou caráter de ser violento. Ato ou efeito de violentar. Abuso da força. Opressão, tirania. Constrangimento físico ou moral exercido sobre alguém; coação. De acordo com o Dicionário Informal (2015) violência é o exercício desproporcional do poder ou força que se sobrepõe ao princípio da integridade (física, emocional, moral, religiosa, étnica, laboral, familiar, doméstica, empresarial, etc). Como podemos observar, os significados propostos pelos dicionários citados trazem definições 
que reafirmam nosso conceito de violência como coação, excesso do uso da força ou o abuso de poder associado ao desrespeito à integridade individual.

Em grande parte das vezes, a expressão da violência relaciona-se com a existência de um conflito não resolvido adequadamente. Ao agir de maneira violenta, o conflito torna-se declarado e é definido por aquele que detém maior poder, gerando a opressão. Consiste no exercício abusivo do poder, ou na própria disputa pelo poder, o que traz dificuldades para a possibilidade de negociações construtivas e concretas para a resolução pacífica dos problemas.

Segundo o Ministério da Saúde (2009), a violência é um problema social de grande dimensão que afeta toda a sociedade, atingindo todos os seus membros durante diferentes períodos de suas vidas. É responsável no mundo inteiro por adoecimento, perdas e mortes e se manifesta através de ações realizadas por indivíduos, grupos, classes e nações, provocando danos físicos, emocionais e/ou espirituais à própria pessoa ou aos outros com quem interage.

Galtung (2006) distingue dois tipos de violência: física e psicológica. A primeira pode ser direta, quando o uso da força provoca danos corporais, ou indireta, quando há exploração de qualquer ordem. A segunda, a violência simbólica, também pode ser direta (verbal ou não verbal) e indireta, quando há a destruição de bens pessoais ou coletivos, culturais ou simbólicos, valorizados quer por pessoas, quer por grupos específicos.

Em seus estudos sobre violência, Minayo (1999) argumenta que é a violência um fenômeno biopsicossocial complexo e dinâmico, e que seu espaço de criação e desenvolvimento é a própria vida em sociedade. Na medida em que a violência é definida como "uma relação humana", Minayo (1994) afirma que é possível compreendê-la como um comportamento culturalmente aprendido, que passa a fazer parte dos padrões intrapsíquicos. Portanto, é um fenômeno que pode ser desconstruído. Entretanto, quando o fenômeno é analisado em suas expressões concretas, e assumido como objeto de reflexão, é possível que ocorra uma superação da violência em busca de formas mais construtivas de resolução de conflitos.

Garapon (1999) afirma que "a violência é um processo infinito que clama continuamente por outra violência superior" (p. 256). Essa afirmação é muito pertinente no campo da análise do comportamento, onde os comportamentos reforçados positivamente tendem a se manter e transformar em hábitos. O autor ainda reflete que pretender dominar a violência com violência é criar e alimentar uma escalada de vingança, na qual se torna improvável diferenciar o criminoso da autoridade, e a escalada da violência pode levar qualquer sociedade à aniquilação (Garapon, 1999). Nesse sentido, torna-se relevante recriar novos conhecimentos sobre a questão da violência para que as ações que buscam sua repressão não terminem por maximizar seus efeitos 
nas pessoas e nas sociedades. Este argumento apresentado pelo autor sugere, assim, claramente, que a prevenção da violência é muito mais eficiente do que a sua repressão.

A violência, no entanto, não deve ser considerada como sinônimo de agressividade, força ou luta (Muller, 2007). De acordo com este autor, a agressividade e a força exercidas na luta podem ser uma forma de mediação do conflito. Para ele, a violência é uma desorganização do conflito e inibe o funcionamento do conflito e não the permite desempenhar sua função de estabelecer um acordo entre as partes. "Não há paz sem justiça e não há justiça sem luta, mas as lutas devem acontecer a partir de meios não violentos" (Muller, 2007, p. 181). Este é o caso, por exemplo, da luta pelos Direitos Humanos e pela democracia.

\section{Paz}

Para o psicólogo norte-americano David Adams (2005), responsável pelo relatório da ONU sobre a Década da Cultura da Paz, a maioria dos países do mundo ainda tem uma cultura de guerra, pois ela imperou, no mínimo, por mais de 5.000 anos. Ele concorda com Mead (1970), que considera a guerra como uma instituição inventada, e argumenta que "os mesmos que inventaram a guerra têm de inventar a paz, porque a paz também é uma instituição" (Adams, 2005).

Adotando a perspectiva de que a paz pode ser ativamente construída, autores como De Rivera (2004, 2009), Jares (2002), Milani (2003), Dusi (2006), Senna (2007), Valsiner (2009), Moreira (2011), Branco (2012) e Rengijo-Herrera (2014) compreendem que a paz é um fenômeno amplo e complexo que exige uma compreensão multidimensional, e que deve ser analisado no sentido de produzir conhecimentos que venham a ser úteis na promoção daquilo que conceituam como Cultura de Paz.

O conceito de paz adquire diferentes significados nos diferentes contextos histórico-culturais, seja em nível macro das sociedades, seja em nível meso e micro dos contextos de socialização específicos das interações humanas. Nas palavras de RogerPol Droit (2006), "a paz provém da maneira como são estabelecidas as relações: entre indivíduos, entre grupos sociais, entre Estados, entre culturas" (p. 214). Segundo Moreira e Branco (2012), somente através da adoção de uma visão ampla será possível melhor compreender a paz enquanto processo complexo de coconstrução.

Segundo o Ministério da Saúde (2009), a paz é um fenômeno complexo que envolve a construção de uma estrutura social e de relações sociais em que exista justiça, igualdade, respeito, liberdade, e que seja caracterizada pela ausência de todo o tipo de violência. A paz está relacionada ao desenvolvimento humano de toda a sociedade, aos Direitos Humanos, à aceitação da diversidade e à efetiva cooperação entre pessoas, grupos ou nações. 
A noção de paz tornou-se bastante complexa para ser definida atualmente, devido às suas características e significados presentes nos diálogos da vida contemporânea. $\mathrm{A}$ paz tornou-se um conceito com múltiplas possibilidades de compreensão e, segundo Rengifo-Herrera (2014), o equilíbrio e a estabilidade são muitas vezes considerados como condições primárias para a existência da paz. O autor postula que a harmonia e a tranquilidade são algumas das características presentes num contexto de paz, e critica o que vê como uma forte tendência a se considerar a paz como uma condição permanente e imutável, o que não é factível.

Paz não significa ausência de conflitos, mas deve ser compreendida como um processo positivo, dinâmico e participativo em que se promove o diálogo e a resolução dos conflitos em um espírito de cooperação (Dusi, 2006). Dessa forma, a paz envolve uma visão de construção permanente, ação e investimento pessoal e coletivo, que pode modificar as pessoas e o mundo à sua volta através das interações concretas entre as pessoas.

Jares (2002) reafirma que a paz se refere a uma estrutura e a relações sociais caracterizadas não só pela ausência de todo tipo de violência, mas pela presença da justiça, da igualdade, do respeito e da liberdade, valores humanistas reconhecidos na Declaração dos Direitos Humanos das Nações Unidas.

Valsiner (2009), por sua vez, argumenta que o eterno movimento entre guerra e paz é organizado pelos reguladores semióticos atuantes na cultura. Esta característica dinâmica dos processos sociais tem implicações para qualquer descrição de um estado de Cultura de Paz, e a dinâmica envolvida nos processos de coconstrução da paz implica em considerar a unidade dos opostos, violência e paz. Nenhum indicador estático específico poderá gerar, manter e, muito menos, medir a paz. Como reiterado em inúmeras contribuições acadêmicas (De Rivera, 2009), acredita-se que uma sociedade cujo sistema educacional leva homens e mulheres a usar meios pacíficos para cessar conflitos é potencialmente geradora de processos de coconstrução da paz (Branco, 2012; Valsiner, 2009).

A Unesco (1995), através da Declaração Mundial dos Princípios sobre a Tolerância, ressalta que um dos caminhos para a paz é a tolerância e que ela deve transformar as diferenças em harmonia, em qualquer contexto. "A tolerância é, antes de tudo, uma atitude ativa fundada no reconhecimento dos direitos universais da pessoa humana e das liberdades fundamentais do outro" (p. 11). Por isso a tolerância deve ser compreendida como "um princípio e uma virtude que torna a paz possível e contribui para substituir uma cultura de guerra por uma cultura de paz" (p. 11). Assim, a tolerância trabalha no sentido de que os seres humanos têm o direito de viver e conviver em paz. 
No entanto, vale ressaltar que tolerância não é sinônimo de conformidade ou passividade. Em nossa perspectiva, a tolerância é a base para a resolução pacífica de conflitos, assim como a base para o desenvolvimento pessoal e social rumo a transformações construtivas e necessárias. Assim, a ideia de transformar "diferenças em harmonia", presente no texto da Unesco (1995) acima referido, merece discussão: na vida, a noção de um estado de harmonia onde não existam conflitos não faz sentido. $A$ vida em sociedade necessariamente, e para o seu próprio desenvolvimento, envolve conflitos, os mais diversos. O conceito de 'harmonia' deve, portanto, não se referir a uma realidade impossível de existir, mas sim, incluir a existência, utilização e criação de estratégias pacíficas para a mediação dos conflitos inerentes à vida.

\section{2- Conflitos: Conceito, Função Desenvolvimental e Mediação}

Conflitos declarados e não declarados geradores de violência têm ocorrido com grande frequência ao longo da história. Isto se verifica em diferentes níveis, desde o nível micro - como nas famílias, escolas etc - como em nível macro, no contexto urbano, regional, nacional ou internacional.

A paz envolve a ausência de guerra, porém, a categoria de ausência de algo deve ser visto a partir de uma perspectiva relativa e histórico-cultural (Valsiner, 2009). O autor pondera que a natureza multivalorizada das transições entre os opostos é o mais relevante, pois os opostos não são dois estados distintos de maneira dicotômica sobre os quais os significados humanos divergem, mas sim campos nebulosos de significação onde o significado dominante, em determinado momento e contexto, cresce e se sobressai. Um estado de paz pode ser transformado em guerra de forma abrupta, ou através de um longo período de incerteza, onde a violência pode ser um fenômeno diário. Da mesma forma, o movimento dominante para minimizar a guerra e chegar à paz pode ser gradual e pleno de avanços e retrocessos. Construir a paz em zonas de guerra por meio de ataques e negociações intergrupos pode levar décadas, envolvendo a continuidade das gerações e ainda assim falhar. Preconceitos podem ser mantidos ao longo de muitas gerações, dando origem a diferentes atos agressivos provenientes de todos os lados e situações (Valsiner, 2009).

De acordo com Jares (2002) "o conflito é um tipo de situação na qual as pessoas ou os grupos sociais buscam ou percebem metas opostas, afirmam valores antagônicos ou têm interesses divergentes, ou seja, é um fenômeno de incompatibilidade" (p. 135). Este autor ressalta que a paz nega a violência, porém não os conflitos, pois estes fazem parte da vida. Considera que o conflito não é um acontecimento de um único momento, mas um "fenômeno evolutivo" (pág. 136). Assim, no processo de construção da paz há 
presença de conflitos, mas a grande diferença está em que contextos específicos eles surgem, e como eles são negociados e resolvidos (Moreira, 2011).

Os conflitos são essenciais para o aprimoramento das relações entre os seres humanos, e para a construção de uma sociedade mais justa, igualitária, democrática e plural (Melman, Ciliberti, Aoki \& Figueira Junior, 2009). Atuam, portanto, como uma força motivadora que promove mudanças individuais e sociais, a partir da qual é possível trilhar o caminho em direção à paz.

Conflitos entre pessoas, grupos e organizações são inevitáveis. A diversidade é geradora de conflitos, e não devemos necessariamente evitá-los. Percebe-se, porém, muita resistência das pessoas em admitir o conflito como algo positivo (Manzini, 2013). Isto ocorre pelo fato de não saberem diferenciar divergências e posicionamentos distintos de violência e agressividade, sendo estes últimos geradores de ações responsáveis por eliminar as diferenças pela imposição não democrática daqueles que detém maior poder sobre aqueles menos poderosos (Moreira \& Branco, 2012).

A partir dessas análises e discussões, compreendemos que o conflito possui, sim, uma função desenvolvimental, ou seja, ele promove desenvolvimento. Valsiner e Cairns (1992) resumem a questão e propõem que onde existe relação, ou relacionamentos, necessariamente haverá conflito, e estes são de grande importância na própria promoção do desenvolvimento humano, particularmente aqueles conflitos que os autores consideram como tipicamente construtivos. Segundo os autores, toda e qualquer situação, que possa ser discutida e refletida de forma inteligente e madura, retira a pessoa de uma zona de conforto, estática, e a leva para a necessidade de transformação, chegando à novidade. Cada situação divergente ou antagônica, origem de todo conflito, se revisada e bem mediada, poderá, em princípio, elevar as pessoas ou grupos envolvidos a uma condição melhor que aquela vivenciada no início do conflito.

\section{Mediação de Conflitos}

Como anteriormente ponderado, os conflitos constituem uma divergência de posicionamentos que se revelam nas relações e nos processos comunicativos, os quais geram um sentimento de dificuldade (às vezes, quase impossibilidade) de se alcançar uma convergência, seja esta de interesses ou de posicionamentos teóricos e/ou práticos. Na medida em que são retroalimentados e não mediados, tendem a ampliar seu raio de abrangência, tendo grande possibilidade de se transformar em violência.

Seidel (2007) pondera que, frente ao conflito, se pode assumir três atitudes básicas: ignorá-los; responder de forma violenta; ou, então, lidar com os conflitos de forma não violenta, por meio da negociação e do diálogo. O autor, ainda, considera que é 
justamente a não aceitação do conflito que acaba provocando a violência, ou seja, quando não há esforço para mediá-lo ou resolvê-lo abre-se espaço para a violência.

Estratégias de mediação de conflitos são diferentes de uma simples "resolução" de conflitos. A mediação de conflitos traz os conflitos sob controle, enquanto as estratégias de resolução de conflitos podem apenas consistir, às vezes, em tentativas para encerrar o conflito. A mediação de conflitos reconhece a importância do conflito construtivo nas relações e pode ser uma estratégia de prevenção de conflitos violentos. Pesquisas empíricas sobre conflitos, no entanto, têm focado mais a situação genérica do que as características do contexto cultural (Staub, 1991), o que precisa ser revisto com urgência.

Nesse sentido, as novas propostas para mediação de conflitos são práticas emergentes capazes de atravessar a diversidade dos contextos sociais e elas transitam entre o existente e o possível. Estas propostas são estruturadas para capacitar as pessoas a desenvolverem habilidades e competências que lhes permitam compreender tanto as diferenças, como as convergências. São processos auto-organizativos que operam em sistemas complexos, nos quais os participantes, ao coconstruírem novas possibilidades de resolver seus conflitos, reconstroem suas relações e, também, a si mesmos (Schnitman \& Littlejohn, 1999), modificando com isto todo o seu contexto sociocultural.

Estudos sobre mediação de conflitos têm sido desenvolvidos especialmente nos últimos 15 anos, acompanhando os novos paradigmas da ciência e as mudanças sociais. O trabalho de Schnitman e Littlejohn (1999) propõe construir novas formas de ação que propiciem sentido de comunidade, e que modifiquem a vida social e a qualidade de vida das pessoas. As metodologias para a resolução de conflitos tornam-se instrumentos para repensar a própria cultura, a transformação dos discursos e das práticas institucionais e culturais. Sua proposta orientadora considera que o conflito é também uma oportunidade de crescimento e desenvolvimento, superando lógicas binárias do modelo ganhar-perder, se interessando pelas possibilidades criativas que contemplam as diferenças, a diversidade e a complexidade como elementos positivos (Schnitman \& Littlejohn, 1999).

Os enfoques propostos por Seidel (2007) apoiam modelos comunicativos e discursivos nos quais é possível entender a evolução de um conflito observando não só as emoções e as crenças, mas também outros domínios simbólicos, como as construções narrativas, e as dialogias que constroem e transformam significados e práticas, projetos e resultados. Entender os sujeitos como coconstrutores de suas realidades promove diálogos significativos para a resolução de conflitos e pressupõe a polifonia de vozes (Bakthin, 2003), e a diversidade de experiências e culturas. Isto, por 
sua vez, viabiliza as interações sociais e a comunicação como uma dimensão transversal da mediação de conflitos.

Dessa forma, as pessoas envolvidas no conflito devem ter a capacidade de se questionar sobre as diversas estratégias disponíveis de enfrentamento, bem como refletir e formular questões significativas, ampliando os meios ativos de enfrentar os conflitos e resistir às simplificações propostas por velhos paradigmas.

Staub (2003) considera que os fatores culturais são fundamentais e determinam o sucesso ou o fracasso da mediação de conflito, tanto em nível macro como micro. Postula que a mediação pode suceder ou conduzir a diferentes razões, dependendo do contexto cultural. Ele afirma que precisamos entender melhor como fatores significativos do contexto cultural influenciam o processo de mediação de conflito, o que pode nos auxiliar a explicar falhas e a prever o sucesso da mediação.

Conflitos construtivos entre indivíduos ou grupos possibilitam uma perspectiva de consenso, prevenindo que certos indivíduos ou grupos possam polarizar um contra o outro, criando dicotomias e antipatias perigosas. A cultura define valores e interesses que são da essência do conflito, formando percepções, criando alternativas e definindo resultados como positivos ou negativos (Staub, 2003). A comunicação sobre conflitos na mediação cultural e as estratégias da mediação construtiva de conflitos dependem dos recursos das culturas pessoal e coletiva para que seja possível a definição e a negociação de interesses comuns.

Nesse sentido, devemos considerar que os conflitos construtivos criam e conduzem ações fundamentadas na solidariedade e nos valores pró-sociais, podendo gerar práticas de cooperação. Seguindo nessa discussão, vamos refletir sobre como esses valores e virtudes influenciam no desenvolvimento moral, podendo ser promotores da Cultura de Paz.

\section{3 - A Dimensão Sócio-Moral do Desenvolvimento Humano e a Cultura de Paz: o papel dos valores e virtudes}

A partir das questões conceituais discutidas anteriormente envolvendo paz, violência, conflitos e valores, pretendemos agora ampliar nosso olhar sobre a dimensão sócio-moral do desenvolvimento humano como um meio que proporciona a construção de valores e virtudes, e a possibilidade de canalizá-los para a promoção de uma Cultura de Paz. Entendemos que essa dimensão é uma vertente do ser humano construída e desenvolvida a partir da interação com seu contexto sociocultural, e resultada de uma trajetória de vida que envolve suas experiências.

O estudo da dimensão sócio-moral do desenvolvimento humano tem avançado nas últimas décadas e já começam a surgir discussões com base em novas perspectivas 
sobre o tema, no âmbito acadêmico. Martins e Branco (2001), ao criticar o predomínio da abordagem cognitivo-construtivista, propõem que o estudo do desenvolvimento moral deve contemplar o caráter histórico-cultural, dialógico e processual da realidade social e psicológica da moralidade. Ou seja, os conceitos morais e éticos que atuam na vida cotidiana das pessoas passam, necessariamente, pelo crivo sociocultural.

Lourenço (1998), analisando a literatura, observa que o desenvolvimento moral vem sendo estudado na psicologia a partir de algumas perspectivas teóricas. A abordagem psicanalítica argumenta que a pessoa moralmente mais desenvolvida é a que mais interiorizou e se identificou com os valores e padrões parentais, é a que mais resiste ao princípio do prazer, e a que mais sente culpa após determinadas transgressões (Freud, 1968). A abordagem comportamental (Skinner, 1971) sustenta que a moralidade é fundamentalmente o resultado de contingências, e as respostas morais são resultado de esquemas de reforçamento. Os psicólogos da aprendizagem social, dentre eles Berkowitz (1964), defendem que o desenvolvimento moral é ser capaz de seguir normas e regras consideradas corretas pelos membros de uma sociedade. O próprio Lourenço (1999), entretanto, adota uma abordagem estrutural construtivista, afirmando que a moral é construída a partir de ideias e princípios éticos universais, e a ação moral é regulada por tais princípios, estudados por Piaget (1932/1994) e Kohlberg (1984). Nessa visão, as razões e intencionalidades de uma conduta são essenciais para identificá-la como uma ação como moral.

La Taille (2000) também se apoia no construtivismo e considera que as pesquisas em psicologia moral definem como morais aquelas condutas que "respeitam o direito alheio e o juízo que o considere" (p. 120). Segundo sua visão, Piaget (1932/1994) considera a moral como um conjunto de princípios e regras relacionados a histórias específicas. Kohlberg (1984) coloca a justiça como eixo de toda moral, e Turiel (1993) define o domínio moral como referente à justiça, definido por regras que são julgadas como universais, pois correspondem aos direitos de toda e qualquer pessoa. Na reflexão de La Taille (2000), Gilligan (1982) seria a única "voz destoante na Psicologia", pois considera, para além da justiça, a ética do cuidado, que conduz à virtude da generosidade. No entanto, como veremos adiante, a psicologia cultural vê a questão sob um ângulo sistêmico e bem mais abrangente (Branco, 2012; Ratner, 2002)

Gilligan (1982) define a ética do cuidado a partir de uma concepção de moralidade que considera o desenvolvimento moral em torno da compreensão da responsabilidade e dos relacionamentos. A autora pondera que as consequências que envolvem moralmente as pessoas em um relacionamento devem ser consideradas, levando-se em conta a ética do cuidado e da generosidade. 
Devemos compreender que na "ética do cuidado" está o exercício de muitas virtudes como amor, tolerância, compaixão, fidelidade, temperança e generosidade. Gilligan (1982) considera que "a consciência de múltiplas verdades leva a uma relativização da igualdade no sentido da equidade e enseja uma ética da generosidade e do cuidado" (p. 178). Cuidar do outro quase sempre nos convoca a dar mais do que the é de direito, portanto, também cabe aqui a virtude do altruísmo.

$\mathrm{Na}$ perspectiva da Psicologia Cultural, entretanto, entende-se que o desenvolvimento moral ocorre em um processo histórico de constituição mútua entre indivíduo e sociedade, de forma concomitante. Os valores morais vão sendo construídos pela pessoa em interação com seu contexto sociocultural que, em seus níveis micro e macro, também vai sendo transformado pela interação com as pessoas que nele se inserem e com outras culturas (Branco, 2012; Moreira \& Branco, 2012).

Shweder e Much (1991) enfatizam o papel da cultura e argumentam que as crenças morais têm sua origem ontogenética nas mensagens e significados implicitamente transmitidos a partir da fala, da conversação, do discurso e da prática cotidiana. Sugerem que os julgamentos morais que são comuns a culturas diferentes são aprendidos por razões que fazem sentido para vários grupos, ao passo que os julgamentos morais que são distintos de cada cultura, existem porque fazem sentido apenas para determinados contextos. A partir dessa ideia, os autores propõem que os conceitos morais devem ser pautados em uma análise semiótica abrangente e ampliada, que contemple a vida social do indivíduo.

A forma como os valores morais, ou a ausência deles, direcionam nossas ações e decisões de maneira poderosa não podem ser desconsideradas (Branco, 2012). A ação moral está, pois, relacionada com a motivação pessoal para o exercício da moralidade, e é contextualizada e transversalizada por uma cultura, onde os princípios, ideais e julgamentos são formados. Com base no contínuo processo de coconstrução do desenvolvimento moral, os conceitos saem do nível do discurso para a ação, transformando as pessoas em cidadãos comprometidos-ou não-consigo mesmos e com a coletividade (Moreira \& Branco, 2012).

Rengifo-Herrera (2014) reconhece uma condição, ou função universal dos valores na vida das pessoas e propõe que "os valores são o eixo de relacionamentos com o próximo e os principais instrumentos simbólicos para os sujeitos encararem as diferentes exigências sociais e culturais, especialmente no que tange às ações a respeito de outros sujeitos" (p. 3).

Sendo assim, estudar e compreender os processos de construção de valores, que envolve, também em seu bojo a questão da virtude, envolve uma análise abrangente de importantes aspectos de sua sociogênese, a ontogênese e, também, microgênese. Aí 
estão implicados processos desenvolvimentais que, quando considerados de forma global, tendem a revelar seus aspectos mais abrangentes e complexos, gerando maior compreensão do fenômeno, em nível individual e coletivo.

\section{Valores e Virtudes}

O mundo contemporâneo tem retomado discussões e reflexões sobre a ética, os valores e as virtudes na sociedade, o que já faz parte da experiência humana desde seus primórdios. Isso demonstra uma crescente preocupação com as pessoas, suas ações e comportamentos no mundo atual, onde o que se percebe é justamente o contrário: a falta de ética e de virtudes.

Segundo Madureira e Branco (2012), os valores desempenham um papel fundamental no sistema motivacional da pessoa, e agem também no sentido de promover continuidade do self dialógico (Markova, 2006) ao longo de seu desenvolvimento. Essa visão é compartilhada por Rengifo-Herrera (2012), que considera os valores como importantes instrumentos simbólicos para os sujeitos encararem as diferentes exigências sociais e culturais, especialmente no que tange ao respeito.

Os valores, como vimos anteriormente, estão diretamente relacionados com conteúdos afetivos (Valsiner, Branco \& Dantas, 1997) que resultam dos afetos estabelecidos nas relações e nos processos semióticos coconstruídos ao longo da trajetória de vida de cada pessoa. Valsiner (2014) argumenta, assim, que os valores são recursos humanos básicos de orientação afetiva ontogeneticamente internalizados; porém, sua externalização pode ser observada em diversos aspectos da conduta humana.

Rengifo-Herrera (2014) propõe que os conceitos desenvolvidos a partir da perspectiva semiótico-cultural permitem realçar o papel dos valores como categorias anteriores que conduzem a ações em uma realidade futura. Nesse sentido, o estudo dos valores possibilita acessar o sistema motivacional das pessoas compreender suas estratégias de enfrentamento frente às mudanças em suas trajetórias de vida.

As pesquisas indicam que ligações afetivas como a amizade, o parentesco, a exposição da intimidade e o sentimento de vergonha sejam fatores de grande importância na determinação da moralidade, inclusive na diferenciação entre o juízo moral expresso e a ação correspondente realizada em determinadas condições (Lima, 2004).

Sabemos que a motivação pró-social tende a gerar comportamentos pró-sociais, e, ao contrário, a hostilidade como motivação social recorrente acaba por promover a agressão. Eisenberg, Fabes e Spinrad (2006) apontam as diferentes modalidades do comportamento pró-social, o qual inclui ações altruístas, mas também ações motivadas por interesses específicos por parte daquele que beneficia o outro social. Os autores 
destacam que no altruísmo existe a presença de um elemento motivacional interno, isto é, o indivíduo é motivado a atuar de forma voluntária visando ao benefício de outras pessoas, sem a perspectiva aparente de ganhos pessoais, à exceção da autorecompensa.

Conceitos como cooperação e ajuda, assim, consolidam a ideia de que ações e interações voltadas para a paz podem ser desenvolvidas e dependem tanto dos sujeitos quanto das sociedades envolvidas no processo. Motivação e ações pró-sociais estão profundamente relacionadas à ética (normas coletivas) e à moralidade (princípios pessoais) (Freitag, 1997), e podem surgir com base em reflexões conscientes aplicadas à transformação individual, orientadas para a construção e vivência de práticas pró-sociais fundamentais para a construção de uma Cultura de Paz. Princípios como justiça e solidariedade teriam, assim, um caráter de necessária universalidade na promoção da paz.

A partir das visões teóricas aqui discutidas, podemos analisar que tanto indivíduos quanto grupos e instituições possuem valores específicos, e mediações semióticas atuam no sentido de incentivá-los e mantê-los através de práticas cotidianas. Os valores finais são aqueles que fornecem sentido e tornam a experiência, ou a própria vida, significativa. Cada cultura fornece valores finais sobre o que torna uma vida digna de ser vivida (Bergman, 2004). É por isso que esses valores são tão profundamente enraizados na identidade pessoal e cultural, porque eles tornam possível uma escolha entre o que é importante ou dispensável à experiência da própria vida da pessoa (Bergman, 2004).

O livro editado por Galán (2005), intitulado "Democracia y virtudes cívicas", apresenta, discute e ressalta a importância das virtudes individuais no desempenho das atividades coletivas. A virtude, para os autores deste livro, é definida como uma espécie de excelência. É uma realidade que a ideia de conseguir excelência na atividade humana tem sido explorada em vários setores da vida, sendo mais enfatizada e exigida no mundo profissional. Camps (2005), por exemplo, enfatiza que a sociedade atual democrática e liberal necessita de pessoas virtuosas tanto quanto necessitava a sociedade grega. Entretanto, a psicologia pouco tem se dedicado a esta questão.

Pensar em uma comunidade específica com traços culturais favorecedores de virtudes pode ajudar a construir uma identidade moral que permitiria as pessoas viverem juntas sem se destruir mutuamente. "O indivíduo que se propõe a ser verdadeiramente humano, que transforma a comunidade em que vive, sua profissão ou funções que exerce na comunidade, merece ser chamado de ético" (Camps, 2005, p. 23). A autora pondera, ainda, que a virtude da prudência está sendo cada vez mais necessária em nossa sociedade. Constata-se que sua demanda é crescente, sobretudo no mundo profissional, onde a falsidade e a competição têm se tornado fonte de preocupação. 
Galán (2005), por sua vez, reafirma a necessidade de virtudes públicas, enfatizando que a luta pela tolerância tem sido paralela à conquista da liberdade no mundo moderno. Ou seja, à medida que o ser humano conquista a liberdade para agir, também deveria adquirir tolerância para com os outros e responsabilidade por suas ações, promovendo a paz. O autor cita a famosa frase de Voltaire "a tolerância é patrimônio da humanidade" (p. 191) e compartilha a ideia, afirmando que essa é uma virtude primordial para o ser humano como ser necessariamente social.

A ideia de virtude pública também engloba os valores e crenças transformados em ação. Os valores, assim com as virtudes, ajudam o ser humano a ser livre, e cada atitude individual acaba por refletir na vida coletiva, buscando melhorá-la. Camps (2005) reforça essa ideia dizendo que "a moral e as virtudes são uma tarefa individual, mas sua função é pública" (p. 31).

Tognetta e La Taile (2008) ponderam que é compreensível a razão pela qual as virtudes sejam de suma importância para os homens: "o fato de elas possibilitarem a todo homem uma leitura valorativa de si próprio e dos outros, elas fazem parte do quadro de referências a partir do qual cada um se entende como ser humano" (p. 185). Não somente as virtudes incidem sobre qualidades de cada pessoa, como elas apontam para qualidades apreciadas, admiradas. Assim sendo, as virtudes não se referem apenas a uma leitura valorativa da pessoa humana, mas às qualidades desejadas.

Virtudes e caráter são construídos, primeiro, através da prática e da educação e, depois, por meio de processos ativos de construção do self. Este não é, porém, apenas um processo autopoiético que configura a vida, que se movimenta criando um novo domínio de direção moral e ideais éticos, de direitos e dignidade. Este é, sobretudo, um processo de construção do conhecimento, do desenvolvimento de instituições sociais e da criação de novos direitos e deveres, sob a égide de valores culturais promotores da dignidade humana (Rosa \& Gonzalez, 2012). Em resumo, relaciona-se com a mútua transformação da realidade e da humanidade ao longo da história.

Dessa forma, os valores culturais e as virtudes vinculam-se intimamente às motivações e crenças internalizadas com forte carga afetiva e estão na base e na forma como as pessoas enfrentam e lidam com as constantes transformações em seus contextos, e constituem, portanto, fortes pilares da construção de uma Cultura de Paz.

\section{Cultura de Paz}

A Cultura de Paz está diretamente relacionada com a necessidade emergente do mundo contemporâneo por mudanças, no sentido de cultivar valores e virtudes que melhorem a qualidade de vida das pessoas. De Rivera (2009) pondera que estudos 
recentes têm começado a examinar a relação entre valores e as bases para uma Cultura de Paz.

O termo Cultura de Paz foi proposto pela Organização das Nações Unidas - ONU (2000) ao lançar o documento "Manifesto 2000". Este definiu Cultura da Paz como um conjunto de valores, atitudes, tradições, comportamentos e estilos de vida de pessoas, grupos e nações baseados no respeito pleno à vida e na promoção dos direitos humanos e das liberdades fundamentais, na prática da não violência por meio da educação, do diálogo e da cooperação, podendo ser uma estratégia política para a transformação da realidade social. Ao assinar o manifesto, as pessoas comprometem-se a passar adiante os valores da paz, da tolerância e da solidariedade e converter em realidade e cotidiano os valores, as atitudes e os comportamentos que inspiram a Cultura de Paz.

Besabe e Valencia (2007) refletem que o conceito de Cultura de Paz foi desenvolvido a partir de oito diferentes aspectos. São eles: (1) Educação para a resolução pacífica de conflitos; (2) Desenvolvimento Sustentável (que envolve a erradicação da pobreza, a redução das desigualdades e sustentabilidade ambiental); (3) Direitos Humanos; (4) A igualdade de gênero; (5) A participação democrática; (6) A compreensão, a tolerância e a solidariedade (entre os povos, grupos vulneráveis, e migrantes dentro da nação, e entre as nações); (7) Comunicação Participativa e as informações livres; e (8) A paz e a segurança internacional (incluindo o desarmamento).

A Cultura de Paz constitui-se, assim, em um processo dinâmico que ocorre de forma individual e coletiva, buscando transformar as mais diversas sociedades. Como vimos no capítulo 1 deste projeto, a Psicologia Cultural do desenvolvimento humano estabelece que o contexto sociocultural em que a pessoa está inserida atua de forma fundamental na construção dos mais diversos conceitos, valores e padrões de interação (Branco, 2006; Rogoff, 2005; Valsiner, 2007). Dessa maneira, a depender da prevalência de práticas violentas, ou de cooperação, entre as pessoas, contextos culturais podem gerar sujeitos mais agressivos ou mais pacíficos. Em outras palavras, um contexto cultural que valorize a paz de forma concreta tende a gerar pessoas comprometidas com a paz, e vice-versa (Milani \& Branco, 2004). Isto porque o conceito de 'paz' não pode ser visto apenas do ponto de vista teórico, ou ideal, mas deve ser analisado em termos das práticas culturais concretas para a resolução de problemas, que levam a ações específicas. A questão central é: deverá a resolução de um conflito ocorrer pela violência ou pela negociação? Por que não prevenir a violência, encontrando soluções negociadas e construtivas para as divergências interpessoais, ou intergrupais? Pode-se afirmar que as ações que buscam construir e manter a paz nos mais diversos contextos são, sim, passíveis de serem desenvolvidas, saindo do plano das intenções para o plano das ações concretas. 
Segundo Milani (2003), um cidadão "da paz" transcende a visão de um indivíduo não violento, e implica em um sujeito ativo na sua construção. A paz é construída nas ações e interações cotidianas, envolvendo os mais diversos tipos de relações, caracterizando um movimento que é ampliado no sentido de promover uma "Cultura de Paz". Na visão de Milani, construir uma Cultura de Paz é promover as transformações necessárias e indispensáveis para que a paz seja o princípio governante de todas as relações humanas e sociais. Para tanto, define dois níveis básicos de ações: micro e macro. O primeiro refere-se ao indivíduo, seu comportamento, suas relações, sua vida cotidiana, trabalho, família, e todas as ações que podem ser construídas nas práticas sociais cotidianas de cada um. O segundo, nível macro, refere-se ao coletivo, aos processos sociais, às mudanças estruturais, institucionais, às políticas públicas e programas educativos, buscando integrá-los à dinâmica social. Os dois níveis são interdependentes e precisam ser desenvolvidos concomitantemente para a coconstrução de processos de paz.

A UNESCO tem agido sempre de acordo com os princípios delineados no preâmbulo de seu Ato Constitutivo (1991) e reafirma a ideia de que "uma vez que as guerras começam na mente dos homens, é na mente dos homens que as defesas da paz devem ser construídas" (p. 6). Nesse sentido, a Cultura de Paz pode ser, também, pensada como uma filosofia de vida. Essa ideia é compartilhada por Callado (2004), que a caracteriza como a busca individual e coletiva de um modo de vida que contribua para a construção de um mundo marcado pela justiça, solidariedade e paz. Esta busca procura resolver os problemas por meio do diálogo, da negociação e da mediação, de forma a minimizar a violência e favorecer a cooperação e o entendimento (Senna, 2007).

A passagem da Cultura da Violência para uma Cultura de Paz exige desconstruir a legitimidade do uso da violência como instrumento de resolução de conflitos (RengifoHerrera, 2014). Melman e colaboradores (2009) concordam que é preciso reconhecer a violência como algo que fere a dignidade humana, tanto da vítima quanto do agressor. Ou seja, todos acabam sendo prejudicados de alguma forma. Da mesma maneira que a presença da violência na vida cotidiana é algo real, também é possível compreender que existem outras escolhas e outros caminhos, e que os impasses podem ser superados por meio do diálogo e da negociação (Bohm, 2005).

Em resumo, a Cultura de Paz está intrinsecamente relacionada à prevenção da violência e à resolução não violenta dos conflitos. É uma cultura baseada em tolerância, solidariedade e compartilhamento em base cotidiana, uma cultura que respeita os direitos individuais, o princípio do pluralismo, que assegura e sustenta a liberdade de opinião. Ela se empenha em prevenir conflitos destrutivos, resolvendo-os em suas fontes ou origens, e a promover a mediação pacífica dos conflitos cotidianos, em nível micro e em nível 
macro. A construção da Cultura de Paz não é apenas viável, mas é possível e necessária para fomentar pessoas melhores e, consequentemente, sociedades melhores (Jares, 2002; Moreira \& Branco, 2012). Esta é uma perspectiva otimista que reconhece o desenvolvimento humano como processo contínuo e dinâmico, que envolve a ressignificação de conceitos, valores e experiências, favorecendo, assim, as efetivas transformações individuais e coletivas, rumo ao ideal de melhoria da qualidade da vida de todos.

$\mathrm{Na}$ busca por uma melhor compreensão dos processos de construção de uma Cultura de Paz em uma sociedade-brasileira-que hoje vemos como sendo caracterizada como bastante violenta, selecionamos a Polícia Militar do Estado X como campo desta pesquisa. Tal escolha ocorreu por duas razões principais: a primeira, por ser a PM a instituição militar responsável por lidar diretamente com questões e ações associadas à violências no contexto da sociedade; a segunda, por ser este o campo de trabalho da pesquisadora, que há 10 anos atua na área da formação e do atendimento psicológico aos membros da instituição. Esta inserção, sem dúvida, foi essencial à realização desta pesquisa. 


\section{CAPÍTULO 3 \\ POLÍCIA MILITAR E CULTURA INSTITUCIONAL}

Neste capítulo, buscamos caracterizar o universo da Polícia Militar, considerando questões institucionais e sua função social, de maneira a possibilitar que o leitor tenha uma compreensão razoável de seu funcionamento. A principal missão da PM pode ser descrita como o policiamento ostensivo e a preservação da ordem pública, buscada diuturnamente através de sua presença $24 \mathrm{~h}$ nas ruas de todo o país. A seguir, vamos conhecer um pouco da sua complexidade.

\section{1 - A Instituição: Missão e Atuação Social}

As instituições militares são milenares e fazem parte da própria história da humanidade. As Forças Armadas (Exército, Marinha e Aeronáutica) são precursoras dos modelos de organização militar em todo o mundo.

Na França da Idade Média, eram os militares que se encarregavam de toda a segurança, interna e externa, sem nenhuma divisão de função. Apenas eram conhecidos como "Marechais" os militares encarregados pelo rei de patrulhar e defender a população contra os salteadores, comuns desde aquela época. A força comandada pelos marechais era chamada de "marechausée", que poderia ser traduzida para marechaleza ou atividade de marechal. Até o Iluminismo do Séc. XVIII, foi esse o cenário da segurança interna francesa.

Com o advento da Declaração dos Direitos do Homem e do Cidadão, em 1789, o artigo 12 deste documento previa a criação de uma "força pública" para a garantia dos direitos formulados na Declaração. Portugal acompanhou essa inovação e criou, em 1801, a Guarda Real de Polícia, inspirada no modelo francês. A vinda da Família Real para o Brasil trouxe essa guarda que, aqui, foi reorganizada, tornando-se a Polícia da Corte (Rio de Janeiro). Após a Independência do Brasil, a Guarda Real foi reorganizada pela Regência em 1831, ano do nascimento das Polícias Militares. Assim, em 15 de dezembro de 1831, por Lei da Assembléia Provincial proposta pelo Presidente da Província, o Brigadeiro Rafael Tobias de Aguiar, foi criado o Corpo de Municipais Permanentes, composto de cem praças a pé e trinta praças a cavalo; eram os "Cento e trinta, de trinta e um". Estava fundada a Polícia Militar do Estado de São Paulo, a primeira do Brasil. ${ }^{1}$

Segundo a Constituição Federal, art. 144, $\S 5^{\circ}$ e $\S 6^{\circ}$ (1988), as Polícias Militares são forças auxiliares reservas do Exército, subordinadas aos governadores dos estados e

\footnotetext{
${ }^{1}$ Fonte: www.wikipedia.org
} 
têm como principal atribuição o policiamento ostensivo e a preservação da ordem pública. Através de sua "missão", busca estabelecer e preservar a paz social nos âmbitos público e privado, através de um atendimento eficaz e eficiente aos cidadãos.

No Estado X a Polícia Militar tem mais de 150 anos de existência, o que a coloca em um patamar de "polícia tradicional", ou seja, já tem suas tradições bem estabelecidas. Tem como missão promover a preservação da ordem pública, a incolumidade das pessoas e do patrimônio, a manutenção da tranquilidade pública e da Paz Social, através do policiamento ostensivo, preventivo e repressivo ${ }^{2}$. Como se pode observar, buscar a paz faz parte explícita da missão desta instituição.

Alguns estudos apontam que toda instituição tem, essencialmente, uma função social. Segundo os estudos de Berger e Berger (1994), algumas características são fundamentais para uma instituição:

- Exterioridade: as instituições são experimentadas como algo dotado de realidade, ou seja, fora do indivíduo;

- Objetividade: alguma coisa é objetivamente real quando todos admitem que de fato a mesma existe;

- Coercitividade: a instituição tem suas regras pré-estabelecidas e o indivíduo deve se adequar a elas;

- Autoridade moral: invocam um direito à legitimidade que lhes garante repreender o indivíduo no terreno da moral;

- Historicidade: em quase todos os fatos experimentados pelo indivíduo, a instituição existia antes de ele nascer e continuará existindo após sua morte.

Uma instituição como a Polícia Militar, que representa o Estado 24h nas ruas, tem uma função social bastante ampla. Além das missões estabelecidas por lei, como mencionado anteriormente, ela pretende ser um modelo de atuação social e formadora de opinião, atuando na educação das pessoas por meio de programas, como, por exemplo, o Programa Educacional de Resistência às Drogas (PROERD). Este é um programa desenvolvido nas escolas públicas e particulares, apenas no $5^{\circ}$ ano e no $7^{\circ}$ ano do Ensino Fundamental, por policiais militares treinados e preparados para desenvolver atividades educativas de natureza lúdica, utilizando metodologias especialmente voltadas para crianças e adolescentes. Recentemente, o PROERD foi adaptado para atender, também, aos pais das crianças, e muitas turmas já foram formadas.

O objetivo do Programa é transmitir uma mensagem de valorização da vida e da importância das pessoas se manterem longe das drogas. Após quatro meses de curso as crianças recebem o certificado PROERD, ocasião em que prestam o compromisso de se

\footnotetext{
${ }^{2}$ Fonte: Assessoria de Comunicação da Polícia Militar do Estado X
} 
manterem afastados e longe das drogas. O Programa é pedagogicamente estruturado em lições ministradas obrigatoriamente por um policial militar fardado que, além da sua presença física em sala de aula como educador social, propicia um forte elo na comunidade escolar em que atua, fortalecendo o trinômio: Polícia Militar, Escola e Família.

A Polícia Militar propõe, ainda, modelos de atendimento eficaz ao cidadão, como o Procedimento Operacional Padrão (POP), e outras ações. Portanto, a PM deve proporcionar uma formação que leve seus integrantes a serem promotores de uma Cultura de Paz na sociedade (Moreira, 2011).

\section{Polícia Comunitária}

Atualmente, tem-se difundido muito no âmbito das Polícias Militares de todo o país a filosofia de Polícia Comunitária, propondo que os policiais estejam preparados para lidar com os problemas cotidianos dos cidadãos comuns de forma preventiva, e não somente coerciva, como há anos se fazia. A Polícia Comunitária é uma filosofia de trabalho fundamentada, principalmente, numa parceria entre a população e as instituições de Segurança Pública e Defesa Social. Segundo Trojanowicz e Bucqueroux (1994), a Polícia Comunitária é uma estratégia organizacional que proporciona uma nova parceria entre a população e a polícia. Baseia-se na premissa de que tanto a polícia quanto a comunidade devem trabalhar juntas para identificar, priorizar e resolver problemas contemporâneos tais como crimes, desordens físicas e sociais, com o objetivo de melhorar a qualidade de vida geral das pessoas que vivem em determinada área, melhorando, assim, a qualidade de vida dos cidadãos.

A primeira imagem que se tem da polícia é, certamente, formada na família. $O$ policial junto à comunidade, além de garantir a segurança, deverá exercer uma função didático-pedagógica visando orientar a educação das pessoas no sentido da solidariedade social. A ideia central da Polícia Comunitária reside na possibilidade de propiciar uma aproximação entre os profissionais de segurança pública e a comunidade onde atuam. Para isto, deve desenvolver um trabalho sistemático, planejado e detalhado.

No Curso Nacional de Promotor de Polícia Comunitária (2008), por exemplo, foram discutidos alguns tópicos relativos à imagem do policial, sendo este uma referência muito cedo internalizada entre os componentes da comunidade. O medo da polícia, erroneamente transmitido na família e, às vezes, na mídia, pode ser revertido desde que o policial se faça perceber por sua ação protetora e amiga. A proposta de uma polícia trabalhando em conjunto com a sociedade reforça a atuação social da instituição, que ganha credibilidade e parcerias para melhor realizar o trabalho preventivo. 


\section{2 - Valores da/na Cultura Militar}

O ingresso na carreira policial militar tem origem em diversas motivações, que vão desde um sonho de criança até a busca por um emprego estável e uma carreira consolidada. Ao observar esse processo de ingresso, formação e atuação dos policiais militares, algumas reflexões se tornam pertinentes e necessárias.

A carreira na Polícia Militar inicia-se por duas vias: Curso de Formação de Praças (CFP) e Curso de Formação de Oficiais (CFO). A carreira das praças segue a seguinte hierarquia: aluno-soldado, soldado (a partir da formatura no CFP), cabo, $3^{\circ}$ sargento, $2^{\circ}$ sargento, $1^{\circ}$ sargento, subtenente. A carreira dos oficiais segue a seguinte hierarquia: cadete ou aluno-oficial, aspirante a oficial (a partir da formatura no CFO), $2^{\circ}$ tenente, $1^{\circ}$ tenente, capitão, major, tenente-coronel e coronel. Recentemente foi implantado um novo programa para reforçar a Segurança Pública do Estado X, o Simve (Serviço de interesse militar voluntário estadual). São voluntários reservistas do Exército Brasileiro, recrutados por meio de seleção, que recebem um curso de formação de três meses e podem ficar na instituição por até três anos. É um serviço temporário, remunerado, mas que não tem uma carreira na Polícia Militar. Seu grau de hierarquia corresponde ao de soldado.

O "civil" ou "paisano", como é comumente nomeada a pessoa que não é militar, chega à Polícia Militar com sua trajetória de vida, sua história, sua formação acadêmica ${ }^{3}$ e sua "cultura pessoal" (Valsiner, 2012). Ao iniciar o curso de formação, essa pessoa se defronta com uma instituição que tem história, normas, tradições e uma "cultura coletiva" (Valsiner, 2012). Vamos aqui nomeá-la como "cultura militar" (Moreira, 2011). Então, a pessoa deixa de ser um "civil" e passa a ser um "policial militar", o que provoca várias mudanças comportamentais e uma reconfiguração de identidade, já a partir dessa fase de formação.

Podemos identificar três grupos formados no contexto da Polícia Militar em relação a essa dualidade, "cultura pessoal versus cultura coletiva". O primeiro grupo é composto de pessoas que se adaptam muito bem à cultura militar; desenvolvem o sentimento de pertença e autorrealização. O segundo, são pessoas que não se adaptam à cultura militar, sentem-se decepcionadas e frustradas, e pedem desligamento ainda na fase de formação. E o terceiro grupo, são pessoas que, apesar de decepcionadas e frustradas com a cultura militar, são persistentes, não pedem desligamento e levam essa insatisfação para suas práticas. Felizmente, ao que nos parece (observação empírica sem dados científicos) tudo indica que o primeiro grupo compõe a maioria dos policiais militares e se sobressai perante os demais.

\footnotetext{
${ }^{3}$ No Estado X, é exigido curso superior para ingresso na Polícia Militar, via concurso público, tanto no Curso de Formação de Praças, quanto no Curso de Formação de Oficiais. Este último, é restrito aos Bacharéis em Direito.
} 
No Curso de Formação de Oficiais (CFO) constata-se que as transformações sociais e os interesses individuais a cada ano têm alterado o perfil dos indivíduos que ingressam na carreira de Oficial da Polícia Militar. A exigência em ser Bacharel em Direito, no Estado X, veio delimitar esse perfil, o que também modificou as motivações, expectativas e valores que os Cadetes (assim são chamados os alunos do CFO) apresentam em relação à carreira.

Os valores da cultura militar são disseminados e coconstruídos tanto por meio de disciplinas que compõem a grade curricular do CFO, quanto por atividades complementares, que envolvem solenidades, formaturas militares e o "currículo oculto", ou seja, conteúdos implícitos transmitidos ao longo da formação (Branco, 1993). As expectativas e crenças, posicionamentos e coconstrução de valores, bem como conflitos internos e externos que surgem nesse período de adaptação, apresentados por cadetes e tenentes recém-formados, serão investigados e analisados neste estudo.

$\mathrm{Na}$ pesquisa de Wortmeyer (2007) com Cadetes da AMAN (Academia Militar dos Agulhas Negras - Curso de Formação de Oficiais do Exército Brasileiro), a autora considera que:

"é através da internalização do Etos militar que o cadete forjará sua identidade profissional; é pela assimilação de valores, símbolos, discursos e padrões de conduta típicos da cultura militar que o jovem se capacitará, de fato, ao desempenho de seu papel na organização" (p. 19).

Os valores da instituição em análise-PM do Estado $X$-estão estabelecidos no Art. $6^{\circ}$ do Código de Ética da Polícia Militar do Estado X, estabelecidos no Decreto $n^{\circ}$ 1.642, de 28 de agosto de 2000. São eles ${ }^{4}$ :

- Patriotismo: revelado no amor e dedicação à Pátria;

- Civismo: através do culto aos símbolos e tradições da Pátria, das Polícias Militares, além da dedicação ao interesse público;

- Hierarquia: traduzida no respeito e valorização dos postos e graduações;

- Disciplina: significando exato cumprimento do dever e essencial preservação da ordem pública;

- Profissionalismo: pelo exercício da profissão com entusiasmo e perfeição;

- Lealdade: manifestada pela fidelidade aos compromissos para com a Pátria, Polícias Militares, e aos superiores hierárquicos;

- Constância: como firmeza, ânimo e fé nas Polícias Militares;

- Espírito de corpo: orgulhando-se de suas Instituições, mediante identificação legítima entre seus componentes;

\footnotetext{
${ }^{4}$ Fonte: Polícia Militar do Estado X
} 
- Honra: como busca legítima do reconhecimento e consideração, tanto interna quanto externamente, às Polícias Militares;

- Dignidade: respeitando a si próprio e aos seus semelhantes, indistintamente;

- Honestidade: através da probidade, tanto no exercício da função pública quanto na vida particular;

- Coragem: demonstrando destemor ante o perigo e devotando-se à proteção de pessoas, do patrimônio e do meio ambiente.

Esses valores são amplamente difundidos nos cursos de formação e durante toda a carreira do policial militar. São valores e crenças da cultura militar que terminam por serem internalizados pelos indivíduos em diferentes graus, transformando-se, com o tempo, em uma cultura que pode ser caracterizada como militarismo (Moreira, 2011). Em síntese, a construção de práticas e significados que constituem a cultura militar são consequências do processo histórico e sociocultural de adaptação da instituição Polícia Militar às exigências de sua atividade fim, definida e cobrada por sua função social.

A seguir, apresentamos a proposta atual de formação de oficiais da PM com base na Matriz Curricular adotada pelo comando da Academia de Polícia Militar do Estado X.

\section{3 - A Formação de Oficiais na Polícia Militar}

O Curso de Formação de Oficiais (CFO) é o contexto, ou momento, em que se prepara o policial militar no Quadro de Oficiais da PM para comandar. Seu objetivo formal é que o cadete passe a ser sujeito de sua própria formação, assumindo sua responsabilidade como participante de uma Instituição de Segurança Pública, consciente de seu papel de "líder social" junto à comunidade em que exerce sua função.

A proposta do CFO integra conhecimentos teóricos e práticos em sala de aula, nas dependências da Academia de Polícia Militar, na capital do Estado X. O curso tem a duração de dois anos, divididos em três períodos de oito meses cada um, sendo o último mês de cada período destinado ao Estágio Operacional, realizado nas unidades operacionais da capital. A grade curricular com as disciplinas está em fase de reestruturação e são totalmente articuladas com os eixos e áreas temáticas.

Os instrutores do CFO são todos Oficiais da Polícia Militar ou Bombeiros Militares, Peritos e Delegados de Polícia, convidados a ministrar aula pela sua área específica de conhecimento e atuação. Os instrutores recebem remuneração extra-salário dependendo do grau de instrução que possuem (da graduação ao doutorado).

A Matriz Curricular do CFO tem como objetivo impulsionar, por meio de processos educacionais, a análise e a discussão das necessidades de transformação dos conhecimentos sobre Segurança Pública a partir das demandas atuais da sociedade, bem como das demandas profissionais da área policial. Tem por objetivo identificar e 
propor estratégias concretas de realização e aprimoramento do processo de formação do Chefe de Polícia Ostensiva (Oficial) da Polícia Militar do Estado $X^{5}$.

A Matriz Curricular do CFO propõe um conjunto de orientações voltadas para o desenvolvimento de ações formativas, a partir do diálogo entre princípios fundamentais, eixos articuladores e áreas temáticas. Os princípios que fundamentam a concepção de formação profissional do Oficial adotados pela Polícia Militar do Estado X são:

a) compreensão e valorização das diferenças;

b) formação e qualificação profissional continuada;

c) flexibilidade, diversificação e transformação;

d) interdisciplinaridade, transversalidade e reconstrução democrática de saberes;

e) valorização do conhecimento anterior;

f) valorização do conhecimento da realidade;

g) universalidade;

h) articulação, continuidade e regularidade;

i) qualidade e atualização permanente.

Os eixos articuladores selecionados para orientar o currículo de formação do Oficial são:

(a) Sujeito e Interações no contexto da Segurança Pública - este eixo articulador se justifica pela necessidade de considerar o Oficial como sujeito que desenvolve sua função em interação permanente com outros e com o ambiente, tornando essencial articular os conteúdos formativos, a questões sobre as diferentes concepções acerca do indivíduo, os papéis por ele desempenhados e a qualidade das interações que estabelece. Cabe discutir os valores a respeito de si mesmo e das relações estabelecidas no contexto do exercício da sua profissão, permitindo que processos educativos sejam vivenciados e entendidos como momentos de interação, de encontro e de discussão de temas diretamente ligados a este eixo;

(b) Sociedade, Poder, Estado, Espaço Público e Segurança Pública - é o eixo que traduz a exigência de considerar as atividades de Segurança Pública no contexto da sociedade, no local onde elas se dão, oferecendo a possibilidade de conhecer e refletir sobre a realidade social, sua organização e suas tensões estudadas do ponto de vista histórico, social, político, antropológico e cultural; sobre conceitos políticos fundamentais como "Democracia" e "Estado de Direito", considerando igualmente as questões referentes à convivência no espaço público (local principal da atuação da Polícia Militar e da coexistência de interesses e intenções conflitantes);

\footnotetext{
${ }^{5}$ Fonte: Matriz Curricular 2014, da Academia de Polícia Militar do Estado X.
} 
(c) Ética, Cidadania, Direitos Humanos e Segurança Pública - este eixo articulador visa estimular o desenvolvimento de conhecimentos, práticas e atitudes relativas à dimensão ética da existência, da prática profissional e da vida social, pela importância da reflexão sobre as articulações entre as diferentes noções de ética, cidadania e Direitos Humanos, bem como suas implicações nos diferentes aspectos da vida profissional e institucional no contexto das atribuições da PM e sobre os diversos conteúdos formativos, inclusive os de caráter técnico e operacional, enfatizando a dimensão ética da existência, buscando a tradução concreta de princípios e valores na prática cotidiana profissional;

(d) Diversidade, Conflitos e Segurança Pública - este eixo articulador trata da discussão de questões que dizem respeito à diversidade que caracteriza o espaço social e cultural. A diversidade é proposta como fonte permanente de enriquecimento e desafio, cabendo proporcionar ao Oficial, instrumentos para conhecer e refletir sobre expressões da diversidade e do conflito como fenômenos inerentes à vida social e às relações humanas. Este eixo estimula a reflexão permanente sobre as intervenções da PM frente às questões de diferença sociocultural, gênero, orientação sexual, etnia, geração, comportamentos estigmatizados e, especialmente, daquelas que se tornam geradoras de conflitos marcados por intolerância e discriminação.

As áreas temáticas contemplam os conteúdos indispensáveis à formação do Oficial, além de capacitá-lo para o exercício de sua função. Na Matriz Curricular do CFO foram adotadas oito áreas temáticas destinadas a acolher um conjunto de conhecimentos que são tratados nas disciplinas do curso:

(a) Sistemas, instituições e gestão integrada em Segurança Pública - esta área temática possibilita a compreensão das estruturas organizacionais da história e da dinâmica das Instituições de Segurança Pública dos diversos sistemas existentes. Inclui a discussão crítica e contextualizada da atuação dos diferentes órgãos e carreiras profissionais, que compõem as organizações responsáveis pela promoção e preservação da ordem pública, destacando as competências, os pontos de articulação existentes, as interfaces e a interatividade das respectivas ações, com vistas a instrumentalizar o Oficial para a participação no desenvolvimento das políticas integradas de Segurança Pública. Propõe estimular o conhecimento dos fatores sociais que afetam a atuação das organizações de Segurança Pública e, mais amplamente, do Sistema de Justiça Criminal para a compreensão de sua inserção no sistema e para a análise histórica e crítica das questões relativas às políticas públicas de segurança e ao conceito de Segurança Pública.

(b) Violências, crime e controle social - esta área temática estabelece um espaço de conhecimento crítico e de reflexão sobre os fenômenos da violência e do crime em suas várias formas, proporcionando a compreensão das diversas maneiras da sociedade organizar (ou não) o controle dessas manifestações. Isto inclui o entendimento da 
diferença entre a modalidade jurídico-penal de tratar a violência e outras modalidades, bem como a abordagem interdisciplinar da violência e da criminalidade.

(c) Cultura e conhecimento jurídico - esta área temática propicia a reflexão crítica sobre o Direito como construção cultural sobre os Direitos Humanos e sua implementação, com vista à atuação profissional do Oficial no Estado Democrático de Direito. Isto implica no conhecimento do ordenamento jurídico brasileiro, seus princípios e normas, com destaque para a legislação pertinente às atividades policiais, de forma não dissociada das demais perspectivas de compreensão da realidade, tanto no processo formativo quanto na prática profissional.

(d) Modalidades de gestão de conflitos e eventos críticos - esta área temática propõe favorecer o domínio do conhecimento e das modalidades necessárias para lidar com situações de conflito, considerando que estas são diversificadas e que demandam procedimentos e técnicas diferenciadas de atuação preventiva e reativa. Isto inclui o estudo de técnicas de mediação, negociação e uso progressivo da força, entre outras. Dada a complexidade das situações de conflito, é fundamental que sejam considerados o foco, o contexto e os envolvidos, para que as decisões sejam tomadas de forma responsável, eficaz, legítima e legal. A análise das situações de conflito deve ser realizada no interior dos grupos, incentivando o desenvolvimento de equipes, o planejamento integrado e o comportamento assertivo, com aplicação das táticas de gerenciamento de conflitos. Tomando sempre como base a análise e cumprimento do Procedimento Operacional Padrão (POP) da PM.

(e) Valorização profissional e saúde do trabalhador - a abordagem desta área temática é urgente e determinante quanto à motivação, à eficácia e ao bem-estar do Policial Militar, incluindo metodologias que valorizem os participantes e lhes permitam ter uma imagem positiva de si como sujeito e como membro da instituição. Tem por objetivo contribuir para a criação de uma cultura efetiva de respeito e bem-estar dos profissionais, não se restringindo a questões relacionadas à remuneração e planos de carreira, mas também a condições de trabalho, equipamentos disponíveis e acesso às atividades de formação. $A$ saúde do trabalhador está associada a sua valorização, tendo como referência a dimensão física e os aspectos psicológicos e sociais da vida profissional. Esta área temática inclui, ainda, a valorização e a proteção da vida e da integridade física, mental e emocional do Policial Militar, referindo-se à adoção de providências técnicas e a modalidades específicas de organização do trabalho e ao estudo do estresse e de suas consequências.

(f) Comunicação, informação e tecnologias em Segurança Pública - esta área temática inclui conteúdos relativos aos princípios, procedimentos e técnicas da comunicação, isto é, dos processos de troca e transferência de informação. É imprescindível para o Oficial 
conhecer e utilizar de maneira eficaz, legal e eticamente sustentável, o complexo sistema de comunicação que constitui e estrutura o próprio Sistema de Segurança Pública. Esta área inclui a abordagem geral dos diferentes princípios, meios e modalidades de comunicação, destacando-se entre eles a comunicação verbal e não verbal fundamental para a interação com o público, a comunicação escrita e a comunicação de massa, designando as diversas técnicas de difusão de informação, ligadas ao progresso técnicocientífico, destinadas ao conjunto da sociedade.

(g) Cotidiano e prática policial reflexiva - esta área temática propõe a realização de atividades formativas centradas na discussão teórica da prática e da realidade cotidiana da profissão, preparando para a mobilização, em tempo real, do conjunto de conhecimentos para solução e mediação de problemas concretos.

(h) Funções, técnicas e procedimentos em Segurança Pública - trata-se da área temática em que se concentram os conteúdos relativos aos aspectos técnicos e procedimentais inerentes do exercício das funções e que devem permear as ações formativas e integrar as demais áreas temáticas. Correspondendo à concretização final de todo o processo de formação destinado a instrumentalizar o Oficial para o desempenho de sua função. $A$ qualidade deste desempenho está, desta maneira, vinculada aos conhecimentos, competências, habilidades e atitudes contemplados pelas demais áreas temáticas.

As informações contidas na Matriz Curricular do CFO nos permitem observar que o currículo formal é abrangente, atual, e busca interface com outras áreas do conhecimento, como Sociologia, Antropologia, Psicologia, Comunicação, além do Direito. Apesar de não ser o objetivo principal desta pesquisa, temos como desafio identificar e analisar alguns aspectos do currículo oculto presente nas práticas cotidianas vivenciadas pelos cadetes, e compreender de que forma este currículo pode influenciar os posicionamentos, crenças e os valores dos cadetes, especialmente em relação à temática da Paz e da Violência.

Em resumo, o objetivo, ou foco deste estudo, consiste em compreender como cadetes em processo de formação na PM e tenentes já formados, com dois anos de práticas e vivências cotidianas no ambiente da Polícia Militar, se posicionam em relação a valores e dilemas relativos a questões de Paz e Violência. Buscamos, especialmente, explorar como estes posicionamentos podem ter sido promovidos (ou não) pelo próprio CFO. Vale lembrar que os participantes dessa pesquisa não tinham experiência militar antes do CFO, ou seja, eram "civis". Assim sendo, todos os participantes estão tendo, ou tiveram, o seu primeiro contato com a cultura militar a partir do referido curso, o que nos possibilita investigar os prováveis impactos promovidos, ou suscitados, pela formação na APM. Os objetivos da pesquisa são apresentados a seguir. 


\section{PARTE II}

\section{OBJETIVOS}

\section{Objetivo Geral}

Identificar e analisar conceitos, crenças, valores e posicionamentos dos participantes em relação a questões referentes à violência e à paz no contexto da sociedade e da Polícia Militar, tendo em vista o desenvolvimento de práticas orientadas para a formação de oficiais do quadro operacional da Polícia Militar como agentes na construção da paz. A partir do estudo, pretende-se contribuir para que os cursos de formação de oficiais possam ser aperfeiçoados no sentido de proporcionar maior qualificação para lidar com conflitos e situações de violência, tornando-os agentes proativos na construção de uma Cultura de Paz na sociedade.

\section{Objetivos Específicos}

1. Identificar e analisar, com base nas narrativas de Cadetes e Tenentes do Quadro Operacional da PM do Estado $X$, seus conceitos, crenças, valores, posicionamentos, práticas e expectativas relacionadas à paz, ao conflito, à violência e à atuação da Polícia Militar diante destas questões;

2. Identificar e analisar, com base nas narrativas do coordenador e da instrutora do Curso de Formação de Oficiais (CFO), responsável pela disciplina Polícia Comunitária, seus conceitos, crenças, valores, posicionamentos, práticas e expectativas relacionadas à paz, ao conflito, à violência e ao papel da Polícia Militar diante destas questões;

3. Analisar, com base nas narrativas produzidas pelos participantes, as características do Curso de Formação de Oficias da PM do Estado X que podem atuar no sentido de promover conceitos, crenças, valores, posicionamentos e práticas específicas relacionadas à violência e à construção da paz. 


\section{PARTE III}

\section{METODOLOGIA}

\section{1 - Abordagem Metodológica}

Os estudos qualitativos que procuram analisar a estrutura e a dinâmica dos processos de desenvolvimento revelam-se como a abordagem metodológica mais adequada para desvendar relações significativas. Tais relações adquirem, então, um especial sentido na interpretação dos fenômenos psicológicos que emergem entre as pessoas e seus contextos específicos (Camic, Rhodes \& Yardley, 2002; Yokoy, Branco \& Lopes de Oliveira, 2008).

Segundo Branco e Valsiner (1997), na pesquisa qualitativa, as etapas se definem mutuamente à medida que o processo avança, resultando no "ciclo da metodologia", assim denominado pelos autores. Os autores afirmam que as diferentes etapas do ciclo metodológico precisam ser consideradas em conjunto, revelando coerência e consistência. Assim, a metodologia aqui empregada, de caráter qualitativo (Bauer \& Gaskell \&, 2002), buscou contemplar estas exigências e revelou-se bastante adequada ao alcance dos nossos objetivos.

\subsection{1 - Entrevista como processos de significação}

Segundo González-Rey (2005), instrumento é toda situação ou recurso que permite ao outro expressar-se no contexto de relação que caracteriza a pesquisa. No caso da entrevista, trata-se de um procedimento que pode adotar instrumentos específicos como roteiro de questões e outros facilitadores da fala do sujeito. Assim, procedimentos e instrumentos de pesquisa devem ser compreendidos como formas diferenciadas de expressão das pessoas e representam uma via legítima para estimular a reflexão e a construção do sujeito. Afinal, toda resposta é inseparável da pergunta e da carga subjetiva, tanto de quem a formula como de quem a responde. Na pesquisa qualitativa, procedimentos e instrumentos não são vistos como um fim em si mesmo, capazes de assegurar a validade da pesquisa, mas se tornam uma ferramenta interativa entre investigador e investigado (González-Rey, 2005; Valsiner, 2007).

Segundo Branco e Madureira (2001), na investigação qualitativa, a entrevista ganha um espaço legítimo na produção de novos conhecimentos na psicologia pois, consiste em uma ferramenta interativa que adquire sentido dentro de um espaço dialógico, em que o estabelecimento do vínculo entre o pesquisador e os sujeitos investigados cumpre uma função essencial na qualidade dos indicadores produzidos. As autoras ressaltam que os significados coconstruídos no momento dialógico da entrevista 
não adquirem sentido, por si só, mas a partir da integração realizada pelos pesquisadores, entre os objetivos da pesquisa, e a perspectiva epistemológica e teórica adotada.

Nesse sentido, a entrevista semiestruturada, enquanto um recurso metodológico, é adequada à investigação da temática proposta neste estudo, uma vez que possibilita uma interface entre os diversos assuntos que permeiam o tema, bem como permite explorar amplamente conceitos, valores e posicionamentos dos participantes em relação às questões relativas à violência e à paz. Além disso, durante o procedimento de entrevista, foram utilizadas como recurso para estimular a discussão, reflexão e a narrativa dos sujeitos, imagens, vídeo e dilemas da vida real relacionados às questões de violência e de paz investigadas neste trabalho, o que favoreceu narrativas mais ricas por parte dos sujeitos.

\subsection{2 - Grupo Focal como espaço dialógico para a investigação}

O grupo focal é um recurso metodológico que pode ser utilizado buscando compreender os diferentes posicionamentos, percepções e atitudes dos participantes acerca de uma situação, fato ou tema. A essência do grupo focal consiste justamente na interação entre os participantes e o pesquisador, com o objetivo de produzir indicadores a partir da discussão focada em tópicos específicos.

Segundo Wilkinson (2008), o grupo focal é uma técnica relativamente nova e popular, muito utilizada como método nas pesquisas qualitativas em Ciências Sociais. São grupos de discussão que dialogam sobre um tema em particular, ao receberem estímulos apropriados para o debate. Essa técnica distingue-se por suas características próprias, principalmente pelo processo de interação grupal, que é uma resultante da construção de informações. Em uma vivência de aproximação, permite que o processo de interação grupal se desenvolva, favorecendo trocas, descobertas e participações comprometidas e, evidentemente, a coconstrução de significados.

Segundo os estudos do referido autor, no grupo focal o pesquisador funciona como um moderador para o grupo apresentando questões sobre o tema, mediando discussões e encorajando as pessoas a participarem abertamente. Também deve explorar como os fatos são articulados, censurados, confrontados e alterados por meio da interação grupal e, ainda, como isto se revela através da comunicação das pessoas.

Essa técnica facilita a formação de ideias novas e originais, e gera possibilidades contextualizadas pelo próprio grupo. Oportuniza a interpretação de crenças, valores, conceitos, conflitos, confrontos e pontos de vista e, ainda, possibilita entender como o tema proposto é visto e avaliado nas situações da vida cotidiana. Também pode ser 
associado a outros instrumentos na busca por indicadores empíricos, sendo apropriado para o estudo do tópico abordado nesta pesquisa.

\section{2 - Método}

\subsection{1- Contato com a Polícia Militar do Estado onde se realizou a pesquisa}

$\mathrm{O}$ contato com a Polícia Militar do Estado $\mathrm{X}$ foi feito diretamente com 0 Comandante Geral da corporação, a quem foram explicados os objetivos e as motivações da pesquisa. Prontamente ele se interessou pela realização do estudo e assinou o Termo de Ciência e Autorização, que possibilitou a submissão ao Comitê de Ética e, posteriormente, o contato e o convite aos participantes.

\subsection{2- Participantes}

Participaram deste estudo 12 (doze) policiais militares: 05 (cinco) Cadetes (alunos do Curso de Formação de Oficiais - CFO); 05 (cinco) Tenentes recém-formados; todos pertencentes ao Quadro Operacional da PM. No entanto, das cinco entrevistas de cada categoria, foram selecionadas e analisadas três de cada grupo, devido à necessidade de um recorte para este trabalho. Todos os participantes eram egressos de vida civil, ou seja, não tiveram nenhum contato com a formação militar anteriormente ao ingresso no CFO, o que estabelecemos como critério para melhor observar os possíveis impactos do CFO em suas formações. Cada grupo contou com a participação de uma mulher, considerando que são minoria na PM (hoje, apenas 10\% das vagas para ingresso na carreira são direcionadas a elas). Também participaram deste estudo o Capitão coordenador do CFO e a Capitão instrutora da disciplina Polícia Comunitária, por ter sido esta a mais referenciada pelos alunos, devido ao conteúdo programático envolvendo a temática da Paz e da Violência no âmbito da formação do oficial. Todos os nomes aqui utilizados são fictícios para preservar o anonimato dos participantes. 
Tabela 1 - Informações sobre os oficiais participantes da pesquisa

\begin{tabular}{|l|c|c|c|c|}
\hline \multicolumn{1}{|c|}{ Nome Fictício } & Idade & Tempo na instituição & Filhos & Escolaridade / Formação \\
\hline Cadete Moisés & 25 & 3 meses & 0 & Bacharel em Direito \\
\hline Cadete Ester & 30 & 3 meses & 0 & Bacharel em Direito \\
\hline Cadete Davi & 25 & 3 meses & 0 & Bacharel em Direito \\
\hline Tenente Gabriel & 31 & 4 anos & 1 & Bacharel em Direito \\
\hline Tenente Suzana & 29 & 4 anos & 0 & Bacharel em Direito \\
\hline Tenente Jonas & 29 & 4 anos & 0 & Bacharel em Direito \\
\hline $\begin{array}{l}\text { Capitão Rafael } \\
\text { (coordenador) }\end{array}$ & 39 & 20 anos & 2 & Bacharel em Direito \\
\hline $\begin{array}{l}\text { Capitão Ana } \\
\text { (instrutora) }\end{array}$ & 36 & 12 anos & 2 & Bacharel em Direito \\
\hline
\end{tabular}

Obs: Os cadetes pertenciam à última turma que ingressou no CFO, no final de 2014. Os tenentes pertenciam à última turma formada pela APM, no final de 2012. Não houve outra turma nesse intervalo.

\subsection{3- Local}

A pesquisa foi realizada no contexto da Polícia Militar do Estado X, na Academia da PM, onde acontece o CFO, e nos Batalhões Operacionais da capital do Estado, onde os tenentes recém-formados estavam atuando.

\subsection{4- Materiais e equipamentos}

Foram utilizados como instrumentos de investigação roteiros para a realização das entrevistas semiestruturadas individuais (anexo 1), impressos em papel A4, bem como um gravador digital de áudio. Durante as entrevistas e o grupo focal foi utilizado um notebook, no qual foram mostradas as imagens e vídeo selecionados para a realização da pesquisa. Nas sessões de grupo focal foi utilizado um roteiro semiestruturado impresso, uma filmadora digital com tripé e um gravador digital de áudio. Em anexo, encontram-se os roteiros das entrevistas e das duas sessões de grupo focal.

\subsection{5- Procedimentos}

O projeto foi submetido ao Comitê de Ética e Pesquisa da Universidade de Brasília para aprovação. Após aprovação foram seguidos os seguintes passos:

1. Entrevistas individuais com cinco Cadetes;

2. Uma sessão de Grupo Focal com cinco Cadetes;

3. Entrevistas individuais com cinco Tenentes;

4. Uma sessão de Grupo Focal com três Tenentes;

5. Entrevista individual com o capitão coordenador do CFO; 
6. Entrevista individual com a capitão instrutora da disciplina Polícia Comunitária;

7. Observação de atividades extracurriculares anotadas em um diário de campo.

Os policiais militares foram convidados a participar do estudo buscando uma amostra de conveniência, com a inclusão de uma mulher em cada grupo. Foram explicados, de forma minuciosa, os objetivos da pesquisa, a questão do sigilo e a finalidade acadêmica. Após todos aceitarem, foram agendadas as entrevistas individuais, e assinados os Termo de Consentimento Livre e Esclarecido (TCLE) e o Termo de Cessão e Uso de Imagem.

\subsubsection{1 - Entrevistas Individuais Semiestruturadas.}

Com o grupo dos cadetes, as cinco entrevistas individuais foram previamente agendadas e realizadas nas dependências da Academia da Polícia Militar (APM), em uma sala reservada destinada ao Serviço de Psicologia.

As entrevistas com os tenentes foram previamente agendadas, e assim realizadas: três em salas reservadas nos Batalhões onde eles estavam empregados; e duas na sala da APM destinada ao Serviço de Psicologia.

A entrevista com o coordenador do CFO foi realizada em sua sala reservada, nas dependências da APM, seguindo um roteiro semiestruturado próprio (anexo 3). A entrevista com a instrutora da disciplina Polícia Comunitária foi realizada em sala reservada em seu local de trabalho fora da APM, seguindo um roteiro semiestruturado próprio (anexo 4).

As entrevistas com os cadetes e tenentes foram compostas de questões abertas sobre a temática da violência e da paz, e questões sobre o curso de formação. Ao final, foram mostradas quatro imagens com conteúdo de violência, envolvendo civis e policiais militares. Após a apresentação de cada imagem, foi perguntado ao participante sobre o "sentimento" a respeito. Cópia das imagens constam no anexo 9.

As imagens foram, assim, apresentadas aos Cadetes e Tenentes:

Imagem 1 - Civil chutando o rosto de um policial militar;

Imagem 2 - Policiais militares agredindo um civil;

Imagem 3 - Coronel da PM agredido em uma manifestação;

Imagem 4 - Policiais fazendo contenção de um civil em manifestação.

Na sequência, foi apresentado um vídeo de curta duração, com aproximadamente quatro minutos. O vídeo mostra uma grande confusão com a presença da PM em uma manifestação popular de cunho político, na qual as pessoas reivindicavam a saída do governador do Estado X. As imagens mostram policiais militares pichados em amarelo, sendo xingados de "covardes", "repressores", e "cachorros do governo" por populares. 
São também acusados de estarem "defendendo" o governo. A partir de pesquisa realizada sobre essa ação, constatou-se que a manifestação era pacífica e a PM foi instruída apenas a acompanha-la; fizeram intervenção para conter a depredação de um prédio público, quando se iniciou a revolta popular mostrada no vídeo.

\subsubsection{2 - Grupo Focal.}

Foram realizadas duas sessões de grupo focal, sendo uma com cada categoria. Participaram do primeiro grupo cinco cadetes entrevistados individualmente e, no segundo grupo, três dos tenentes entrevistados. O mesmo roteiro semiestruturado foi utilizado para os dois grupos focais (anexo 2), sendo proposta a mesma atividade envolvendo os dilemas "A história de Maria" e "A bomba e o policial militar".

A sessão do grupo focal dos Cadetes foi realizada na sala de convivência dos cadetes na APM, utilizando uma ampla mesa redonda. O grupo focal dos Tenentes foi realizado na sala reservada do Serviço de Psicologia, também com cadeiras em círculo, contando com a participação de apenas três tenentes. Um dos participantes desmarcou na véspera, e o outro teve uma ocorrência policial e não chegou a tempo.

A história de Maria foi assim relatada em ambas as sessões de grupo focal:

\section{A história de Maria}

“MARIA era casada com JOÃO e eles se amavam. Eles moravam num morro onde atuavam duas gangues de bandidos, mas o casal vivia honestamente. O morro era dividido pelas gangues, que protegiam os moradores, mas brigavam demais entre si. Depois de um certo tempo, JOÃO começou a chegar cada vez mais tarde em casa, e não ligava mais para a mulher. MARIA se sentiu abandonada e procurou PAULO, que morava do outro lado do morro. MARIA voltava para casa sempre antes do marido chegar. Num dia, quando voltava, ela viu que os BANDIDOS daquela gangue estavam atacando as pessoas que passavam pela única ponte que separava as duas partes do morro. Ela correu de volta para a casa de PAULO e pediu proteção. Ele respondeu que não poderia ajudá-la e que o problema era dela. Ela, então procurou um AMIGO. Este foi com ela até a ponte, mas acovardou-se diante da presença dos bandidos da gangue, e não teve coragem de enfrentá-Ios. MARIA, então, resolveu procurar o único TAXISTA que trabalhava ali. Este aceitou levá-la por outro caminho, mas isso iria Ihe custar R\$80,00. MARIA, porém, não tinha dinheiro. Insistiu e implorou, mas o TAXISTA foi irredutível. Ela resolveu, então, arriscar e passar pela tal ponte, mas os bandidos a pegaram e bateram nela até a morte". 
O dilema sobre a bomba e o policial foi, em seguida, apresentado e discutido no grupo focal. Segue o relato:

\section{A Bomba e o Policial Militar}

"Você é um policial militar que acaba de capturar um assassino acusado de colocar bombas em locais públicos. Seus crimes já causaram a morte de muitas pessoas. Porém, o Bandido afirma que, antes de ser preso, ele já havia colocado uma bomba em um local e se nega a revelá-lo. Vocês temem que essa bomba possa ser detonada, matando milhares de pessoas. O que vocês fariam para conseguir essa informação? No caso dele se recusar a dar a informação, o que mais poderia ser feito?"

Após a apresentação e discussão das histórias-dilema, algumas questões abertas a respeito da "Cultura Militar" também foram propostas (anexo 2), visando provocar discussões e reflexões a respeito do tema investigado. Como dito anteriormente, foram atribuídos nomes fictícios a todos os participantes no contexto da pesquisa, garantindo o anonimato.

\subsection{6- Procedimento de análise}

Após a transcrição integral das entrevistas individuais, gravadas em áudio, e dos vídeos das sessões de grupo focal, iniciamos uma análise construtivo-interpretativa dos indicadores empíricos obtidos, tendo em vista o processo de construção dos conhecimentos necessários ao alcance dos objetivos da pesquisa. Gaskins, Miller e Corsaro (1992) afirmam que a análise interpretativa constitui uma oportunidade para descobrir a natureza e o significado dos processos socioculturais, bem como as mudanças que podem ocorrer com o desenvolvimento dos participantes nos diferentes contextos. Consideramos que este tipo de análise constitui uma oportunidade de investigar os significados construídos pelos participantes no contexto da pesquisa. $A$ partir das transcrições, as narrativas foram segmentadas em trechos onde os significados, especificamente relacionados ao tema e objetivo da pesquisa, foram identificados, para efeito de análise dos conceitos, valores e posicionamentos dos Oficiais da PM acerca da temática paz e violência.

\subsection{7 - Custo / Benefício}

Este projeto de pesquisa prezou pelo anonimato total dos participantes, bem como pela confidencialidade das informações aqui prestadas, estando sob responsabilidade da pesquisadora o arquivamento do material após a realização da pesquisa. Vale ressaltar que o fato da pesquisadora ser membro da corporação foi fundamental para a obtenção 
das informações necessárias e um grande fator facilitador, pois permitiu gerar um nível alto de confiança entre os participantes da pesquisa, bem como compreender os termos e linguagens militares por eles utilizados. 


\section{PARTE IV}

\section{RESULTADOS}

Com o objetivo de analisar os dados construídos na pesquisa destacamos trechos das entrevistas individuais semiestruturadas realizadas com os Cadetes e com os Tenentes. O mesmo foi feito nas análises dos grupos focais realizados com cada categoria, buscando, em seguida, articular os dados assim construídos. Também apresentamos nesta seção trechos das entrevistas individuais semiestruturadas realizadas com o Coordenador e com a instrutora da disciplina Polícia Comunitária do CFO, de onde emergiram importantes indicadores relativos aos conceitos, crenças, valores e posicionamentos em relação às questões de violência e de paz.

Vale salientar que durante o trabalho, a pesquisadora realizou observações diretas das principais atividades práticas rotineiras do CFO, tais como desfile militar diário, participação em solenidades oficiais, atividades esportivas, jornada de campo e palestras. As principais informações foram anotadas em um diário de campo, que foi utilizado como auxílio na análise dos dados das entrevistas e dos grupos focais.

Para analisar as narrativas dos participantes, inicialmente, foi realizada a transcrição integral das entrevistas individuais semiestruturadas e das sessões dos grupos focais. Em seguida, realizamos uma análise geral, visando identificar indicadores e expressões (verbais ou não) que nos permitiram inferir aspectos relacionados com significados da carreira militar, valores militares, conceitos de violência e paz, mediação de conflitos e questões afins, constantes dos roteiros elaborados (anexos 1 e 2). A análise foi feita identificando marcadores recorrentes e significações específicas, indicadores dos posicionamentos dos participantes com base em suas narrativas. Cada uma das entrevistas foi revisada em sucessivas análises. A transcrição do grupo focal foi analisada, também, sucessivas vezes, a fim de identificar indicadores relacionados às temáticas propostas, buscando verificar a existência de consonância, ou não, entre os posicionamentos aí apresentados e aqueles observados nas entrevistas. O objetivo foi, assim, considerar todos os indicadores obtidos, por meio das entrevistas individuais e do grupo focal, no sentido de ampliar nossa compreensão sobre os posicionamentos dos participantes, tendo em vista os objetivos da pesquisa.

As entrevistas com todos os participantes foram realizadas no início do ano de 2015. A princípio, destacamos a confiança e a espontaneidade com que os cadetes aceitaram participar da pesquisa. Tinham pouco tempo na instituição (três meses), e se esforçavam para se adaptar a um ambiente completamente novo e estranho. Observouse, entre os cadetes, certa apropriação da linguagem e a utilização de palavras típicas da 
cultura militar, o que bem demonstra o seu empenho em internalizar aspectos específicos da instituição, considerando que os participantes eram oriundos do mundo civil. Por exemplo: "embuste", "o civil não é minucioso igual a gente é", "dar uma pressão nele", "vibração da tropa...". Também chama atenção uma dicotomia entre a naturalização da violência e a indignação com sua prática, algo muito destacado pelos cadetes. As discussões do grupo focal nos possibilitaram observar uma grande sinergia entre o que eles gostam na formação e o que acham inadequado ou desnecessário. Ao mesmo tempo, surgiram questões peculiares, como a questão de gênero e uma posição crítica a respeito do desenvolvimento institucional.

O grupo dos tenentes demonstrou grande familiaridade com a "cultura militar" (Moreira, 2011), em termos de linguagem, jargões militares, postura corporal, maneira de se expressar etc. No momento da entrevista, estavam formados havia dois anos, ou seja, dois anos de prática policial militar nas ruas. As falas desses participantes remetem muito ao sentimento de indignação e revolta com a violência, sobretudo contra os policiais militares. Expressam de forma significativa seu sentimento de pertença ao grupo (PM) e descontentamento com o desrespeito sofrido por parte dos militares em situações diversas. O grupo focal provocou uma intensa discussão sobre o primeiro dilema moral acerca da "culpa" pela violência vivida pelo personagem, e trouxe posicionamentos muito diversificados sobre a formação e sobre a prática policial. Destacou-se a dificuldade em agendar a sessão de grupo focal, uma vez que os tenentes trabalhavam em locais diferentes com escalas distintas. No dia marcado, um dos participantes teve um imprevisto e desmarcou, e outro chegou ao final da sessão, pois estava envolvido em uma ocorrência policial, da qual não poderia se ausentar.

Apresentamos a seguir a análise construtivo-interpretativa das narrativas apresentadas pelos participantes. A ordem de apresentação dos resultados é a seguinte: (4.1) Entrevistas individuais com os cadetes; (4.2) Grupo Focal-Cadetes; (4.3) Entrevistas individuais com os tenentes; (4.4) Grupo Focal-Tenentes; (4.5) Entrevista individual com o Coordenador; (4.6) Entrevista individual com a instrutora da disciplina Polícia Comunitária.

Tendo em vista a extensão dos dados, selecionamos para apresentação apenas os trechos considerados significativos ou relevantes face aos objetivos da pesquisa. Os turnos de fala da pesquisadora estão identificados com a letra $P$, e dos entrevistados com a inicial de seus nomes. Como já dito anteriormente, todos os nomes dos participantes da pesquisa são fictícios. 


\section{1 - ENTREVISTAS INDIVIDUAIS COM OS CADETES}

\subsubsection{Análise Entrevista Cadete Moisés}

\section{1 - Significado da carreira de Oficial da PM}

Trecho 1 (linhas 5 a 9)

“(...) PESQUISADORA: Em primeiro lugar, gostaria de saber, o que te motivou a ingressar na carreira de Oficial da Polícia Militar?

MOISÉS: Eu nunca pensava em ser oficial da PM, acho que não é a carreira dos sonhos de muita gente né? Não de muita gente que ta na faculdade de direito né? Ninguém entra lá e fala 'Ah, eu quero ser PM'. Eu queria ser Delegado, a princípio (...)"

\section{(linhas 33 a 34)}

“(...) M: Por que ainda tem muito preconceito com isso. Quando fala em PM a gente logo... Lembra logo de Tropa de Elite né? Tapa na cara, pede pra sair, coisas desse tipo (...)" (linhas 47 a 48)

“(...) M: Não adianta ser hipócrita né? A primeira coisa que chama atenção é o salário. Não é as mil maravilhas, mas já é um salário muito bom (...)"

(linhas 71 a 73)

“(...) M: E depois a gente vai conhecendo as funções, que... são... Muito interessantes também. É um poder, que de certa forma... Que seduz né? Uma pessoa fala, 'Ah, vou presidir um IPM, vou é... instaurar sindicância, vou poder participar de conselho depois...' É... Então, é uma carreira bem legal! (...)"

\section{Análise 1}

Moisés busca na carreira de Oficial da PM uma estabilidade salarial e um status, que, a princípio, foram desejados através do cargo de Delegado da Polícia Civil. Por não conhecer a carreira, era movido pelo imaginário popular de que todos que fazem curso de formação na PM serão submetidos às etapas massacrantes mostradas no filme "Tropa de Elite". Concomitantemente, ele postula uma frase muito expressiva: "É um poder, que de certa forma... Que seduz né?", demonstrando que, para além das obrigações, sente-se seduzido pelo poder que a carreira o concederá. Então o poder e autoridade que revestem a carreira, também foram um grande atrativo.

\section{2 - Avaliação da PM}

\section{Trecho 1 (linhas 111 a 118)}

"P: Hoje, você gosta de fazer parte da Polícia Militar? Explique...

M: Gosto bastante! Sinceramente... Porque é uma instituição... De certa forma você tem uma 
função legal, uma função dentro daquilo que você estudou e que o pessoal é muito unido, pelo menos os que a gente teve contato até agora, a união aqui dentro é muito forte... Então a gente chega aqui e vê todo mundo querendo se ajudar, ajudar a instituição é bom, é gratificante. A gente fica feliz de fazer parte de uma instituição assim.

$\mathrm{P}$ : O que você considera como seu ponto forte? Aquilo que você traz para contribuir com a PM?

(linhas 141 a 143)

M: O meu ponto forte é o ponto forte da maioria aqui, que é querer mudar. E a gente espera fazer essa mudança em uns 5 anos! E a imagem dela né? Além de mudar ela, mudar a imagem que ela tem. Que a imagem da PM não é boa, infelizmente"

(linhas 169 a 175)

"Quando as pessoas perguntam como é aqui, a gente fala que a gente treina que estão invadindo a APM; que a gente protege aqui de noite... Que é muito bom, mas essa parte chata (treinamentos exaustivos, faxina, etc.) não! É... É... É até pra mudar a imagem da instituição, as coisas que o pessoal fala, 'Nossa mas vocês passam por essas coisas lá mesmo?' Eu falo 'não, não passo. Isso não tem mais, isso era coisa da polícia antiga... Polícia hoje é nova...' Até tentando dar uma nova cara né? Pra instituição. Porque realmente tem um preconceito forte, acho que a maioria por essa questão da ditadura. Que alias foi um período que eu nem vivi né? Mas pelo que a gente ouviu falar, acho que associou e ficou assim".

\section{Análise 2}

Moisés afirma o forte preconceito existente contra a instituição e fala sobre seu desejo em contribuir para mudanças da instituição, inclusive dizendo que este é o seu ponto forte (para contribuir para a mesma). Enxerga a união como um valor. Não é explícito ainda seu sentimento de pertença, mas já revela uma satisfação em fazer parte de uma instituição que cultiva a união. Outro aspecto observado é o esforço para mudar a imagem que a PM tem lá fora, inclusive mentindo sobre os treinamentos exaustivos que vê como desnecessárias

\section{3 - Violência: Conceito e Valor}

\section{Trecho 1 (linhas 222 a 231)}

"P: Já que você está falando de práticas, sobre as práticas cotidianas da Polícia Militar, você diria que envolvem violência?

M: envolve sim, infelizmente. Mas... A culpa não é da PM, é da administração como um todo. Então a falta de interesse da administração publica, é... Gerou um aumento na criminalidade muito grande aqui no estado, que não é tão divulgado, mas infelizmente existe. Então, como essa questão da violência tá tão grande, por uma série de fatores, que não são culpa da 
Polícia, não são problemas de Polícia, são problemas de administração... Por a violência tá tão grande, realmente a Polícia age com violência... E isso não é escondido nem dos alunos, no curso de formação... 'Oh, realmente é assim aqui na Polícia...' Infelizmente a Polícia é violenta"

\section{Trecho 2 (linhas 235 a 242)}

"M: Mas é até por necessidade e por vontade de ajudar, porque é uma coisa muito interessante aqui na Polícia, é que realmente eles têm muita vontade, principalmente quem é militar. Eles realmente têm muita vontade de proteger o cidadão. Então, a forma que eles passam pra gente do ladrão "ah, o ladrão, o ladrão, o ladrão tem que ser preso..." Realmente a gente fica... "Ah, o ladrão, eu tenho que odiar, é meu inimigo! Tenho que odiar o ladrão". Eles usam ladrão no termo genérico, é pra bandido... Então, infelizmente, a Polícia age com um pouco de violência sim, por necessidade e infelizmente não... Não... Não resolveu, até hoje, e não vai resolver o problema da segurança publica, que infelizmente só cresce a cada ano né?"

\section{Trecho 3 (linhas 243 a 248)}

"P: Em que casos você acha que essa ação se justifica? A ação violenta da PM se justifica?

M: Que só se justifica quando realmente colocar a vida de um policial em perigo ou colocar a vida da sociedade... E isso não é hipocrisia, não é hipocrisia nenhuma, eu to falando a verdade! (ênfase) É... Se um cara ta armado ou se ele vai agredir um policial, ou vai agredir um cidadão, só nesses casos que pode usar a violência, com certeza"

\section{Trecho 4 (linhas 339 a 357)}

"PESQUISADORA: O que você considera como violência? Se você tivesse que definir pra alguém...

M: Violência? É... Violência... Éééééé... É o uso da força além do necessário! Isso é violência!

$P$ : Como você percebe isso?

M: O trabalho Policial, ele é um trabalho agressivo! Não tem é... Tem a parte da Polícia comunitária e tudo o mais, mas em regra, o Policial tem que ser uma pessoa mais agressiva! Mas ele tem que ser agressivo sem ser violento!

$P$ : E como seria isso?

M: Saber até onde ele pode usar a força. Porque o estado...

$P$ : Existe uma dose?

M: Existe, claro! E como diz o coronel A., o coronel A. falou uma coisa interessante: que o estado, ele tem o monopólio da violência! Isso com certeza algum pensador falou, não é dele né? Algum... E já é antigo isso, não sei se é do... (pequena pausa) Ah, algum... Algum pensador falou isso aí. Até li uma vez, li e pensei, "Ah, olha aqui da onde o coronel Anésio 
tira aqui o discurso" Mas o... O Estado, ele tem o monopólio da violência, quem que exerce essa violência? Quando ela é necessária né? 90\% das vezes é a Polícia Militar! Mas o... É diferente! (pequena pausa) A violência, ela é o... (pausa média) Ela é necessária, igual eu já falei, mas ela, ela não pode ter excesso! E algumas vezes há o excesso!"

Trecho 5 (linhas 363 a 365)

"P: De uma forma geral, você acha a violência é necessária?

M: É... Se alguém entra na sua casa, por exemplo... Você tem que se defender, é uma violência legítima né? (longa pausa) Ela é necessária apenas como defesa!"

Trecho 6 (linhas 374 a 387)

"P: Nós sabemos que é melhor prevenir do que reprimir, mas será que é possível prevenir todo tipo de violência?

M: Não.

P: Por quê? Me explica...

M: O homem ele é... Prevenir todo tipo de violência? Tá! Essa questão de... Má gestão pública, esse discurso que todo mundo sabe né? Gera criminalidade, gera violência... tá! Mas o homem, eu acho que ele precisa de violência é... É um paradoxo né? É tão contra,

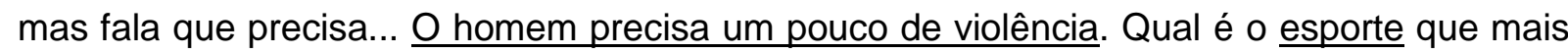
faz sucesso hoje no mundo? Não é o futebol mais... É UFC, MMA, K1, Pride, é luta! E... Eu confesso, eu particularmente prefiro assistir uma luta do que um jogo de futebol! Então o homem gosta de violência, não é? (pausa pequena) Se não houvesse a violência, ia ser muito certinho as coisas né? la ser muito... Tem que... Tem que haver... Eu acho que $\underline{0}$ mundo precisa de violência...

$\mathrm{P}$ : Você acha que a violência é inerente à natureza humana?

M: É sim, inerente à natureza humana!"

\section{Análise 3}

Para Moisés, a violência faz parte integrante da natureza humana. Dá a entender que sem ela a vida seria um pouco sem graça e, como exemplo, lembra como que os esportes violentos são os mais populares e interessantes. Diz que "la ser muito... Tem que... Tem que haver... Eu acho que o mundo precisa de violência..."

Em seguida, porém, ele entra em contradição, da qual não se dá conta, quando afirma que o trabalho da PM "envolve sim (violência), infelizmente. Mas... A culpa não é da PM...". Aqui, sente necessidade de desculpar a PM pela violência que a caracteriza.

A definição de violência apresentada por Moisés, demonstra uma resposta pronta e ensinada na disciplina: o tema é o 'Uso progressivo da força”. Porém, sua reflexão posterior amplia essa definição, demonstrando que, em sua opinião, a PM faz uso de ações violentas, não 
iniciativa ou por vontade própria, mas sim em resposta a um ataque, quando busca defender um colega ou a sociedade. Fica evidente que essa ideia é disseminada na formação, mas ele acha essas ações violentas não resolvem o problema da Segurança Pública, pois a culpa do crime e da violência está na administração pública mal gerida. No último trecho, vemos novamente um conceito muito bem formatado (estruturado tipo resposta padrão) de que a violência policial só é justificada em caso de legítima defesa. Vemos aqui um misto do que ele tem como conceito pessoal de violência, fortemente influenciado pelo que ele está aprendendo ou visualizando em sua formação.

\section{4 - Paz: Conceito e Valor}

\section{Trecho 1 (linhas 422 a 439)}

"P: Atualmente, fala-se muito na questão da paz. Como você definiria paz?

M: Paz é a ausência de guerra né? Simples, ausência de... De confronto!

$\mathrm{P}$ : Confronto direto?

M: Sim, é um conceito por exclusão... É ausência de confronto direto... não só direto, não só confronto físico né? Disputa de poder, ou alguma coisa assim que ás vezes a pessoa pode viver com medo, ele não tá em paz né? Vive com medo, apesar da pessoa nunca ter visto nada iminente, quem vive com medo não vive em paz né? Então, acho que é o conceito de paz... acho que é esse, é muito simples né? Acho que é esse, por exclusão. Paz é ausência de conflito!

\section{P: Então Brasil é um país que vive em paz?}

M: $\underline{O}$ Brasil vive em paz, a maioria da população não! O Brasil vive em paz... Por que quando a senhora fala de "o Brasil vive em paz", a senhora tá falando do Estado. O Estado tá em paz, ele não tá em confronto com nenhum outro Estado! Até onde a gente saiba, não.

\section{Trecho 2 (linhas 463 a 483)}

"P: E a Polícia Militar? Você acha que ela promove a construção da paz?"

M: Ela tenta! A maioria tenta!

$P$ : Como... De que forma ela tenta?

M: Ah... Pensamento que se tem de PM hoje, por incrível que pareça, de uns 10 anos pra cá, graças a Deus, é mais voltado pro cidadão de bem do que pro bandido né? Até uns 10 anos atrás, o policial ia lá e prendia o bandido! A PM hoje tanta aproximar mais de quem não é bandido! Ela viu que a função dela não é só prender o bandido, é TAMBÉM prender o bandido né? Mas é tá em contato com a população de bem... Dentro da escola né? Tem o PROERD que é bem legal... A PM serve pra manter... dá até uma certa paz, nem que seja psicológica pra pessoa que ainda não foi vítima né? E que, se Deus quiser, não será...

$\mathrm{P}$ : O que seria uma paz psicológica? 
M: A paz psicológica éééé... Vou definir com mesmo conceito: é a ausência do medo! A pessoa quando ela tem medo, ela não tá em paz! O que tira a paz psicológica é o medo! 'Ah, será que o meu próximo comandante aqui do CFO vai ser ruim? Será que vai ser fulano? Será que o tal do coronel fulano vai voltar aqui pra APM?' Isso é medo né? Quem tá com esse medo não ta com paz psicológica! Paz psicológica, então, seria a ausência de medo, viver sem medo.

P: Então nesse sentido, você acha que a PM contribui pra construir essa... essa Cultura de Paz?

M: Contribui! Mas acho que poderia contribuir mais, se tivesse um pensamento mais voltado pra isso... mais programas, mais empenho".

\section{Análise 4}

Aqui vemos um conceito simplista de paz: ausência de guerra, de confronto. Como o próprio participante revela, um conceito por exclusão, com respostas bem padronizadas do senso comum, como verificado em pesquisa anterior (Moreira, 2011). Percebe-se que o tema não deve ter sido tratado em sua formação anterior (Bacharel em Direito), nem deve ter sido abordado até o momento no contexto do CFO: seu conceito não é elaborado, nem indica reflexão sobre o assunto. O participante não elabora a grande contradição gerada com a pergunta da pesquisadora sobre estar ou não o Brasil em paz. Quando afirma que "O Brasil vive em paz, a maioria da população, não!". É como se sua noção de Estado-Nação não incluísse a população. Mas isto não é percebido por ele. Segundo ele, o Estado em paz e as pessoas em paz, são coisas totalmente distintas. O Estado não tendo confronto declarado vive em paz, mas as pessoas não, devido ao medo. Tal pensamento é mais explorado no trecho 2, onde ele reflete sobre o papel da PM na construção da paz e traz o conceito de 'paz psicológica', percebida como ausência de medo. Este medo não teria uma base material, seria para ele "psicológico", e em relação a isto a PM pode ajudar a pessoa "... que ainda não foi vítima né? E que, se Deus quiser, não será..." Ou seja, a prevenção do crime, enquanto evento material, está nas mãos de Deus! O papel da PM de garantir a paz social é pouco elaborado na fala dele, mas ele se refere a uma evolução da própria instituição no sentido de estar mais próxima do cidadão de bem (fala da Polícia Comunitária e do Proerd). Mas não elabora por qual razão isto é importante para a prevenção da violência e para a construção da paz...

\section{5 - Formação do Oficial na PM}

Trecho 1 (linhas 531 a 545)

"P: O que você acha da formação do Oficial na Polícia Militar? 
M: É... Eu entrei pensando 'Ah, deve ser uma função de comando, um negócio bem legal!' Inicialmente foi uma decepçãozinha! É... Esse negócio de ficar alojado, de ficar marchando no sol... Que as duas primeiras semanas é só isso né? Marchando no sol, no alojamento a gente dorme muito mal, quando deixava a gente dormir né? Aí... Esse negócio é muito chato, mas deve, deve melhorar... É... Então... (pequena pausa) Aí eu falei, não, mas isso deve ser diferente. Aí um dia eu precisei da Polícia... Aí eu fui no Oficial de Dia, ele é um pouco xarope, mas eu fui falar com ele. Aí ele falou pra mim 'não... que que é isso... Pega uma viatura, cautela uma pistola, vocês já tão habilitados em revólver, já tão sabendo mexer e tal... cautela um armamento, chama uma viatura, chama um aluno Simve, vai e ajuda ela'. Eu falei 'Nossa!!!' O tratamento desse oficial com a gente, durante o expediente é totalmente outro. Eu achei até que ele ia falar 'se vira cadete, fala pra ela chamar o seguro'. Aí com essa atitude eu comecei a olhar que eles são muito unidos, em situação que a gente precisa deles, eles fazem até muito mais do que... Do que poderiam fazer, não é nem do que eu esperava, é do que poderia né?"

\section{Trecho 2 (577 a 583)}

"P: E como você acha que a PM orienta seus policiais?

M: A Orientação é boa, mas tem instrutores e instrutores né? Tem instrutores que o cara comanda pelo exemplo. Dá... Dá prazer em ouvir! Mas tem outros instrutores que... Que tem uma visão diferente né? Então, a formação depende... aqui depende do comando! Aqui dentro tem muita coisa boa e muita coisa ruim, tem que dar um pouco de sorte, tem que tá na companhia certa! E a PM por ser uma instituição muito grande, tem um efetivo de 13 mil homens hoje... Não da pra falar que é a PM em geral, existem várias Polícias né?"

\section{Trecho 3 (linhas 607 a 614)}

"P: Existem diferenças na formação, então?

M: Claro! Ah, e tem uma coisa muito interessante, talvez possa até ser útil na sua pesquisa, uma coisa que eu observei de uns 15 dias pra cá: as companhias que são as que sofrem mais, que tem uns treinamentos malucos, sem finalidade, elas são as menos disciplinadas, por incrível que pareça, são as menos disciplinadas, as que tem mais dificuldade de... De... De compreender alguma coisa quando a gente tá a frente. Entretanto, as companhias que tem os comandantes mais humanos, mais... É... que conversam mais, não colocam essas coisas absurdas, elas são as que fazem as coisas perfeitas aqui!"

\section{Trecho 4 (linhas 635 a 639)}

"M: A vontade nossa de mudar essa Polícia é muito grande! Até o comportamento nosso com os alunos soldados, os alunos Simve é totalmente diferente do comportamento que eu ouvia falar que os cadetes tinham aqui dentro né? Então eu acho que isso até desagrada o comando da academia... É uma postura nossa, eu acho que não vai mudar, nossa cabeça é 
muito diferente"

\section{Trecho 5 (linhas 670 a 685)}

"P: Em que situação no Curso de Formação de Oficiais, questões como essa que nós estamos conversando sobre violência, foram discutidos com a sua turma?

M: Sim, especialmente na disciplina de Polícia Comunitária e Abordagem.

P: E aqui no CFO, você acha que o curso de formação, ele promove a Cultura de Paz?

M: Entre os cadetes sim! Tem a questão da competição... tem a questão da competição, mas a competição é muito saudável, é a piada nossa! 'Ah, fulano é o número um, ah, fulano tá estudando demais, ah fulano tirou uma nota boa, tá querendo ser promovido primeiro que eu?'. É uma forma de curtição... É... Entre nós e os outros, e nossos subordinados promove também... O primeiro comandante nosso, no primeiro dia, falou : 'Então, essa aqui é a hierarquia, vocês estão aqui óh! Vocês estão acima de $90 \%$ da PM. Então, com seus subordinados tem duas regras: primeiro, nunca fale alto com seu subordinado. Segunda, nunca encoste a mão nele! Independente do que ele te falou, do que ele fez com você, você tem meios legais, você pode comunicar, fazer algo com sua assinatura aí que vai enrolar pra ele. Então entre nós e entre os praças... Promove a paz sim! E... E entre nós e a sociedade? Promove também! A grande maioria dos instrutores falam sempre disso para gente..."

\section{Análise 5}

O trecho 1 mostra alguém que estava vivenciando um processo de decepção com a forma dura do treinamento a instituição, mas que procura compensar isto com a percepção de camaradagem e união que vivenciou com um superior quando precisou de ajuda. Chama atenção a fala: "Aí com essa atitude eu comecei a olhar que eles são muito unidos..." O uso do pronome "eles" deixa evidente que o sentimento de pertença à PM ainda não foi construído, fazendo uma clara separação entre eles (PM) e nós (cadetes). O que é bem compreensível pelo pouco tempo na instituição (3 meses). Nos trechos 2 e 3, Moisés faz algumas reflexões sobre a formação. No seu relato, destaca que há diferentes formações dentro da mesma instituição, dependendo de quem coordena e de quem instrui. É uma observação interessante, uma vez que todas as formações da PM têm a mesma Matriz Curricular Nacional e deveriam seguir usar de estratégias semelhantes para atingir os mesmos objetivos. No entanto, o que ele afirma condiz com todos os estudos sobre currículo oculto nas escolas, onde valores e crenças são transmitidos sem estarem explícitos nas grades curriculares, e cada professor acaba ensinando do seu jeito e com resultados muito diferentes. $O$ trecho 4 demonstra uma pessoa que tem um forte desejo de contribuir para a mudança de sua instituição, e destaca posturas próprias de sua turma mesmo se isto desagradar ("eu acho que isso até desagrada o comando da academia"). Quando 
perguntado sobre a cultura da paz, Ihe ocorre que esta é promovida entre eles, os cadetes: mesmo que haja competição, eles procuram minimizá-la sob a forma de brincadeiras. Lembra também que as duas regras de comportamento em relação aos subordinados (nunca gritar com eles e nunca os tocar fisicamente) é fundamental para manter a paz entre eles.

\section{6 - Conflito e suas funções}

Trecho 1 (linhas 710 a 727)

"P: Eu gostaria de saber, agora, o que você considera como conflito?

M: Conflito? Conflito é uma divergência de interesses né?

Lá no Direito eles explicam assim pra gente... 'Ó, a partir do momento que o homem decidiu viver em sociedade, surgiu o conflito!' Mas... Não é nem divergentes, eu falei divergência né? $\mathrm{Na}$ verdade são interesses convergentes que geram o conflito. Onde tiver ser humano vai ter conflito... Não só ser humano não, animal também tem conflito, eles vivem em conflito. A natureza é um conflito!

$P$ : Você acha que o conflito pode ser construtivo?

M: (pausa longa) Sim... A gente tem conflitos com as pessoas, né? Mas a gente não tem conflito só com quem a gente não gosta, a gente tem conflito com quem a gente mais ama! A gente tem conflito em casa, tem conflito com namorada, e é coisa que... Engraçado que às vezes, depois, fica algo até melhor... O conflito resolveu uma situação, uma discussão ou algo assim... traz novas ideias. A gente aprende muito com o conflito.

P: Você poderia me dar um exemplo de conflito construtivo?

M: (pequena pausa) Aqui no CFO mesmo, a disputa pelas vagas, pelas primeiras colocações. Isso é positivo, a gente faz piada com isso todo dia, já chega no alojamento em vez de falar bom dia, fala 'ah, quanto você tirou em estatística?' e faz a gente estudar mais na próxima prova...

\section{Análise 6}

Nesse trecho vemos a clássica definição de conflito que depois é corrigida: de divergência de interesses passa a convergência de interesses. Nesse momento Moisés se confunde e não percebe que desejar alcançar um mesmo objetivo significa objetivos divergentes, pois cada qual deseja alcançar o sucesso para si e não para o outro, o que constitui uma divergência! Conflitos existem em situação de competição, explícita ou implícita, seja em termos de conquistas materiais ou simbólicas, como bens materiais, posição, status ou poder.

Quando Moisés faz uma pausa demorada para responder à pergunta da pesquisadora sobre se existem conflitos construtivos, pode-se perceber que muito provavelmente nunca havia pensado sobre o assunto, também fazendo uma pausa para pensar quando perguntado 
sobre um exemplo concreto. A maneira como ele elabora a resposta indica que Moisés está no momento refletindo sobre o tema, ou seja, a ideia de conflitos poderem ser positivos parece nunca haver lhe ocorrido antes.

\section{7 - Análise das imagens}

Trecho 1 (linhas 787 a 789)

"P: Vou te mostrar agora 4 imagens, quero pedir pra você me falar como se sente a respeito (a pesquisadora mostra 1 de cada vez)

Imagem 1 - Civil chutando o rosto de um policial militar (linhas 799 a 803)

M: A imagem ficou forte porque foi feita exatamente no momento que o rapaz chuta o rosto do policial né? Mas esse confronto é muito antigo e, aliás é... Como é que eu vou dizer? Eu não gostaria que acontecesse, mas infelizmente acontece e vai continuar acontecendo. Parte da torcida vão lá pra brigar mesmo, parte da PM vai lá pra bater mesmo... Então infelizmente essa questão de confronto de PM com torcida acontece, vai continuar acontecendo e só a PM que segura, nos estádios...

Imagem 2 - Policiais militares agredindo um civil (linhas 830 a 835)

M: Polícia não pode agir assim... entrar num banheiro e espancar um cidadão. Esse pessoal do Simve não se espera... Não se espera coisa diferente não, ainda mais que eu vi... EU VI... (ênfase) como eles foram treinados aqui na academia. Eles já vem com aquela energia do Exército, aquela vibração... O curso deles é muito pequeno, eles não tem formação... se tiver alguma coisa na área de Direitos Humanos, alguma coisa assim é... Deve ser faz de conta. É problema de formação.

Imagem 3 - Coronel da PM agredido em uma manifestação (linhas 849 a 850)

M: Essa imagem a gente viu bastante né? Levaram a arma dele, do coronel. Acho um absurdo, mas é como eu falei em manifestação a gente tem que tá preparado pra isso né?

Imagem 4 - Policiais fazendo contenção de um civil em manifestação (linhas 882 a 885)

M: É só essa última que eu... Eu não tinha visto. Essa é dessas manifestações recentes agora né? O público não tá parecendo o público normal de manifestações... Tá mais pra uma reintegração, uma coisa assim... mas deve ser as manifestações mesmo, tem a imprensa em peso... Acho que é um procedimento normal da PM, abordagem de contenção normal.

\section{Análise 7}

Percebe-se a dificuldade do cadete em responder 'como se sente' a respeito das imagens. Sempre que perguntado, responde algo muito mais ligado ao raciocínio que ao sentimento. 
Apresenta um discurso muito conformista e resignado a respeito das cenas de violência apresentadas: "infelizmente acontece e vai continuar acontecendo". Seu discurso aqui é contraditório com sua ideia de mudanças. Será que ele acredita em possíveis mudanças nas relações entre a PM e as pessoas, a comunidade? Fica a dúvida. Ele também afirma que as ações violentas dos soldados é assim mesmo, pois estes "são assim mesmo", não tem "formação".

\section{8 - Análise do vídeo}

\section{Trecho 1 (linhas 915 a 927)}

"P: Como você se sente vendo esse vídeo?

M: Recuaria rápido, porque eles estão em menor número... De acordo com as imagens aí eles estão em menor número. Em manifestação nunca a polícia vai tá em maior número. Então eles tão ali, tão tensos, qual o primeiro agente do Estado que chega? O PM claro, em quem que cai a culpa de tudo sempre? Na PM! Chega o PM o primeiro que ele vai bater é no $\mathrm{PM}$, isso daí é certeza, é inevitável! Porque infelizmente a PM é o primeiro escudo do Estado, ela é o escudo do povo também, mas ela é primeiro escudo do Estado. Seja aqui, seja em qualquer lugar, país de primeiro mundo é do mesmo jeito! (...) Até nas outras policias, quando o bicho pega, quem poderá nos defender? Chapolin Colorado, a PM né? Então, são coisas que infelizmente quem entra pra profissão já entra até imaginando... 'Cachorro do governo...' Então esses apelidos... Isso aí a gente é treinado aqui pra ouvir lá fora! Isso a PM faz bem, a academia faz bem, ela nos prepara pra essa tensão lá fora! Que lá fora você não consegue ser maior que a multidão! Então pra mim, isso aí tá tranquilo..."

\section{Análise 8}

Ele tem dificuldade em relatar seu sentimento, suas emoções, a respeito do vídeo e tende a racionalizar, sugerindo que o que ocorre no vídeo é uma situação comum. Ele reverbera um discurso recorrente nos cursos de formação, onde é ensinado que a PM é o primeiro e o último recurso para todas as situações, e afirma que o curso os prepara para enfrentar situações deste tipo.

\section{9 - Sugestões e ideias para a Polícia Militar promover a Cultura de Paz}

\section{Trecho 1 (linhas 1036 a 1053)}

"P: Pra finalizar, eu gostaria de perguntar se você tem alguma outra ideia ou sugestão a respeito da construção de Cultura de Paz da PM. Lembre-se que as entrevistas não serão identificadas...

M: Tenho: só remover alguns... (risos) Algumas maçãs podres do cesto, que vai melhorar 
demais...

P: Você acha que algumas pessoas atrapalham o desenvolvimento dessa ação?

M: Sim, algumas pessoas nos locais errados! (pequena pausa) A pesquisa é sigilosa né?

P: Claro!

M: Que bom! Eu confio na senhora!

P: Agradeço a confiança

M: Do contrário eu terei sérios problemas! (risos) Mas infelizmente, se envolvem pessoas que... A senhora pode observar que muitas vezes não tem família, não tem... A vida deles é a Polícia, o que de certa forma é bom! Então, pega pessoas que são taradas (ênfase) na Polícia, a ponto de tá respondendo grandes problemas lá fora e coloca aqui dentro pra... Pra serem nossos modelos. E eles acabam passando algumas vezes informações que não se deve passar, tem que ter... Até no ensino tem que ter um pouco de... cuidado. Tem coisa que se fala e tem coisa que não se fala! Se a pessoa quiser fazer determinada coisa depois quando ele se formar, aí é por conta dele! (pequena pausa) Agora... aqui não se pode falar disso"

\section{Análise 9}

As observações feitas neste trecho são bem pertinentes e envolvem a construção subjetiva de um modelo de formador. O cadete sugere que, retirando alguns 'maus exemplos' da equipe de formação, esta seria bem melhor. É uma visão um pouco limitada, porém realista considerando o fato de que ele está há apenas 3 meses na instituição e o ambiente da PM que ele conhece até o momento é a APM. Sua inserção recente no contexto, entretanto, Ihe permite ver com maior clareza um problema que é gravíssimo, ou seja, atribuir funções de formação a pessoas de formação duvidosa ("tarados") e sem preparo emocional ou moral para exercer esta função. A situação deve ser séria, pois o participante pede sigilo total sobre esta informação e fala sobre o assunto com base na confiança que construiu com a pesquisadora. 


\subsubsection{Análise Entrevista Cadete Ester}

\section{1 - Significado da carreira de Oficial da PM}

Trecho 1 (linhas 6 a 15)

"P: Gostaria de saber, o que te motivou a entrar na carreira de Oficial da Polícia Militar?

ESTER: Sempre tive assim uma... Uma pré-disposição a policial porque eu sempre gostei muito de estudar direito penal... É... Eu já estagiei em juiz, vara de execução penal... Eu gostei um pouco dessa área e foi assim, saiu o concurso... Eu falo até que eu caí de paraquedas aqui, porque não tem ninguém da minha família, não tem nada e de repente eu tava no mundo policial que não conhecia nada! Mas assim, mais por uma questão de oportunidade, que eu queria um concurso público e que eu achava que eu tava... Eu gostava dessa área!"

\section{Análise 1}

A busca de uma justificativa para o ingresso na carreira de oficial parece um pouco contraditória. Ao mesmo tempo em que ela diz ter "uma pré-disposição" para área, afirma que "caiu de paraquedas". Já a dupla motivação entre o interesse pessoal pela carreira e a estabilidade que ela proporciona também apareceu na fala dos demais cadetes, o que nos leva a pensar que isto é algo comum nesse início de curso.

\section{2 - Avaliação da PM}

\section{Trecho 1 (linhas 23 a 32)}

"P: E hoje, você gosta de fazer parte da PM?

$\mathrm{E}$ : Mais ou menos! (risos)

P: Fique a vontade para falar, a entrevista é sigilosa!

E: Tenho medo de ficar frustrada! No sentido de... de ás vezes não... De não poder ser ouvida, de não ter assim... É mais questão assim, de ser desperdiçada! Sabe? De ter perdido tempo, de ter me dedicado e não... Não... Não conseguir ver os resultados que... Que eu penso, que eu quero, que eu desejo... eu me sinto como um... Um... O caminho já trilhado pela própria Policia Militar, entendeu? E não assim, a liberdade que eu poderia ter em outra profissão! Eu era advogada, então assim, eu tinha muita liberdade... E de repente eu fui... tolhida de tudo! Pra mim hoje é um sacrifício estar aqui!".

\section{Trecho 2 (linhas 54 a 60)}

"Eu não conheço esse mundo militar, eu não sei como que é após a academia! O que eu conheço é aqui de dentro. Não tem ninguém da minha família que é militar... Então por isso que eu acho que eu sinto tanto medo! Porque assim, eu to falando mais no sentido assim, sabe algumas coisas que você quer muito mudar, tem umas coisas que você acha que você 
não concorda e que não vai concordar nunca... E aí, ás vezes você fala 'não, na Policia Militar vai ser assim o resto da sua vida!'”

\section{Trecho 3 (linhas 66 a 72)}

"P: Mesmo com esse sentimento, o que você considera como seu ponto forte pra PM?

E: Assim, eu acho, que eu sou muito detalhista, que... e... persistente... Eu tento o tempo inteiro convencer a mim e a todos que estão do meu lado de que aquilo é o melhor... eu acredito que eu sou... que eu tenho um pensamento um pouco mais moderno".

\section{(...) (linhas 80 a 83)}

"E a vontade de mudar! Eu tenho vontade de mudar esses detalhes, essas coisas... essas coisas que eu não... Que me incomodam aqui e eu tenho certeza que... Esse excesso de ordens, essa boçalidade, desrespeito".

\section{(...) (linhas 86 a 88)}

"Aqui a pessoa não é ouvida, não pode expressar o que pensa. Então assim, eu tenho certeza que tem muita gente que pensa assim também! Eu venho com pensamento civil. Eu sou uma pessoa que estudou muito direito constitucional lá fora... Aí você entra aqui dentro e fica um pouco assustado! 'Pera aí, que mundo é esse?"

\section{Análise 2}

Esses trechos nos mostram uma pessoa com alto nível de revolta e indignação pelas regras e normas da instituição: "eu tinha muita liberdade... E de repente eu fui... tolhida de tudo! Pra mim hoje é um sacrifício estar aquil". Essa é uma fala muito expressiva e nela também há uma grande dúvida entre continuar o curso ou sair. De todos os participantes, essa cadete chamou a atenção pelo sofrimento expresso em termos verbais e não verbais por estar no CFO. A rigidez da disciplina e hierarquia militar foram mencionados por todos como ponto de incômodo ou discordância, porém para ela isto foi muito além, causando angústia ("Aí você entra aqui dentro e fica um pouco assustado! 'Pera aí, que mundo é esse?") e revolta "Esse excesso de ordens, essa boçalidade, desrespeito. (...) Aqui a pessoa não é ouvida, não pode expressar o que pensa”. A contradição experimentada entre a liberdade concedida aos cidadãos na Constituição Brasileira, sua vida civil e o ambiente militar gera dúvidas e "medo" de que não tenha feito a escolha certa para sua vida.

\section{3 - Violência: Conceito e Valor}

\section{Trecho 1 (linhas 180 a 185)}

"P: O que você entende por violência? Sua definição...

E: Violência? Acho que violência é quando... te agridem de alguma forma, seja ela física ou moral... Às vezes você... É... Sei lá, dependendo da forma que você encostar na pessoa 
pode ser visto ou não como violência... É muito relativo, violência! Às vezes se a pessoa tá ali, numa condição de... Uma condição mais vulnerável, vai... Qualquer coisa que você fizer, às vezes, pode ser uma violência. É muito relativo! Tanto pode ser física, como pode ser só moral!"

\section{(...) (linhas 191 a 194)}

"A partir do momento que você começou a pegar na pessoa com força, isso já é uma violência pra mim! Ou pode ser uma forma de violência, por exemplo, você querer humilhar a pessoa ali na frente de... De outras pessoas ou humilhar na forma de como você vai falar... Eu imagino que existem formas e formas de violência!"

\section{Trecho 2 (linhas 154 a 158)}

"P: Quando você acha que uma pessoa precisa utilizar a violência?

E: Violência assim, acho que poucas vezes você pode utilizar! Não me lembro agora de uma forma que você possa usar. Eu acredito mais no uso da força!

P: Me dá um exemplo...

E: No caso, pra você... Por exemplo, a pessoa ta te agredindo, pra você fazer... é... conter aquilo... precisa usar a força".

\section{Trecho 3 (linhas 238 a 244)}

"P: Temos visto algumas cenas da TV da sociedade amarrando e batendo em pessoas pegas em flagrante, especialmente de roubo e furto. Você acha que essa violência é justificável?

E: Justificável talvez sim, porque eu acho assim... É muita frustração da sociedade... Até da própria polícia, prender e não dar em nada! A própria polícia prende e às vezes não dá em nada! E aí talvez a sociedade pega, bate e talvez aquilo ali seria melhor do que a própria prisão... Pra própria sociedade, né? Acho que aquela surra que deu é melhor, porque não vai dá em nada mesmo o processo! Mas acredito que está errado! Também não vai resolver dessa forma"

\section{Trecho 4 (linhas 268 a 272)}

"P: Você acha que a Polícia Militar atua na prevenção da violência hoje?

E: Eu acredito que sim, porque apesar de existir instrutores e instrutores, a gente vê que existe pessoas com pensamento moderno, que pensam muito nessa prevenção da violência, alguns já vem com esse pensamento de polícia comunitária, de uma nova polícia, de uma mudança de paradigma... Eu sempre vejo isso aqui, eu escuto muito isso aqui... Então, por isso que eu acho... Eu acho que... é possível"

\section{Análise 3}

O conceito que ela traz para violência é ligado à agressão, física ou moral, envolvendo 
excesso de força ou desejo de humilhar a pessoa. Ela é capaz de perceber a relatividade e complexidade do termo violência, e como ele depende, por exemplo, da sensibilidade das pessoas. Os trechos 2 e 3 já expressam significativa incoerência. Enquanto primeiro ela diz a violência não se justifica, usando um argumento pré-convencional (Kolhberg) para justificar esta posição ("Por que existe um sistema que vai te julgar por isso!"), no trecho seguinte ela acha justificável a ação violenta da sociedade em agredir fisicamente um infrator da lei (linchamento) "talvez aquilo ali seria melhor do que a própria prisão... Pra própria sociedade, né? Acho que aquela surra que deu é melhor, porque não vai dá em nada mesmo o processo". Mesmo acrescentando ao final que a ação estaria errada, vê-se aqui uma tensão entre o que ela acredita ("melhor que a própria prisão") e o que é correto segundo a lei. Como alguém oriunda do judiciário, o discurso é marcado por esta tensão entre o que considera certo e errado (crenças pessoais versus normas legais).

\section{4 - Paz: Conceito e Valor}

\section{Trecho 1 (linhas 338 a 346)}

"P: Como você definiria paz?

E: Paz? (pausa longa) Eu acho que assim... Ummm... Um mínimo de... de... criminalidade, um mínimo de problemas sociais... né? Como por exemplo, esses tipos de problemas é... As manifestações que a gente tá tendo, que acaba quebrando essa ordem, é... A criminalidade muito excessiva acaba quebrando também essa ordem social que a gente tem, algumas coisas que... Alguns crimes muito, muito... Que tem uma expansão muito grande, que tem uma propagação muito grande né? $\underline{A}$ redução desses... dessa criminalidade, a redução dessas manifestações, a redução dessa indignação da sociedade, talvez seria considerada a paz! Não que zere, claro, porque isso não existe... Mas o mínimo possível, porque nada é $100 \%$ né?"

\section{Trecho 2 (linhas 349 a 355)}

"P: Você acha que no mundo de hoje seria possível construir a paz? Construir uma Cultura de Paz?

E: (pequena pausa) É bem difícil, falar do universo assim... (risos) É muito difícil, mas eu acho que sim! Sendo esperançosa, talvez sim né? Talvez sim, mas é difícil você conseguir colocar tudo mais ou menos num nível onde as coisas vão... Porque a gente vive em constante transformação, uma hora é um problema outra hora é outro... Quanto mais se reduzir a criminalidade, a indignação, a revolta... Esse tipo de coisa! Quanto mais se reduz, maior é a chance da gente viver em paz!"

\section{Trecho 3 (linhas 368 a 374)}

"P: Na sua opinião, tem uma parcela individual aí, nessa responsabilidade? 
E: Com certeza! (riso) Acho que a maior parcela é individual né? Não adianta eu querer mudar você, quem tem que mudar sou eu...

P: Então só pra eu entender, a paz, na sua opinião, está diretamente relacionada às práticas?

E: É só as práticas... Porque a própria ação da policia tem truculência, tem agressividade, e reforça isso lá fora... Acaba demonstrando pros outros que violência se resolve com violência. O que eu acho que tá errado"

\section{Trecho 4 (linhas 399 a 408)}

"P: Eu perguntei sobre... sobre a paz no mundo de hoje né? Você disse que acha difícil e tudo... E na Polícia Militar? Você acha que seria possível?

E: Claro, eu acho que é possível! Eu acho que é um bom lugar pra se iniciar...

$\mathrm{P}$ : Como você observa que a polícia promove a paz hoje?

E: A paz? Tentando resolver as coisas de forma inteligente! Fazendo planejamentos, programas, coisas que pouco se vê... né?

P: Tem algum programa da polícia que você acha inteligente, que promove a paz?

E: Tem, eu falei que a gente vê... Alguns comentários, da Polícia Comunitária... Tem algum... Ainda não sabemos como tá o PROERD, não tivemos instruções sobre ele ainda, mas parece que é um programa interessante também! Que age na origem mesmo... com as crianças... é o que eu conheço um pouco até agora".

\section{Análise 4}

Após hesitar (pausa), a cadete traz um conceito de paz social, associada à diminuição dos confrontos sociais: "Quanto mais se reduzir a criminalidade, a indignação, a revolta (...) maior é a chance da gente viver em paz!'. É interessante notar que ela se refere à diminuição das manifestações sociais, mas não às causas dessas manifestações (frustrações diversas, injustiças), o que sugere uma visão muito pouco crítica da sociedade. Concorda sobre as responsabilidades individuais na construção da paz e se refere, quando instigada, a PM como podendo contribuir para a construção da paz. Mas afirma que "a própria ação da policia tem truculência, tem agressividade, e reforça isso lá fora... Acaba demonstrando pros outros que violência se resolve com violência. O que eu acho que tá errado". Ao mesmo tempo, quando perguntada, diz que a PM poderia contribuir para a promoção da paz: "Tentando resolver as coisas de forma inteligente! Fazendo planejamentos, programas, coisas que pouco se vê...", e se refere a Policia Comunitária, sobre a qual ainda tem poucas informações. 


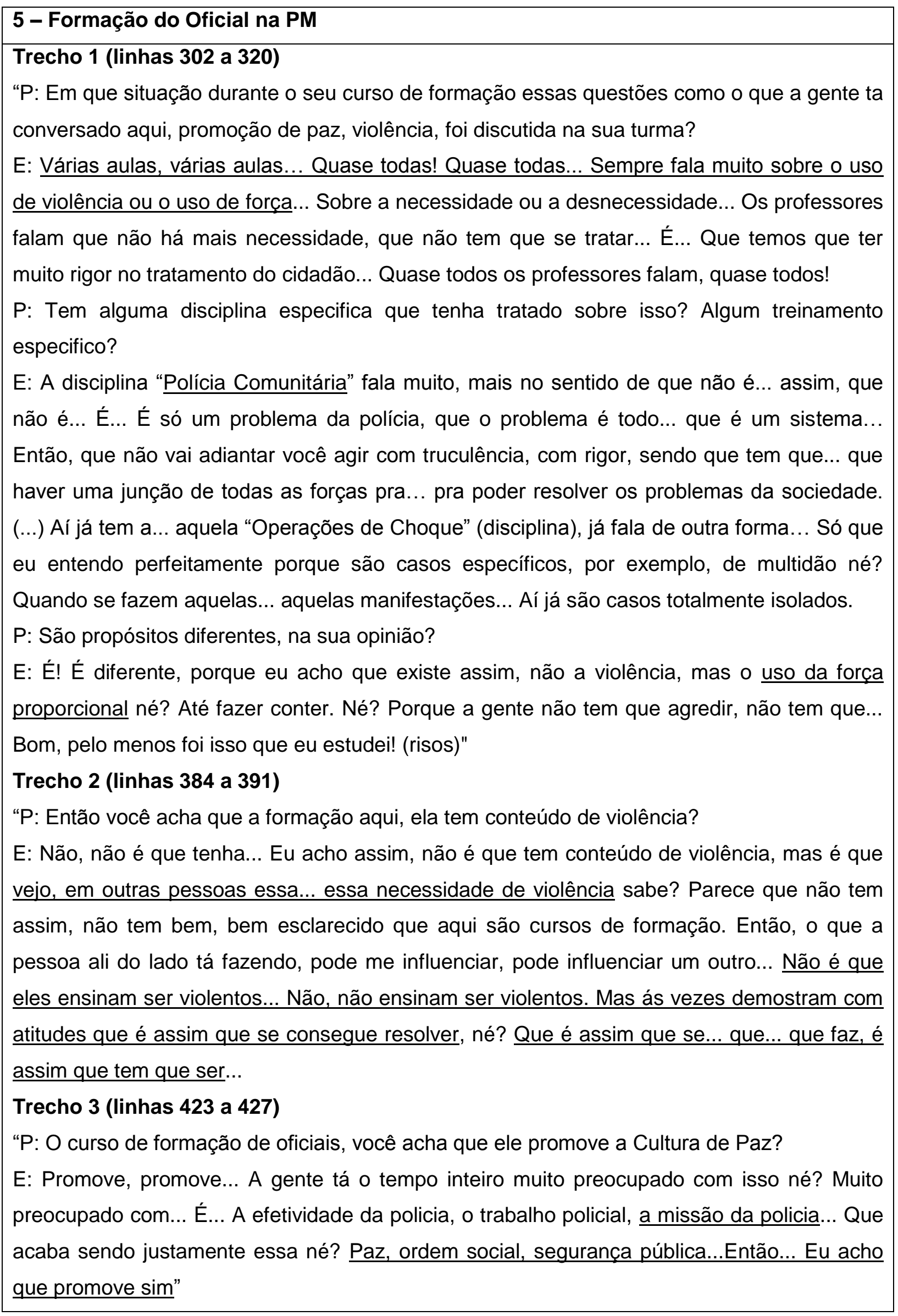




\section{Análise 5}

No trecho 1, Cadete Ester expressa que essa temática de violência e paz é amplamente discutida e trabalhada no CFO, de forma satisfatória, ao contrario de Moisés, por exemplo. Volta a falar sobre 'o uso da força proporcional', que é trabalhado na disciplina de Operações de Choque, que ela considera diferente porque fala de práticas que são empregadas em situações específicas. No trecho 2 quando ela é questionada se o CFO tem conteúdos de violência, ela interpreta a questão como 'se no CFO ensinam a violência'. Afirma que "Não é que eles ensinam ser violentos... Não, não ensinam ser violentos. Mas ás vezes demonstram com atitudes que é assim que se consegue resolver, né? Que é assim que se... que... que faz, é assim que tem que ser... Diz que existem algumas pessoas (instrutores) que tem atitudes violentas (práticas, falas, ações) e que isso acaba sendo percebido e servindo de exemplo para os alunos. Como o ambiente da APM é de aprendizagem, tais práticas acabam se tornando referência para alguns alunos, o que ela critica. No trecho 3 fica evidente que sua percepção a respeito do CFO é que este promove a Cultura de Paz, quando segue a missão da PM: 'paz, ordem social, segurança pública'. Reduz, assim, a Cultura da Paz ao senso comum e visão simplista de que, se a missão é esta, então o curso promove, sim. Dessa forma, na visão da cadete, o curso está cumprindo sua função de proporcionar uma formação pautada na Cultura de Paz e da não-violência, mas neste momento ela não faz qualquer ligação com o que disse antes sobre os exemplos de violência percebidos. Em outras palavras, não faz conexões ou articula melhor esta contradição.

\section{6 - Conflito e suas funções}

\section{Trecho 1 (linhas 460 a 478)}

"P: O que você entende como conflito?

$\mathrm{E}$ : Conflito são duas ideias diferentes, eu acho uma coisa você outra... E a gente não... não entra num consenso. $O$ fato de eu pensar de um jeito e você pensar de outro ali é quase que um conflito né?

P: Na sua opinião, o conflito pode ser positivo?

E: Pode!

P: Dá algum exemplo...

$E$ : Por que... Nesse exemplo mesmo, penso que... Eu penso $X$ e você pensa $Y$, talvez esse fato da gente entrar em conflito poderá... você me convencer de que eu estou... de que eu estou errada ou eu te convencer de que você está certa e talvez causar em você um bem, porque você tava se enganando com outra coisa... Então, pode ser positivo!

$P$ : Ele pode promover uma mudança?

E: Pode! De pensamento ou de atitude né? De ideias! Ás vezes no conflito é que surgem 
boas ideias né? Bons pensamentos...

P: A maioria dos conflitos você considera como positivos ou negativos?

E: Positivos! Porque os... traz mudanças né? Porque se fosse a vida inteira do mesmo jeito, aí que eu não ia aguentar ta aqui dentro mesmo! (risos) Eu acho que conflito é positivo...

$\mathrm{E}:$ De alguma forma tem uma perspectiva boa?

P: Com certeza! Porque pelo menos é igual ao que eu expliquei, acho que é um início de mudança! Tá mudando, tá começando a mudar!"

\section{Análise 6}

Ela reduz a definição de conflito ao mundo das ideias e pensamentos. Não se refere a conflitos físicos ou a eventos concretos de enfrentamento. Diz que se trata de "duas ideias diferentes". Talvez, aqui, uma leitura feminina do termo. Sendo assim, considera que o conflito seja algo positivo, pois promove mudanças 'Ás vezes no conflito é que surgem boas ideias'. Considera-o como algo transformador e expressa que se não fosse assim, se não houvesse mudança (refere-se a PM), ela não aguentaria permanecer na instituição. Como no início da entrevista ela falou sobre sua frustração na PM, pois tem a impressão de que nada vai mudar durante sua carreira, aqui ela expressa uma esperança de que conflitos possam provocar transformações de ideias e de atitudes. Interessante que essa reflexão surgiu no momento em que falamos de conflito, talvez porque tenham Ihe ocorrido os conflitos que ela está vivendo com a instituição.

\section{7 - Análise das imagens}

"P: Vou te mostrar agora quatro imagens e quero pedir pra você me falar como se sente a respeito."

Imagem 1 - Civil chutando o rosto de um policial militar (linhas 504 a 511)

"E: Éééé são pessoas que foram aí pra isso né? Pelo menos é o que dá a entender! Não é... não é uma... não é uma relação, é uma agressão mesmo!

E: A pessoa tá tendo a atitude de bater, de... humilhar o policial...

$\mathrm{P}$ : E como você se sente vendo essa imagem?

E: Eu fico preocupada! Por que igual... O dia que a gente foi no jogo mesmo, eu percebia isso, é um mundo muito... as pessoas são muito mal intencionadas. Elas vão pra aquele lugar com o intuito de fazer bagunça... Bater, arranjar confusão... E acabam usando o policial de... de... (pausa) Sei lá... usando ele pra mostrar isso de alguma forma!"

Imagem 2 - Policiais militares agredindo um civil (linhas 514 a 518)

"E: Acho que seria a falta de... de... A própria instrução mesmo que atrapalhou a formação dessas pessoas! Pelo pouco que a gente conhece, são pessoas que foram formados pelo 
exército, para a guerra né? E agora tentaram impor neles uma nova formação, para um outro tipo de policiamento. Então... A cabeça deles não conseguiu assimilar que a função agora era outra... Eu imagino né? Estou falando por fora sem saber, mas eu imagino que a formação não foi o suficiente."

Imagem 3 - Coronel da PM agredido em uma manifestação (linhas 527 a 535)

"E: Uai, é difícil falar sobre essa imagem! (pequena pausa). É... Infelizmente a gente corre esse risco né? Porque em manifestações acaba que as pessoas se escondem atrás umas das outras e manifesta sentimentos que ás vezes nem elas teriam se estivessem sozinhas né? Acabam agredindo pessoas que estão aí pelo contrário, sentido contrário, justamente pra defender. Na verdade a sociedade vê na polícia um... um pedaço do Estado né? E acabam se revoltando com a própria polícia, e tem nada a ver... Na verdade, a polícia tá pra outra função! Justamente o contrário. Sei lá... eu fico triste porque... não é essa a intenção da polícia militar. Eu acho que não é sociedade contra polícia... Talvez é sociedade contra governante, mas a própria sociedade não entende isso..."

Imagem 4 - Policiais fazendo contenção de um civil em manifestação (linhas 544 a 547) "E: Ohhhh... Agora eu to vendo a polícia fazer o serviço dela. Tirando uma pessoa que provavelmente seria um agressor... Com certeza ela deve ter feito algum tipo de agressão... Ela deve ter feito... É isso que eu to enxergando aqui, e a polícia tá fazendo seu serviço! Então a PM tá retirando ele da sociedade... Da manifestação pra poder... sei lá... Contê-lo!"

\section{Análise 7}

Ester fala de seu sentimento, de "preocupação", o qual, porém, não define muito bem. Parece se colocar no lugar do policial uma vez que ela já atuou nessa frente de serviço. Diante da imagem 2, semelhante à reflexão feita pelos outros dois cadetes, ela não fala de sentimentos mas considera que houve falhas na formação dos policiais, pois militares foram tradicionalmente preparados para a guerra e "agora tentaram impor neles uma nova formação, para um outro tipo de policiamento". Diante da imagem 3 demonstra um misto de tristeza e naturalização da violência sofrida pelo policial militar. Segundo ela, o contexto de manifestação vai acabar produzindo esses efeitos, mas é um grande erro a população se voltar contra a PM, como se ela fosse conivente com o motivo da manifestação. Diferentemente de Moisés que considera que a polícia representa primeiro o Estado e depois o povo (ver análise anterior), ela diz que ("Na verdade a sociedade vê na polícia um... um pedaço do Estado né? E acabam se revoltando com a própria polícia, e tem nada a ver... $\mathrm{Na}$ verdade, a polícia tá pra outra função! Justamente o contrário...)". Com relação à imagem 4, a cadete a considera uma ação normal da PM, de contenção, e não vê nenhum excesso ou expressão de violência, assim como seus colegas também se expressaram. 


\section{8 - Análise do vídeo}

\section{Trecho 1 (linhas 555 a 573)}

"P: Vou te mostrar agora um pequeno vídeo e quero pedir pra você me falar como se sente a respeito (mostrando vídeo).

E: Eu acho que falta informação da população, falta a própria Policia Militar mesmo informar e tentar diferenciar isso, mostrar que não é... A função da polícia é outra. Porque até hoje existe essa mentalidade que a polícia ta ali pra defender o governo, pensando da mesma forma... E não, ás vezes é uma pessoa que ta ali que se tivesse sem a farda poderia estar ali se manifestando. Também existe revolta na polícia, só que falta essa informação de que a polícia... De qual a principal função da polícia... Se ele ta ali, naquela manifestação, não é pra ir contra, não é pra poder bater de frente, é pra poder defender e... Fazer com que aquele direito de manifestação seja exercido. Eu fico revoltada porque parece falta de informação da própria sociedade. Não por que, por que ela quer, mas por que a própria polícia não ta preocupada em informar... Eu fico triste, contrariada... Porque parece que a visão que eles tem, e que todo mundo vai ter éééé... Que aqui ninguém vai me ver, vai ver só a farda, como um só... Então, eu fico contrariada das pessoas pensarem mal da polícia assim.

P: Como você acha que os policiais que estavam ali se sentiram?

E: Humilhados! Com certeza humilhados! Eu vi que tava um monte de gente atrás de uma mulher ali, só xingando 'cachorro do governo...' Com certeza humilhados, muito humilhados né? Porque ta todo mundo ali, o centro das atenções são aqueles policiais ali, como se eles tivessem agindo de forma errada, como se eles fossem os errados daquela situação".

\section{Análise 8}

Assim como nas imagens, aqui vemos uma expressão marcante de indignação e revolta, permeada pelos sentimentos de tristeza e humilhação. Mas para além desses sentimentos, vemos sua grande preocupação com a visão que a sociedade tem da $P M$, uma visão generalizada com a qual ela não concorda. De acordo com suas reflexões, a cadete não quer ser vista apenas como 'farda', mas como alguém por trás dela, que sente, sofre, se indigna, manifesta, enfim como um ser humano comum. Ao contrário do seu colega cadete Moisés, ela vê toda a situação do vídeo como um grande absurdo e falta de respeito não só com a PM instituição, mas com os policiais militares ali presentes enquanto pessoas. Ao mesmo tempo, não percebe que a presença da polícia tem toda uma história pregressa de violência e repressão àqueles que se manifestam nas ruas, o que ela desconsidera quando diz que "Eu fico revoltada porque parece falta de informação da própria sociedade". A questão é controversa, pois a sociedade sabe, sim, de suas experiências históricas, o que 
certamente não justifica o maltrato dos policiais como seres humanos que são. Enfim, ela generaliza sem considerar as razões mais profundas da revolta dos manifestantes.

\section{9 - Sugestões e ideias para a Polícia Militar promover a Cultura de Paz}

Trecho 1 (linhas 626 a 634)

"P: Para finalizar, lembrando especialmente o anonimato da pesquisa, o que mais você teria como exemplo, ou sugestão... Pra se trabalhar essas questões de paz e violência na PM?

E: Por que fica nesse... nesse engessamento. 'Ah... antigamente era assim, era assado...' tentando resolver do mesmo jeito... Então, eu acho que tinha que trazer, tinha que pensar mais e instruir nesse sentido de fazer mais estudos... Que seja os cadetes, botassem mais os cadetes pra estudar esses tipos de ocorrências que aconteceram em outros países né? De violência, como que se tratou, como que se agiu, e não ficar aí, batendo cabeça pra lá e pra cá. Do mesmo jeito que já era muito tempo atrás. Porque hoje nós estamos com problemas novos, mas que são problemas que os países já tão passando há anos e até já superaram alguns"

\section{(...) (linhas 659 a 672)}

"E: Também acho que deveria acrescentar algumas disciplinas e retirar outras né? Aproveitar algum tempo perdido aí de... No nosso... É, na nossa carga horária e... E acrescentar esse tipo de coisa! E até assim, colocar a gente mais na rua pra estágio, com pessoas mais instruídas que vão me acrescentar. A gente tem muita aula teórica... tinha que aproveitar melhor"

\section{Análise 9}

Finalizando a entrevista vemos ideias interessantes que envolvem mais estudos e pesquisas, que poderiam ser feitas pelos próprios cadetes, sobre exemplos de práticas exitosas na área de Segurança Pública até em outros países. Ela também faz uma crítica ao CFO, sugerindo acrescentar outras disciplinas, aproveitar melhor o tempo e, especialmente, sugere mais prática, e mais estágio supervisionado nas ruas. Esse também foi um aspecto pontuado pelo cadete Davi, sinal de que há certo descontentamento com a forma de distribuição da grade curricular do CFO. 


\subsubsection{Análise Entrevista Cadete Davi}

1 - Significado da carreira de Oficial da PM

Trecho 1 (linhas 5 a 11)

"P: Gostaria de saber, o que te motivou a entrar na carreira de Oficial da Polícia Militar?

DAVI: É... A princípio, eu sempre gostei da área policial. Sempre foquei meus estudos... nos concursos públicos que eu prestava na área policial. Meu objetivo era ser delegado de polícia... Não deu certo a aprovação e... A carreira de oficial me chamou atenção pela... pelo salário atrativo. E pela possibilidade de ascensão na carreira! E por estar no meu estado também!"

\section{Trecho 2 (linhas 18 a 25)}

"D: Eu sempre pensei em ser médico, quando eu era pequeno, mas era algo muito abstrato, era aquela coisa assim, ah, eu acho e legal e tal... Aí depois na... Fui descobrindo novas realidades e aí antes mesmo de pensar no curso de direito eu queria ser engenheiro ambiental... Aí fui fazendo o vestibular, passei, aí em dois mil e seis eu ganhei uma bolsa de direito, integral... Analisei a perspectiva de mercado, o meu perfil... Vi que encaixava bastante... Foi algo assim, escolhido um pouco em cima da hora, mas que deu certo!

P: E a faculdade, você gostou? Era o que você esperava?

D: Adorei! Adorei a faculdade, eu nasci pra isso! Curso de direito..."

\section{Trecho 3 (linhas 27 a 36)}

"P: E como é que surgiu o interesse de fazer concurso nessa área? Foi na faculdade ou depois de formado?

D: O interesse na área policial, propriamente dita, foi durante a faculdade... Da metade pro final! Que eu achei sempre interessante, essa questão de... um pouco... misto de adrenalina, um misto de estabilidade... profissional... Um misto também de status! Também, que faz parte. De prestigio e de... de... Realização de sonhos, pessoais e profissionais! Mas na realidade, eu nunca pensei em ser oficial da polícia. E também, pelo o que eu converso com meus colegas de turma, a grande maioria deles, e posso garantir pra senhora, que os sonhos deles, a priori não era ser oficial de polícia! Porque é uma carreira, que pelo menos pra mim, é uma carreira que... que... que poucos conhecem! Poucos conhecem! Não tem visibilidade, principalmente no mundo dos concurseiros!"

\section{Trecho 4 (linhas 56 a 63)}

"P: Como é que surgiu o interesse no concurso do CFO?

D: Surgiu o seguinte, é... Eu comecei a advogar em 2012, quando eu formei... Aí eu trabalhava num escritório... Nesse escritório eu tinha uma colega advogada e essa colega tinha um namorado que de vez em quando ia lá... E ele é oficial da polícia aqui do Estado $X$. Aí ele começou a me falar da carreira e tal, falou pra mim fazer que era interessante. Que 
naquela época eu tava advogando e estudando pra concurso. Aí ele me chamou a atenção por CFO. Aí eu... deixei ali no stand-by, ficou ali no meu subconsciente aquela informação. Até quando saiu o edital e eu fiz o concurso. Agora estou aqui..."

\section{Análise 1}

A carreira de oficial parece representar um misto de desejo por status e estabilidade profissional que decorreu da oportunidade proporcionada pelo concurso público. Entretanto, não via a carreira como primeira opção, pois afirma que "posso garantir pra senhora, que os sonhos deles, a priori não era ser oficial de polícia! Porque é uma carreira, que pelo menos pra mim, é uma carreira que... que... que poucos conhecem! Poucos conhecem! Não tem visibilidade, principalmente no mundo dos concurseiros!". Como na fala dos demais cadetes, o interesse inicial pela área policial foi pela carreira de Delegado e não de Oficial da PM. Os participantes da pesquisa, em suas falas, parecem almejar estabilidade, ascensão na carreira e salário.

\section{2 - Avaliação da PM}

\section{Trecho 1 (linhas 72 a 99)}

"P: Hoje você gosta de fazer parte da Polícia Militar?

D: Eu gosto, eu sinto muito orgulho da Polícia Militar. Essa instituição é muito importante pra

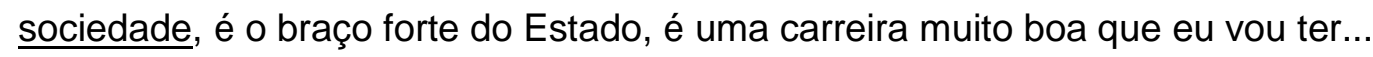

$\mathrm{P}$ : $\mathrm{E}$ nesse sentido, o que você considera como o seu ponto forte na polícia? Sua característica principal, aquilo que você traz de mais marcante?

D: Eu acho que a honestidade, porque a Polícia Militar, pelo que eu sempre... não é minha opinião pessoal... a opinião do senso comum. A Polícia Militar ela é confundida muito com corrupção... Infelizmente. Um dia desses conversei com um dos grandes comandantes e fiz uma pergunta pra ele. Comandante, qual deve ser minha postura pra me tornar um grande oficial? No meu primeiro mês de curso fiz essa pergunta pra ele. Ele me respondeu: 'Olha... Você se tornar um grande oficial? Não tem como se tornar, isso vem de berço! Você tem que ter a.. comportamento ilibado, postura, ética e... Ter boa fé com as pessoas, ser honesto... Por que as pessoas honestas se dão bem aqui na polícia'. Então eu acho que eu tenho a contribuir é isso! A honestidade!

P: Quando esse comandante falou isso pra você, o que você sentiu?

$\mathrm{D}$ : Eu me senti bem! E ele também me disse que isso vem de berço né? Que em tese são valores morais, vem de família... Ele falou dessa questão familiar... Porque não tem como você... pelas palavras dele, não tem como você ser um mau caráter e chegar aqui e começar a trabalhar certinho, em tese... Ele falou que isso vem antes da farda! E ele falou também 
que é pra mim... Pra mim me espelhar nos bons comandantes. No comportamento dos bons... dos bons comandantes. Que ele falou que cada um tem um perfil e falou pra mim extrair de cada comandante o ponto positivo! 'Por exemplo, se um comandante tem uma voz de comando boa, você tenta se espelhar nele... Se o comandante é amigo da tropa, ele quer ta junto do seu subordinado, se espelha nele!' Ele falou pra mim pegar cada característica do respectivo comandante e tentar assimilar aquilo comigo. Isso, isso... dá uma moldagem. Como base na experiência construída na instituição, porque, querendo ou não, nós somos cadetes... Nós vamos nos espelhar no comportamento dos homens de referência... São os nossos comandantes! Então tudo em tese é um pouco copiado na vida... Questão da cultura da polícia também né?"

\section{Análise 2}

Esse trecho mostra a satisfação em fazer parte da Polícia Militar, trazendo como seu ponto forte a honestidade. Ele faz uma reflexão ampla sobre como essa virtude poderá contribuir para sua carreira, buscando se espelhar em alguns comandantes para construir sua identidade e trajetória profissional. É interessante notar o que ele diz sobre a fama da polícia, se justificando: "porque a Polícia Militar, pelo que eu sempre... não é minha opinião pessoal... a opinião do senso comum. A Polícia Militar ela é confundida muito com corrupção...”. Defende, portanto, com base em conversa com um comandante que ele admira, que o mais importante é a honestidade e a ética ("comportamento ilibado, postura, ética").

Em sua fala, Davi se orgulha por ser honesto e ter valores, e concorda com o oficial que Ihe disse que "Olha... Você se tornar um grande oficial? Não tem como se tornar, isso vem de berço! Você tem que ter a. comportamento ilibado, postura, ética e... Ter boa fé com as pessoas, ser honesto... Por que as pessoas honestas se dão bem aqui na polícia'”. Fica aqui a questão: então não há nada que o CFO possa fazer em termos da formação de seus cadetes? O que é mais importante viria "de berço". Vale salientar sua referência à "cultura da polícia", de admirar e seguir o exemplo dos que estão acima dele na pirâmide da hierarquia e que dão bom exemplo. Esse "espelhamento" realmente é algo muito observado no dia-a-dia da PM e muito incentivado nos cursos de formação, tanto em sala de aula quanto nas solenidades e rituais dos quais os cadetes participam diariamente.

\section{3 - Violência: Conceito e Valor}

\section{Trecho 1 (linhas 154 a 172)}

"P: Vamos falar sobre as práticas da Polícia Militar. Você acha que elas envolvem algum tipo de violência?

D: Eu acho que... eu acredito que envolve por parte daqueles policiais mal preparados! Eu 
tenho um lado um pouco desse policial... desse policial que age dentro da legalidade, respeitando os regulamentos... E tenho uma consciência também de policiais... de uma pequena minoria de policiais que tem desvio de conduta.

P: Mas na Polícia Militar como um todo, na prática dela, você acha que existe algum tipo de violência?

D: Não existe! Eu acredito que não existe! Mas isso eu vou... vou... vou constatar mesmo, acho que quando eu sair aqui da Academia. Acho que tem pequenas pessoas, pequenos comportamentos pontualissímos... Algo bem esporádico, isolado, mas que faz a diferença pro senso comum!

P: Entendi!

D: Principalmente com exposição na mídia...Eu... Eu... A violência, ela tem que... O estado tem o monopólio da violência... Em tese, filosoficamente falando! A violência se justifica a partir do momento em que existe uma outra violência. Você tem que usar a violência de maneira proporcional contra a violência que está sendo cometida com você ou contra um terceiro que você está protegendo! É um conceito que não é um excesso! Que a partir do momento que você utilizar a tonfa e dá uma cacetada numa pessoa, isso é violência! Mas dentro da legalidade, a violência é permitida, nada de excesso!"

\section{Trecho 2 (linhas 268 a 285)}

"P: Como você definiria violência?

D: (pequena pausa) Violência? É um pouco teórico assim... Violência... Eu tenho dois conceitos... Primeiro, a violência é atingir alguém de maneira coercitiva... Utilizando instrumentos ou técnicas... Tem a violência legítima que é com base na lei, com base nos princípios legais e morais e admissível pelo direito. Como legitima defesa, estado e necessidade... E tem aquela violência, que seria aquela tradicional, que você atingiria o direito de terceiro indevidamente.

P: Humm... Você pode dar algum exemplo pra gente?

D: No caso de uma resistência ativa, que o agressor vai contra o policial ou um terceiro, o policial impede, não havendo outro meio dentro da circunstância, no caso pode usar arma de fogo! Essa seria a violência legal! Mas também tem a violência ilegal!

$P:$ Qual seria?

D: Seria o abuso do poder! Por parte do policial! Por exemplo, (pequena pausa) é... Tortura... pra... torturar um usuário de droga pra descobrir onde tá o traficante... E também, existe a violência moral. Violência moral, humilhação, xingamento, pressão psicológica... Desnecessária dentro do contexto.

$\mathrm{P}$ : Todas essas seriam formas de violência?

D: Seriam formas de violência! Violência legitima e ilegítima e a violência física e moral!" 


\section{Trecho 3 (linhas 321 a 230)}

"P: Nós sabemos que é melhor prevenir do que reprimir! Mas você acha que é possível prevenir todo tipo de violência?

D: Não!

P: Por que?

D: Eu acho que existem tipos de violência que que tem como você diminuir os índices... Mas tem situações pontuais que não tem como você prevenir! Por exemplo, o homicídio passional... Um homicídio passional, é algo que não tem como prevenir! A pessoa que quer matar, ela vai matar e...não adianta... não tem como você por um policial para cada habitante! Então vai acontecer um homicídio passional. É... O crime de furto também... É muito difícil de você evita-lo. A polícia até tenta, mas nem sempre vai conseguir, é muito imprevisível".

\section{Análise 3}

Inicialmente, Davi parece precisar de um tempo para organizar as ideias sobre uma definição de violência. Aos poucos elabora uma tipologia interessante, e o que antes ele achava que seriam dois tipos de violência se tornam quatro, razoavelmente bem conceituados: a violência legítima versus a ilegítima, e a violência física versus a moral. No geral, orienta suas respostas sobre a questão da violência e a Polícia Militar. No trecho 2 chama atenção o fato dele considerar que a PM enquanto instituição não tem práticas violentas; ele considera que alguns policiais "de forma isolada" utilizam tais práticas. Diferentemente dos demais cadetes, aparece aqui um visão mais idealizada das práticas policiais, e quando ocorrem ações que podem ser consideradas violentas, ele as caracteriza como "desvio de conduta". Faz um grande esforço, utilizando vários termos, para minimizar a relação entre polícia e violência. Segundo ele, "Não existe! Eu acredito que não existe! Mas isso eu vou... vou... vou constatar mesmo, acho que quando eu sair aqui da APM. Acho que tem pequenas pessoas, pequenos comportamentos pontualissímos... Algo bem esporádico, isolado".

Sua fala parece um tanto coerente com a análise anterior onde ele propõe que os valores para paz e violência "vem de berço". Assim, os valores violentos são individuais e dificilmente serão transformados pela instituição PM. Sobre a prevenção à violência, no trecho 3 vimos que ele considera alguns crimes, como os crimes passionais, praticamente impossíveis de serem prevenidos, demonstrando não ter ideia de como uma Cultura de Paz poderia ter um caráter mais amplo e, sim, favorecer as pessoas a resolverem suas diferenças ou disputas de maneira mais pacífica. 


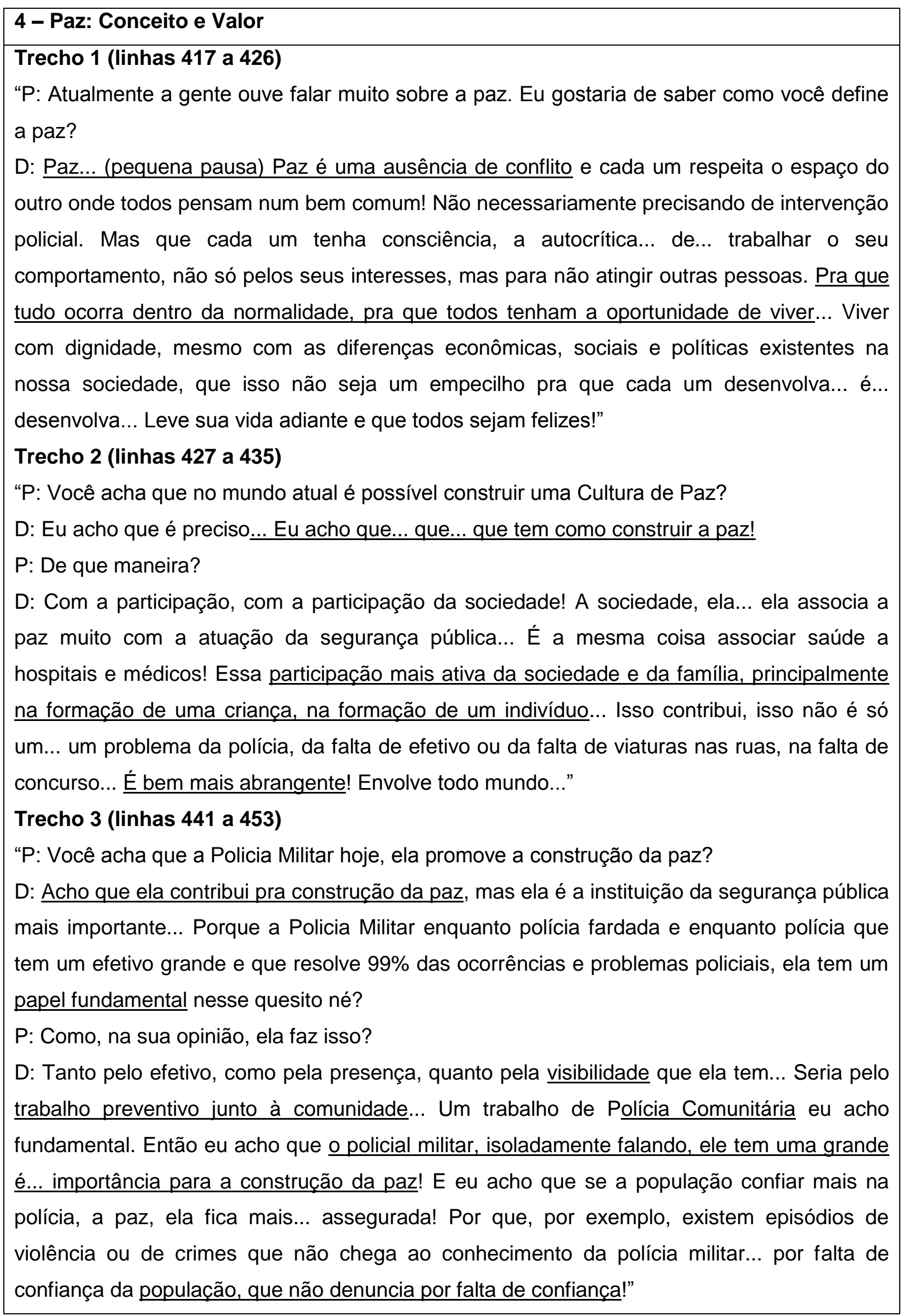




\begin{abstract}
Análise 4
No trecho 1 vemos a clássica definição de paz do senso comum: "é uma ausência de conflito". Usa o termo "normalidade" para designar uma sociedade em paz. Diz que a PM contribui para a promoção da paz. No entanto, os argumentos utilizados são um tanto frágeis, não fazendo menção aos programas institucionais que visam diminuir a violência e promover a paz. Ou seja, parece não compreender o que significa uma Cultura de Paz, acredita que se a população confiar mais na polícia, isso asseguraria mais a paz. Interessante como os conceitos e valores para a paz são do senso comum, também atribuindo à sociedade as próprias dificuldades e problemas da polícia no complicado e difícil diálogo com a comunidade.
\end{abstract}

\title{
5 - Formação do Oficial na PM
}

\section{Trecho 1 (linhas 133 a 147)}

"P: Como você percebe a formação do Oficial aqui na APM?

D: Nós treinamos a parte militar, os comandos né? Mas eu acredito... Porque eu converso muito né? Tenho colegas, tem os ex-militares que a gente conversa muito nos bastidores. A academia, nós estamos sendo formados aqui... Assistimos aula, fazemos educação física, prova... Aqui é como se fosse uma faculdade! É a mesma coisa você fazer a faculdade e for exercer a profissão depois!

$P$ : Entendi!

D: Então eu tenho um pouco essa sensação, que a parte do militarismo vamos ver lá fora... Aqui é importantíssimo, aqui a gente aprende a comandar, tem todo um... Todo um ritual né? De que já faz essa iniciação de comandos né? Mas o... o... o lado operacional mesmo, acho que isso que vai fazer com que a gente sinta mesmo essa profissão!"

\section{Trecho 2 (linhas 222 a 229)}

"P: E como você acha que a polícia orienta os policiais na prática de suas ações?

D: Eu é... eu... eu entendo que o curso de formação, tanto de oficiais e praças da polícia militar... Ele é muito deficitário nesse ponto... Ele deixa muito a desejar na pratica profissional e técnica desses policiais aqui na academia! Eu acredito que a gente tenha matérias muito desnecessárias... E eu acho que... Tem alunos soldados aqui, que até hoje não sabe algemar... Não sabe utilizar a tonfa! Às vezes a habilitação de arma de fogo deles, eles vão dar dez, quinze tiros... Vão cautelar uma pistola permanente pra eles, pra eles atuarem na rua. Então eu acredito que o lado operacional da polícia, é muito... é muito deficitário pra esses novos profissionais." 


\section{Trecho 3 (linhas 385 a 391)}

"P: Em que situação, durante o curso de formação de oficial, questões como essas que a gente tá debatendo aqui, como violência e paz, são conversadas com vocês ou ministradas em aula ou um treinamento?

D: Olha... essa... essa questão violência ou não, eu acredito muito que seja de berço mesmo, vem antes do militarismo! Que a gente tem aula muito teórica... Mas essa questão da violência, ela é mais trabalhada no uso gradual da força! É falado pouco! Mas eu acredito que nesse ponto não seja uma falha da instituição! Porque isso é... Vai de cada um!"

\section{Trecho 4 (linhas 468 a 471)}

"P: E o curso de formação de vocês, você acha que ele promove a cultura de paz?

D: Essa questão de cultura de paz... É... (pequena pausa) Eu acho que é o suficiente! Pra... pra formar a gente assim! Tem a matéria de polícia comunitária, logo no início do curso, eu acho isso muito importante, é... Tem a formação de cada um também, antes do curso, igual eu falei pra senhora!"

\section{Trecho 5 (linhas 480 a 488)}

"P: Você tem alguma sugestão ou ideia, para que o curso de oficiais, ele fosse... Ele fomentasse mais, essa cultura de paz...

D: Eu acredito... eu... eu defenderia assim, uma substituição... (pequena pausa) Remanejamento de matérias! Acho que devia ser $50 \%$ na academia e $50 \%$ na sociedade. Acho que a gente tinha que ser empregado melhor num dado... Junto com a população! (...) A imagem da policia, a confiança da população para com a gente e trabalhar essa questão de paz junto com a população... Não só pra que a população confie na gente, mas que cada um tenha o seu senso de responsabilidade! Por que a população, por mais que ela ás vezes, ela... seja um pouco preconceituosa com a gente, ela respeita muito, ela admira muito a Policia Militar..."

\section{Análise 5}

Davi faz ponderações críticas a respeito do curso de formação, considerando que "deixa muito a desejar na pratica profissional e técnica". Segundo ele, a carga horária deveria ser melhor distribuída, focando mais no preparo técnico e operacional que em aulas teóricas. $O$ trecho 3 traz uma reflexão surpreendente a respeito da violência. O participante acredita mesmo que a questão da violência "seja de berço mesmo, vem antes do militarismo". Ele considera que a pessoa, ao entrar na PM, já tem hábitos, atitudes e valores construídos, e que o curso de formação não pode fazer muito a respeito! Não tem qualquer noção de cultura institucional, o que surpreende em alguém formado em direito no curso superior. Esse pensamento é reforçado no trecho 4, quando considera que a Cultura de Paz advém da 
"formação de cada um também, antes do curso". Segundo este participante, nada pode, nem precisa, ser feito para que a PM de fato contribua para um Cultura de Paz. Sua solução se resume a fazer com que a mudar a "imagem da polícia" para conquistar a "confiança da população". Ou seja, sua visão da sociedade e da missão da polícia é seriamente limitada.

\section{6 - Conflito e suas funções}

\section{Trecho 1 (linhas 499 a 503)}

"P: Vamos falar de conflito agora. O que você considera como conflito?

D: Conflito... Conflito é uma... (pequena pausa) Lembrei até do conceito da faculdade... Que ali, questão de processo né? Dialética contraditória, ele é um conflito de interesses qualificado com a pretensão resistida! Então conflito é a... É o choque de interesse entre duas pessoas! Dentro do Estado democrático do direito ele tem que se solucionar... com base na legalidade!"

\section{Trecho 2 (linhas 506 a 514)}

"P: Em sua opinião o conflito pode ser positivo?

D: Ele pode ser positivo! Com certeza!

P: Por exemplo...

D: Construindo experiências para que sejam evitados novos conflitos, o próprio policial que vai tentar mediar esse conflito, que pode ser de uma maneira pacifica... Ele cria experiência com o conflito, para evitar novos conflitos e também para trabalhar outros conflitos!

$\mathrm{P}$ : Você tem um exemplo de conflito positivo?

D: Aqui no CFO mesmo, muitas vezes as ideias divergentes, elas criam um conflito na hora, que depois se torna positivo. A gente aprende com aquilo."

\section{Análise 6}

Nesse trecho, novamente, o participante recorre a uma definição do Direito para falar sobre o conflito, e acaba reduzindo a questão ao "choque de interesse entre duas pessoas". Considera que o conflito pode ser positivo, apenas e simplesmente porque a "experiência com o conflito, (é boa) para evitar novos conflitos") Não tem a menor noção do que venha a ser um conflito construtivo e promotor de desenvolvimento humano ou social...

\section{7 - Análise das imagens}

\section{Imagem 1 - Civil chutando o rosto de um policial militar (linhas 517 a 522)}

"P: O que você sente quando visualiza essas imagens?

D: Indignação! Eu sinto indignação! Por que esse caso é do civil Serra né? Eu vi no jornal... Nesse caso aí... Um policial desarmado, não tava atacando o torcedor e sofreu essa injusta 
agressão! Inclusive, o policial aí, se não me engano, é cabo da policia... Tem mais de 10 anos de caserna... Então não deixa de ser, em tese, um pai de família que tava ali trabalhando e tentando garantir a segurança... da população!"

Imagem 2 - Policiais militares agredindo um civil (linhas 534 a 541)

"D: É um caso evidente de abuso de poder, por parte da polícia militar, e também nesse caso aí ta envolvidos soldados voluntários... e sem dúvida nenhuma, foram mal preparados aqui dentro da academia, de acordo com minha opinião. E... Estavam totalmente errados, e principalmente, não só eles, mas talvez o comandante deles! Dessa situação... Eu não sei se eles agiram de forma isolada ou se tavam sendo comandados por alguém... Mas aí é algo totalmente... é... (pequena pausa) Comportamento totalmente... é... revoltante... Não é cabível na nossa sociedade... Eu sinto vergonha! Porque eu sou policial militar e isso me reflete... Pra minha família... Tudo que envolve policial me envolve..."

Imagem 3 - Coronel da PM agredido em uma manifestação (linhas 551 a 559)

"D: Essa... essa imagem... a do coronel... Aquele coronel de São Paulo... Também sinto muita indignação! Na mesma proporção do que o... Do que naquela primeira imagem, do... soldado... do cabo agredido no estádio! Pelo que eu tenho notícias dessa imagem... To analisando, associando a imagem às notícias que eu tenho... Foi um coronel que foi agredido numa manifestação que teve. Então... um senhor que dedicou toda a sua vida a uma instituição militar e foi covardemente agredido por... por uma população que não tem sensibilidade! Porque militar... O militar ele é um profissional totalmente diferenciado dos demais. A formação... A formação dele é mais rígida, o comportamento social dele, ele tem que abrir mão de muitas coisas... E ele foi covardemente agredido... pela população!"

Imagem 4 - Policiais fazendo contenção de um civil em manifestação (linhas 584 a 587) "D: (pausa média) Essa imagem, sinceramente, eu não sinto nada! Eu acho que... Acho que... Talvez, antes de entrar pra polícia eu sentiria um sentimento de indignação... contra os policias! Mas hoje eu acredito que a ação policial ela tem que ser estudada dentro daquilo que exigiu a intervenção! Meu pensamento dessa imagem é uma sensação totalmente imparcial, assim..."

\section{Análise 7}

O sentimento de indignação e revolta nas cenas de policiais agredidos é bem expressivo tanto em palavras quanto nas expressões corporais. Podemos perceber, pelas falas, que já existe uma grande identificação com a classe policial e o sentimento de pertença ao grupo já está instalado, apesar do pouco tempo de ingresso. Em uma proporção menor, demonstra repúdio e desaprovação pela imagem 2, tendo dificuldade de admitir e aceitar a ideia de que ocorra violência por parte de um policial. Questiona, inclusive, o comandante deles, e diz 
sentir intensa vergonha. Isto faz sentido, pois durante a entrevista ele várias vezes se esforça para reduzir e minimizar a existência de qualquer tipo de violência por parte de policiais.

Diante da terceira imagem, ele defende o coronel e coloca a culpa da agressão não em um indivíduo específico que agiu de forma covarde, mas generaliza e culpa a "população". Isto, em termo de processos de significação é extremamente perigoso e representa uma armadilha semiótica: coloca a PM contra uma "população" covarde e brutal (ou seja, todas as pessoas presentes naquela manifestação) contra a qual a PM precisa se posicionar (quem sabe até, neste caso, fazer uso do que ele considera como violência legítima?. Diante da última imagem, ele não se abala e acha tudo normal, posição semelhante ao que foi expresso pelos demais cadetes.

\section{8 - Análise do vídeo}

\section{Trecho 1 (linhas 605 a 617)}

"P: O que você sente quando assiste esse vídeo?

D: É o... descrédito né? Que a população tem para com a gente, a Policia Militar! Eu acho que eles tentam, em algumas situações, culpar a PM, achar um responsável por um problema social que acontece! E a polícia em tese, está protegendo quem a está prejudicando... Seria o Estado, ou um ato de um governador, de uma autoridade qualquer... Então a polícia, ela é muitas vezes, mal interpretada... Por essas imagens aí eu pude perceber, que a polícia não agiu com excesso; ela tentou reestabelecer a ordem pública e foi humilhada, ultrajada ali pela população! Lógico que o policial tem que ter o preparo psicológico e emocional pra... aguentar xingamentos, humilhações, e isso não deve nos atingir, naturalmente, mas isso é ruim porque externa a... a consciência de uma população sobre a instituição. Não que o policial seja atingido, mas essa é uma imagem que a sociedade tem da gente!

$P$ : Como é que você se sente? Assistindo...

D: Eu me sinto envergonhado com a nossa comunidade, com a nossa população..."

\section{Análise 8}

O sentimento preponderante durante o vídeo foi de injustiça, parecendo triste. Em alguns momentos pareceu apreensivo e depois relatou certa indignação e, por fim, vergonha. Como o sentimento de pertença ao grupo já está bem estabelecido, ficou evidente o sofrimento ao ver os colegas policiais na situação de humilhados: "humilhada, ultrajada ali pela população". Ele prossegue dizendo "essa é uma imagem que a sociedade tem da gente!". Aqui, mais uma vez, chama a nossa atenção o fato de que ele tende a generalizar, usando os termos "pela população" ou "pela sociedade", estabelecendo um antagonismo exagerado e perigoso, 
ao invés de reconhecer que existem pessoas revoltadas e agressivas, mas não são todas as pessoas assim. Ao generalizar, tende a colocar a população como potenciais inimigos da polícia. Percebendo as pessoas desta maneira, fica difícil atingir aquilo que ele mesmo diz desejar: que os policiais sejam bem aceitos pela população...

\section{9 - Sugestões e ideias para a Polícia Militar promover a Cultura de Paz}

\section{Trecho 1 (linhas 638 a 654)}

"P: Pra finalizar a nossa entrevista e... lembrando que nossa entrevista é sigilosa, você tem mais alguma ideia, sugestão ou recomendação para a instituição Policia Militar, enquanto instituição social pública, como você bem colocou... Para promover a Cultura de Paz?

D: Eu acho que a polícia, ela tinha que se misturar mais, da população... Isso é fundamental, eu percebo assim, comigo... Por que o poder de um policial é muito grande! O policial tem que utilizar mais essa... essa parceria com a comunidade, que infelizmente existem muitos policiais rançosos! Que querem separar o militarismo da população civil e as coisas não são bem assim! A gente tem que tá mais próximos das pessoas, fazer mais projetos, por exemplo, utili... ir mais nas escolas... Eu to te dizendo muito essa expressão mais é de propósito. Uma policia comunitária mais efetiva! Com todos os seguimentos sociais, porque eles respeitam a gente e admiram! Outro ponto também seria a estruturalização da família. Isso contribui muito com essa questão de... de conflitos... Dentro da família, dentro... da população mesmo. Mas assim, eu enquanto policial, eu posso contribuir pra isso!

$P:$ Você acha que é uma responsabilidade individual ou da instituição?

D: Não... Cada um tem a sua responsabilidade! Então eu como policial tenho o dever de trabalhar certinho... Tanto no exercício das minhas funções como fora dela... Então, cada um constrói sua segurança pública!"

\section{Análise 9}

Sobre o que fazer para melhorar a PM no sentido da construção de uma Cultura da Paz, o cadete Davi não tem a menor noção. Reitera em sua fala que tudo é da alçada do individual, não tem nada a ver com a instituição em si. Segundo ele, é "Cada um tem a sua responsabilidade!" ou então, "cada um constrói sua segurança pública!”. Impressiona sua falta de visão crítica e visão institucional, quando comparado aos outros dois cadetes. Vale notar, também, sua falta de entendimento com relação à pergunta feita pela pesquisadora quando ele afirma que "Outro ponto também seria a estruturalização da família. Isso contribui muito com essa questão de... de conflitos...". Fica difícil se saber o que ele quer dizer com isto...Será que ele acredita que a PM pode promover a "estruturalização" da família? O que ele quer dizer com o termo inventado? Certamente esta não é nem pode ser considerada uma missão da Polícia Militar. 


\section{2 - GRUPO FOCAL - CADETES}

Nesta etapa da pesquisa, participaram os cinco cadetes que foram entrevistados individualmente. Pela necessidade de um recorte dos dados, selecionamos, para fins de análise neste estudo as três entrevistas individuais mais ricas em termos dos objetivos da pesquisa. No entanto, no grupo focal, os posicionamentos de todos os cinco participantes cadetes foram considerados, o que enriqueceu a qualidade dos dados da pesquisa. Segue abaixo a análise dos posicionamentos apresentados pelos cadetes, realizada por trechos de conteúdos específicos com base nos dilemas e questões propostas para o grupo.

\section{Trecho 1 (linhas 7 a 32)}

"PESQUISADORA: Bom, então eu vou passar pra vocês uma "história", que nós vamos ler juntos e logo em seguida vamos discutir os posicionamentos de vocês a respeito (lendo a história). Qual é a tarefa de vocês? Colocar os 6 personagens em ordem decrescente de culpa pela morte de Maria. Em $1^{\circ}$ o mais culpado e em $6^{\circ}$ o menos culpado pela morte de Maria.

ESTER: Primeiro os bandidos. Pode ir falando?

P: Pode!

ANDRÉ: O próprio marido, João!

MOISÉS: Não! O maior responsável são os bandidos!

E: Primeiro os bandidos!

A: Isso! O marido, em segundo lugar, primeiro os bandidos. João por ter sido o personagem secundário aí... se não fosse essa desídia dele, ela não teria procurado Paulo. Na minha concepção!

LUCAS: Eu penso que o segundo seria Maria

DAVI: Eu também penso que o segundo seria Maria... ela mesma

E: Por que seria Maria?

L: Porque foi ela que foi procurar...

M: Ela que passou pela ponte...

E: Procurar o que? Ela tinha que ir embora pra casa!

$\mathrm{L}$ : Mas ela tava traindo o marido dela do outro lado do morro!

$P$ : Aqui fala que ela estava traindo?

E: Pois é... (risos) eu também não entendi

A: É... aqui não fala da questão da traição...

E: Hora nenhuma fala de traição! 


\begin{abstract}
L: Então, que desespero é esse pra ir embora? Aqui fala que ela se sentiu abandonada e procurou Paulo. Dá a entender que ela procurou ele pra quê? (risos)"

\section{Análise 1}

Nesse primeiro trecho, inicia-se uma discussão na qual a possível traição de Maria é a pauta. O julgamento moral da mulher aparece carregado de emoção nas expressões, na entonação vocal e no comportamento não-verbal dos participantes analisado a partir das imagens de vídeo. Começa uma divisão no grupo onde a cadete Ester acusa o marido de abandono, sendo ele o segundo maior responsável pela morte. Enquanto os demais cadetes acusam Maria de ter traído o marido e ter assumido o risco de passar pela ponte, para evitar que o marido desconfiasse de algo. Interessante ressaltar que, independente dessa discussão, todos consideram os bandidos como os maiores culpados, o que já sinaliza um grau de coerência no grupo.
\end{abstract}

\title{
Trecho 2 (linhas 75 a 99)
}

"D: A questão de Maria estar em 2 o lugar eu concordo com vocês, mas...

E: Eu não concordo de jeito nenhum!

D: Mas não por essa justificativa... mais pela justificativa da vitimologia, porque ela se expôs a uma situação de perigo. Claro! Ela poderia ter tido várias ajudas aí pra chegar ao destino dela, mas eu não colocaria essa questão aí que ela estava na casa de Paulo

$P$ : Então você acha que ela foi irresponsável?

D: Acho sim! Ela poderia ter esperado, aguardado, ou chamado uma força de segurança...

L: Ou ligado para o marido...

D: Ou tentado outras alternativas. Então ela se expôs! Essa questão da vitimologia mesmo. É uma área da criminologia que fala que há responsabilidade da vítima num acontecimento desses. Mas claro que a responsabilidade imediata é do agressor, mas a vítima tem sua parcela também.

M: Eu colocaria em 1ํ lugar os bandidos, claro! Mataram ela, estão ali praticando crime. Em $\underline{20}$ lugar, ela própria porque... ela não esgotou todos os meios que ela tinha pra passar ali naquela ponte. Ela poderia ligar para o marido, independente do que ela estava fazendo, ela só não podia atravessar aquela ponte. Ela podia ter ligado e falado: "oh, deu problema aqui não vou passar aqui na ponte". Então, em $2^{\circ}$ lugar a culpa é dela mesma. Em $3^{\circ}$ lugar o taxista, por ter tido uma posição muito pouco humana, poderia ter feito um desconto pra ela. Em 4ํlugar o Paulo, porque o Paulo tava se beneficiando da situação, ou no mínimo ele tava com ela e não quis ajudar. Ainda falou que o problema era dela, isso é muito ruim. Em $5^{\circ}$ lugar o amigo dela, porque ele até foi lá com ela, mas claro que a gente não pode exigir 
heroísmo de ninguém. E em 6o lugar o João, acho que o João não tem culpa nenhuma nisso aí..

D: Eu também! Eu também!"

\section{Análise 2}

Davi traz, nesse trecho, uma explicação "jurídica" por colocar a própria Maria em segundo lugar como responsável por sua morte: "pela justificativa da vitimologia, porque ela se expôs a uma situação de perigo". Para reforçar seu pensamento, ele argumenta, como sugestão, que ela poderia ter "chamado uma força de segurança...". Dessa forma, ele reconhece que profissionais de segurança pública, deveriam ter sido chamados para assumir a responsabilidade sobre o fato. Moisés também faz sua análise do escalonamento de culpa, reiterando a análise do colega.

\section{Trecho 3 (linhas 128 a 153)}

"M: Na sua concepção o João é o segundo?

E: Claro!

M: Na da senhora também, aposto!

P: Não... não tenho nenhuma opinião, quero ouvir vocês.

M: É o pensamento feminino...

E: Eu colocaria assim: primeiro os bandidos, o segundo João, por quê? Porque ele era marido dela, ele que tinha que tá protegendo ela, ele que é a pessoa mais intima dela, independente do que ela esteja fazendo. Ainda (ênfase) que ela esteja traindo ele, a obrigação é dele gente! (riso de M). Não é de um amigo, ou de uma terceira pessoa, nem do taxista! Quem tem que tá do lado dela protegendo o tempo inteiro é ele!

M: Coitado do cara gente...

E: Coitado nada, ele é casado! Ele é casado (ênfase)! Uai, casado é casado!

P: Segue o raciocínio...

E: João em segundo lugar, terceiro lugar o taxista porque era um trabalho e ele iria receber por isso, o que pesa mais do que os demais, não que seria uma obrigação, igual eles falaram... Mas é o que pesa mais, ele tava recebendo por isso! Depois o Paulo, que foi... Assim, que poderia tá ajudando ela e não ajudou, e o amigo por último porque ele...

L: Ainda tentou ajudar...

E: Foi, ainda tentou ajudar! E ela é uma vítima! Ela é uma vitima de toda essa história! Por mais que ela estivesse traindo o marido... É igual aquela história do estupro das mulheres lá... Você tá usando uma saia curta, você é vitima de estupro?

D: Não, mas isso não pode ser comparado... 
E: É a mesma situação dela aqui! Se por acaso ela tivesse realmente traindo o marido, ela tinha que passar por isso? Morrer apanhando?

D: Não... Não...

E: De uns bandidos que não tem nada a ver? Só por que ela PODERIA estar traindo. Uma coisa que vocês estão interpretando pra mal dela e não pra mal dele!

D: A gente tá fixando desde o...

E: Que isso gente! Vocês tão pensando igualzinho eles..."

\section{Análise 3}

Observamos nesse trecho que o cadete Moisés explica o argumento da colega Ester sugerindo que pesquisadora, como mulher, também culparia o marido, sendo esta a tendência feminina. Esta percebe a manipulação e retorna o foco para a discussão do grupo. Parece haver aqui uma tentativa de seccionar o grupo por gênero, o que não é produtivo e direcionaria a discussão para uma bipolaridade. Em seguida, Ester reforça sua argumentação trazendo uma situação comparativa em relação à questão do estupro. A fala dela é bem contundente nesse sentido:"Se por acaso ela tivesse realmente traindo o marido, ela tinha que passar por isso? Morrer apanhando?" Parece haver aqui uma tentativa de mobilização emocional, que é rechaçada pelos colegas ('Não, mas isso não pode ser comparado...').

\section{Trecho 4 (linhas 436 a 464)}

"M: Vamos pensar num exemplo diferente... Vamos supor que é a filha querendo voltar pra casa pro pai não brigar com ela! É... Uma filha que tá com namoradinho do outro lado da rua... É, e quer voltar pra casa por causa do pai! A culpa é do pai que não deixa ela namorar? E: Não, não, não...

M: Quer dizer que se ele deixasse ela namorar...

E: A culpa seria do pai se ele abandonasse a filha!

M: Não! A situação é o seguinte, o pai não deixa a filha namorar...

E: Aí é diferente!

M: Não, é a mesma situação!

E: Claro que não, aqui tá falando que o marido abandonou a esposa! Não... Nossa, Moisés, não! Tem nada a ver!

M: Pensa, pensa na situação na situação do pai...

E: Humm... O pai, é obrigação dele não deixar ela namorar uai!

M: Se você fosse mãe, aí você tem uma filha, você não deixa sua filha namorar...

E: Amm...

M: Aí a sua filha deixa de ir pra escola um dia e vai pra casa do namorado! Sua filha deixa de 
ir pra escola um dia e vai pra casa do namorado dela, e na volta ela é atropelada e morreu! "Ah, se minha mãe deixasse, eu não precisaria ir no horário da aula, inclusive ela mesma me levaria e me buscaria!" A culpa é sua então?

E: Não, claro que não! Mas é totalmente diferente!

M: E você nem sabia que ela tava na casa do namorado!

E: Totalmente diferente!

M: É a mesma história! Só o exemplo que é diferente!

E: Não!

L: Tem uma segunda história aí não? (risos)

$\mathrm{P}:$ Tem sim! Mas temos que encerrar essa aqui!

E: É que são pensamentos muito diferentes!

D: A Ester levou pro lado emocional! "

\section{Análise 4}

Utilizando da mesma tática de mudar o exemplo pra tentar convencer o colega, Moisés traz uma outra história pra tentar sensibilizar Ester de que o marido não tem culpa. Ela não aceita a comparação e argumenta que são exemplos diferentes. Interessante observar como o debate fica acirrado e os participantes adotam posicionamentos firmes, sem abrir mão de sua opinião sobre o caso. Lucas, numa tentativa de fuga do debate, pergunta: "tem uma segunda história aí não?" E Davi complementa "a Ester levou para o lado emocional!". A riqueza desse dilema no contexto do grupo dos cadetes foi observar que as emoções afloraram e eles tomaram posicionamentos de defesa ou ataque, mas também considerando a complexidade do dilema em relação aos personagens citados na história, fazendo isto na medida de suas experiências e julgamentos morais.

\section{Trecho 5 (linhas 473 a 482)}

"L: E o que eu pude perceber assim, eu entendi o que a Ester tá falando, e aí entra no que o Davi tava falando! Não sei se é porque ela é casada... Sei lá, ela tá defendendo o lado da Maria, mas por um lado ela tem razão, não tem como você mensurar. Acho que vai muito do que você acredita também, o que eu penso aqui sobre esse texto, os principais culpados são os bandidos, o resto não tem como mensurar! Se foi ela, se não foi, porque ela não fez nada de errado, pelo menos no texto não fala que ela fez nada de errado. Ou João também... não tem como colocar Maria como culpada!, Os principais culpados são os bandidos por terem tirado a vida dela! $O$ resto você põe assim aleatoriamente.

$\mathrm{P}$ : Esse é o consenso do grupo?

Cadetes: Isso!" 


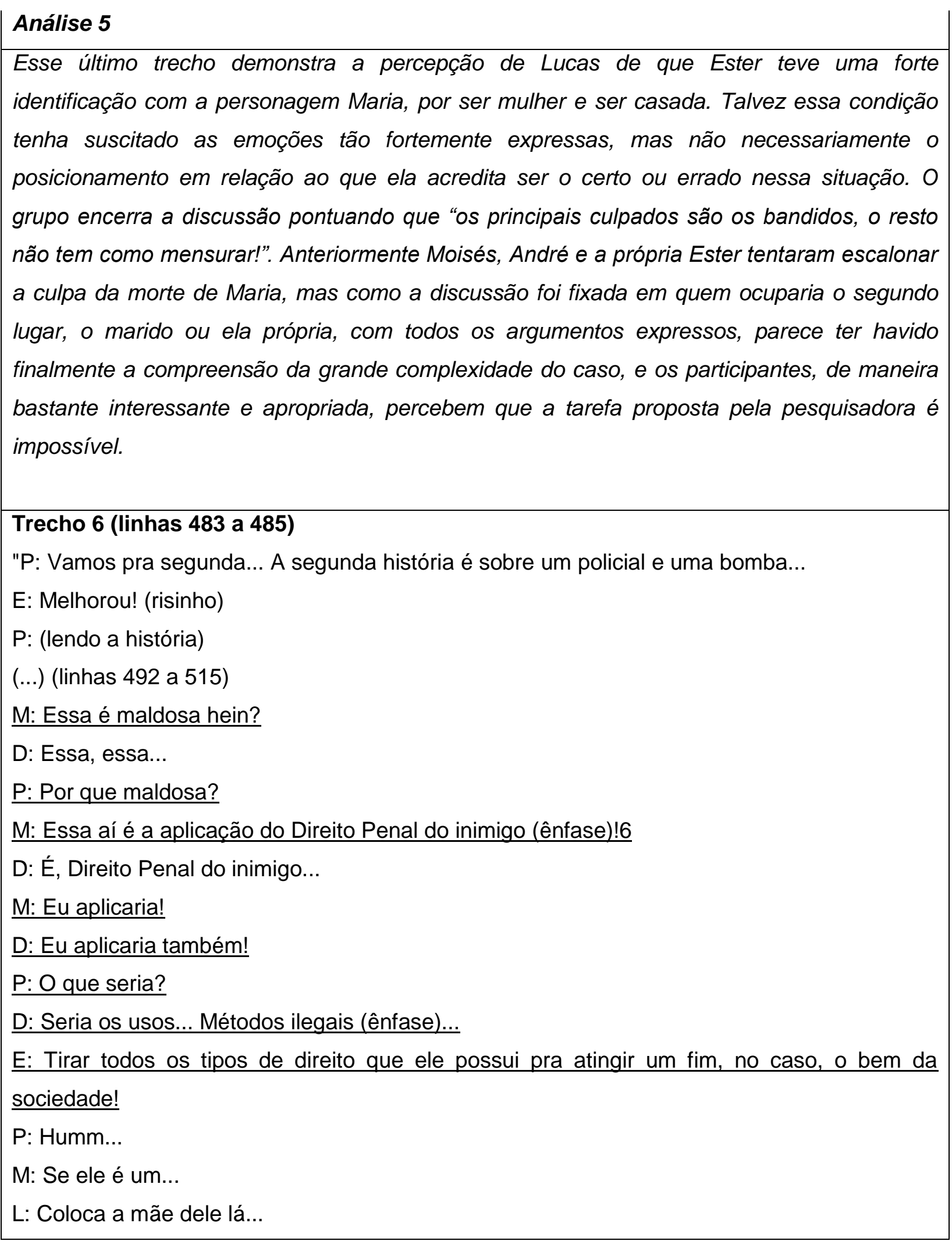

6 Direito Penal do inimigo é uma teoria enunciada por Günther Jakobs, pensador alemão que a sustenta desde 1985 com base em políticas públicas de combate à criminalidade interna e/ou internacional. A qual está sustentada em 3 pilares: (a) antecipação da punição; (b) desproporcionalidade das penas e relativização e/ou supressão de certas garantias processuais; (c) criação de leis severas direcionadas à terroristas, delinqüentes organizados, traficantes, criminosos econômicos, dentre outros, dessa específica engenharia de controle social. Fonte: www.wikipedia.org 
M: Fala que ele é um assassino, que já matou várias pessoas...

E: E que tem intenção de...

M: E é terrorista... Infelizmente...

D: Que tem uma bomba... Isso daí foi até tema de filme...

M: O meio de atuação com ele infelizmente tem que ser um pouco diferenciado né? Entre a vida dele e a de centenas, a de centenas prevaleceria né?

L: Isso daí é complicado...

P: Então o que vocês fariam pra tirar essa informação dele?

L: Tudo! (riso) Pau na moleira! Tudo! (risos)

E: Eu acho que tem que ser gradativo... Gradativo, primeiro muita conversa... depois esses outros métodos."

\section{Análise 6}

Esse trecho nos mostra um certo alívio dos participantes em mudar o foco da discussão, pois no dilema anterior ela estava muito acirrada e bipolarizada. No entanto, também apresentam certo desconforto quando a história é apresentada: "Essa é maldosa hein?". E logo em seguida, apresentam seus posicionamentos, não demonstrando nenhum pudor pra falar que utilizariam a tortura com meio para obter as informações do terrorista, inclusive apresentando justificativa jurídica para seus argumentos.

\section{Trecho 7 (linhas 521 a 540)}

"L: Eu também tentaria da mesma forma! Usaria todos os meios pra que ele não sofresse abuso, o que fosse... Todos os meios, tentar conversar e tarárá, buscar profissionais nessa área, se tivesse tempo claro! Pra tentar extrair essa informação, mas senão tivesse jeito... infelizmente acho que teria que optar pelos meios mais radicais...

M: Chamar o capitão X (risos). Dar uma "pressão" nele...

P: O que vocês chamam de "meios mais radicais"?

L: Usar de tortura... Esse tipo de coisa...

A: Principalmente tortura, está ligado... É... Muito embora não seja aceitável, por ser até equiparado a crimes hediondos... Essa situação, para resguardar a vida de pessoas, considerando o próprio assassino...

E: Porque assim, na verdade, é mais fazendo uma comparação entre vários bens, várias vidas e uma vida só, e aquela vida só tá colocando em risco muitas! Então a gente exclui ali os possíveis direitos que ele tem pra salvar a vida de outros.

D: Capitã, esse termo tortura, a gente tá usando ele, essa palavra, e eu também usei, porque quando a gente passou no concurso, a Doutrina Jurídica ela dava como exemplo mais ou 
menos esse cenário, idêntico, e que a gente utilizava a tortura pra obter confissão, para obter informações... A tortura seria um meio legitimo, por isso a gente tá usando essa expressão. Mas não que isso seja normal, e legal, e disseminado.

E: Mas é um caso extremamente... Pontual!"

\section{Análise 7}

Aqui o grupo continua explicando e argumentando sobre os métodos que usariam, numa escala progressiva da força, chegando até a tortura. Vale ressaltar a fala de Davi, que tenta explicar que a tortura não é uma prática comum ou "normal", ela seria utilizada como último recurso e Ester reforça "EXTREMAMENTE pontual". Temos a impressão que nesse segundo momento, eles refletem melhor sobre a discussão em pauta e tentam considerar mais aspectos do caso antes de se posicionarem em relação à utilização da tortura. No item anterior esse posicionamento ocorreu de forma natural, sendo a primeira resposta apresentada. De qualquer maneira, sentem-se relativamente à vontade para justificar o uso da tortura.

\section{Trecho 8 (linhas 560 a 576)}

"D: A gente não pode discutir a vida dele, porque a vida dele não tá em discussão.

E: É!

D: O que tá em discussão é integridade física, psicológica e etc.

E: É, Uhum!

D: Porque ele vivo ou morto, eu prendi ele... Vivo ou morto a bomba vai estourar de qualquer jeito!

E: De qualquer jeito! É! Tá em jogo a integridade física dele com várias vidas!

D: Exatamente!

$\underline{P}$ : Então nesse caso seria "legítimo" utilizar esses métodos?

D: Isso, seria legitimado, inclusive tem reconhecimento... respaldo doutrinário!

E: Mas é claro que com muita cautela!

M: Essa questão aqui, ela é mais fácil que a outra. A outra é mais polêmica, (riso) essa aqui eu creio que ela só tem uma resposta!

L: Só tem uma resposta!

M: Responder diferente aqui ou tá mentindo ou escolheu a profissão errada! Não entendeu a energia que o caso requer...

E: É a que a gente tá aqui pra justamente isso, é o Bem Social...

(...) ( linhas 586 a 592)

A: O objetivo dessa tortura não é a tortura em si, fazer o mal, entendeu? Mas obter algum tipo 
de informação que vai salvar vidas!

\section{D: É uma "Tortura Ética!"}

A: É... (risos)

P: Existe esse termo?

D: Não, é brincadeira!

M: Neologismo!"

\section{Análise 8}

Nesse trecho final, o grupo pondera sobre a questão da vida do terrorista e sua integridade física, chegando a fazer uma comparação numérica: 1 vida do terrorista $X$ várias vidas, das potenciais vítimas da bomba. Davi fala sobre a legitimidade do ato da tortura, trazendo embasamento jurídico, Moisés fala que "Responder diferente aqui ou tá mentindo ou escolheu a profissão errada! Não entendeu a energia que o caso requer..." e Ester reforça que o objetivo de toda a ação seria o "bem social". O que mais se destaca nesse trecho é a utilização do termo "Tortura Ética" trazido por Davi, que depois de questionado é explicado como um "neologismo", ou seja, o grupo se apodera dessa ferramenta para "legitimar" seus argumentos de que, no caso em debate, a tortura seria aceitável e legalmente amparada. Observamos que o grupo fica muito à vontade para se posicionar nesse caso; o pensamento é praticamente unânime, e buscam fundamentos para embasar seus argumentos.

\section{Trecho 9 (linhas 594 a 615)}

"P: Agora são algumas perguntas que eu quero ouvir a opinião de vocês. A primeira delas, é que durante esse tempo aqui na academia que práticas e regras mais estão ajudando vocês a se formarem como oficiais? Por que vocês chegaram do mundo civil... e estão conhecendo o militarismo agora. Então, que regras e normas da APM estão mais ajudando vocês a serem bons oficiais?

L: Regras?

M: Essa daí também é uma das difíceis né?

D: Bons oficiais?

E: Ah, eu acho que disciplina!

$P:$ Disciplina?

E: Talvez, pelo menos é o que eu penso que é a maior qualidade e poderia ser até o maior defeito né? Que seria a hierarquia! Que é uma das coisas que ajudam a ser um bom oficial, mas dependendo da ponderação de como vai ser... Também prejudica!

L: Já esse lado da hierarquia, ao meu ver, o bom seria o exemplo! Que nós... Pelo menos eu acredito nisso, eu e a Ester já tínhamos conversado isso antes, nós miramos aqui nas 
pessoas, nos bons exemplos, as pessoas que são humanas, que são... Que tem inúmeras qualidades que nós não vemos em outras Por exemplo, tratar outra pessoa com falta de educação... Esse tipo de coisa, eu acho. Nesse caso se enquadraria na hierarquia, ou seja, ele é superior a outra pessoa, mas trata essa pessoa com dignidade! Quando ele tiver que ser duro, ele vai ser duro sem faltar com o respeito. Não é porque ele tem uma estrela no ombro que vai usar disso pra querer humilhar a pessoa e ser bocal por isso! Trazendo pro lado da hierarquia, é a coisa que mais me ensina aqui dentro, que eu mais observo!"

\section{(...) (linhas 632 a 633)}

"E: Aí dependendo da forma que ela é usada, ela pode ser o maior defeito!

D: Sendo que... Nem todos dão bom exemplo né?"

\section{(...) (linhas 635 a 639)}

"L: Eu acho que o contato com o público lá fora, pra mim foi o melhor assim... Nós aprendemos a lidar com pessoas... Isso pra mim foi o melhor assim... Porque você tem uma imagem, por exemplo, quando você fala, vou usar o exemplo que eu vivi certo? Do Estádio de Futebol. Você tem uma imagem que eles te passam de algumas pessoas, que ali dentro só tem bandido!"

\section{(...) (linhas 647 a 650)}

"Acredito que na maioria do tempo, por ser nosso tipo de policiamento, nós vamos trabalhar com pessoas ruins, porem nós vamos atender também pessoas boas. Você não vai tratar uma pessoa boa, um pai de família, com falta de educação com... Que seja, como você trataria uma pessoa que digamos, não é tão boa!"

\section{(...) (linhas 654 a 677)}

"A: Considerar a humildade, porque pra tá aqui, pra viver esses dois anos, principalmente é... Do mundo que nós viemos, atualmente, ou seja, a maioria já, já são formados, já tem uma concepção de como ser profissional, como ser pessoa... E entra aqui, ás vezes a gente tem que dar dois passos pra trás pra dar três pra frente! Saber agir com paciência, agir com humildade, pra dar conta disso daqui. Então principalmente a questão da... O aprendizado maior, por enquanto, humildade!

M: É... Prática... Que eu acho muito interessante é que aqui, é... Aqui se pratica honestidade, no âmbito militar. Não é só na fala! "Ó, tem que ser honesto aqui..." A gente vê a pratica da honestidade aqui dentro. Isso é uma grande característica do militarismo! É... Eu presenciei uma vez, uma servidora daqui repassando uma ordem pro capitão $X$, uma ordem do vicegovernador do Estado! E o capitão falou: "Não, não vou cumprir porque é mentira!" Aí ela repetiu: "Olha, é uma ordem do vice governador do Estado! E e ele vai tá ali olhando!" De fato ele estava lá no palanque. Ele falou: "Olha, eu prefiro omitir essa questão, do que mentir. Eu prefiro omitir, não falar nada a respeito, qualquer que seja a ordem, do que mentir, porque 
não é verdade e se não é verdade eu não vou falar!"

P: Uhum...

M: Esses... de certa forma esses valores, como diz o coronel $X$, né? Esses valores realmente existem aqui... É... Eles são... A maioria que usa a farda tem esses valores, a verdade na prática. A pratica que eu mais admirei aqui foi a verdade! $E$ a experiência... $\underline{A}$ experiência que eu vejo mais interessante aqui é ver pessoas que falam da hierarquia né? Como vocês estão falando da hierarquia né? É ver pessoas que estão na parte de cima, no comando, ou seja, em cima na hierarquia... E com humildade, tranquilidade... É... Citar nome tem problema?"

(...) (linhas 687 a 695)

"M: Eles tem um jeito de falar diferente, um jeito de tratar as pessoas diferente... Não é que frouxo! Se for preciso usar... O posto, usa, sabe usar! Não é que é frouxo, mas é... Gente que eu não imaginava que existia aqui dentro!

P: Uhum...

L: Eu também...

M: É... Achava que aqui ia ser só... ia ser... Seria um lugar bom, mas seria aquela seriedade extrema, eu tinha assim uma visão de que sorrisos seriam poucos né? E vendo, vendo... Como experiências, vendo pessoas humildes em postos altos, a gente tem esperança disso daqui! Por essas pessoas..."

\section{(...) (linhas 713 a 727)}

"D: A prática interessante que eu... Que me ajudou bastante, tanto interno quanto meio social também, é a questão do respeito que eu aprendi aqui a ter! Porque na nossa condição, nós já entramos muito respeitados aqui dentro... E temos que respeitar também, especialmente os nossos superiores, dentro da hierarquia né? E também devemos respeitar nossos subordinados, nossos pares... Tudo isso entra num contexto... Então, depois que eu entrei aqui na academia, eu passei a ser um ser humano melhor. Nesse aspecto de saber respeitar, de saber... É... o espaço de cada um, até aonde eu posso ir, o limite de cada um, até onde o meu direito acaba e vira dever...

$\mathrm{P}:$ Ummm...

D: Aquela situação toda! Por exemplo, nessas situações aqui, o Moisés, ele assumiu a chefia geral do CFO hoje. Mas ele pegou de alguém, semana que vem vai ser outro... Então, querendo ou não, ele tá num cargo de destaque hoje, mas semana que vem vai ser outro, então... Hoje ele deve ser respeitado, semana que vem, ele vai respeitar, e assim sucessivamente. E isso colaborou muito pra... Pra minha formação pessoal e institucional também." 


\begin{abstract}
Análise 9
Nesse trecho o grupo expressa seus posicionamentos a respeito das normas e regras que mais consideram que auxiliam na formação do oficial. A questão da hierarquia parece incomodar a todos, pois, logo de início, eles expressam que muitas vezes ela não está associada com o bom exemplo por parte do oficial superior. Ester enfatiza que a hierarquia é, para ela, a maior qualidade do ambiente militar como também pode ser o maior defeito, dependendo da forma como é utilizada. O grupo reforça que aqueles superiores na hierarquia militar devem, sim, estar comprometidos com o bom exemplo, em especial na forma de tratar os seus subordinados. Lucas destaca a importância do contato direto dos cadetes com a população. Afirma que aquilo que houve de negativo em termos de generalização sobre comunidades que seriam somente de bandidos e criminosos, a experiência de campo lhe mostrou que nessas comunidades existem pessoas de bem que merecem respeito e bom tratamento. Valoriza, portanto, essa aprendizagem que a prática, no contato direto com as pessoas, pode the ensinar, pois em termos do que ouvia teoricamente achava que todos eram bandidos. Ao fazer isto, critica a tendência da generalização exagerada e do maniqueísmo, assumindo um posicionamento que merece destaque dentre todos os entrevistados. André destaca a prática de humildade como o ponto que considera mais relevante na formação dos oficiais. Moisés fala entusiasmado dos valores de honestidade e sinceridade (falar a verdade) por parte dos militares, dando um exemplo em que um oficial descumpriu uma ordem do vice-governador para não mentir para o público. O grupo insiste em apreciar como existem oficiais superiores que tem humildade e respeito no trato com os subordinados, sem serem "frouxos". Moisés expressa que ficou surpreso com isto, pois fazia ideia de que todos seriam rígidos ("aquela seriedade extrema"). Davi chama atenção para uma prática que Ihe ajudou bastante a aprender a respeitar as pessoas, destacando como o respeito é importante para o ser humano e para a profissão. Fala também sobre a prática de rodízio de comando no CFO, que o ajuda a exercitar a prática do respeito, pois uma semana ele está no comando e, na semana seguinte, outro colega assume a função.

\section{Trecho 10 (linhas 728 a 737)}

"P: E do que vocês menos gostaram até agora na APM / formação?

E: Nossa! (risos de alguns cadetes).

M: É pra fazer uma lista?

P: Pode fazer...

E: Deixa que eu começo então! Brutalidade... O que eu acho pior dos piores é a pessoa achar que por ela estar num posto acima, ela não pode olhar na sua cara, ela não pode pegar na sua mão, ela acha que ela tem... Tipo assim, eu não sei porque coloca dentro de
\end{abstract}


um... de um... Ás vezes ligam isso ao... ao posto. Assim, se você é superior, você tem o direito de não cumprimentar, você tem o direito de não aceitar cumprimentos, de não olhar na cara dela... Isso pra mim é o pior que existe aqui dentro!

(...) (linhas 751 a 758)

L: Eu acho que as pessoas boas, os bons exemplos que a gente falou são minorias.

E: Eu não posso falar porque o que eu não conheço, o meu mundo é a academia! Então eu não posso falar.

M: Que por si só já é um ambiente chato!

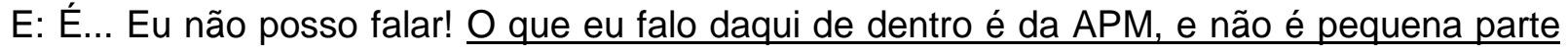
não!

M: É a maioria!

E: A maioria, é a grande parte!

(...) (linhas 797 a 798)

L: Isso é muito batido a gente falar, mas é o que Maquiavel fala, "dê poder a homem e o conhecerá!"

\section{(...) (linhas 804 a 815)}

"D: Não... Acho mais... Acho que também falta muita organização...

E: É, realmente!

D: As pessoas que estão de fora tem uma falsa sensação de organização!

E: Tudo é de última hora! Outra coisa também que me incomoda é a falta de foco! Por exemplo, eu percebo que a própria academia às vezes foca pra... pra... pra coisas que são desnecessárias! Vou dar um exemplo claro, todos os dias de manhã tem desfile aqui, e poderia ser usado isso de outra forma! A gente podia ter um dia de desfile pra manter as tradições e tudo e depois é... Os outros demais dias ir pra sala de aula. $\underline{O}$ foco aqui é a formação policial, e não a formação militar! Então eu imagino que é isso que tem que ser! 0 militarismo é uma estrutura, uma filosofia, tipo assim, é uma estrutura que vai formar a policia e que vai continuar mantendo ela, mas o foco aqui é a atividade policial."

(...) (linhas 819 a 821)

"A: Não... Eu concordo com a Ester na questão da... da... Acho que às vezes as pessoas confundem, confundem que o bom é ser grosseiro, é não olhar. Acham que essa questão da hierarquia, a questão do próprio posto tá acima de tudo!"

\section{Análise 10}

Esse trecho traz os posicionamentos individuais sobre o que menos estão gostando na APM / formação. As falas revelam pontos da cultura militar com os quais eles não concordam. Vale ressaltar como eles percebem as interações e relações interpessoais dentro do militarismo, 
considerando um de seus pilares: a hierarquia. O grupo considera que apenas uma minoria se comporta da forma que eles avaliam como correta na interação subordinados - superiores e elogiam essas pessoas. Nesse sentido, destacamos a célebre frase de Maquiavel replicada por Lucas: "Dê poder a homem e o conhecerá!". Os cadetes consideram que o poder ou o fato da pessoa estar em uma posição de poder modifica sua forma de tratar os outros, especialmente subordinados, e eles condenam essa prática. A questão da hierarquia é aqui entendida como algo a ser conquistado na base do mérito, e não do posto ou da antiguidade militar. São unânimes em criticar a ideia de que ter mais poder confere à pessoa o direito de ser grosseira com os subordinados. Isto é um problema complexo, porque na organização militar, mesmo que o oficial superior seja menos inteligente ou menos sábio que os seus subordinados, ainda assim a hierarquia precisa prevalecer. No entanto, esse formato de gestão desconsidera que a autoridade se alimenta da compreensão e do respeito humano e do reconhecimento das contribuições de todos.

\section{Trecho 11 (linhas 856 a 873)}

"D: Outra situação... Eu tive a oportunidade de trabalhar na cidade $\mathrm{X}$, na operação da Semana Santa. Foram apenas seis cadetes pra lá, e eu tive a oportunidade de ficar na praça central lá da cidade, onde o pessoal fica reunido, tem uns bares lá, muitos turistas... Enquanto os outros cadetes ficaram mais operacionais, fazendo bloqueio e etc. E eu pude observar o seguinte, a população, ela é muito... Alguns são próximos da policia, conversam com você, mas a grande maioria são muito distante! Eu percebi assim porque lá eu fazia ronda, olhava lá os postos, e eu queria olhar pras pessoas e falar um bom dia, um boa tarde, boa noite, ou dar um olhar, um semblante receptivo. Mas a grande maioria delas, quando me via assim, não me olhava, não me encaravam, não olhavam pra mim. Então isso, eu achei marcante do ponto de vista negativo. $E$ isso eu acho que a policia, ela tinha que trabalhar muito, MAS muito mesmo, com a proximidade junto a população. Pra quebrar essa questão histórica aí de... De... Que a policia é truculenta, que a polícia é violenta, que se eu olhar errado pra polícia, a polícia vai me abordar... Sabe? Acho que isso... isso foi muito ruim, porque... Eu queria às vezes uma receptividade, eu queria ser receptivo, mas as pessoas não me deram essa oportunidade. Não me olhava, não me encarava... A mesma coisa que você vê um inimigo seu vindo, você desvia o olhar, você viu a pessoa, mas finge que não viu." (...) (linhas 898 a 907)

"M: E o que eu menos gosto aqui é... Tanto na academia como formadora de oficiais, quanto na polícia, instituição polícia, quanto no militarismo, é o que eu menos gosto em todos eles... É a dificuldade de evolução! Que o militarismo enfrenta!_Aqui, é aquela questão da hierarquia ser a maior qualidade e o maior defeito. Isso aqui é uma instituição comandada por pessoas 
antigas. A gente até usa como é... Graduação de hierarquia, a palavra antiguidade né? "Fulano é mais antigo!" Não é necessariamente pela idade, nem pelo tempo que tá na polícia. Por exemplo, eu sou mais antigo que um sargento, que um subtenente... Sendo que eu entrei agora..."

\section{Análise 11}

Continuando a discussão a respeito do que menos gostam na APM / formação, Davi traz um exemplo de uma situação vivenciada por ele na qual ele afirma que a população é distante da $P M$. Faz uma crítica a essa situação, demonstrando uma emoção negativa ao relatar: "A mesma coisa que você vê um inimigo seu vindo, você desvia o olhar...". Esse relato demonstra que a atuação repressiva da PM tem sido mais significativa do que a preventiva, pois, no caso citado, as pessoas parecem ter "medo" do policial. Esse exemplo reforça a necessidade de mudanças de práticas, para que, em nossa avaliação, novas ações e atividades promotoras da Cultura de Paz possam modificar a imagem da PM junto à sociedade. Moisés, por sua vez, relata o que menos gosta na PM como um todo: "a dificuldade de evolução". Ele retoma a questão da hierarquia tecendo uma crítica à nomenclatura utilizada para designar classificação / subordinação: Antiguidade. Ele considera o termo como distorcido ou inadequado, pois não se relaciona à idade da pessoa ou ao tempo de serviço na instituição, mas ao posto que ocupa. Como eles já ingressam na instituição como cadetes, são mais "antigos" (ou superiores hierárquicos) que toda a classe de praças e isso causa muita estranheza. Essa parece uma questão difícil no processo de adaptação às normas institucionais, a hierarquia, como bem ponderou Ester no trecho 9, podendo ser algo positivo ou negativo, dependendo da forma como é vivenciado e exercido.

\section{Trecho 12 (linhas 1002 a 1015)}

"P: Nesse mesmo sentido, o que vocês consideram como mais importante na formação de oficial da PM?

E: Eu acho que principalmente a prática! A prática da atividade policial é o principal! A prática da atividade policial, mas prática da atividade policial mesmo! Trato com as pessoas, e também trato com os infratores da lei né? Das duas formas, tanto da sociedade em geral, quanto do infrator a lei. E menos militarismo, menos tradições... É importante tradição? É importante, mas assim, é nisso que eu vejo tanta diferença... Diferença assim, da sociedade lá fora pro mundo aqui dentro! Você entra aqui dentro e fala assim, meu Deus, mas que mundo é esse que esse povo tá vivendo? Isso não existe mais hoje em dia! Isso é uma coisa que não... Tem coisa que tem que ser tirado, que tem que ser excluído. Por exemplo, esse desfile aqui todos os dias, eu acho um absurdo! E o que me mostra que o foco aqui é o 
militarismo, a tradição. Não por questão assim, de não obedecer hierarquia, disciplina, mas por tradições às vezes até desnecessárias..."

\section{(...) (linhas 1027 a 1030)}

"E: Entendeu? Eu acho que a prioridade tem que ser a atividade policial!

A: A função policial, principalmente no mundo atual, ela é... principalmente pra nós aqui, ela tem que tá acima disso! Nesse trabalho de prevenção, de pressão, de saber lidar com a sociedade, é maior que o militarismo! Tem que ser maior!"

\section{Análise 12}

Esse trecho traz uma reflexão bastante interessante onde os participantes fazem uma distinção entre o militarismo e a atividade policial. Ester considera como o mais importante no CFO a "prática da atividade policial", mas acha que "o foco aqui é o militarismo, a tradição". Ela faz uma crítica à essa prática, postulando que isso faz a instituição ficar atrasada em relação à sociedade, no que tange às demandas na área de Segurança Pública. Considera excessivo o tempo gasto com os desfiles e acha que deveria ser aplicado no exercício da prática policial. André concorda com ela, e acha que o trabalho de prevenção da PM deveria ser maior que o militarismo. De uma forma geral, esse trecho resume as discussões anteriores, deixando claro que o grupo considera como prioridade a atividade policial e não o militarismo.

\section{Trecho 13 (linhas 1263 a 1282)}

"P: O que vocês pensam sobre esses rituais e solenidades militares que vocês têm conhecido e participado?

M: Vamos começar elogiando? Eu acho lindo! Principalmente pra quem tá assistindo de fora! Não, na verdade... É lindo, é lindo, é lindo! E... Assim, o civil... O civil, ele não é minucioso igual a gente é. Então foi igual foi nosso baile do Espadim aqui, o amigo que eu trouxe... NOSSA! Eu trouxe um amigo, convidei um amigo, do ensino médio pra ver...

$D: E$ a gente nem ensaiou muito...

M: Até hoje... Não, a gente fez na tora! A gente nem sabia que as viaturas operacionais iam desfilar! Mas o cara achou... Ele fala até hoje como se fosse a coisa mais bonita que ele já viu na vida! E ele falou assim: "CARA, a ROTAM, ela não passou normal não. Ela passava arrancando... E a cavalaria? O que foi aquilo? Foi perfeito..." Então assim, a gente viu aqueles errinhos. Teve gente que descansou no som da corneta... Não é... Eles acham... O pessoal que eu trouxe, até hoje falam que é uma das coisas mais fantásticas que já viram na vida! Então, de fato, é lindo! As solenidades são lindas e tem muita coisa interessante. Por exemplo, apresentação de turma, não é bacana esse negócio de apresentação de turma? $O$ 
professor vai entrar na sala, o pessoal levanta símbolo de respeito...

D: Eu acho bonito, sinal de respeito..."

\section{(...) (linhas 1292 a 1297)}

"M: Pois é, então tem esses rituais, mas também tem aqueles rituais que é o ritual da dispensa né? Em pé ali, ouvindo embuste, esse aí já é ridículo!

A: São muitas coisas... Quase todos os dias é a mesma conversa...

E: Quase todos os dias não. Que eu sei é todo dia os mesmos recados, os mesmos avisos!

A: É cansativo né? Pra gente... Porque você pensar, são dois anos isso?"

\section{Análise 13}

Sobre os rituais e solenidades militares observamos certa contradição. Ao mesmo tempo em que eles acham bonito, que os amigos elogiam e eles se emocionam com alguns deles, também se sentem aborrecidos, acham perda de tempo e cansativo. Vale ressaltar que essa repetição dos rituais e solenidade teria a função didática de conhecimento e assimilação das tradições militares, mas também de transmitir uniformidade, padronização e disciplina. Vale indagar, assim, até que ponto esta função didática produz apenas efeitos esperados.

\section{Trecho 14 (linhas 1455 a 1470)}

"A: E a palavra chave aqui é adestramento!

M: Nós somos adestrados a acostumar com o individual, com a tradição... Pra até... Até levar isso conosco.

$\mathrm{P}$ : E o que vocês sentem a respeito disso?

M: Infelizmente...

E: Eu sempre vejo assim, eu acho que tem coisas que é muito desnecessário, que pra mim oㅡ que brilha os meus olhos é liderança! Não é... Não é a pessoa estar acima. É o que vê, tipo assim, eu tenho que olhar pra pessoa q tenho que admirar...

A: Respeito...

E: É...

M: Exatamente! Respeito advém disso!

E: Não é porque ele tá superior que eu vou... Assim, tem coisa que não tem nem o que falar, mas assim, tem muita gente que eu olho, falo assim... "Meu Deus do céu, sabe nem conversar!"

A: É questão de admiração maior!"

\section{Análise 14}

Continuando na proposta discutida no trecho anterior, vemos aqui uma expressão muito 
utilizada nos cursos de formação militares: adestramento. Apesar de parecer pejorativo por ser um termo utilizado para animais, o significado dele se aplica à repetição dos processos comportamentais envolvidos, sobretudo, na prática da ordem unida. Interessante observar como eles percebem essa prática: "Nós somos adestrados a acostumar com o individual, com a tradição... Pra até... Até levar isso conosco". São ações carregadas de simbolismo, cuja redundância de mensagens sociais carregadas de conteúdos simbólicos busca promover uma efetiva internalização desse valor militar. Ester aqui sublinha a importância de aprender a liderar em contraposição ao simples adestramento.

\section{Trecho 15 (linhas 1612 a 1632)}

"P: Só pra gente encerrar então, eu queria que cada um falasse uma palavra ou uma frase, que represente seu sentimento de estar aqui na APM nesse momento da sua vida... De ter passado no concurso e agora estar aqui no Curso de Formação de Oficiais da PM.

E: $\underline{\text { Sacrifício! }}$

D: Olha, eu to realizado aqui dentro! Aqui na policia. Eu sei que vai ser pior, eu acho que... Que... Eu tinha certeza absoluta que ia ser muito pior do que é... Pelo menos aqui na APM. Tem essas questões que a gente pode melhorar ao longo da nossa carreira né? Que eu acho que as coisas não são... Não mudam da noite por dia, ainda mais numa instituição tradicional, igual é aqui na policia.

P: Uhum... Então a sua palavra seria realização?

D: Realização! E colaborar com a sociedade!

$\mathrm{L}$ : Me sinto orgulhoso de mim mesmo!

$P$ : Orgulhoso! E você Moisés?

M: É... Felicidade! Eu to feliz! Eu sonhava desde 2010 entrar aqui. É... Agradeço muito a Deus a oportunidade de tá aqui. Tenho certeza que muita coisa podia ser diferente, podia ser muito melhor. Mas no geral eu to muito feliz de estar aqui. Quero aprender bastante, é o que eu queria tá aqui. Tinha outras opções de ficar em outros lugares, de ficar onde eu estava (Polícia Civil) que também tava legal, mas eu queria vir pra cá e graças a Deus deu certo.

A: Palavra ou frase? Coloco numa frase. Espero que essa etapa passe logo! Tem coisa que se contradizem, tem coisa que a gente não concorda, passa por situações difíceis. Ao mesmo tempo, a gente passa por situações muito boas! A amizade que a gente cria aqui são coisas que eu to... Eu to aprendendo e crescendo muito!"

\section{Análise 15}

Nesse trecho final, podemos observar a diversidade de sentimentos suscitados e vivenciados a partir do ingresso no CFO. Após todas as discussões e posicionamentos aqui relatados e analisados, conseguimos perceber que as características e trajetórias individuais refletem 
diretamente na experiência inovadora que o curso está proporcionando a cada participante. Apesar de muitos consensos em relação às críticas à APM / formação, ou aos rituais e solenidades, vale destacar que os sentidos subjetivos atribuídos às experiências vivenciadas são ricos e estão contribuindo para a construção da identidade de Oficial da PM. Dos cinco participantes: três consideram-se 'realizado', 'feliz' e 'orgulhoso' de si; a participante considera o curso como sacrifício; e o último relata estar aprendendo e crescendo, mas gostaria que essa etapa passasse logo. No geral, as perspectivas atuais são boas e as expectativas para o futuro são melhores.

Apresentamos a seguir as análises construtivo-interpretativa das narrativas apresentadas pelos Tenentes nas entrevistas individuais semiestruturadas e no grupo focal.

\section{3 - ENTREVISTAS INDIVIDUAIS - TENENTES}

\subsection{1 - Análise Entrevista Tenente Gabriel}

\section{1 - Significado da carreira de Oficial da PM}

Trecho 1 (linhas 6 a 11)

"PESQUISADORA: Bom, eu queria que você começasse me contando um pouquinho, o que te motivou a entrar na carreira de oficial da polícia militar.

GABRIEL: É... O que me motivou foi o... Primeiramente, acho que a segurança, a estabilidade financeira e profissional né? E posteriormente também, a questão de valores mesmo e de razão de ser um policial, de status também... Acho que tá envolvido, então isso é um conjunto, financeiramente, profissionalmente e culturalmente também!"

Trecho 2 (linhas 19 a 36)

"P: E hoje, você gosta de fazer parte da Polícia Militar?

G: (longa pausa) É... Gosto!

P: Por quê?

G: Porque realmente é... É dela que eu... eu sobrevivo, que tenho... As coisas que eu consigo é através dela né? Meu salário, meu trabalho, minha profissão, que é valorizada e tudo! Mas acho que ainda poderia ser melhor, talvez... A instituição ou o meu trabalho. Eu falo assim, poderia ser melhor do meu ponto de vista profissional, melhorar em outras profissões, buscando outras áreas de trabalho.

$\mathrm{P}$ : Poderia me explicar melhor?

G: Depois que você cursa, que você vai realmente pra atividade que você vai ver, conhecer realmente o que é a profissão né? Eu não falo talvez, não pela instituição em si, mas em razão do material, do nosso instrumento de trabalho, de mexer com a criminalidade, talvez 
antes eu não entendesse direito... Não teria dimensão do que era isso.

$P: E$ isso te causa um pouco de reflexão?

G: Causa, causa um pouco de reflexão sim. Em vários momentos eu acho que... às vezes, te leva a pensar se você realmente escolheu a coisa certa né? $\mathrm{E}$ te faz até se motivar a procurar outras coisas. É claro que pensando que... A polícia, principalmente a Polícia Militar ela tem uma diversidade de... de funções."

\section{Trecho 3 (linhas 51 a 54)}

"G: Mas não que eu talvez... Não... Eu posso estar insatisfeito momentaneamente ou hoje, mas amanhã como capitão, eu posso estar em outra área que posso gostar...

P: Entendi! Por isso eu frisei bem o HOJE, como é que está hoje!

G: Hoje... Eu não estaria totalmente satisfeito!"

\section{Análise 1}

Aqui Gabriel é bastante sincero e indica que quando entrou para a PM não tinha ideia exata do que seria o seu trabalho. Sua motivação para o ingresso na época baseada em "segurança, a estabilidade financeira e profissional", ainda continua a mesma: "Porque realmente é... É dela que eu sobrevivo, que tenho... As coisas que consigo é através dela né? Meu salário, meu trabalho, minha profissão, que é valorizada e tudo!". Ele apresenta esperança de que no futuro ficará mais satisfeito, mas, no momento, apesar do status e valorização social da profissão, lidar com a "criminalidade" não lhe agrada.

\section{2 - Avaliação da PM}

\section{Trecho 1 (linhas 55 a 74)}

"P: E o que você considera, dentro do que você tem como satisfação, o que você considera ser o seu ponto forte aqui?

G: Talvez eu acho que...Um pouco questão de perfil, eu descobri o meu verdadeiro perfil... Às vezes que tava... Eu achava que eu tinha... eu era uma pessoa... talvez, operacional. Aí quando você se depara com a realidade, pensa 'não fui feito pra isso!' Até mesmo pela minha bagagem antes de entrar na polícia né? Tenho experiência em administrativo, sou formado em direito e tal... Então, talvez hoje, eu ainda não consiga me ver nessa posição! De fronte! Às vezes fico refletindo, num primeiro momento... Acho que não fui feito pra isso! Mas que também são... São situações novas que a gente é capaz de adaptar e conseguir desenvolver! Às vezes você não consegue dar o seu melhor, 100\%... Mas consegue desempenhar bem!

P: Mesmo não dando seu $100 \%$, o que você considera o seu ponto forte?

G: (respirou fundo) Bom, acho que principalmente estar na área que você se sente 
confortável, na área que você tenha estabilidade emocional... E eu acho equilíbrio, rotina, acho que isso... Não sei...

P: Então esse é o seu ponto forte? O local onde você está trabalhando? Não entendi bem...

G: Humm... Não!

$\mathrm{P}: \mathrm{O}$ que você considera como seu ponto forte, então?

G: Eu acho um local igual o rodoviário, que eu era do trânsito já... Ou talvez no ambiental, sei lá... Em outros... Em outros... Na parte mais administrativa mesmo! Acho que é o melhor. Corregedoria, talvez... Não hoje, nem nessa área operacional, na rua..."

\section{Trecho 2 (linhas 106 a 115)}

"P: Como você considera que a instituição Polícia Militar orienta seus policiais nessa questão?

G: A polícia ela tem orientado agir de forma correta mesmo! Agir dentro da legalidade, sempre... Com a rigidez que é peculiar, mas com... Dentro da legalidade, sem arbitrariedade... Mas a questão é: O policial anda numa linha muito tênue. Então essa é a situação, porque apesar da instituição trazer... Não só na instituição mas tudo o que a gente tá vivenciando, o país passando por um momento... é... Traz essa, esse direcionamento! Bom, mas em razão com essa linha muito tênue ali, você tá diretamente entre o certo o errado, entre conseguir prender o bandido ou não, e querendo ou não, você acaba cometendo algumas... algumas ações violentas que... pra conseguir determinados objetivos."

\section{Trecho 3 (linhas 194 a 218)}

"P: Você acha que a polícia, ela atua na prevenção da violência?

G: (pequena pausa) Ela atua...

P: Como?

G: Acho que a polícia... Vamos colocar na visão policial, sem falar das outras áreas. O que acontece? $\underline{O}$ papel da polícia é militar! Preventiva e ostensiva! Então esse é o papel dele, ostensividade e prevenção. Como que às vezes em determinadas áreas eu vou fazer uma prevenção com poucas viaturas? Duas... numa área gigante? Então ele não tá sabendo, mas a prevenção pela quantidade. A ostensividade passa pela quantidade! Se você conseguir aumentar o número de viaturas e policiais naquela localidade, o índice de criminalidade vai abaixar!

P: Entendi! Você acha que a presença física, concreta, visível da PM, é um fator de prevenção?

G: Ela é um fator de prevenção! Até porque a policia é... Ela é reconhecida através da sua viatura... Através da sua ostensividade... Da farda, da sua vestimenta... Então o que adianta se eu sou reconhecido por isso? É... Deveria fazer de forma que se torne realmente presente, visível! 
$\mathrm{P}$ : Ok. Tem algum outro programa na $\mathrm{PM}$, que você considere como preventivo da violência? G: Policiamento comunitário. Eu acho que realmente ele surte efeito! Porque ele consegue... traz o policial mais próximo do cidadão! Ele... ele acaba... porque o cidadão tem essa distância, uma barreira entre policial. E a partir do momento que você quebra essa barreira, que o policial passa a estar mais próximo do cidadão, ele se sente mais confortável, mais seguro..."

\section{Análise 2}

O que the ocorre em termos de prevenção da violência é a presença física e ostensiva da polícia, que assim inibe a criminalidade. Reclama da falta de mais policiais e viaturas para cumprir esta missão. Apenas quando é perguntado diretamente se conhece algum programa da PM que atua na prevenção à violência, ele cita a Polícia Comunitária. Mas sobre essa frente de atuação parece não ter muitas informações.

\section{3 - Violência: Conceito e Valor}

\section{Trecho 1 (linhas 77 a 89)}

"P: Então, falando sobre as práticas da Polícia Militar, você considera que as ações da PM envolvem violência?

G: Eu acho que desenvolve pela natureza da... da atividade! Ela em si envolve violência, $\underline{0}$ campo de trabalho dela é a violência! Então você lida com as demais situações, de uma briga de casal, até um assalto ao banco! Envolve violência, e você tem que ter às vezes... até sua forma de agir, deve ser diferente!

P: Você acha que poderia ser diferente? Que a PM poderia agir de uma forma que não transmitisse essa atividade violenta?

G: Eu acho que podia minimizar...

$\mathrm{P}$ : Como seria?

G: Através do... do próprio perfil da pessoa. Eu tiro por base assim... Eu sou uma pessoa, por mais de eu estar hoje num meio especializado, mas eu... eu sou uma pessoa muito tranquila, que gosta muito de conversar, de tratar bem as pessoas..."

\section{Trecho 2 (linhas 102 a 106)}

"P: Existe algum tipo de ação em que você considere a violência justificável?

G: Eu acho que se tratando de... de infratores mesmo... Infratores das mais altas... das mais... das infracões mais graves mesmo! E quando também, pra defender a sua vida e a de terceiros né? Essa é a maior..."

Trecho 3 (linhas 116 a 120)

"P: Afinal, o que você entende como violência? Como você define violência? 
G: Violência é o que causa é... um sentimento de dor, ou de é... momentânea... Vamos colocar psico... Tristeza psíquica da pessoa, né? Acho que isso caracteriza a violência física, causa dor, ou violência psíquica, que causa sentimentos de... desprezo, os demais sentimentos, tristeza, angústia, menosprezo... É... Como é que fala? Submissão! Tudo isso seria violência."

\section{Trecho 4 (linhas 123 a 135)}

"P: Quando você acha que uma pessoa precisa utilizar violência?

G: Uhumm. Não, justamente só precisa utilizar a violência no caso pra se defender... É... Defender terceiros ou se realmente aquela pessoa está ameaçando a sociedade.

P: Dá um exemplo pra ficar mais claro...

G: A pessoa que rouba um carro, que põe a arma na cabeça de um pai de família, de uma mãe de família, é... Essa pessoa já tem que ser tratada de uma forma diferente! E a partir do momento que ela ainda... Não só... Agride a policia, tem que ser respondida a altura!

P: O que você chama de "ser respondido à altura"? Por que eu sei que a policia tem um procedimento operacional padrão pra essas situações.

G: Respondido à altura é se... Vamos colocar, se ele efetua disparo contra a guarnição ela deve responder né? No intuito de fazer... Éééé... como garantia da sua integridade física!

$P$ : Então nesse caso a violência...

G: Ela é justificável... e necessária!"

\section{Trecho 5 (linhas 136 a 154)}

"P: Sabemos que é melhor prevenir do que reprimir. Mas você acha que é possível prevenir todo tipo de violência?

G: Não!

P: Por quê?

G: Porque a sociedade, ela é... ela... O cidadão ele tem os seus problemas individuais, existem os problemas individuais e coletivos, então não há como... Como se dizer? Entrar em cada residência e gerenciar todos os conflitos que ali existem, então isso é impossível! Então se a pessoa vai pra um bar, se divertir, e lá ele discute e resolve matar o outro, qual é o papel da polícia? Ele pode prevenir momentaneamente, ali se ele tiver presente. Mas se ele tiver com aquilo, ele vai pra casa, vai voltar e vai matar! Você não vai... Então nasce... É um problema às vezes cultural... Um problema que vai lá na raiz mesmo! Na raiz da família... Vai lá atrás! Então... na estrutura familiar... O Estado não vai conseguir por si só impedir a prática de crimes, ele vai conseguir reduzir, mas... Hoje, por exemplo, se a pessoa não tiver uma base moral, e valores, o que impede dele encostar sua moto no posto de combustível, falar pro cara abastecer e sair sem pagar? Tá cometendo um crime. Ou ele colocar a faca no cara e falar, me passa seu dinheiro! Não há... não tem condição de colocar um policial em 
cada posto de combustível! Isso vai do preceito dele moral, o que é certo e o que é errado. Aqueles que nascem... aqueles que nascem não. Aqueles que já tem essa percepção de que é certo e do que é errado, ou no meio, no convívio, que eles só vê coisa errada e acha que aquilo é natural, pra ele é um facilitador!"

\section{Análise 3}

Gabriel reconhece que a prática da polícia envolve violência e explica em que casos considera a violência justificável, de acordo com os preceitos da PM. Vale ressaltar, entretanto, que sua definição de violência é bastante simplista: "Violência é o que causa é... um sentimento de dor, ou de é... momentânea... Vamos colocar psico... Tristeza psíquica na pessoa né?" Na sequencia, sua definição acaba se reduzindo a "aquilo que causa sofrimento físico ou psíquico", sem maiores reflexões sobre a questão. Outro aspecto importante a ser destacado é a tendência em utilizar o termo "pai de família" ou "mãe de família", para se referir ao cidadão de bem, como se somente esse "cidadão de bem" merecesse proteção. Também vale salientar que seu primeiro impulso, ao explicar sobre pessoas com valores morais, foi "Isso vai do preceito moral dele, o que é certo e o que é errado. Aqueles que nascem... aqueles que não nascem não, aquele que já tem essa percepção do que é certo e do que é errado". Sua afirmação inicial, coloca a moral como algo genético ou que "vem de berço", mas logo em seguida ele corrige a afirmação. Sua narrativa demonstra, assim, que este tema a respeito do desenvolvimento dos valores, não tem sido objeto de reflexão.

\section{4 -Paz: Conceito e Valor}

\section{Trecho 1 (linhas 293 a 311)}

"P: Atualmente, ouvimos muito falar da questão de paz. Como você conceituaria paz? O que você define como paz?

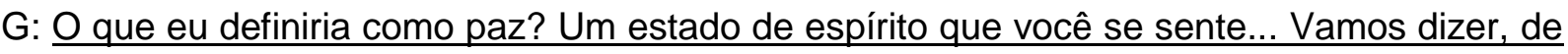
bem, bem com você, bem a onde você vive, bem com a sociedade... Espírito de paz, né?

P: Você acha que no mundo de hoje é possível construir essa paz?

G: Acho que não...

$P$ : Por quê?

G: Acho que não... Ah... A gente vive a todo momento sendo... Na verdade a gente busca a paz né? Acho que essa é a nossa finalidade, buscar a paz. Mas acho que não é possível porque não depende só de mim, aí é que tá! A paz não depende só de mim, depende de outras pessoas, e aí é o que acontece!

$\mathrm{P}$ : No que depende do outro, você acha que não é possível construir a paz?

G: Não, não é... 
P: Se dependesse de uma pessoa individualmente, seria possível?

G: Seria possível! Por que não depende do outro? Por que ás vez to bem comigo, to bem com a minha família, na minha casa, tudo... Mas a partir do momento que você sai na rua, você já perde a sua tranquilidade, aquilo que chamo de paz, o seu estado de espírito de... Tranquilidade, de calma... Porque você ali tá sujeito a qualquer coisa! Aí já... Por isso que eu falo que não depende de mim, que aí já depende de outros... Outros fatores!"

\section{Trecho 2 (linhas 317 a 331)}

"P: Você acha que a Polícia Militar hoje, promove essa construção da paz?

G: Ela busca isso! Ela tem buscado.

P: Como?

G: Buscado na luta diária, assim... Trazer a tranquilidade para o cidadão. Aquele cidadão... Acho que eu vejo assim, eu tenho aquela visão de que enquanto as pessoas estão ali no seu momento, na sua vida, na sua casa, a polícia militar está do lado de fora tentando... Fazer com que ela se sinta tranquila! Que as coisas mantenham a ordem né? E ela tem buscado isso, apesar da dificuldade!

$\mathrm{P}: \mathrm{O}$ que você considera como maior dificuldade?

G: Dificuldade é justamente você... A desmotivação, às vezes... A desmotivação em todos os sentidos, profissional... É estatal né? As coisas não andam como a gente queria... Em termo de... (pequena pausa) De... de Estado mesmo! Acho que o que desmotiva é você fazer... Conseguir às vezes pegar o individuo em flagrante, com quatro, cinco passagens, e você vê que ele ainda tá na rua... É um serviço que você faz de enxugar gelo! É enxugar gelo! É muito complicado! Eu vejo assim, depois que você entra aqui que você vai valorizando os policiais."

\section{Análise 4}

Gabriel traz um conceito simplista de paz, também muito utilizado pelo senso comum " $\underline{U m}$ estado de espírito que você se sente... Vamos dizer, de bem, bem com você, bem a onde você vive, bem com a sociedade..." Conceitos semelhantes foram observados em estudo anterior (Moreira, 2011), o que acaba sendo preocupante quando se trata de profissionais que lidam diariamente com a paz social e ordem pública. Um aspecto relevante a ser destacado no trecho 2, quando ele se refere ao trabalho da PM: "É um serviço que você faz de enxugar gelo! É enxugar gelo!" Essa tem sido uma fala recorrente entre os policiais em geral e os participantes da pesquisa, especificamente, demonstrando grande insatisfação com a legislação vigente. Eles sentem que seu trabalho não tem frutos consistentes, pois acabam efetuando a prisão da mesma pessoa repetidas vezes. Ou seja, a efetividade de seu trabalho não é algo concreto para eles 


\section{5 - Formação do Oficial na PM}

Trecho 1 (linhas 274 a 289)

"P: No curso de oficiais, é... Em que situações ou disciplina, treinamento, esse tema violência foi abordado com vocês?

G: Teve... teve sim, Diretos Humanos. Mas acho que a instituição, ela... No meu ponto de vista, ela não peca na parte que lhe é... Cabível, que é a sua responsabilidade. Que é a de orientação do policial, de como agir correto, de como deve ser feito, é... Prazos, legislações e tudo. Mas acho que ela é bem... O policial acaba sendo bem instruído de como deve agir. É claro que as coisas na rua são muito dinâmicas, a coisa toma proporção muito grande, muito rápido e às vezes nem sai da forma que você espera...

P: Mas então, em sua opinião, o curso de formação ele contempla essa temática de forma satisfatória?

G: Contempla... contempla sim!

P: Você se considera, saindo do curso de formação de oficiais...

G: Sabendo tudo! Percepção do que é certo, do que é errado, o que você deve fazer, a forma de como você agir... A disciplina de Direitos Humanos, o próprio Policiamento Ostensivo Geral, que a gente aprende a abordar e tudo... Isso tudo é passado! Foi tudo elaborado com base na doutrina de respeito das garantias e liberdades individuais!"

\section{Trecho 2 (linhas 334 a 347)}

"P: Falando agora do CFO, você acha que de alguma forma ele promove a construção da Cultura de Paz?

G: Eu acho que não! É... Eu acho que do ponto de vista... do ponto de vista policial, sim. Acho que eles acham que estão preparados pra promover a paz. Mas acho que... A própria... Aí entra nessas questões de academia que interfere na vida, na promoção da paz...

P: Por quê? Você pode ser um pouco mais claro?

G: (risinho) Na verdade é... Tem a rigidez do militarismo, por algumas coisas que... que praticam às vezes, até desnecessárias, assim... A própria rotina da academia dificulta...

P: Você acha que não promove a Cultura de Paz?

G: Não! Não promove cooperação. Promove a competição, certeza! E acaba nesse ponto trazendo a animosidade, rivalidade né? Eu tenho colegas tenentes igual a mim, que são de outra turma que não nos damos bem. Justamente porque foi no âmbito... enquanto na academia, é... Não souberam trabalhar essa forma, e depois, quando saiu, essa animosidade continuou né? Continuou as lembranças do que aconteceu, tudo..."

\section{Análise 7}

Nesse trecho vimos uma grande contradição entre o relato do que a APM proporciona 
enquanto formação e o que acontece na prática. Ele diz que o tema da violência é muito bem abordado durante o curso e ele considera que "sabe tudo" sobre a temática. Mas, segundo ele, o CFO não promove uma cultura de paz e não pratica a cooperação. Afirma que o que acaba ocorrendo é a promoção de uma animosidade e rivalidade entre os cadetes, a qual pode se estender para além da APM. Gabriel não consegue fazer uma reflexão de como a competição, hostilidade e rivalidade podem conduzir à violência, daí a contradição vista em sua fala: o curso prepara para a ação adequada e respeitosa dos direitos humanos (segundo ele), mas na prática promove a competição, inimiga da paz. Quanto a promover a Cultura de Paz na sociedade, tudo indica que esta nem é cogitada, o que acaba sugerindo que ele realmente não teve a oportunidade de discutir as relações entre violência, hostilidade, paz, e o respeito entre as pessoas.

\section{6 - Prática Policial}

\section{Trecho 1 (linhas 247 a 263)}

"P: Você já teve que utilizar alguma prática violenta? Como foi?

G: (pequena pausa) Já... Talvez por... por... Em se tratando de elemento de alta periculosidade né? Ou até mesmo em busca da credibilidade da própria instituição, do seu nome, dos próprios policiais né? Às vezes aquele respeito... Vamos colocar, não o cidadão de bem, porque eu acho que o cidadão de bem ainda tem respeito pela policia, mas a marginalidade, não sei também dizer o por quê, talvez pelas frouxas leis, por ele saber que não dá nada, a policia vai perdendo credibilidade, aí ele acha que pode zoar o policial! Pode... entendeu? Aí você tem que agir de uma forma mais enérgica pra conter aquela situação, ou até mesmo pra evitar o prolongamento de outras... Numa briga, você tem que agir de forma mais enérgica e tal... Mas violência, violência mesmo, aquela física... nunca pratiquei não!

P: E a psicológica?

G: A psicológica sim! Na forma de você falar mais enérgico e tal... Pressionar! Dessa forma...sim. Porque até mesmo... Se for pensar por outro lado, se o policial for, como autoridade e agente da lei, for... For muito bonzinho... Ele não vai... Não conseguir o que ele quer. Não vai conseguir abordar uma pessoa né? Colocar a mão na cabeça, fazer uma busca pessoal... Porque a expressão corporal, a linguagem não verbal, ela conta também né? $\mathrm{Na}$ atividade policial, sua firmeza conta muito... Então é isso! Você falar de forma mais ríspida..."

\section{Trecho 2 (linhas 268 a 273)}

"P: E se precisar utilizar arma de fogo?

G: Arma de fogo, sim! Vou utilizar, até mesmo porque eu venho percebendo que raras às 
vezes $0 . .$. O indivíduo lá, o... O infrator da lei ele obedece... Em situação de flagrante ele obedece a policia... É muito raro! Ele tenta evadir, ele tenta afrontar, entendeu? Então nesse ponto de vista, em nome da própria defesa da... Da sociedade, tem que agir, tem que utilizar do que for preciso pra conter aquilo lá e... Conseguir a detenção."

\section{Análise 6}

Aqui parece haver uma contradição entre o conceito que ele traz de violência e o que considera como prática de violência. Se por um lado, ele afirma que há violência quando há dor física ou psíquica, nesse trecho considera que a "firmeza" e a "rispidez" são formas de violência necessárias para se impor perante os "marginais". Parece utilizar dessa forma de procedimento para fazer valer sua autoridade policial, como bem afirma "Na atividade policial, sua firmeza conta muito... Então é isso! Você falar de forma mais ríspida..."

\section{7 - Conflito e suas funções}

Trecho 1 (linhas 350 a 365)

"P: Vamos falar sobre o conflito. Em sua opinião, o que seria o conflito?

G: Conflito é uma divergência de opinião, de ideia, de objetivo... Eu quero uma coisa e você outra, já tem um conflito...

P: Você acha que o conflito pode ser positivo?

G: Pode! Não vejo todo conflito como sendo negativo não. Em termos de sociedade... Acho que todo conflito... Mas existem conflitos saudáveis, não? Entre uma divergência de interesses, mas que você possa saber lidar com isso. A forma de chegar... Existe um conflito, um exemplo, se eu quero um celular e você também quer, há um conflito de interesse, mas nem por isso nós precisamos brigar pelo celular. Nós podemos às vezes, conversar e chegar na melhor... Então por isso que eu falo, o conflito... A possibilidade de ter o conflito e ser assim...

P: Você tem outro exemplo? De conflito positivo...

G: (pequena pausa) Ai... (pequena pausa) Eu acho que... Um conflito, por exemplo, por melhorias no bairro... No bairro que a pessoa mora... Às vezes, cobrando o asfalto ou a água tratada... Há conflito, mas pode ser positivo, pode sentar e conversar com o prefeito, ou quem quer que seja, pra providencia seja tomada e assim resolver o problema! Ou se não tiver condição de fazer, que eles cheguem na melhor... Da melhor forma possível, na solução melhor!"

\section{Análise 7}

Gabriel vê o conflito como podendo ser positivo pelo simples fato dele não evoluir para uma 
briga. Porém, somente quando indagado sobre exemplos de conflito positivo é que parece pensar sobre o assunto., e as pausas indicam que nunca fez uma reflexão profunda sobre o assunto. Conclui com um exemplo interessante onde o conflito foi criado para buscar melhorias sociais, destacando a importância da negociação.

\section{8 - Análise das imagens}

Imagem 1 - Civil chutando o rosto de um policial militar (linhas 468-473):

"P: O que você sente quando você vê essa imagem?

G: Quando eu vejo uma imagem dessa eu sinto uma afronta ao Estado! A afronta não é pra esse policial, é ao Estado, a sociedade. O policial tá representando a sociedade. Então eu acho assim, a que ponto que chegou o cidadão né? De se atentar contra um policial militar dessa forma... Representante do Estado. Então não é contra ele fisicamente só, é uma afronta contra toda a sociedade, no geral né?"

Imagem 2 - Policiais militares agredindo um civil (linhas 475-481

"G: Isso aí é... é... uma... Consequência do que a própria sociedade, legislação e justiça faz né? Por que às vezes o policial... Dependendo da situação que... Não dá nada, ou as leis são muito brandas... Gera esse tipo de frustração no policial que ele descarrega na agressão, na própria agressão. O que não justifica, lógico!

$P$ : Mas o que você sente quando você vê uma imagem dessa?

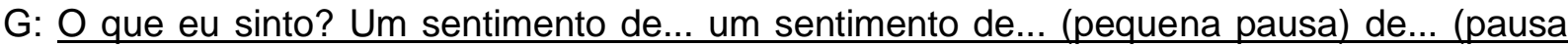
média) de... (estralo de dedo) de surpresa! Em ver esse despreparo todo por parte dos policiais."

Imagem 3 - Coronel da PM agredido em uma manifestação (linhas 483-488)

"G: É... (pausa média) De indignação. Um policial, só que... Parece... Ele foi agredido por civis também né?

P: Sim

G: Então é... Justamente, a gente fica indignado por conta de se tratar dessa maneira um policial que está no seu horário de serviço né? E que não tem o devido respeito da própria sociedade, dos infratores."

Imagem 4 - Policiais fazendo contenção de um civil em manifestação (linhas 490-494)

"G: Eu vejo como... Há necessidade... Esse cidadão aí às vezes está sendo imobilizado dessa forma porque eu tenho certeza que ele cometeu alguma infração para que gerasse essa... chegasse nesse ponto! De que a policia precisasse utilizar a força... Se necessário for. E se for necessário fazer uma imobilização, uma detenção mais agressiva, é lógico que você tem que fazer! Se ele tiver resistindo, você vai ter que conter ele e fazer a detenção. Acho que é a necessidade..." 


\section{Análise 8}

O sentimento de indignação e revolta é explícito nas imagens que mostram o policial sendo agredido, em especial diante da Imagem 1. No entanto, na imagem 2, ele demonstra dificuldade em nomear o sentimento e justifica a ação policial" Dependendo da situação que... Não dá nada, ou as leis são muito brandas... Gera esse tipo de frustração no policial que ele descarrega na agressão, na própria agressão." Mesmo que no final deixe claro que "não justifica", relata ficar apenas "surpreso" com a imagem. Na imagem 4, considera que houve "necessidade", que trata-se de uma abordagem de contenção normal da PM. Interessante observar os níveis de sentimentos envolvidos em cada imagem: de revolta e indignação, passa para surpresa e termina em indiferença.

\section{9 - Análise do vídeo}

\section{Trecho 1 (linhas 495 a 528)}

"P: Qual o sentimento quando você vê um vídeo como esse?

G: De indignação! Indignação! Assim, a sociedade maltratando quem não tem nada a ver com o problema! A Polícia Militar não tem nada a ver com o problema. E tá sendo agredida por manifestantes e tal. O que a Polícia Militar tem que fazer? Manifesta, grita, mas a Polícia Militar tá ali fazendo o seu papel né? Tá na sua função né? E inclusive foram agredidos, foram passivos. Tiveram que ter muita calma né? Então assim, é indignação! Eu fico indignado como a sociedade trata quem cuida dela né? A Polícia Militar é paga pra cuidar da proteção do cidadão e ele atenta contra ela... Então assim... Mas isso acontece nos países onde a política é fraca! A política da segurança pública é fraca! Por que a Polícia Militar não encontra respaldo dentro da própria sociedade né? Por que eu vejo assim, num país desenvolvido, quem é que vai levantar a mão pra um policial né? Que tá ali pra proteger, pra servir... Quem vai confrontar? Não estou dizendo que eu sou contra o manifesto... Protesta! Vai pra lá! Mas o que a Polícia Militar tem a ver com isso? Por que você vai agredir a policia militar?

$\mathrm{P}: \mathrm{O}$ que você sente quando vê seus colegas sendo xingados?

G: A gente fica chateado né? Fica triste por ver colegas policiais, colegas de farda, passando por uma situação dessa sem poder fazer nada né? Isso que é o pior... É você ser agredido, ser atentado e não poder fazer nada! Nós estamos numa total inversão de valores né? Qualquer foto, daquelas anteriores, que mostra o policial algemando, é porque realmente era situação pra isso! Por que se você afronta, se você agride, a policia deveria ter o respaldo pra também reagir com truculência, pra pegar, pra realmente prender e exercer a força necessária na medida... Na medida da agressão.

P: Entendi! Então, se você tivesse no meio dessa manifestação aqui, como é que você acha 
que estaria se sentindo?

G: Igual estou agora! Indignado, porém, é... Previsto, previsto.

$\mathrm{P}$ : Como assim?

G: Contido e... Assim, indignado com a situação, contido e... Porque isso daí é de se esperar né? Da sociedade. A gente já pode... Quando você tá numa situação dessa você já tá esperando isso. Você não espera uma outra ação da população que não seja essa! Porque a... A cultura, principalmente dessas pessoas de esquerda é de martirizar a policia. É de afrontar a policia. Como se... Devido acho que... Devido a ditadura, devido ao passado, pelas ações que ela fez! Então assim, o que elas tem ali? Eles veem o policial como representante do Estado, então aí ele deve pagar o pato por tudo que tá acontecendo. 'Vamos descarregar $\underline{\text { nele, }}$ porque ele que vai escutar agora'. É o que está sendo representado aqui, então tem que ouvir! Acho que funciona... Mais ou menos assim."

\section{Análise 9}

Alguns pontos demandam reflexão. O sentimento "De indignação! Indignação! Assim, a sociedade maltratando quem não tem nada a ver com o problema!" sugere uma identificação com os policiais que ali estavam e uma exclusão da participação da PM no contexto da manifestação. Se a PM foi chamada para garantir a preservação da ordem e do patrimônio público naquele local, ela tem algo a ver com o que está acontecendo. O que não significa dizer, que mereçam ser xingados ou desrespeitados. Outro ponto a considera é a fala "a policia deveria ter o respaldo pra também reagir com truculência, pra pegar, pra realmente prender e exercer a força necessária na medida... Na medida da agressão...". Essa fala reflete um posicionamento construído segundo a Lei de Talião "dente por dente, olho por olho". A cada ação violenta contra a PM ela deveria responder também com violência. É um posicionamento perigoso, para quem está na posição de agente promotor de ordem e paz social! "A cultura, principalmente dessas pessoas de esquerda é de martirizar a policia". Aqui temos uma dupla generalização. Por um lado, um pensamento de que todos os presentes na manifestão são de esquerda. E por outro, de que todos de esquerda martirizam a PM. Apenas ao final, ele consegue fazer uma análise mais ampla da situação, considerando a possível e provável reação das pessoas que xingam a $P M$, pois anteriormente parece acreditar que não havia razão de ser.

\section{0 - Sugestões e ideias para a PM promover a Cultura da Paz}

Trecho 1 (linhas 369 a 380)

"P: Pra finalizar e lembrando que nossa pesquisa é sigilosa, você acha que a Polícia Militar hoje, ela poderia promover mais a Cultura de Paz? Você teria alguma sugestão? Alguma 
ideia nesse sentido?

G: Ela tem condição, só que seria muito difícil! Justamente pela doutrina e pela hierarquia né?

P: Teria alguma ação prática que ela poderia desenvolver na sua opinião, para promover a paz? Você tem alguma sugestão?

G: Acho que atividade em grupo, acho que palestra sobre como lidar com o próximo, sem... Sem ferir a intimidade dele, sem agredir... Uma forma que você possa conversar, ou até dar ordens e procurar saber... Acho que o maior dos problemas é as pessoas não saberem respeitar a... Não saberem discernir o que é hierarquia de amizade, do próximo, do companheirismo... As coisas se misturam!"

\section{Trecho 2 (linhas 398-408)}

"P: Mais alguma sugestão ou reflexão?

G: Eu acho que... Eu acho que... Eu costumo dizer assim, que o país... Assim, de uma forma geral, precisa passar por uma transformação profunda mesmo! Assim, você saber que o cara vai ser preso e que não vai acontecer nada, ou às vezes... Isso, isso gera outros... Outros... Transtornos. Veja bem, se um policial sabe que se pegar aquele ladrão e ele não vai... Amanhã vai encontrar com ele na rua, e ele é um cara perigoso, o que você acha que... $\underline{0}$ incentivo dele querer tirar a vida daquela pessoa ali é bem maior! Então a partir do momento que o Estado, ele se tornar mais presente e a justiça ser mais efetiva, as coisas vão começar a dar certo. Então, se eu prender alguém por tráfico de droga, deu certo, ele vai pra cadeia. As pessoas começam a ver que as coisas funcionam, isso vai melhorando... Melhorando como um todo!"

\section{Análise 10}

Nessa última parte, ele ainda continua a ver a Cultura de Paz como algo interno, que dependeria dos valores pessoais e das interrelações construídas no local de trabalho. Acha difícil a PM construri a paz devido à "doutrina e à hierarquia". Mesmo assim, sugere "palestra sobre como lidar com o próximo"; "Uma forma que você possa conversar, ou até dar ordens e procurar saber..."

Ao final, traz uma sugestão coerente com suas reflexões anteriores: leis mais eficazes evitariam a violência policial, isto é, ele diz que "Então a partir do momento que o Estado, ele se tornar mais presente e a justiça ser mais efetiva, as coisas vão começar a dar certo". É uma sugestão / reflexão bastante pertinente, uma vez que o devido funcionamento do sistema judicial daria mais respaldo ao trabalho da PM e diminuiria a tentação dos policiais fazerem "justiça com as próprias mãos". 


\subsection{2 - Análise Entrevista Tenente Suzana}

\section{1 - Significado da carreira de Oficial da PM}

Trecho 1 (linhas 7 a 18)

"PESQUISADORA: Bom, para começar nossa entrevista eu gostaria de saber o que te motivou a entrar na carreira de oficial da Polícia Militar?

SUZANA: Desde pequena eu sempre tive admiração pela Policia Militar, pelo fato que minha tia, ela foi uma das primeiras turmas de praça que teve da polícia, se não me engano a segunda turma em 86. Então ela me levava pra assistir os desfiles na APM, levava pra assistir o desfile de 7 de setembro. Então eu criei gosto a partir dessas datas aí, na minha infância. Quando tive a idade da adolescência, entrei no Colégio Militar... Aprimorou mais ainda o meu desejo de entrar pra corporação. Só que quando eu estava me formando no $3^{\circ}$ ano, eles exigiram formação em Direito pra entrar no oficialato, até então era só Ensino Médio. Aí eu fui fazer o curso de Direito, quando terminei prestei o concurso. Só que eu não fui chamada na $1^{\text {a }}$ turma de CFO, e quando me chamaram na turma excedente, eu entrei e conclui o curso."

\section{Análise 1}

Diferentemente do participante anterior, Suzana relata uma "vocação" como motivo maior de seu ingresso na carreira da PM. Foi uma admiração que surgiu na infância e foi alimentada durante toda sua trajetória de vida. Destaca-se aqui, que apenas essa motivação foi citada e o fato da tia ser militar é um fator a ser considerado, já que é comum vermos muitos membros da mesma família nas corporações militares.

\section{2 - Avaliação da PM}

\section{Trecho 1 (linhas 23 a 29)}

"P: E hoje, você gosta de fazer parte da Polícia Militar?

S: Gosto, tenho orgulho!

P: Por quê?

S: Porque eu sempre quis ser policial, e eu acho que me identifico muito com a Policia Militar! Na questão de organização, na distribuição de funções, acho que é um lugar assim, que a gente consegue desenvolver mais os objetivos, pelo fato mais da organização também!"

\section{Trecho 2 (linhas 33 a 43)}

"P: Então o que você vivencia hoje na PM, era o que você sonhava desde criança?

S: Em tese sim!

$\mathrm{P}$ : Por que em tese?

S: Por que... Quando a gente está no mundo civil, a gente tem uma falsa ilusão de que a 
Polícia Militar é perfeita né? Que realmente a sociedade vai enxergar a gente com olhos de defensores mesmo e que realmente a gente vai ter a proteção devida! E quando a gente entra, a gente vê que não é bem assim... Tem muita deficiência, muita carência, tanto de recursos materiais como humanos. Às vezes o entendimento daqueles que estão no comando não é o entendimento da maioria, por exemplo, que estão na subordinação..."

\section{Trecho 3 (linhas 53 a 71)}

"P: O que você considera como sendo o seu ponto forte no trabalho da PM?

S: Meu ponto forte acredito que seja a perseverança, insistência, pra alcançar algo que realmente traga benefícios! Pra não ser mais um que veio somente usufruir da... Da patente né? Ou do posto! Que realmente possa deixar um legado, mesmo que ás vezes sejam penas duras né?

$\mathrm{P}: \mathrm{O}$ que você chama de duras penas?

S: Duras penas seria a retaliação... Seria o preconceito, eu... Ás vezes até mesmo o machismo né? Que ainda impera... Por ser mulher, acaba que sofre um peso maior, pra expor ideias, pra apresentar projetos. Nesse sentido é mais complicado.

P: Você sente algum preconceito em relação a esse fato?

S: De certa forma sim, por mais que ás vezes a pessoa te respeite, ás vezes até mesmo pelo posto, mas acaba sentindo que é só mesmo questão profissional, o respeito ali é em tese... Que ás vezes se não fosse superior a essa pessoa, ela te ignoraria totalmente!

$\mathrm{P}:$ Como você se sente a respeito disso?

S: Me sinto... Ás vezes num primeiro momento, até penso assim: 'nossa que situação chata'. Mas isso aí não me influencia e não interfere no meu modo de agir, de pensar não! Nem me desestimula a correr atrás daquilo que eu tenho como meta!"

\section{Análise 2}

Esse trecho reforça a identificação e o orgulho que Suzana sente ao se ver como integrante da PM. No entanto, esses sentimentos não alteram sua visão crítica a respeito da instituição, conseguindo identificar as fragilidades existentes: "a gente tem uma falsa ilusão de que a Polícia Militar é perfeita né? (...). E quando a gente entra, a gente vê que não é bem assim...". Outro ponto a ser destacado nesse trecho é a questão de gênero. Sua fala deixa explícita a presença de preconceito por ser mulher e também por ser oficial e exercer função de comando. No entanto, demonstra lidar bem com a situação e não deixar que seu aborrecimento por ser discriminada influencie suas metas na instituição. Vale ressaltar, que ela faz parte de um grupo especializado, cujo ambiente é quase que totalmente ocupado pelo universo masculino, e aspectos como força e coragem são testadas e cobrados a cada instante. 


\section{3 - Violência: Conceito e Valor}

\section{Trecho 1 (linhas 74 a 82)}

P: "Ok... Agora vamos falar um pouquinho sobre a violência. Se você tivesse que definir pra alguém o que é violência, como você definiria?

S: Definir violência? Acho que seria algo que ferisse a intimidade ou até mesmo os valores que certa pessoa carrega consigo.

P: Dá um exemplo...

S: Que a violência é uma coisa ampla, ela pode ser tanto física... pode ser psicológica, ás vezes, por exemplo, o que é importante pra uma pessoa, não é importante pra outra, ou ás vezes uma ação pra aquela pessoa $X$, pode ser considerado um ato de violência porque feriu os objetivos dela. E pra uma pessoa Y já não seja..."

\section{Trecho 2 (linhas 86 a 91)}

"P: Você acha que as ações práticas da PM envolvem violência?

S: De certa forma, sim

P: Em que casos você acha que as ações violentas da PM se justificam?

S: Essa ação sempre vai ser justificada a partir do momento em que o bem que ela está tentando preservar ou restabelecer, seja maior... Do que as próprias ações."

\section{Trecho 3 (linhas 133 a 146)}

"P: Você acha que uma pessoa precisa utilizar de violência?

S: (pequena pausa) A sociedade tem levado a esse pensamento que... Eles pesam o seguinte: como a Polícia Militar não é capaz de resolver os problemas que surgem, então seria interessante cada um se auto municiar para se proteger. Por exemplo, a pessoa ter porte de arma. Porque nem sempre a viatura, nem sempre o policial vai estar ali na hora do crime! Principalmente os comerciantes, tem essa ideia... E, muitos deles, fazem isso sem a gente ter esse controle!

P: Uhum... Mas você acha que é preciso? Eles precisam utilizar de meios violentos, mesmo que seja pra se proteger?

S: (pequena pausa) eu não sei se precisa, se... Se realmente é necessário. Só que é complicado a gente entrar nessa seara porque é questão de sobrevivência do próprio ser humano, desde sua criação, é se auto defender. Reagir, criar forças, mesmo que ele não tenha no momento, pra defender sua vida ou até mesmo uma pessoa que ele goste, de um terceiro..."

\section{Trecho 4 (linhas 179 a 185)}

"P: Sabemos que é melhor prevenir do que reprimir. Gostaria de saber: você acha que é possível prevenir todo o tipo de violência?

S: Não... (pequena pausa) Tudo é muito relativo! A gente pode minimizar às vezes os 
problemas, mas prevenir não. Até mesmo porque, a maioria... Alguns dos criminosos, a maioria deles, tem transtornos psicológicos mentais. E não tem como prevenir isso! Acho que não tem como. A não ser que fosse a própria família, uma estrutura familiar melhor, ai já passaria dos limites da própria policia."

Trecho 5 (linhas 219 a 231)

"P: Existe algum programa ou projeto na PM que você considera que atua na prevenção da violência?

S: $\underline{\text { O mais importante acho, que tenho visto é PROERD. Porque como eu disse, o meu gosto }}$ pela policia surgiu na minha infância, eu tinha uns dois, três aninhos de idade, eu ia assistir o desfile... Apesar... Não é uma premissa de 100\%... Porque eu poderia ter me desviado pra outra coisa, pra outras áreas, ou até mesmo para o crime né? Só que eu acho que é uma prevenção... E de certa forma, traz bons resultados! Aquele acompanhamento que a policia faz ali daquela população carente, daquelas crianças... Eu acredito que os resultados ali tem sidos bem positivos!

P: Uumm...

S: Porque a criança se sente importante, valorizada e instiga nela aquele desejo "Nossa eu posso também ser policial" ou "Eu aprendi alguns preceitos que vão me ajudar a realizar tal sonho!"'"

\section{Análise 3}

Ela traz um conceito muito vago e subjetivo de violência, no qual uma ação para ser considerada violenta dependeria de como a pessoa se sente em relação a ela. Segundo Suzana, passaria por um crivo individual. Tal conceito acaba sendo preocupante, por advir de um agente de segurança pública. Ela assume que as práticas da PM, de certa forma, envolvem violência, mas considera: "Essa ação sempre vai ser justificada a partir do momento em que o bem que ela está tentando preservar ou restabelecer, seja maior... Do que as próprias ações". Tal argumento passaria, assim, pela subjetividade do policial que vai exercer a ação, uma vez que ele teria que fazer esse julgamento do que considera como "bem maior", em cada ocorrência que atender. Em síntese, não haveria uma orientação geral no sentido de evitar-se a fácil recorrência à violência por parte do policial. A respeito da prevenção da violência, temos uma explicação surpreendente "Alguns dos criminosos, a maioria deles, tem transtornos psicológicos mentais. E não tem como prevenir isso!". Uma justificativa reducionista, pois ela exclui vários fatores que contribuem para que a pessoa se torne um criminoso, e generaliza, demonstrando desconhecimento do que significa "ter um transtorno psicológico mental"! Segundo ela, podemos inferir que a polícia nada pode fazer para reduzir a violência, pois a responsabilidade é toda da família dos criminosos com 
problemas mentais. Quando perguntada diretamente, porém, ela cita o PROERD como um programa eficaz na prevenção da violência e faz uma reflexão interessante a respeito: "(...) o meu gosto pela policia surgiu na minha infância (...). Não é uma premissa de $100 \%$... Porque eu poderia ter me desviado pra outra coisa, pra outras áreas, ou até mesmo para o crime né? Só que eu acho que é uma prevencão... E de certa forma, traz bons resultados!". Ao mesmo tempo em que sugere a influência exercida sobre ela desde a infância como fator delineador para seu ingresso na PM, também considera que não é determinante e que outros fatores podem incidir sobre a questão.

\section{4 - Paz: Conceito e valor}

\section{Trecho 1 (linhas 329 a 352)}

"P: Atualmente a gente houve falar muito sobre a paz. O que você considera como paz?

S: (pausa média). Paz, eu acredito que seja a pessoa poder sair da sua casa e... Ter uma chance assim, maior de voltar da mesma forma que ela saiu, sem que alguém venha tentar furtar seus bens, ou até mesmo roubar ou atentar contra sua vida. Acho que seria mais ou menos nesse sentido!

P: Você acha que é possível no mundo de hoje, construir uma Cultura de Paz?

S: (pausa longa). É possível! Só que tem que ver se o ser humano está disposto a isso!

$\mathrm{P}$ : Como seria isso?

S: É... não adianta lutar contra o sistema se tiver com... Se tiver praticamente sozinho! Tem que acarear mais pessoas, mais recursos, e fazer... Promover, esse projeto de paz!

P: Você acha que a sociedade atual caminha nessa direção?

S: A sociedade está caminhando pra ser cada vez mais individualista. Acho que pelo sistema capitalista e outras coisas mais, a tendência é... Aquela questão de hospitalidade, principalmente que tinha aqui no Brasil, tá acabando. Por quê? Pela própria característica da violência. Antes... Eu até tava comentado isso com a família, antes a gente tinha o prazer quando chegava alguém desconhecido, estava precisando de alguma coisa ou um entregador de alguma mercadoria "Entra aqui e tal, quer um café? Alguma coisa?" Hoje já não é tão aconselhável fazer isso! Então a tendência da pessoa é se reservar num condomínio fechado, num apartamento e se isolar do mundo o máximo possível. E fica difícil essa integração e essa política de paz, fica complicado pelo cenário atual!"

\section{Trecho 2 (linhas 353 a 360)}

"P: Você acha que a Polícia Militar promove a construção da paz?

S: (pequena pausa) Ela tenta... com alguns trabalhos preventivos que eu já citei, com o fato de às vezes um patrulhamento ostensivo. Só que é insuficiente devido ao contexto que a gente vive! Principalmente por causa da legislação. A própria sociedade, quando a gente 
coloca uma matéria no site da Polícia Militar, ela mesmo já fala: "De que adiantou? Amanhã esse cara já tá na rua de novo brincando com a cara de vocês aí e cometendo crime!""

Trecho 3 (linhas 363 a 376)

"P: E o CFO, você acha que ele promove essa construção da paz?

S: (pausa média). Sim! Mas às vezes não... não tanto como deveria ser, poderia ser melhor... Mas constrói sim, quando ele coloca ali uma sequencia de ações pro policial agir de acordo com determinada ocorrência, de acordo com determinado cenário... Isso já é uma caracterização de... De uso progressivo da força, por exemplo, com a disciplina que eu citei... Isso é uma forma de construção da paz!

P: Em que você acha que poderia ser melhor?

S: Porque ali é uma luta constante, que é outra coisa que eu condeno também, o sistema de competição pra classificação e ali não promove integração, é falsa integração! Se brincar sai nos tapas! É ridículo! $\mathrm{E}$ aí dá vazão pra sentimentos de falsidade, de injustiça, de preconceito... sou contra! Totalmente contra! Eu acho que deveria ter outra forma de avaliação. Os policias ali, meio que vão se unir por interesse próprio, e não por interesse geral, por exemplo. Já começa errado! Eu sempre condenei essa forma porque já começa desunindo..."

\section{Análise 4}

Primeiramente vemos um conceito de paz voltado quase que exclusivamente para 0 sentimento de segurança, onde a pessoa não sofra nenhum tipo de atentado: "sem que alguém venha tentar furtar seus bens, ou até mesmo roubar ou atentar contra sua vida". Ou seja, um conceito por exclusão. Em contraste com Gabriel, ela percebe a paz como uma questão tipicamente da ordem do social, deslocando a questão do conceito de paz subjetiva, do senso comum, para o conceito de paz na relação, na interação entre as pessoas. $A$ frequência de pausas, entretanto, parece indicar que o tema da Paz não te sido objeto de constante elaboração, assim exigindo que ela pare para pensar sobre o assunto.

Ela acha possível construir uma Cultura de Paz, desde que o ser humano esteja disposto a isso, pois, segundo sua análise a sociedade está cada vez mais individualista "Por quê? Pela própria característica da violência". Ou seja, parece um círculo vicioso: a sociedade está individualista por causa da violência, e a Cultura de Paz não se instala porque a sociedade é individualista. Suzana considera que a PM tenta promover a paz, mas não consegue "Principalmente por causa da legislação" e cita comentários das pessoas a respeito. Aqui observamos uma exclusão de responsabilidade: a PM não faz mais porque a legislação não permite, não considerando que várias ações internas da corporação não dependem de legislações externas para serem realizadas. Sobre o CFO promover a Cultura de Paz ela 
também faz uma reflexão ampla, mostrando o que ela considera positivo e negativo. Vale ressaltar uma fala bem categórica e permeada por sentimento "é outra coisa que eu condeno também, o sistema de competição pra classificação e ali não promove integração, é falsa integração!". Aqui observamos não só uma análise crítica, mas afetiva das situações geradoras de hostilidade entre os próprios colegas que foi vivenciada no passado, e que podem dificultar a construção da paz.

\section{5 - Formação do Oficial na PM}

\section{Trecho 1 (linhas 108 a 121)}

"P: Você acha que a PM tem se preocupado com essa formação? Você acha que o CFO possui disciplinas que tratam dessa temática que estamos conversando?

S: Começaram a ser inseridas aí algumas disciplinas como Direitos Humanos, Gestão de Pessoas que trata da liderança né? E não da chefia autocrática. Algumas disciplinas tem trazido isso. Só que eu acho que são... Não são tão suficientes. A própria Psicologia também, tem sido muito importante, que estuda ali a preocupação com a mente do policial né? Que realmente é o importante, por que é algo totalmente afetada dependendo da sua ação. Uma ação, por exemplo, numa troca de tiros, ou até mesmo o desgaste que ele tenha com o cidadão... A primeira coisa a ser afetada realmente, é a sua parte psicológica. E esse transtorno não se restringe a ele, porque atinge ele, a família, até mesmo os próprios colegas de trabalho e a Polícia Militar como um todo. Então essas disciplinas tem sido primordiais, eu acredito que pode... Pode melhorar mais na inclusão delas e até mesmo aprimoramento de outras disciplinas também..."

\section{Trecho 2 (linhas 124 a 132)}

"P: Você que é recém formada, você acha que seu CFO contemplou essa discussão?

S: É... Eu tive, eu tive essa sorte de ter essas disciplinas. Direitos Humanos, Policiamento Comunitário, igual eu mencionei, a Psicologia também foi muito importante, tive 2 instrutores excelentes... Que a gente aprendeu bastante! Era até mesmo assim... 2 não, 3! Eu tive 3 instrutores na área de Psicologia. E essa era a aula que a gente mais se sentia à vontade, que a gente mais relaxava daquele stress do curso de formação... A gente se identificava bastante, era interessante o gosto era unitário assim... De todos, era unânime sabe? Então, acho que contemplou sim..."

\section{Análise 5}

Sobre a formação ela fala de algumas disciplinas que considera "primordiais" na discussão da temática de paz e violência, fazendo referência à área de Psicologia, Direitos Humanos e Policiamento Comunitário. Apesar de demonstrar contentamento, sugere que a formação 
ainda pode ser melhorada nesse aspecto, especialmente no que tange à valorização da liderança em contraposição a uma "chefia autocrática". Interessante ressaltar a análise: "Uma ação, por exemplo, numa troca de tiros, ou até mesmo o desgaste que ele tenha com o cidadão... A primeira coisa a ser afetada realmente, é a sua parte psicológica". Ela consegue relacionar as disciplinas que estudou na APM com aquilo que ela observa na prática, exercendo função de comando, considerando esse postulado como uma verdade. Apesar da formação não dar ênfase na temática da pesquisa, ela acredita que sua formação foi a contento.

\section{6 - Prática policial}

\section{Trecho 1 (linhas 92 a 101)}

"P: Como você acha que a PM orienta os policiais nesse sentido de conduzir suas ações?

S: (pequena pausa) Anteriormente eu acho que eles não se importavam muito com essa dosagem da ação do policial, até mesmo porque a parte jurídica e o conhecimento da própria sociedade eram menores. Então assim, era meio que inconsequente as ações dos policiais. A partir do momento que a policia foi vendo que a sociedade tem evoluído, que cada vez mais o cidadão tem consciência dos seus direitos, essas ações e esse ensino nas academias de formação policial têm sido pautadas na legalidade. Até mesmo pra evitar maiores transtornos, tanto pro próprio policial, quanto pra corporação!"

\section{Trecho 2 (linhas 255 a 272)}

"P: Agora gostaria de saber se você já teve que enfrentar alguma situação que envolvesse violência, na sua carreira da policia.

S: Já, já tive que enfrentar sim!

$\mathrm{P}$ : Como foi?

S: Um caso de uma criança que ela tinha sido abusada... No quintal da casa dela tinha um lote baldio, ela tinha eu acho se eu não me engano, nove anos, aí chamaram a gente pra atender essa ocorrência, a gente fez uma busca, uma varredura total lá no setor por horas. Acabamos encontrando o... autor do crime e... Quando a gente fez tipo uma acareaçãozinha, mas a gente colocou ela na viatura né? E pediu pra ela ver realmente, pra gente não cometer injustiça, pra ela olhar... Colocamos ele do lado de fora, sem saber que ela estava dentro da viatura, ela reconheceu ele na hora, até abaixou o rostinho com medo né? E aí a gente teve que tomar as medidas necessárias pra poder fazer a condução dele. Nessa hora não deixa de causar muita raiva... Muito sentimento de revolta em todos os policiais. Mas a gente ali, ainda mais na frente do comando da operação, a gente tenta controlar os ânimos! E... Nessas horas a gente não tem muita... Muito trato. Trata diferente! Não vou ser hipócrita de falar "ah, é da mesma forma, por exemplo, se eu pegasse um estelionatário". Não é! 
Então nessas horas acho que a violência acaba imperando um pouquinho!"

Trecho 3 (linhas 276 a 303)

"P: Nessas situações, por exemplo, você acha que os policiais tomam a dor da vítima?

S: Sim! Sempre! A maioria! Não só nessa... Essa é a que mais consegue abalar o policiais é essa! Situação de crime sexual, principalmente contra criança... Mas ladrão também, acaba que fica com raiva, às vezes a própria abordagem... Quando aborda e vê que o cara tem passagem né? $\mathrm{O}$ individuo tem alguma passagem por roubo, já vi várias vezes assim, o tratamento já evolui. Já não tem aquele respeito né? Já foge, porque você já está lidando com um marginal! E sabe que virou as costas, ele vai ali cometer o crime de novo! E a gente já sabe, pelo porte físico, pela conversa e pela incidência! As passagens... Já muda até o nível da abordagem! Ás vezes estava conversando tranquilinho e começa a falar mais alto, já não deixa ele falar muita coisa...

$P$ : Então, de uma certa forma, a violência que o policial exerce num momento como esse, seria fruto de uma revolta ou indignação com a situação?

S: Sim! E às vezes nem é tanto com a situação do criminoso... Dele ter escolhido essa vida e dele estar ali cometendo crimes, mas assim... É um conjunto de fatores que, por exemplo, que às vezes ele deu o flagrante ali do roubo, ele vai levar o individuo pra delegacia, e às vezes ele vai sair primeiro que o próprio policial que está ali fazendo o termo! É um problema de legislação. É um problema que foge mesmo da alçada da Polícia Militar! Por isso que eu falo... Muitos usam o termo lá né? "Enxugando gelo, falsa sensação de segurança..." tudo isso aí combina pra um trabalho desmotivado do policial militar!

$P$ : Esse mesmo policial que agiu com violência nessa situação específica, em outra abordagem, você acha que ele agiria de forma diferente?

S: Sim! Quando o cidadão é realmente uma pessoa de bem... Ele levantou certa suspeita ou teve abordagem, verifica ali os antecedentes, verifica se o rapaz, ou a moça... Mulher tem emprego fixo, que ele tem bons antecedentes, tranquilo! "Abordagem padrão da Polícia Militar. Policia agradece, tenha um bom dia cidadão!" Bem diferente!"

\section{Análise 6}

A respeito da orientação para a prática policial, Suzana considera que na medida em que a sociedade foi evoluindo e os cidadãos começaram a ter mais consciência de seus direitos "essas ações e esse ensino nas APMs de formação policial têm sido pautadas na legalidade". Segundo ela, "Anteriormente eu acho que eles não se importavam muito com essa dosagem da ação do policial". É uma afirmação um tanto complexa, pois desde sempre a ação da PM, como uma instituição de Segurança Pública, deveria ser pautada na legalidade. Ela também traz uma informação interessante, relatando que a forma de 
abordagem da PM é diferente conforme a pessoa: quando se trata de um "cidadão de bem", sem antecedentes criminais, segue a abordagem padrão (prevista no POP); quando é um "marginal", com passagens comprovadas, alcança o lado afetivo dos policiais envolvidos na ocorrência e a "abordagem evolui", ou seja, pode sair do padrão e incluir violência. Essa é uma prática que ela presenciou no exemplo citado, em que ela própria como comandante da operação, teve que conter a revolta de sua equipe frente à um crime de abuso sexual infantil. Em sua fala, ela diz que "Não vou ser hipócrita de falar 'ah, é da mesma forma, por exemplo, se eu pegasse um estelionatário'. Não é! Então nessas horas acho que a violência acaba imperando um pouquinho!" O que, na verdade, seria esta violência "imperar um pouquinho"? Aqui observamos a importância da subjetividade que atinge a prática policial, bem como a necessidade de seu equilíbrio emocional diante de uma situação adversa como um crime.

\section{7 - Conflito e suas funções}

Trecho 1 (linhas 382 a 392)

"P: Agora eu gostaria de falar um pouquinho de conflito. Como você definiria conflito?

S: A pessoa entra em conflito com outra pra promover uma mudança benéfica.

P: Como assim? Pode me dar um exemplo

S: Às vezes tem uma pessoa no comando, por exemplo, e ele tá agindo de forma arbitrária com todo o seu efetivo, aí chega uma outra pessoa e começa a entrar em conflito com ele... "Vamos mudar, vamos por esse caminho aqui, ele trás mais benefícios, mais paz, mais integração..." E eles começam ali então, um conflito. "Ah, então me mostra, por quê? Se você conseguir me convencer..." E aí, esse conflito é positivo! Trouxe mudança positiva pra $\underline{\text { todos!" }}$

\section{Análise 7}

Suzana traz uma definição de conflito simplista, onde considera apenas o aspecto da "mudança benéfica", o que é bastante interessante considerando sua profissão, que lida com conflitos graves diariamente. Parece que ela percebe o interesse da pesquisadora e segue nesta linha de raciocínio "da paz"... Traz um exemplo de conflito positivo "Vamos mudar, vamos por esse caminho aqui, ele trás mais benefícios, mais paz, mais integração...", coerente com o que antes conceituou como conflito, algo que vai promover mudança positiva para todos. De fato, uma conceituação surpreendente!

\section{8 - Análise das imagens}

Imagem 1 - Civil chutando o rosto de um policial militar (linhas 432 a 437)

"P: Bom, agora vou te mostrar algumas imagens, e eu quero que você me fale, quais 
sentimentos elas despertam em você. A primeira é essa (mostrando imagem).

S: Indignação!

$\mathrm{P}$ : Mais algum sentimento?

S: Muita indignação!"

Imagem 2 - Policiais militares agredindo um civil (linhas 448 a 446)

"P: A segunda é essa. (mostrando imagem).

S: Essa me gera dúvida, por que depende da situação. Como eu não estava lá no momento... Se esse cidadão fez algum mal, alguma coisa que contraria a lei, algum ato ali, ou tá oferecendo uma certa resistência, cabe provocar alguma contenção, que pode gerar alguma lesão nele. Agora se ele tá contido, tá traquilo, já tá imobilizado, aí já acho errônea a situação. Superioridade numérica né? Quatro policiais, ele tá meio que subjugado, então não cabe ali lesão contra sua integridade física. Por isso não tem como definir em uma palavra, tinha que ver melhor a situação..."

Imagem 3 - Coronel da PM agredido em uma manifestação (linhas 454 a 459)

"P: Terceira imagem (mostrando imagem).

S: O policial está lesionado né?

P: Sim

S: Mais uma vez indignação! Se for... Tudo indica que estava no serviço de função, porque está fardado, então se ele foi lesionado, foi por alguém criminoso! Pra mim indignação, ver um policial lesionado!"

Imagem 4 - Policiais fazendo contenção de um civil em manifestação (linhas 460 a 465) "P: E a última é essa aqui. (mostrando imagem).

S: Cumprimento da missão ai. Se chegou a imobilizar ele é porque tinha necessidade. Não tá nem imobilizando, é uma forma... Uma técnica de imobilização, não envolve nada mais grave não!

$\mathrm{P}:$ Algum sentimento?

S: Sentimento de dever cumprido!"

\section{Análise 8}

Predomina o sentimento de indignação as imagens com policiais militares agredidos. $\mathrm{Na}$ imagem 2 há uma tentativa de relativização da cena: "depende da situação". Ela até faz uma consideração: "Superioridade numérica né? Quatro policiais, ele tá meio que subjugado, então não cabe ali lesão contra sua integridade física", mas ainda assim considera "tinha que ver melhor a situação...". Na imagem 4 "Sentimento de dever cumprido!". Observa-se uma tendência de proteção à ação policial, apesar das críticas que ela considerou ao longo da entrevista, em relação às imagens, esse corporativismo foi evidenciado. 


\section{9 - Análise do vídeo}

\section{Trecho 1 (linhas 466 a 488)}

"P: Certo! Agora eu vou te mostrar um vídeo, e peço que você me fale qual seu sentimento em relação a ele (mostrando vídeo).

S: É um sentimento assim revoltante, por que a sociedade que está ali representada, ela tá representada por uma massa, uma massa totalmente viciada, que é a forma de resolver o problema do país. É causando violência contra a autoridade pública do policial e contra o patrimônio! Depredando o patrimônio publico que fica abrigando ali os políticos. Sendo que o real culpado é a própria sociedade que elegeu aquele que, agora, eles tão querendo derrubar do poder. Então, como sempre, no Brasil, que é característica do brasileiro, tentar resolver o problema pela via transversa, e não pelo cerne mesmo da questão, que é pela eleição, pela educação do cidadão. E sempre querer o meio mais rápido que é o meio impróprio. Sempre o meio mais rápido nunca é eficaz, em tese, mas causa ali transtornos irreversíveis. Que transtorno irreversível? Igual mesmo, a integridade física daquele policial. Que teve sua cara toda manchada. Ele tá ali pra defender a sociedade, pra defender todo o ornamento publico e ele se vê como um criminoso! Na mão de arruaceiros. Em tese, esses manifestantes, na maioria, são defensores do back, das drogas ilícitas, e querem pagar ali um mistério, como se eles fossem ordenadores da lei, e não são! Aproveitam da situação. Então traz indignação pelo fato da Polícia Militar ter que contornar essa situação que... Não deveria existir! Se eles fossem realmente inteligentes, os manifestantes, essa situação não estaria ocorrendo!

P: Por quê?

S: Não estaria ocorrendo, por que isso daí é fruto de um voto deles, no passado!"

\section{Análise 9}

A análise do vídeo mobiliza em Suzana o sentimento de indignação e revolta, pois ela considera que a PM acabou sendo atingida por uma falta de respeito e preparo dos manifestantes, que ela considera como sendo "característica do brasileiro, tentar resolver o problema pela via transversa". Aqui ela faz uma generalização, de que todos os brasileiros agem "pela via transversa". Segundo ela sua explicação "traz indignação pelo fato da Polícia Militar ter que contornar essa situação que... Não deveria existir", ou seja, as pessoas votaram errado e agora vem manifestar descontando sua insatisfação na PM. Ou seja, faz uma avaliação sumária e simplista da situação, primeiro generalizando motivações excusas para todos os manifestantes-e não apenas considerando os arruaceiros-e depois dizendo que o problema em pauta é consequência direta da escolha, pelo voto, dos governantes. Não Ihe ocorre que a manifestação esteja ocorrendo exatamente porque o governante prometeu uma coisa e fez outra, por exemplo. O posicionamento de Suzana também dialoga com o de 
seu colega Gabriel, ao considerar que a PM não tem nada a ver com o problema e acabou sendo atingida, xingada e desrespeitada no cumprimento do seu dever. Novamente prevalece aqui o corporativismo, e a ausência de um posicionamento crítico e criterioso da situação, que emerge como uma expressão do sentimento de pertença ao grupo, mobilizado pela via afetiva.

\section{0 - Sugestões e ideias para a PM promover a Cultura da Paz}

\section{Trecho 1 (linhas 502 a 517)}

"P: Pra finalizar, lembrando que a pesquisa é totalmente sigilosa, você teria mais alguma sugestão ou ideia pra PM, a respeito de como construir uma cultura de paz,?

S: Trabalhar na formação da criança é importante, acho que tem que reforçar! Não só o PROERD, mas também criar outras frentes... De aproximação da sociedade. É... Por que é nessa hora ai que a gente está construindo realmente o nosso futuro! Amanhã a gente vai embora e depois são eles que assumem! E principalmente a valorização do policial, porque não adianta eu querer arrumar a casa lá fora se eu não arrumei minha própria casa né? Então o que a gente tem hoje são policiais desmotivados, que não se sentem valorizados, que não se sentem protegidos... Muitas vezes o cidadão lá fora, até mesmo... Uma pessoa que não é cidadã... Um marginal tem mais valor, às vezes, que o próprio policial... No que tange a palavra e até mesmo respaldo, às vezes um marginal... Quantas vezes eu levei um ladrão pra delegacia e o advogado já tava lá... Nem eu tenho advogado! E o cara tem e saiu primeiro que eu, e eu ficava lá parecendo boba! Então assim, eu acho que tem que trabalhar o público interno primeiro!"

\section{Análise 10}

Duas sugestões que reiteram o que ela pondera durante toda a entrevista: 1- "Trabalhar na formação da criança é importante, acho que tem que reforçar! Não só o PROERD, mas também criar outras frentes...", pois considera sua própria história com a PM como um exemplo. Nesse sentido, começar de casa e com as crianças são, para ela, as melhores iniciativas. A outra sugest 2- "E principalmente a valorização do policial, porque não adianta eu querer arrumar a casa lá fora se eu não arrumei minha própria casa né?". Aqui ela faz uma fala forte sobre a necessidade de valorização do policial no próprio contexto da PM: Muitas vezes o cidadão lá fora, até mesmo... Uma pessoa que não é cidadã... Um marginal tem mais valor, às vezes, que o próprio policial... Uma consideração importante, tendo em vista seus posicionamentos sobre a formação, e suas críticas em relação a como a PM pode melhorar para promover uma Cultura de Paz. 


\subsubsection{Análise Entrevista Tenente Jonas}

\section{1 - Significado da carreira de Oficial da PM}

Trecho 1 (linhas 6 a 13)

"PESQUISADORA: Eu gostaria de começar perguntando sobre o que te motivou a ingressar na carreira de oficial da Policia Militar?

JONAS: Bem, a Polícia Militar, ela é uma instituição forte, que tem valores determinados. Que luta pela justiça, em geral né? E isso é um atrativo muito grande! Além do salário, claro, que é uma coisa que traz estabilidade pras pessoas né? Então isso foi o que determinou realmente o que eu gostaria de... É... De ter como carreira... Naquele momento pesei todos esses fatores e isso fez com que eu prestasse o concurso e cada vez mais eu quisesse estar dentro da corporação."

\section{Análise 1}

Jonas traz duas motivações para sua escolha pela carreira da PM. O primeiro relacionado aos valores institucionais: "a Polícia Militar, ela é uma instituição forte, que tem valores determinados. Que luta pela justiça, em geral...". E o segundo, relativo à questão salarial: "Além do salário, claro, que é uma coisa que traz estabilidade pras pessoas". Interessante ressaltar, que ele é oriundo de outro estado e foi para o Estado $X$, exclusivamente por causa do concurso. Ou seja, fez uma opção não só de carreira, mas de mudança de vida.

\section{2 - Avaliação da PM}

\section{Trecho 1 (linhas 23 a 41)}

"P: E o que você considera como seu ponto forte na polícia?

J: Bom, é difícil falar de nós mesmos né? A gente gosta de sempre fazer o melhor, mas ás vezes a gente tem que reconhecer as nossas fraquezas... Nesse sentido acho que o meu ponto forte seria a interrelação. Saber dialogar com as pessoas, de forma direta, sem ofender, e de forma que não seja opressor... No caso, eu sou oficial e eu tenho que dar uma ordem, essa ordem muitas vezes pode ser dada de várias formas! E a interação toda com a tropa, de explicar, de tentar coordenar o serviço, eu acredito que facilita muito lá na hora! P: Uhum...

J: Essa é a parte mais forte que eu tenho! Saber dialogar. A parte operacional em si, é quase o mesmo... Eu tenho um nivelamento bom... É médio, ele não é ruim nem é bom, é médio... Então eu acho que isso hoje, faz toda a diferença! O que mais destaca do meu serviço operacional é isso, saber lidar com os... Recursos humanos! O grande problema hoje da PM, não é falta de efetivo, não é falta material, é o saber lidar com o grande números de pessoas, com pensamentos diferentes, frustracões diferentes... $E$ sendo que ás vezes a ordem do 
oficial vem pra aniquilar e amassar qualquer tipo de vontade, ou autonomia daquele policial. Então, todo diálogo e explicação que nós damos a respeito do serviço, de como deve ser feito, e o porquê disso, eu acho que facilita muito o meu serviço e não só a realidade daquela área."

\section{Trecho 2 (linhas 44 a 58)}

"P: Você gosta de fazer parte da Polícia Militar?

J: Gosto... Em partes, em partes. É... Tudo na vida nós temos o lado bom e o lado ruim, nós temos as frustrações, nós temos as coisas boas da PM também, que é uma carreira bonita, é uma carreira que nós temos uma coisa bem distribuída, é... Um quadro de oficial que se tem previsão de ser comandante, de ser gestor. No começo é executor, mas nós temos a previsão de ser um gestor da PM, um pensador né? Mas tem um outro lado que o militarismo ele... Não é que ele peca, ele é uma coisa assim, que não atualizou diante da realidade que nós temos hoje! Que é a sociedade civil ela tá cada vez mais se distanciando do militarismo. O militarismo em 1982 quando ele terminou, ele já perdeu uma certa força porque era muito próximo da sociedade, a sociedade convivia com isso né? Uns gostavam outros não! Então o que acontece? Diante disso nós temos vários desvios por parte do policial militar! Que são cobrados depois no gabinete. Eles não sabem lidar emocionalmente e nem profissionalmente com essa discrepância! Tem que lidar com pessoas civis que estão num estado de espírito de bem estar social, que nós aqui estamos presos ao regime assim... Autoritário né? "

\section{Análise 2}

Ele considera como seu ponto forte a "interrelação", a capacidade de dialogar com as pessoas no seu trabalho, considerando que exerce função de comando. Segundo sua análise, a maior deficiência da PM hoje "é o saber lidar com o grande números de pessoas, com pensamentos diferentes, frustações diferentes...". Relata gostar de fazer da PM, mas "em partes". Pondera que "é uma carreira bonita", com um quadro de ascensão na carreira bem distribuído, no qual ele terá chance de ser um "gestor", "um pensador" e considera isso como ponto positivo. Porém, a parte que ele critica é o fato que a instiuição "não atualizou diante da realidade que nós temos hoje!". De acordo com sua análise, o militarismo não acompanhou a evolução social e essa relação do policial militar com o cidadão civil tornou-se dificultada porque "Eles não sabem lidar emocionalmente e nem profissionalmente com essa discrepância!". É uma análise um tanto complexa, considerando que o foco do trabalho da $P M$ é no atendimento ao cidadão civil, e se o militarismo dificulta essa relação então a PM já deveria ter revisto isso há muito tempo. Tudo indica que, para ele, o maior problema está no autoritarismo e na qualidade das relações e interações sociais, dentro e fora da PM. 


\section{3 - Violência: Conceito e Valor}

\section{Trecho 1 (linhas 106 a 124)}

"P: Então falando das práticas, você diria que as ações da Polícia Militar envolvem algum tipo de violência?

J: Eu acredito que atualmente, é... A policia é preparada pra determinados tipos de ocorrência e fatos da sociedade... Né? Por exemplo, hoje se fala muito de violência doméstica... A violência doméstica, hoje, a policia, ela é preparada porque tem uma lei que resguarda, ela não precisa agredir! O policial não precisa agir de forma... Agredir nem a vítima nem ao autor, pra separar um do outro. Porque a própria lei já resguardou. Quando o policial chega no local, há um acionamento do vizinho de um conhecido... O policial chegou, a agressão cessa nesse momento! Então não é que a policia esteja preparada, ela tem um respaldo que garante que naquela ação, a violência dela vai cessar! Agora um exemplo clássico, uma confusão generalizada num terminal de ônibus. A policia, o único meio que ela tem pra lidar, geralmente é com uma unidade especializada, nesse caso, que é o Choque, Controle de distúrbios civis...

P: Uhum...

J: Eles usam armas não letais, mas que são violentas né? Apesar de se tentar propagar... Ter um líder, em volta dessas pessoas, mesmo que estejam reivindicando algo... Sempre tem uma briga, e o líder que toma a frente e tenta conversar com a polícia... Isso é muito difícil! É... Então, utiliza-se muito da violência. Gás... É... Elastômero, essas coisas, elas são pra garantir a ordem, mas são violentas!"

\section{Trecho 2 (linhas 118 a 130)}

"P: Você acha que as ações violentas da PM, elas se justificam?

J: É... Depende!

$\mathrm{P}$ : Como seria isso?

J: Algumas coisas justificam. Por exemplo, a manutenção da ordem, é... Como se utiliza de meios violentos... Hoje não foi criado, acredito que fora do Brasil ou dentro do Brasil, algum meio que você evite, que você tenha que proteger alguma coisa utilizando violência, ainda com número de pessoas violentas maior... Que a polícia trabalha com superioridade numérica. Por que? Pra intimidar... É o medo! É o medo! Por causa... Ele é de uma certa forma, uma violência! Uma violência psicológica né? $E$ hoje... Ah... Teve até numa manifestação um ataque ao Congresso Nacional! O que se utiliza hoje? Cavalaria, choque, gás... É o meio que nós aprendemos... Que é o certo pra garantir... Garantir o estado democrático de direito! Nesse caso se justifica!"

\section{Trecho 3 (linhas 152 a 166)}

"P: Afinal, o que você entende como violência? Se você tivesse que explicar pra alguém. 
J: Violência? (pausa média) Conceito difícil hein? (pausa média) Violência, eu acredito que seja qualquer violação ou agressão de uma pessoa contra outra ou uma entidade contra outra, de forma física, psicológica ou moral e de forma injusta. Eu acredito que seja isso, porque ela é muito ampla. A agressão, a violência hoje, ela tá no dia a dia, no cotidiano. Ela se dá de uma pessoa contra outra, ela se dá de uma empresa contra uma pessoa, de uma pessoa contra uma empresa, por motivos não justificados... Então se dá de várias formas! $\mathrm{E}$ não só física né? Como a lei Maria da Penha resguarda... O simples fato de você criar um constrangimento psicológico contra a mulher, já é uma violência!

P: Ummm...

J: Aí já justifica toda essa ação. Então pra ser violência, ela tem que ser injusta contra uma pessoa ou entidade. Que pode ser por escrito, que pode ser física, que pode ser moral né? De forma injusta!"

\section{Trecho 4 (linhas 167 a 178)}

"P: Quando que você acha que uma pessoa precisa utilizar de violência?

J: Quando não houver outro recurso! Violência é utilizada pra se defender... Só pra se defender! Eu acho que o direito do outro tem que ser resguardado! A violência, eu acredito que ela tem que ser utilizada em caso de legítima defesa, quando você que tá sendo agredido!

P: Nesse caso você acha que ela é necessária?

J: Necessária! Necessária! Por exemplo, um rapaz passa na rua e alguém mexe com ele e ele não responde, essa pessoa que mexeu com ele vai pra cima dele, "tô falando com você". Pega uma faca e vai em direção dele. Ele tem que se defender, porque senão ele tá colocando a vida dele em risco! Ele tem que se defender... Ela tem que usar todos os meios possíveis pra salvar a vida dela, mesmo ceifando a vida do outro, se for necessário!"

\section{Trecho 5 (linhas 265 a 292)}

"P: Sabemos que sempre é melhor prevenir do que reprimir, mas será que é possível prevenir todo tipo de violência?

\section{J: Não!}

P: Por quê?

J: Por que... (média pausa) É... Quando a pessoa, ela tem uma certa realidade, e pra ela, ela não consegue enxergar outra coisa senão como uma vingança, uma revanche, uma violência, como... Acredito que grande parte do povo brasileiro hoje, ela utiliza-se de meios violentos também. Por exemplo, uma pessoa que não tem emprego, que não tem estudo, que não teve uma estrutura familiar, ela utiliza de meios violentos pra tentar se auto firmar e mostrar sua importância, dela pra sociedade... Né? Nós temos outras situações também, de pessoas desviadas, que são de classe média, média alta e até alta, que muitas vezes gostam 
e utilizam de seus poderes... Seu poder econômico pra tentar fazer da violência uma forma de imposição.

P: Ummm...

J: Não sei se é por causa da frustração profissional, e não se sabe também se é a única forma da pessoa... Se é a natureza da pessoa, que ela sabe lidar! Nós temos grandes pessoas que ganham muito dinheiro e utilizam-se da força ao invés do diálogo, da inteligência, da mídia ou de qualquer outro meio, pra tentar mostrar o contrário. Nós temos exemplos clássicos na sociedade né? Então a violência, por exemplo, um crime de homicídio. Quando uma pessoa tá determinada a cometer homicídio, eu acredito que não há nada que faça ela mudar, porque uma pessoa que tá diante... Uma pessoa que é... Religiosa, que tem família, que tem filho, que tem mulher, que tem pai, que tem mãe... Pra ele resolver cometer um homicídio, é porque alguma coisa dentro do funcionamento psicológico não está bem! Nada bem! Ou então tá muito desviado pro lado que... É de muita raiva, muito... Muito rancor, e é a única coisa que ela vê como solução para os problemas dela... Né? Então, ela tá determinada a fazer isso. E ela pode ser uma pessoa próxima dessa vítima, pode não ser, né? É... Então é uma coisa que é muito difícil de prevenir né? E de saber onde vai acontecer, como vai acontecer e qual é o motivo."

\section{Análise 3}

Jonas faz uma reflexão sobre as práticas da PM, citando exemplo de ocorrências cotidianas como a Lei Maria da Penha, na qual ele considera que a legislação vigente ampara a ação da PM e não precisa agir com violência. Por outro lado, cita a atuação do Choque afirmando que são preparados para agir em situações específicas "Eles usam armas não letais, mas que são violentas". O que ele considera justificável para a situação. Jonas conceitua violência como "qualquer violação ou agressão de uma pessoa contra outra ou uma entidade contra outra, de forma física, psicológica ou moral e de forma injusta". Um conceito bastante abrangente, que engloba as várias formas de violência e a virtude da justiça como um determinante para caracterizar uma ação como violenta. Chama, em especial, a atenção a menção feita por ele quanto à justiça. Pode-se deduzir, pelo que ele diz, que se a ação é justa, não seria violenta! Neste sentido, o exemplo que ele dá sobre uma pessoa religiosa, de família etc que tenha decidido matar alguém ("Quando uma pessoa tá determinada a cometer homicídio, eu acredito que não há nada que faça ela mudar"), se esta pessoa estiver fazendo justiça (matando, por exemplo, um assassino perigoso) isto não seria violência. Aqui, uma contradição não explicada pelo participante, pois o conceito de justiça é extremamente complexo.

Ele considera que a violência é necessária em legítima defesa, quando uma pessoa tem sua 
vida ameaçada "Ela tem que se defender... Ela tem que usar todos os meios possíveis pra salvar a vida dela, mesmo ceifando a vida do outro, se for necessário! Mas e o uso de violência nas manifestações, onde ele diz que ela é necessária? Seria em legítima defesa? Mais uma vez a questão fica mal explicada.

Sobre a prevenção da violência, Jonas considera que algumas situações não são alcançadas, por exemplo "Quando uma pessoa tá determinada a cometer homicídio, eu acredito que não há nada que faça ela mudar". Ele faz uma análise que envolve valores familiares, morais e religiosos e até questiona o funcionamento psicológico de quem comete um crime como esse, para ilustrar que não é passível de prevenção. Nesse sentido, numa análise geral sobre o que ele considera como violência, envolve um emaranhado de fatores entrelaçados que envolvem justiça e legítima defesa, conceitos bastante controversos.

\section{4 - Paz - Conceito e valor}

\section{Trecho 1 (linhas 344 a 358)}

"P: Atualmente se ouve-se falar muito sobre a questão da paz. Como você conceitua paz?

J: Paz... É... (pigarro) A paz, ela é... (pausa média) Hoje em dia um objetivo muito complicado né? De se conseguir. Pode-se falar de uma paz interior, pode-se falar de uma paz da sociedade, paz no geral... Pra se viver hoje na sociedade contemporânea, a paz, ela tem que tá dentro de cada um, porque desse modo a gente vai conseguir exteriorizar alguma coisa de paz pra nossa sociedade. Se as pessoas hoje, só vivem violência, e tem dentro do coração violência, e ligam a televisão e tem violência, ela não pode transmitir paz. Ninguém transmite aquilo que não tem. Então a paz eu acredito que... Apesar das igrejas estarem fazendo esse papel, umas muito bem, fica difícil né? Fica difícil numa sociedade conflitante, egoísta, capitalista, nós termos uma paz plena. A gente tem uma paz momentânea, uma paz que a igreja nos fornece, que a nossa família nos dá. Aquela felicidade de ter ali, falar: "eu tenho uma família, eu tenho uma casa, eu tenho um amor... E isso me traz certa paz e eu vou trabalhar feliz por causa disso". Mas, por outro lado, nós temos os fatores externos, que é a nossa sociedade. A interdependência de um e outro dentro da nossa sociedade, vivemos numa sociedade que tem que ser solidária, nem sempre isso acontece!"

\section{Trecho 2 (linhas 368 a 375)}

"J: Então a gente tem que delinear o que é paz. O que é paz? Paz é ter tranquilidade? Quem tem tranquilidade hoje? Ninguém! Ninguém tem tranquilidade, ninguém tá a salvo de uma doença, tem tá a salvo de perder o emprego, eu sou funcionário publico, mas é muito dificilmente... Né? Hoje nós não temos tranquilidade na política, no dia de amanhã... Então, a paz é o dia a dia. Você estar feliz consigo, você poder realizar aquilo que está ao seu alcance da melhor forma possível e falar, hoje eu estou realizado! Tenho uma profissão boa, tenho 
minha família. Não tenho muitos bens, mas isso não influencia minha paz, isso influencia no querer viver e no quanto eu preciso pra querer viver."

Trecho 3 (linhas 385 a 399)

"P: Você acha que é possível construir a paz no mundo atual?

J: (pausa média) É... Plena não!

$P$ : Por quê?

J: Porque... Primeiro o sistema econômico que nós vivemos... Da desigualdade capitalista. É desigual, sempre vai ter alguém precisando e alguém sempre vai ter que doar né? $E$ nem sempre esse alguém que vai ter que doar vai estar disposto a fazer isso né? Então... Essa paz plena ela tem que envolver toda a sociedade, como se fosse nivelar toda a sociedade, que é uma coisa que hoje não dá pra fazer! A gente não consegue mais!

$\mathrm{P}:$ Ummm

J: Uma paz, é... Regional, uma paz que você vive com a sua família, na sua realidade, você pode conseguir, mas envolver toda uma sociedade, ou um conjunto de pessoas que talvez vá... Cruzar na vida, não vão se respeitar, não vão... Pela diversidade, a diversidade apesar de ser respeitada, muitas vezes ela não é entendida! Então fica difícil!"

Trecho 4 (linhas 400 a 421)

"P: E você acha que a Polícia Militar, hoje, ela promove a construção da paz?

$\mathrm{J}:$ Parcialmente!

$P:$ Em que sentido?

$\mathrm{J}$ : A Polícia Militar, ultimamente ela tem trabalhado em tentar se envolver com a sociedade. Com reuniões e visita comunitária, estando mais a par das pessoas que estão em volta da área de atuação dela... Né? Dando telefone... Elas são orientadas a conversar com as pessoas né? A não ser ríspida. Antigamente a pessoa... O policial militar era muito ríspido, hoje não, hoje tem o policial que conversa, que entende, que atende as ocorrências de uma forma é... Mais branda, apesar de não deixar, se necessário, a força...

P: Uhum...

J: Não deixar a força de lado né? Então há um entendimento maior entre comandantes, da polícia militar e a sociedade, há interação... Isso por um lado até que é bom né? Você... É... Assim, é uma coisa que precisa tá nivelado. Mas por outro, o policial militar fica um pouco, vamos dizer... É... (pausa média). Ele fica longe do regulamento dele. Como assim? Quando a gente convive num meio, geralmente a gente acaba adquirindo o jeito, a forma, o trato... Do mundo civil. E o que hoje é cobrado na PM, é muito diferente, que eu volto a falar do regulamento. Quando o policial militar se deixa levar pra uma vida civil, depois não consegue reaver um posicionamento de postura e compostura, dentro daquilo que é exigido pelo regulamento militar... Acaba sendo ruim pra ele." 


\section{Análise 4}

Jonas, como os demais, hesita (pausas) antes de apresentar um conceito de paz. Em seguida, traz um conceito de paz amplo, porém sem maior articulação: "Pode-se falar de uma paz interior, pode-se falar de uma paz da sociedade, paz no geral (...) A paz, ela tem que tá dentro de cada um, porque desse modo a gente vai conseguir exteriorizar alguma coisa de paz pra nossa sociedade". Ele traz um misto de paz social com paz interior, considerando que esta (a paz interior) pauta as ações do ser humano. Em seguida, equipara paz à felicidade, que precisa ser vivenciada no dia-a-dia. Considera que não é possível construir a paz no mundo atual, porque "Essa paz plena ela tem que envolver toda a sociedade, como se fosse nivelar toda a sociedade, que é uma coisa que hoje não dá pra fazer! A gente não consegue mais!". Culpa a desigualdade do sistema capitalista, mas não parece considerar que a sociedade também muda, e que o sistema político-social pode ser aperfeiçoado. É conformista em relação ao status quo, e não vê possibilidades de mudanças positivas no sistema. E em seguida fala de uma "paz regional", novamente equiparando ao conceito de felicidade que a pessoa conseguiria atingir no seu mundo, seu ambiente familiar. Jonas considera que a Polícia Militar promove uma cultura de paz "parcialmente", através de sua proximidade com a sociedade (Policiamento Comunitário). Mas faz uma consideração semelhante ao seu posicionamento no item 2, ponderando que a proximidade do policial com o mundo civil, o distancia do regulamento da PM e isso pode prejudicá-lo. Esse é um posicionamento que precisaria ser melhor explorado, tendo em vista que não fica claro o que ele quer dizer com "ser civil" e como isto se chocaria de maneira tão gritante com o "ser militar".

\section{5 - Formação do Oficial na PM}

\section{Trecho 1 (linhas 454 a 472)}

"P: Em algum momento do seu CFO, questões como essas que essas que estamos conversando, foram discutidas?

$\mathrm{J}$ : O meu curso, considero ele diferenciado. Eu não sei como foram os cursos anteriores, mas nós tivemos Direitos Humanos... É... Nós tivemos contado direto com os batalhões, em que se fala muito não só no treinamento né? Se falou muito de Polícia Comunitária, se falou da... Da policia em si, como ela tem trabalhado junto com a sociedade... E aqui dentro da academia mesmo, o tratamento foi diferenciado: ninguém gritava, ninguém maltratava a gente. Simplesmente eles passavam pra o nosso curso, noção de tempo, espaço e como deveriam ser executadas as tarefas né? Eles passavam a necessidade da organização, de se ter uma disciplina né? Então o curso, ele trouxe a disciplina, ele trouxe o despertar pra uma sociedade caótica. Uma sociedade que precisa da Policia Militar, precisa da atividade 
policial, mas que por outro lado está totalmente desorganizada né? $\mathrm{E}$ essa base da organização e saber como as coisas tem que ser feitas, eu acredito que é aqui dentro que a gente tem que embasar as pessoas. Saber os limites, saber o que pode acontece... Né? Isso tudo vem da Academia, porque depois, quando o policial for pra rua, fica mais difícil dele entender que a sociedade tá caótica, tá passando por sérias dificuldades, não só de ordem publica, mas de educação, saúde... De toda ordem possível. E a Policia Militar, no meu curso, eu posso falar, ele foi muito bom!"

\section{Trecho 2 (linhas 475 a 491)}

"P: Você considera que o CFO contribui com a formação de cultura de paz?

J: Sim! Cultura de paz assim... É... Nós tivemos aula de Psicologia, tivemos aula de muitas coisas que acredito que no passado a PM não tinha... Eu não teria, se tivesse feito o curso há uns 10 anos, mais ou menos. Então se empregava muito, operacionalidade, armamento, é... Cursos de unidade especializada, e... A paz em si, ela tá... Implícita! Em tudo que é colocado... Nas nossas disciplinas... Existe a concorrência, existe! Existe o militarismo em si, porque apesar de ter a paz, nós temos a ordem. Tem o regulamento, as normas e como as coisas devem ser feitas. De uma forma bem branda a gente pode falar que teve essa cultura

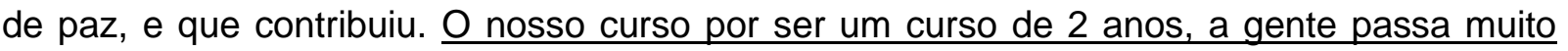
tempo junto sobre uma pressão relativa né? E isso cria um grau de solidariedade no curso, por que um ajuda o outro. Nas intempéries, no alojamento, no dia a dia, na falta de um... uma coisa ou outra, a gente acaba ajudando um ao outro. Cria-se esse senso. Então, eu acredito que isso contribui pra pessoa refletir e falar assim: "Oh... Um dia eu estive nesse estado, nessa situação, eu sei como é que é!" E a gente valorar, e vê isso e poder empregar na rua, eu acredito que... que tem uma cultura de paz e solidariedade, dentro da Policia Militar, no curso de formação..."

\section{Análise 5}

Jonas considera que seu curso (CFO) foi diferenciado, especialmente pela disciplinas de Direitos Humanos, Policiamento Comunitário e Psicologia. Uma análise bem semelhante a de sua colega Suzana. No entanto, diferente da análise dela, ele considera que o curso promove a Cultura de Paz, que existe solidariedade entre os colegas, que a concorrência não atrapalha as relações e que "A paz em si, ela tá... Implícita! Em tudo que é colocado... Nas nossas disciplinas... Existe a concorrência, existe! Existe o militarismo em si, porque apesar de ter a paz, nós temos a ordem". Essa fala é bem interessante, porque considera a paz dentro de um contexto de ordens e normas. 


\section{6 - Prática policial}

\section{Trecho 1 (linhas 308 a 347)}

"P: Você já teve alguma situação que envolveu violência na sua carreira na PM? Algum exemplo, que você tenha vivenciado?

J: Sei... É... Situações de violência a gente às vezes acaba encontrando né? Ás vezes chega depois... No meu caso cheguei numa ocorrência, foi um roubo de veículo, em que a pessoa tava muito drogada, então tinha feito uso de entorpecentes e não queria parar o carro. Nós abordamos, tentamos abordar a pessoa né? E ele não parava, ele evadiu e a viatura e nós... Fizemos o acompanhamento. Ele só parou o veículo porque nós utilizamos duas armas de fogo, mas em direção do pneu, poderia ter vítimas no porta mala, poderia tá com algum sequestro né? Graças a Deus o tiro não pegou em ninguém e ele parou o veículo, esse rapaz. Ele não queria descer do carro, tivemos que tira-lo do carro a força e algema-lo. Porque ele gritava muito, se debatia muito e ele já tava muito sujo... E muito machucado, por que alguém deve ter machucado ele numa ocorrência anterior. Ele roubou... Tentou roubar o primo dele, esfaqueou o primo pra pegar uma moto... Não conseguindo, saiu correndo na rua, tentou esfaquear um Pastor e foi aí que ele conseguiu roubar o carro do pastor e saiu. Como nós não conseguimos abordar, ele tava sujo, machucado... Ele não parava de gritar, a gente via nitidamente que ele tava fora do comum só que a gente não sabia se se tratava de um deficiente mental, de uma pessoa que usava drogas ou se ele estava realmente fazendo teatro. Começou a gritar, a se debater, tentava agredir a gente. Teve que algemar os pés também, até que a gente conseguiu colocar ele na viatura e levamos ele para o distrito policial. Lá ele começou a se debater muito, a xingar muito, e... Tentou cuspir na gente, $\underline{\text { e a }}$ gente teve que conter isso não agressivamente, mas pelo menos tentar imobiliza-lo, sem... Sem, é... É tentar... Diferente de agredir né? A gente tem que contê-lo, tenta conversar... Ele não falava nada com nada, não falava nenhuma palavra concreta... Tanto é, que na nossa abordagem, a gente não sabia se ele era réu ou se ele tava com problema mental e era proprietário. Quando a gente foi verificar o carro, o carro não tava no nome dele, ele não sabia falar de quem que era e só numa busca detalhada... Tinha uma faca cheia de sangue na parte de trás do carro... E o que foi decidido? "Óh, há um índicio de crime", foi quando nós decidimos leva-lo pra delegacia.

P: Uhum...

J: Aí descobrimos que ele era dependente químico, que ele tava albergado, que ele fugiu pra consumir droga... Usuário de droga, viciado em craque né?

$P:$ Você considera que foi uma ação de...

$\mathrm{J}$ : De contenção.

$\mathrm{P}$ : Isso é comum na prática da policia? 
J: Não... Só utiliza quando há resistência... Nesse caso houve resistência, não existe outra forma de conduzir uma pessoa. A pessoa vai... A gente não aprendeu um jeito de convencer a pessoa ir por livre e espontânea vontade. Não vai, não quer e ele acha que tá certo, mas ele cometeu um crime e a gente tem que cumprir os rigores da lei, nessa parte a gente tem que ser legalista pra... Pra resguardar a sociedade."

\section{Trecho 2 (linhas 348 a 358)}

"P: Como você considera que a Polícia Militar orienta seus policiais na forma de agir?

J: Orienta bem! É que assim, são muitas pessoas né? Então cada pessoa tem uma forma de lidar. Mas em regra geral, nós temos superiores excelentes, temos superiores medianos, é... Somos bem orientados né? Porque eles sabem dos riscos, sabem dos problemas que podem ocorrer e sabem que se alguma coisa der errado e culpa é nossa! A culpa é da policia. Apesar de já se presumir que a culpa sempre é do policial militar, nós devemos estar preparados pra lidar com a situação, envolvendo a sociedade de pessoas civis... Então, é... Sabe que a atuação policial ela é difícil, mas a orientação, apesar de breve, ela vem explicar, fala justamente o que é que deve ser feito em tais circunstancias..."

\section{Análise 6}

Sobre a prática policial, Jonas conta uma experiência vivenciada em sua carreira, onde teve que utilizar de violência para fazer uma contenção. Segundo ele, a PM "Só utiliza quando há resistência... Nesse caso (que ele relatou) houve resistência, não existe outra forma de conduzir uma pessoa". Ele considera que a PM orienta bem seus policiais, que os superiores conhecem os riscos da atividade policial e sabem que podem responder por algo errado. Aqui, Jonas refere-se as orientações pontuais, chamadas de "preleção", que são passadas diariamente quando a equipe entra de serviço "a orientação, apesar de breve, ela vem explicar, fala justamente o que é que deve ser feito em tais circunstâncias...".

\section{7 - Conflito e suas funções}

\section{Trecho 1 (linhas 517 a 533)}

"P: Eu gostaria de falar um pouquinho sobre o conflito. O que você considera como conflito? $\mathrm{J}$ : Conflito? (pausa pequena) Seria uma situação de disputa, de eu querer de um jeito você de outro... Acho que envolve opiniões diferentes do mesmo tema...

P: Você acha que existe conflito positivo?

J: Sim! Alguns conflitos são necessários... Dentro da nossa sociedade pra ter uma reeducação. Não existe nessa sociedade atual, uma forma de não ter conflitos, porque o que se tem hoje é a concorrência, a competição. Não tem como ter uma competição saudável sem haver o mínimo de conflito. Não estou falando de um conflito generalizado, to falando de 
um conflito, uma competição é... Que não seja a ponto de ser uma barbárie. Um conflito... Um conflito por espaço, um conflito por desenvolvimento, um conflito por um... É um jeito de estimular as pessoas a melhorarem... Quem tem condição de ter esse desenvolvimento, essa evolução... Querer estar mais bem situado na sociedade... Querer ter é... Um conhecimento melhor, ver a sociedade de outra forma, enxergar o mundo de outra forma né? Não sob a lógica dos outros né? Estar mais tranquilo, ou menos preocupado com isso! Essa eu acho que é uma questão que sempre vai existir na sociedade!"

\section{Análise 7}

Jonas traz uma explicação simplista sobre conflito e voltada ao senso comum. Considera que o conflito pode ser positivo: "Não tem como ter uma competição saudável sem haver o mínimo de conflito". Parece comparar sua definição de conflito à competição, e defende que esta é boa para o desenvolvimento, "estimular as pessoas a melhorarem... Quem tem condição de ter esse desenvolvimento, essa evolução... Querer estar mais bem situado na sociedade...".

\section{8 - Análise das imagens}

\section{Imagem 1 - Civil chutando o rosto de um policial militar (linhas 536 a 546)}

"P: Agora eu vou te mostrar algumas imagens e eu quero que você me fale o que você acha sobre... Sobre elas. Primeiro essa daqui (mostrando imagem 1).

J: Agressão ao policial... Policial vítima! É uma agressão por parte do torcedor né? Que eu acho lamentável né? É... Essa ação é o retrato que a sociedade repudia... Parte da sociedade repudia a atitude da Polícia Militar e como nós temos pessoas violentas dentro dos estádios... Que não respeitam a autoridade da Polícia Militar e que utilizam da violência mesmo... Efetivamente! Então, eu fico é... Com raiva! A gente sente raiva né? Porque o policial tá lá, fardado, trabalhando, tem que intervir, mas não que ele queira... Pra tentar coibir uma ação dentro de um estágio de futebol, que pessoas deveriam estar torcendo pros times e estão na verdade brigando um com outro."

\section{Imagem 2 - Policiais militares agredindo um civil (linhas 547 a 553)}

"P: Uhum... (mostrando imagem 2).

J: Violência policial! Desnecessária! É uma violência por falta de despreparo né? É uma pessoa que por mais que ela tenha causado algum problema ou tenha agredido verbalmente os policias, ela não poderia ser tratada dessa forma! Por que... Uma agressão né? Ela poderia ter sido imobilizada e levada diretamente para a central de policia. Nenhuma ação justifica... Justifica isso aqui! Eu acho lamentável, fico triste! Isso aqui... em relação aos policiais que agrediram eu fico triste!" 
Imagem 3 - Coronel da PM agredido em uma manifestação (linhas 554 a 564)

"P: (mostrando imagem 3).

J: O policial tá machucado... A gente fica um pouco chateado, revoltado, porque a gente não espera isso, mas isso é consequência da nossa atividade, então nós temos que também estar preparados pra isso, pra sermos recebidos dessa forma! Ao longo da história eu nunca ouvi falar que não houve um problema envolvendo a saúde de um policial. É o nosso risco, é o nosso dever! Ele tá bem, ele tá na circunstâncias que for, a gente não sabe. Fica chateado? Fica! O policial, eu acredito que não deveria ter recebido isso! Mas aconteceu! É... Faz parte né? Faz parte da nossa atividade apesar de eu achar injusto!

$P$ : Seu sentimento seria?

$\mathrm{J}$ : Injustiça!"

Imagem 4 - Policiais fazendo contenção de um civil em manifestação (linhas 565 a 572) "P: (mostrando imagem 4).

J: Eu vejo uma imobilização. Uma imobilização em uma pessoa que está numa manifestação, aparentemente e que resistiu. Eu não to vendo efetivamente uma agressão, isso é uma imobilização!

$P$ : Algum sentimento?

J: Não me traz nenhum sentimento específico. Eu acho que o policial tá cumprindo com o dever dele né? Se ele tivesse agredindo, tivesse com a tonfa levantada pra agredir, eu acho que ele estaria errado! Mas eu to vendo uma imobilização!"

\section{Análise 8}

A partir das imagens mostradas, nós conseguimos perceber sentimentos bem específicos. Na primeira imagem predomina a raiva e a revolta: "Policial vítima! (...) Que eu acho lamentável né? Então, eu fico é... Com raiva!". Na segunda: "Eu acho lamentável, fico triste!". Surge até certa vergonha pela ação dos colegas. Na terceira, surge o sentimento de injustiça "É o nosso risco, é o nosso dever! Faz parte da nossa atividade apesar de eu achar injusto!". Apesar dele ainda demonstrar revolta por ver um colega ferido, aqui parece haver um certo grau de conformismo. Talvez uma segunda imagem de um polical agredido acesse um nivel mais profundo de reflexão "faz parte da nossa atividade", que a primeira imagem não alcançou. Na quarta imagem, como os demais participantes, ele considera uma ação comum da PM (imobilização) e o sentimento "Eu acho que o policial tá cumprindo com o dever dele né?". Cabe ressaltar, que Jonas não tentou racionalizar suas respostas deixando que o sentimento se manifestasse, seguindo o que foi proposto. 


\section{9 - Análise do vídeo}

\section{Trecho 1 (linhas 573 a 580)}

"P: Agora eu vou passar um pequeno vídeo, e também peço que você me fale do sentimento que você tem em relação ao que vai assistir! (mostrando vídeo).

J: (pigarro). Eu tava nesse dia, tava nesse local!

$\mathrm{P}$ : O que você sente quando você... Vê essas imagens, ainda mais você esteve lá!

$\mathrm{J}$ : Bom, num primeiro momento, quando eu tava lá, a gente fica indignado, como policial militar né? A gente não sabe muito bem... quando a gente tá lá no meio, o que realmente aconteceu, a gente só vê a movimentação."

\section{"Trecho 2 (linhas 619 a 634)}

$P:$ E hoje vendo esse vídeo, qual é o seu sentimento?

J: Não é de tanta revolta não! A gente vê... Eu achei que foi um excesso por parte da população né? Que eles não pouparam a PM em nenhum momento... Hostilizaram toda... Mas viram que eles estavam errados! Eles estavam pichando patrimônio publico, foram é... Abordados pela policia e eles deveriam respeitar isso, mas isso na pratica não funciona! $\mathrm{A}$ população não respeita isso... Naquele momento! Ai a PM utiliza da força, que foi o meio pelo qual nós aprendemos pra conter e aí acontece esse tipo de situação.

P: Que sentimento você tem hoje então? Você falou menos revolta, mas não conseguiu definir muito bem...

J: Só uma insatisfação pelo ocorrido, uma insatisfação! Porque eu não acho que foi... Apesar de ter tido erro, por parte da PM, eu acredito que a população devia ter respeitado, pelo fato de estarem tentando pichar um patrimônio, se eu não me engano era o prédio do TRT... E a policia foi pra intervir, apesar de ter ido sozinha, eles deveriam ter respeitado, eles estavam errados! E mesmo assim eles conspiraram e fizeram vídeos contra a PM!"

\section{Análise 9}

Muito interessante ouvir de quem esteve no local da manifestação, da qual foi extraído o vídeo, o sentimento que envolveu a situação como um todo. Aqui temos dois momentos distintos: o primeiro onde ele faz memória do que sentiu no dia "num primeiro momento, quando eu tava lá, a gente fica indignado como policial militar né?". E um segundo momento, onde ele reviu a situação por meio desse vídeo: "Não é de tanta revolta não! A gente vê... Eu achei que foi um excesso por parte da população né? (...) Só uma insatisfação pelo ocorrido, uma insatisfação!". Apesar de ainda considerar grande o desrespeito da população para com a PM e também que houve erros por parte dos policiais, ele consegue fazer uma avaliação mais ponderada da situação passada. O sentimento de indignação foi transformada em insatisfação à medida que ele refletiu sobre a situação como um todo, uma atitude bastante 
apreciável. Mas, assim, como os demais participantes, generaliza a hostilidade para todaos os manifestantes: "Abordados pela policia e eles deveriam respeitar isso, mas isso na pratica não funciona! A população não respeita isso... ; "eu acredito que a população devia ter respeitado..."

\section{0 - Sugestões e ideias para a PM promover a Cultura da Paz}

\section{Trecho 1 (linhas 640 a 646)}

"P: Diante de tudo o que nós conversamos hoje e pra finalizar, lembrando que a pesquisa é totalmente sigilosa, você teria mais alguma sugestão ou ideia pra melhorar essa cultura de paz, partindo da PM?

J: Bem, a Polícia Militar, primeiro tem que conscientizar seu policial! Fazer reuniões com os policiais, se não dá pra fazer dentro da APM, que faça nos batalhões, com pessoas conscientes! Não dando só métodos de atividades policiais, mas dando soluções de como deveria ser feita a atividade policial, tendo em vista a nossa realidade!"

\section{Trecho 2 (linhas 652 a 661)}

"P: Você conhece algum programa que já exista na PM que você considera eficaz nessa construção de Cultura de Paz?

J: PROERD! O PROERD eu acho que é o maior... Maior força que nós temos contra o tráfico e o uso de drogas! Porque muda muito a imagem que nós temos, de ser ruim, de não ter coração, de não respeitar a família... Isso muda muito! O POERD, pra mim... É... extremamente importante no significado... Eu não sei o quanto de ação que é feito né? O quanto de trabalho, mas pra mim só de ser semeando, levar pras escolas, levar pros meninos, mostrar o trabalho... Que dali a gente pode mudar o diálogo, mostrar os efeitos, mostrar o quão prejudicial pode ser tudo isso antes deles entrarem... acho que é o melhor programa da PM!"

\section{Análise 10}

As ideias e sugestões apontam para uma resposta bem semelhante à de Suzana: trabalhar com o público interno e fortalecer o Proerd. "a Polícia Militar, primeiro tem que conscientizar seu policial! (...) dando soluções de como deveria ser feita a atividade policial, tendo em vista a nossa realidade!". Nessa fala, ele reafirma o que foi colocado no item 6, sugerindo reuniões na APM e nos batalhões onde os policias possam ser instruídos e levá-los a refletir sobre suas ações nas atividades cotidianas. O segundo trecho, reforça as visões dos colegas: "므 PROERD eu acho que é o maior... Maior força que nós temos contra o tráfico e o uso de drogas!". Jonas considera que o trabalho com as crianças tem um efeito positivo na prevenção da criminalidade e promove a Cultura de Paz. 


\section{4 - GRUPO FOCAL - TENENTES}

Nesta etapa da pesquisa, participaram três tenentes. Inicialmente, foram convidados para participar do grupo focal os cinco tenentes entrevistados individualmente, no entanto, dois tiveram problemas para comparecer ao local e horário marcados devido às demandas emergentes do trabalho. Considerando que todos estão empregados em funções de comando, em escalas bem divergentes, reuni-los em um único horário foi uma tarefa complicada. Porém, a riqueza do conteúdo discutido pelos três participantes foi surpreendente. Segue abaixo a análise dos posicionamentos apresentados pelos tenentes nos trechos em que estes podem ser melhor inferidos, com base nos dilemas e questões propostas para o grupo.

\section{Trecho 1 (linhas 7 a 30)}

"PESQUISADORA: Pra começar eu vou apresentar uma situação pra vocês analisarem. (lendo a história). Qual é a tarefa de vocês? Colocar os seis personagens em ordem decrescente de culpa pela morte de Maria. Em 1ำ mais culpado e em 6으 o menos culpado pela morte de Maria.

SUZANA: Cada um dá uma resposta ou tem que ser em conjunto?

P: Gostaria de ouvir a opinião de todos, mas devem chegar a um consenso.

JONAS: Primeiro o marido.

$P$ : Por quê?

$\mathrm{J}$ : Porque ele afastou dela e não protegeu ela.

$P$ : Ele é o mais culpado?

S: Não, não concordo! Acho que é a própria Maria!

P: Por quê?

S: Porque ela descumpriu o contrato do casamento. Aí descumprindo o contrato do casamento ela se expôs ao risco que já existia.

GABRIEL: Ela tava tendo um caso com Paulo?

S: Tava!

$\mathrm{P}: \mathrm{Na}$ história diz que ela estava tendo um caso?

S: Não né? Mas se ela tava sozinha e ia procurar ele... Ela tava tendo um caso com Paulo... Porque Paulo... Paulo era amante senão não ia falar que ela conhecia um outro amigo.

G: Eu acho, assim, particularmente eu não vejo nenhum culpado.

P: Porque não?

G: Porque, olha só: não era função de nenhum deles dá proteção pra ela, a função era da Polícia! Ela tava pedindo proteção. Ela queria atravessar a ponte e foi procurar o amigo lá, 
que também falou: "Oh, isso não é problema meu..." E de fato não é!"

\section{Análise 1}

Esse trecho inicial mostra julgamento moral, especialmente por Suzana, de que Maria estava traindo o marido, que ela "descumpriu o contrato de casamento" e, portanto, seria a maior culpada por sua morte. Observamos aqui uma forte tendência conservadora que já nos sinaliza um valor constituído. Os colegas até questionam se realmente Maria estava tendo um caso com Paulo, mas ela é categórica na resposta: "Tava!". Gabriel traz uma reflexão interessante de que a função de dar proteção para Maria é da Polícia. Com essa visão preliminar, ele não considera nenhum dos personagens da história como culpado pela morte, e traz a responsabilidade para o agente de Segurança Pública.

\section{Trecho 2 (linhas 40 a 52)}

"J: Ela tava atrás de ajuda, de proteção, quem deveria dá proteção pra ela? Quem dá proteção pra mulher? Não é o marido?

P: Humm...

G: Mas ela pediu o apoio do marido? Aí que tá...

$\mathrm{J}$ : O marido sabia? Ele se interessou?

G: Ela pediu pro marido?

$\mathrm{J}$ : Aqui fala que ele se afastou dela, se afastou...

G: Como você quer culpar o marido? Você quer culpar o marido porque ele se afastou dela... Mas ela ligou pra ele? Ela falou "Amor, to aqui na ponte..." inventasse uma desculpa, "fui na casa da Joana e to precisando atravessar, tem como você vir aqui? Não? Ah, beleza..." Mas eu não vejo que o marido é culpado aí não...

S: Pra mim é por isso que a principal culpada é a Maria, porque ela vê um cenário de crime e mesmo assim peitou né? Passou ali mesmo sabendo que era inseguro né? Então né..."

\section{Análise 2}

Aqui observamos um valor apresentado por Jonas a respeito do papel de gênero no casamento: "Quem dá proteção pra mulher? Não é o marido?". Ele atribui a responsabilidade de proteger a mulher ao marido, e considera que o fato do marido ter se afastado de Maria contribui para sua morte. Por isso, atribui a ele uma parcela maior de culpa. Gabriel amplia a reflexão, considerando o marido inocente, pois ela não pediu a ajuda dele. E Suzana, por sua vez, reitera seu posicionamento de que Maria assumiu o risco pela própria morte. 
"G: Depois esse Paulo, porque esse Paulo também, vagabundo... "Não tenho nada a ver com isso não". Ué, não tem nada a ver! (indignação)

S: Ela assumiu o risco!

J: Então tá. Então foi a Maria!

G: Não Jonas, quem que é que foi o culpado então? Na sua opinião?

$\mathrm{J}$ : Nesse caso, se for analisar dessa forma, foi a Maria.

S: Porque ela assumiu o risco, viu o povo brigando lá e foi...

J: É... Ela insistiu na passagem...

S: Não tinha segurança...

G: O segundo é o Paulo, porque ela pediu pra ele. Falou assim "Paulo..." (risos)

J: Primeiro Maria e segundo Paulo. E o terceiro?

S: O amigo dela...

J: O terceiro é o Amigo, depois do Paulo ela foi procurar um Amigo. Pedir ajuda pra um Amigo!

G: Não, mas... Beleza! Mas esse Amigo também não tem culpa não...

(...) (linhas 87 a 91)

G: Como você quer culpar o amigo, Jonas, se ele tava com medo? (riso) Ele tava com medo, ele se acovardou diante da presença dos bandidos... Ele não teve coragem de enfrentar, ele ficou com medo, falou assim: "vamos morrer nós dois" Uai... Pensa você, Jonas, a pessoa vai te chamar pra ir ajudar a numa parada ali:" vou não, Stive ${ }^{7}$, vai dar merda, vai morrer nós dois..." E aí? Que culpa ele tem? Não é verdade?"

\section{Análise 3}

Observamos julgamento moral por parte do Gabriel que considera Paulo como "vagabundo" por ter se eximido da responsabilidade de ajudar Maria. O participante expressa indignação com a fala contida na história, atribuindo a ele o segundo lugar no escalonamento de culpa. Podemos, também, observar nesse trecho uma espécie de persuasão implícita do grupo sobre Jonas, quando este expressa uma fala conformista "Então tá. Então foi a Maria!". Logo em seguida, é questionado por Gabriel e instigado a se posicionar. Mas responde a partir da linha de raciocínio estabelecida pelo grupo, demonstrando certa fragilidade em estabelecer um posicionamento próprio. A discussão flui e chega a um ponto interessante onde $o$ posicionamento do Amigo é questionado. Suzana e Jonas acham que ele deveria ser o terceiro mais culpado, mas Gabriel defende que o fato dele ter expressado medo de também ser morto diante da situação legitima seu recuo, isentando-o de culpa. Essa discussão será retomada pelo grupo no trecho 5 .

\footnotetext{
${ }^{7}$ Forma usual de tratamento entre os policiais militares do Estado X.
} 


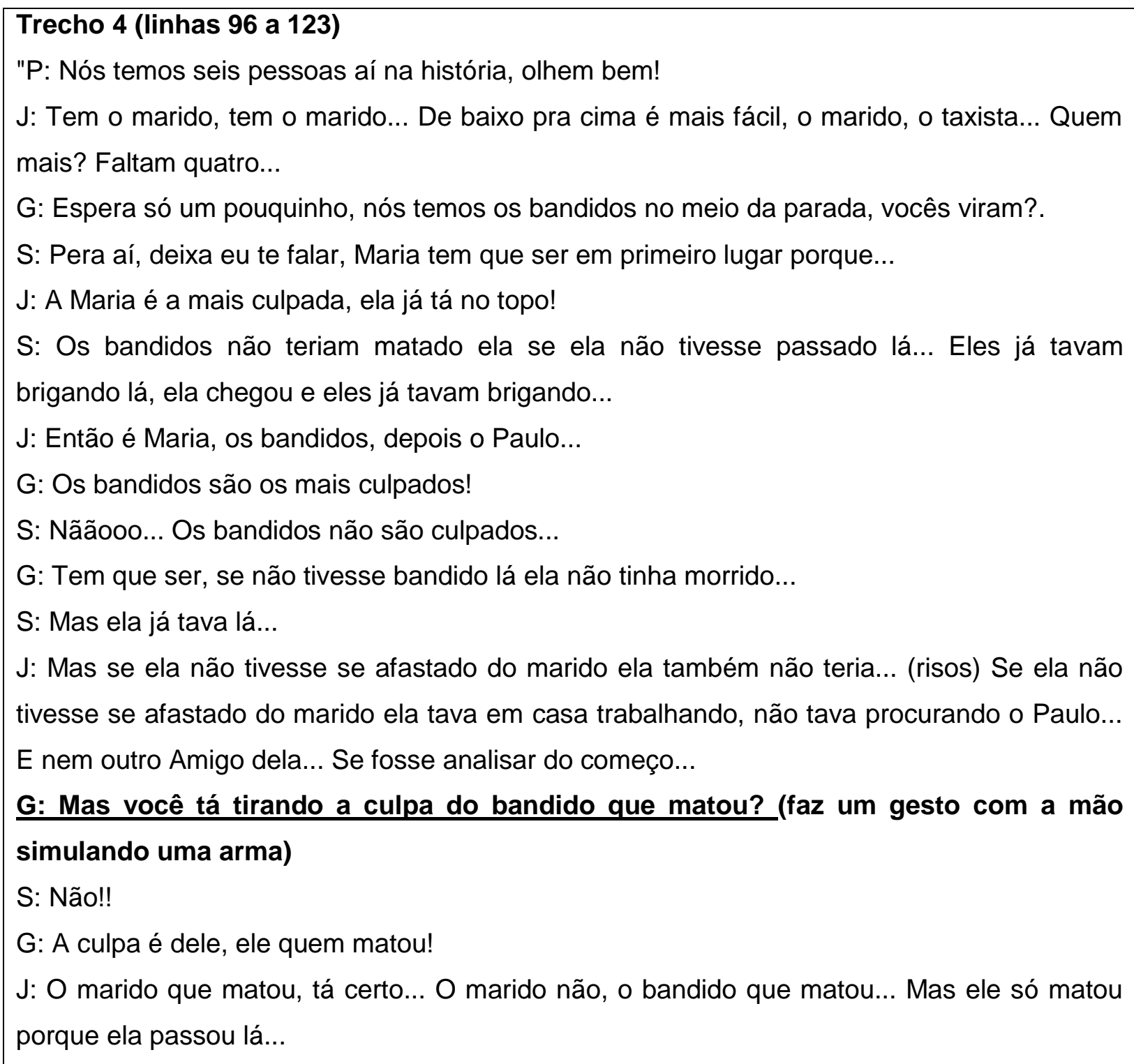

G: Mas isso que eu quero que você entenda, a culpa, a primeira culpa é do bandido que matou! Gente, que é isso? Vocês estão querendo tirar a culpa do assassino? A culpa é dele! Se ele não quisesse matar ela "não vou matar você, pode passar..." A culpa foi dele!

J: Não, acho que primeiro foi a Maria e depois o bandido... (risos). Vamos lá, é um conjunto... G: A primeira culpa é do bandido!"

\section{Análise 4}

Esse foi o momento ápice da discussão do grupo, onde a culpa dos bandidos é trazida à tona e de uma forma muito enfática, por Gabriel: "Os bandidos são os mais culpados!" e Suzana faz o contraponto: "Nããooo... Os bandidos não são culpados...". Gabriel insiste veementemente na questão chamando seus colegas à reflexão: "Gente, que é isso? Vocês estão querendo tirar a culpa do assassino?". Até este momento as discussões foram amplas, 
envolvendo julgamento moral, expressão de valores construídos e posicionamentos a história. No entanto, a partir desse "insight" um tanto tardio por parte de Gabriel, ao qual os colegas resistem; Suzana de maneira enfática e Jonas dizendo que "... Mas ele só matou porque ela passou lá...", o grupo passa a considerar a responsabilidade do bandido quanto ao crime cometido! Surpreende, assim, que apenas nesta altura da discussão os bandidos sejam vistos coo responsáveis pela morte da mulher. Até então, na visão dos participantes, a culpa era da vítima e daqueles a quem pediu ou não ajuda...Essa discussão será retomada no trecho 6.

\section{Trecho 5 (linhas 152 a 165)}

"G: A minha ordem de baixo pra cima é... Pra mim o amigo, depois o taxista, depois o marido, depois ela né? O primeiro é o bandido!

S: Deixa eu te falar, se realmente fosse amigo ele não ia falar assim: "não posso te ajudar, se vira!" Amigo não é pra comemorar churrasco não...

G: Mas mesmo assim...

S: Amigo é pra ajudar! O que ele poderia ter feito? Esse amigo, ele poderia ter falado assim: "Maria mantenha calma..."

G: (gargalhada) Mantenha calma...

S: Função de amigo é isso... "Não vai agora, você sabe que você vai morrer, você quer assinar seu atestado de óbito?"

G: Mas ele falou...

S: Não, ele falou assim: "se vira..."

$\mathrm{J}$ : Ele se acovardou, o amigo é o acovardado!

S: Se ele era covarde, se ele não teve coragem pra ele, ele devia ter alertado ela..."

\section{Análise 5}

Nesse trecho constatamos o que Suzana compreende como amizade. Ela defende veementemente que o Amigo tem muita culpa na morte de Maria por não tê-la impedido de seguir o caminho. Por mais que os colegas tentem argumentar que o Amigo estava com medo, ela considera que seu posicionamento diante do fato foi reprovável e por isso ele deve ocupar um local mais elevado no escalonamento de culpa.

\section{Trecho 6 (linhas 239 a 258)}

"S: Gente, gente, pera aí... Se a gente for realmente... Que a gente tá pensando como... Tá pensando como... Óh... (risos)

J: Vamos lá, vamos lá... 


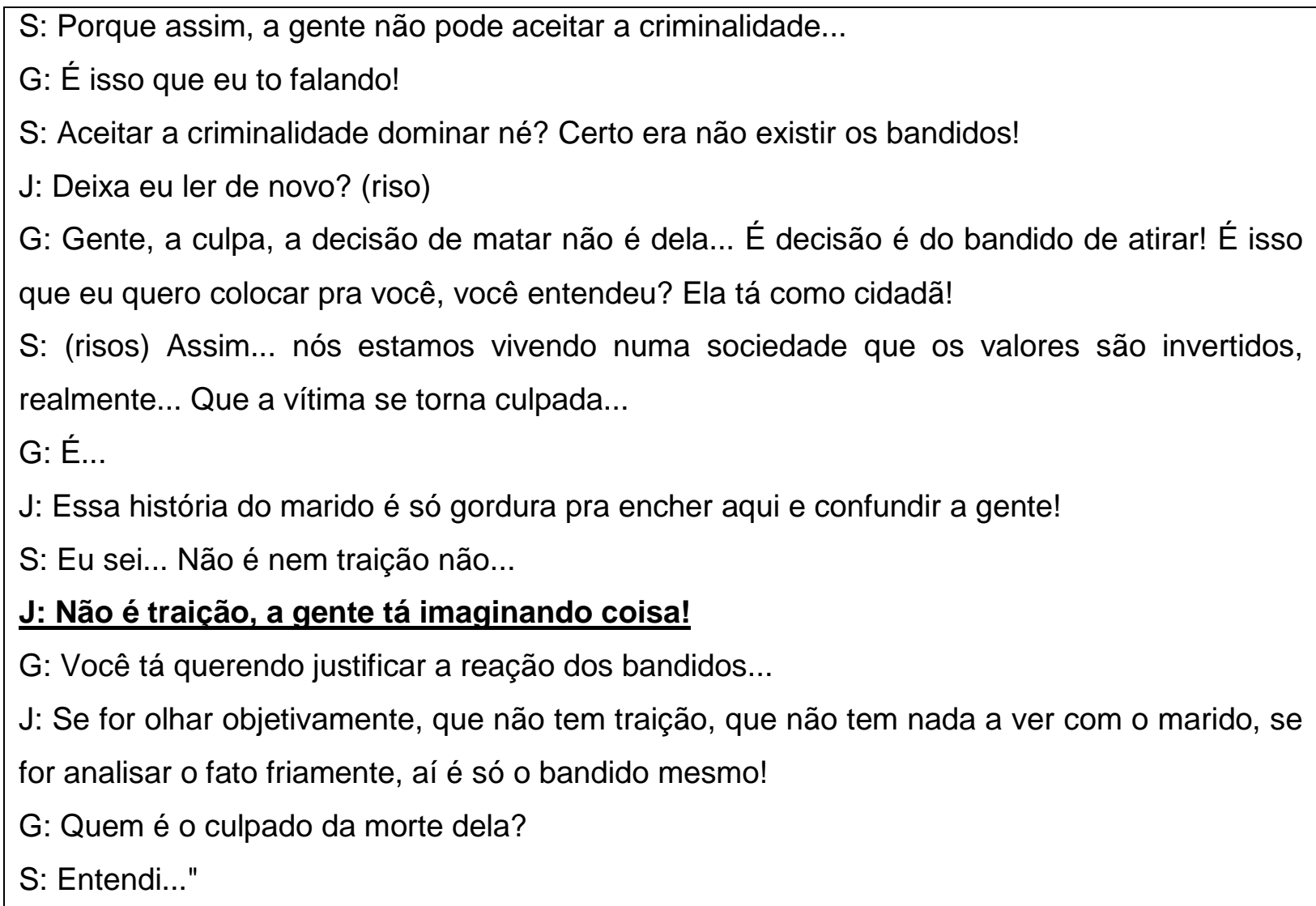

\section{Análise 6}

Nesse trecho a discussão sobre a culpa dos bandidos é retomada, após o "insight", desta vez de Suzana, com relação à culpa dos bandidos. Gabriel reitera, para o grupo, sua convicção da culpa dos bandidos. Suzana apresenta um posicionamento diferente do anterior, assumindo que havia feito uma análise equivocada que precisaria ser revista: "Assim... nós estamos vivendo numa sociedade que os valores são invertidos, realmente... Que a vítima se torna culpada...". Jonas também revisa seu posicionamento, e resume o grande equívoco de todos eles na atribuição de responsabilidade pelo assassinato: "Se for olhar objetivamente, que não tem traição, que não tem nada a ver com o marido, se for analisar o fato friamente, aí é só o bandido mesmo!". É interessante observar como a dinâmica da discussão do grupo foi modificada após Gabriel trazer para o grupo a perspectiva crítica da ocorrência e da responsabilidade pelo crime, mudando seu posicionamento e isentando a vítima e os demais da culpa, levando os colegas a também reverem seus posicionamentos, até que todos destaquem a centralidade do papel dos bandidos no crime cometido. Os risos demonstram a surpresa dos participantes ao perceberem o quanto se enganaram inicialmente ao não pontuarem a culpa dos bandidos.

Trecho 7 (linhas 430 a 441)

"S: Vocês vencem porque são maioria, mas a minha opinião é que ele... 


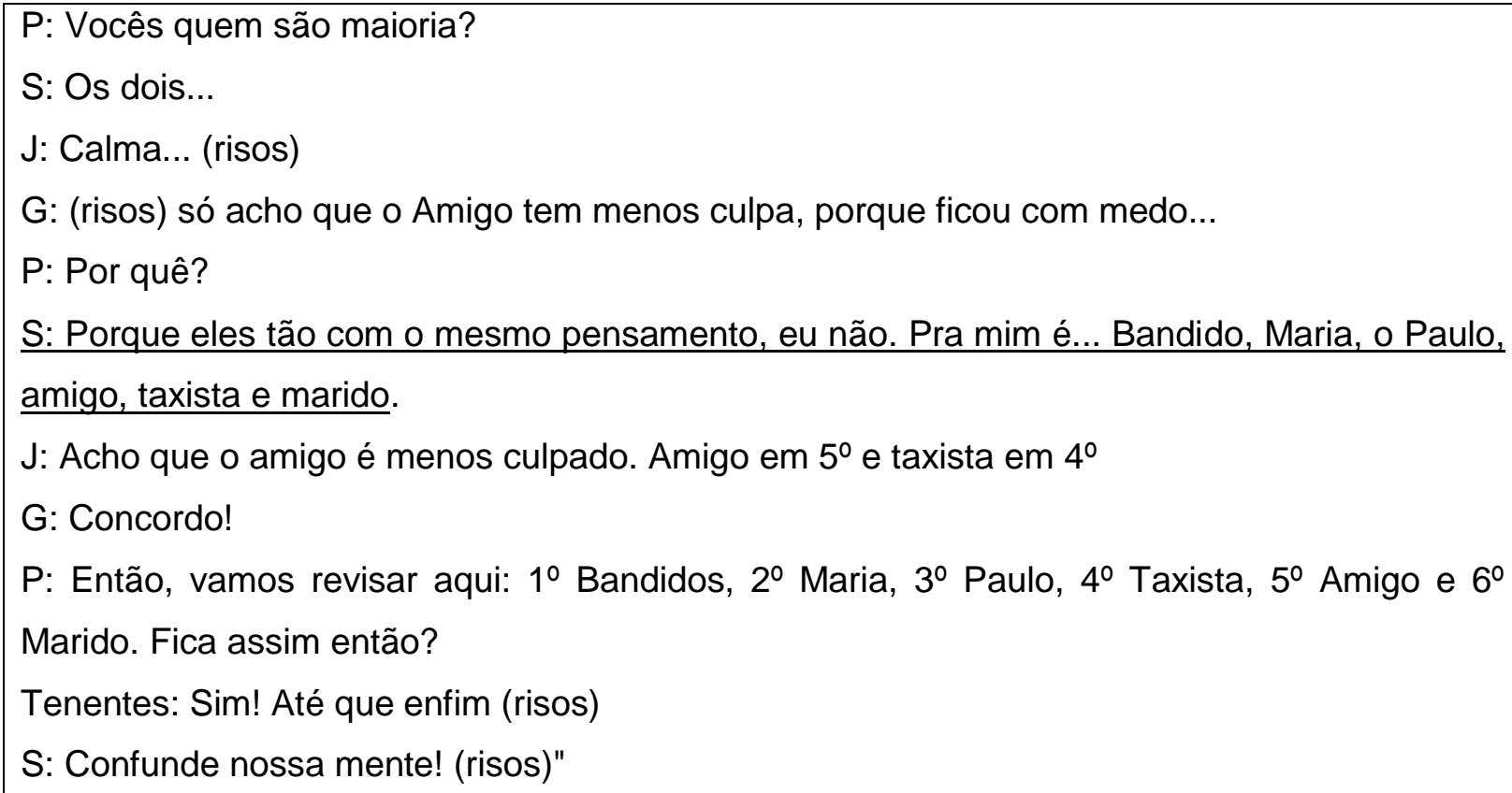

\section{Análise 7}

A discussão nesse trecho foi a respeito do posicionamento que ocupariam Amigo e Taxista no escalonamento de culpa. Vale ressaltar a fala de Suzana: "Vocês vencem porque são maioria". Podemos observar que para Suzana, o amigo seria mais culpado porque, em sua visão, ele não cumpriu o seu papel de "amigo" ao não ajudar Maria de alguma maneira. Gabriel e Jonas não se intimidaram com a "reclamação" da colega e mantiveram seus posicionamentos. Além disso, Suzana destaca, ao dizer que "Confunde nossa mente!", o quanto os participantes tiveram dificuldade em superar a tendência de culpar a vítima, naturalizando, assim, o crime e a violência, e julgando o valor "moral" da conduta das vítimas.

\section{Trecho 8 (linhas 442 a 446 / 501 a 517)}

"P: Vamos para a segunda situação, pra vocês analisarem. "A Bomba e o Policial" (Lendo a história)

J: É... A gente não pode dizer isso! (risos)

S: Corta! (risos)

$\mathrm{J}$ : A gente consegue, mas...

$(\ldots)$

J: A gente colabora na prisão dele, uma delação premiada, alguma coisa assim... (risinho)

G: Ele já tem vários históricos né?

P: Sim

S: Ah gente! Não tem isso de 'matar milhares de pessoas...' Isso é legalista, é a lei, então a 
lei que manda!

J: A gente trabalha com recompensa... Dá recompensa pra ele, "Oh, se você falar aonde tá..."

S: Cai nessa não! É legalidade, é a lei! Se ele não falar problema dele!

G: E deixa explodir tudo? Não... Não... Eu acho que tem uma inversão de valores aí... O prósocietário... Garantia da segurança da sociedade, da ordem pública que predomina sobre o direito individual dele! Pra mim tem que ser assim, como é nos Estados Unidos lá... Como eles tratam os terroristas lá? Os suspeitos de terrorismo? Justamente, há uma inversão... No caso especifico de terrorismo, é o pró-societário, ele perde as garantias individuais...

S: Gabriel, eu sei. A lei, a lei ela é imoral! Totalmente imoral, a gente sabe disso! Tem a moral e a ética. Ela é imoral né? A ponto dela falar assim: "prende e pronto". Só que a gente sabe que não é assim na prática!"

\section{Análise 8}

Esse segundo dilema começa a ser discutido de forma descontraída, demonstrando que não poderiam expressar seus métodos de obter a informação do suposto terrorista da história. Logo em seguida, observamos uma defesa bem pontual da "legalidade", por parte de Suzana. Jonas propõe negociações com o assassino, delação premiada para tentar obter a informação. Gabriel, por sua vez, manifesta-se contrariamente a esses posicionamentos, argumentando que no caso em questão deve-se pensar em prol da sociedade, protegendo a vida das milhares de pessoas ameaçadas pela bomba. Posicionamentos inicias bem distintos para o mesmo dilema. Mas vale aqui salientar as palavras de Suzana ao dizer "A lei, a lei ela é imoral! Totalmente imoral, a gente sabe disso!". Essa fala é muito utilizada no meio policial, para expressar sua indignação quanto à questões que a Lei permite, mas eles não consideram correto e por isso dizem que é "imoral".

\section{Trecho 9 (linhas 526 a 549)}

"G: A senhora quer uma resposta?

\section{S: Ela quer cair na tortura!}

G: Não...

P: Não, não quero cair na tortura, quero saber se existe um limite nessa situação e qual seria?

G: Limiar... se conversar... Conversa sem ter agressão... Numa conversa...

S: Tem tortura psicológica, essa conversa já enquadra como uma tortura psicológica! Vai ferrar do mesmo jeito... Porque ele tá subjugado, ele tá preso... Já tá sob seu domínio, já configura o artigo da tortura lá, sob sua guarda. Qualquer coisa que você 
falar ali, mesmo que você não tocou na mão dele, mas torturou psicologicamente...

G: Pela sociedade... A resposta é pela sociedade ou particularmente?

S: Pela sociedade a gente vai fazer ele falar, vai fazer ele falar...

G: Pela sociedade, pela visão particular acho que seria assim, ele deveria falar né? Não importa o meio. É uma situação. Agora profissionalmente falando, tendo em vista todo o ordenamento jurídico da sociedade, é fazer nada...

J: Prender ele... E se achar que ele tá blefando? BUM, explodiu!

G: Aí ele vai responder por um crime...

S: É isso que acontece com o policial hoje. Ele se vê de mãos e pés atados por quê? Se ele faz a justiça e ele põe a vida dele em risco... Ele que vai responder depois, por tortura... Assim como na Operação X e outras operações que tem aí. Quando o policial quer fazer alguma justiça né? Extrapolar a legalidade, pra poder fazer justiça, é a hora que ele se arrebenta, arrebenta a família dele!

G: Nossa prevencão teria que ter ficado no momento em que ele tava colocando a bomba em outro lugar! A partir do momento que ele colocou e já saiu e foi preso... A nossa prevenção falhou!"

\section{Análise 9}

Nesse trecho Gabriel expressa dúvidas, e Suzana sugere que a pesquisadora "Quer cair na tortura!". A questão é novamente explicada e a participante fala sobre a 'tortura psicológica', que já seria configurada como crime. Ela traz também uma reflexão interessante sobre a atuação do policial, afirmando que quando ele "extrapola a legalidade" e quer fazer justiça "ele se arrebenta". Essa é uma fala comum entre os policiais, quando se trata de situações dilemáticas como essa, na qual ele se sente dividido entre o que a Lei manda, ou permite, e o que ele acha correto fazer. Gabriel explica seu posicionamento: haveria uma 'visão social' e outra 'particular' sobre o fato, mas ainda demonstra dúvidas. No final, afirma que o trabalho preventivo da PM apresentou falhas, uma vez que não conseguiram evitar o crime. Jonas não se posiciona de forma clara. Nesse segundo dilema, houve menos discussão, com posicionamentos mais fluentes e inseguros. Essa discussão foi menos acirrada, sugerindo o grave caráter dilemático da situação, explicitado com veemência apenas por Suzana, e colocado por Gabriel como "Pela sociedade, pela visão particular acho que seria assim, ele deveria falar né? Não importa o meio. É uma situação. Agora profissionalmente falando, tendo em vista todo o ordenamento jurídico da sociedade, é fazer nada...". Suzana, ao dizer que "É isso que acontece com o policial hoje. Ele se vê de mãos e pés atados por quê? Se ele faz a justiça e ele põe a vida dele em risco... Ele que vai responder depois, por tortura... (...) Quando o policial quer fazer alguma justiça, né? Extrapolar a legalidade, pra poder fazer 
justiça, é a hora que ele se arrebenta, arrebenta a família dele!". É como se não fosse possível resolver a questão, uma situação sem solução.

\section{Trecho 10 (linhas 562 a 591)}

"P: Agora tem algumas questões que eu vou trazer a respeito do CFO e gostaria de ouvir opinião de vocês. Vocês saíram há pouco tempo da APM... Durante a experiência de vocês aqui, quais as práticas e regras vocês acreditam que mais os ajudaram na formação como oficiais?

G: Eu vejo o... O relacionamento mesmo!

$\mathrm{J}$ : Disciplina dentro do quartel!

G: Disciplina, o relacionamento da própria... O convívio aqui... Esse clima aqui que deu, deu uma base pra... Muitas pessoas que ás vezes, por exemplo, eram tímidas.

J: Até as dificuldades eram superadas... Todos nós não sabíamos como funcionava o quartel, como que era o militarismo...

G: Não só isso, mas eu falo... Às vezes até na oratória...

$\mathrm{J}: \mathrm{Sim}$.

G: Às vezes num relacionamento que você tem que enfrentar problemas conturbados, você consegue... Lá fora às vezes, ser mais articulador, ter mais jogo de cintura.

S: Quem já era, continua! (risos) Você sempre foi assim... (fala para Gabriel)

G: Nasci assim... (risos)

P: Ok, mas tem alguma regra ou norma mais específica? Ou alguma instrução que tenha contribuído de forma mais focal?

S: As aulas práticas ajudaram bastante! $A$ aula prática também, quando a gente se sentiu bem assim... Mais realmente preparado, foi quando a gente começou a sair pra rua realmente, no estágio.

$\mathrm{J}$ : Eu, particularmente, esse negócio de entrar em forma. Assim, no começo eu achava uma coisa um pouco assim, excessiva! Mas eu vejo na rua... Por exemplo, eu entro no serviço e muitas pessoas demoram a entrar no serviç, demoram pra se equipar, demoram pra entrar numa viatura, enquanto isso eu tenho um números de roubos... Posso ter 10 roubos em uma hora!

G: Sabe no que o Jonas quer traduzir isso? Disciplina! Às vezes falta!

J: É... Disciplina!

$\mathrm{J}$ : Na rua isso faz uma diferença muito grande!" 


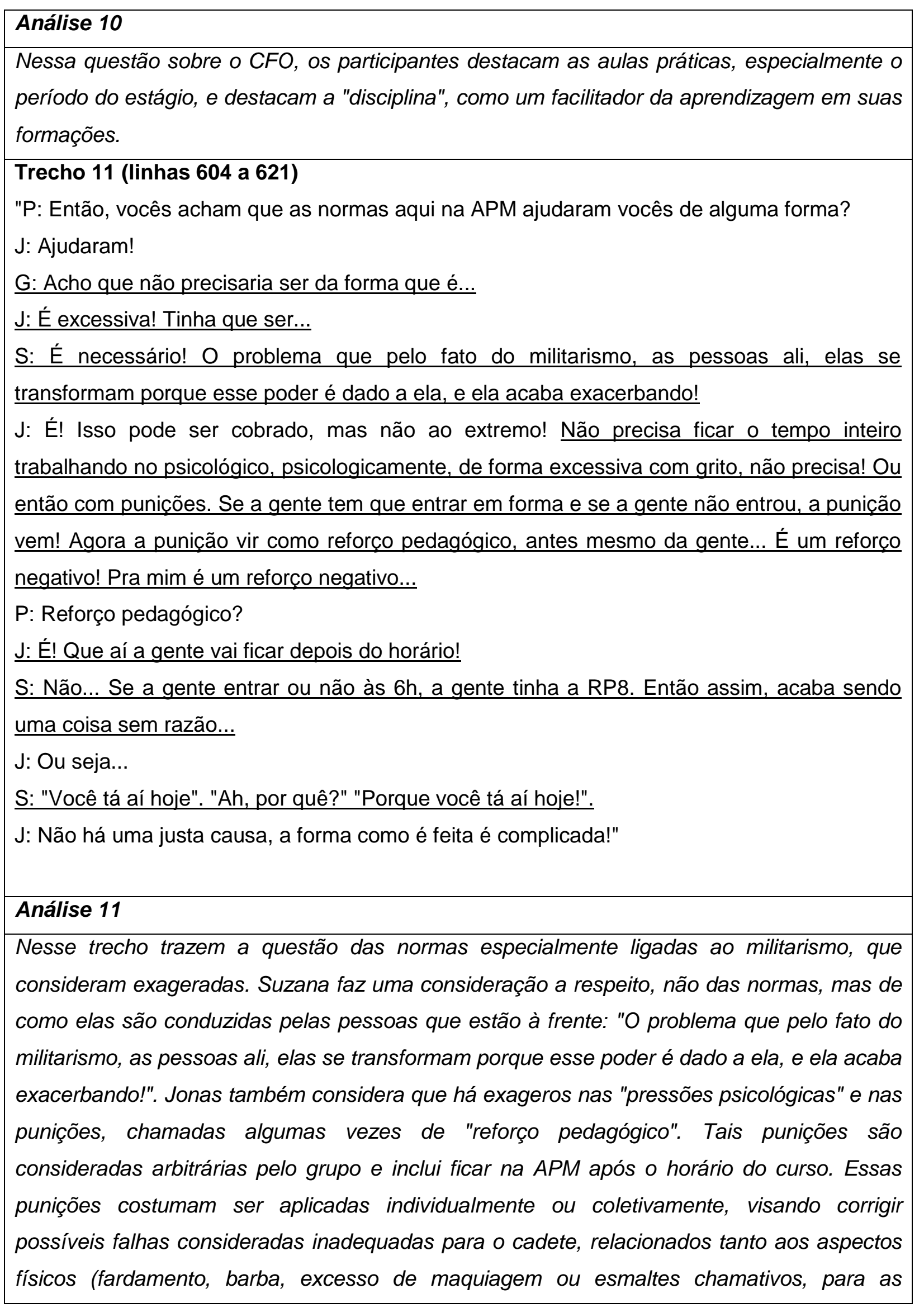


mulheres) quanto aos comportamentais (marchar, forma de se apresentar a um superior ou se portar no pátio). O interessante é que as normas quase nunca se referem a questões pedagógicas, que envolvam o processo de aprendizagem do aluno. Talvez, por isso, eles considerem como exageradas e desproporcionais.

\section{Trecho 12 (linhas 622 a 658)}

"P: O que isso causou em vocês? Qual o sentimento?

J: Eu criei antipatia! Pelo excesso de rigor! Eu olho pelo lado assim, elas são necessárias... Esse ordenamento nosso, ele é necessário, mas tem que ser melhorado! E a forma como ele é cobrado tem que ser renovada!

P: Uhum...

J: Mas, é... A forma que eu fui adestrado, vamos falar assim, aqui dentro... Eu não faria com outras pessoas! Eu não faria! Faria de outra forma é... Como, baseada nos Direitos Humanos, baseada na conversa, baseada na explicação... $\mathrm{Na}$ negociação... Entendeu? Totalmente diferente!

$P:$ E vocês?

S: Eu falo... Eu concordo com ele. Eu cobraria de outra forma! Não cobraria do jeito que fui cobrada.

P: E o sentimento?

S: Eu já tinha essa paixão pelo militarismo desde a minha infância, então pra mim não fez acabar essa paixão. Porém, criam certas aversões! Não contra o militarismo, igual eu falei pra senhora, contra a pessoa que tá usando aquilo ali né?

$P:$ Naquele momento?

S: Naquele momento especifico não! Pra muitos, a vida inteira, a pessoa vai ser tachado negativamente!

P: Humm...

G: Cria mesmo... uma paixão! Mas existem outras coisas que desestimulam você. Não é o militarismo em si que desestimula...

$\mathrm{S}$ : O militarismo é bom!

G: O militarismo é muito bom! O problema são as outras coisas. Aí vem salário, vem carga horária, e uma série de coisas. Não é problema do militarismo... E pra eu falar pra senhora que o militarismo me desmotiva? Não, o militarismo não me desmotiva. O que me desmotiva são os outros fatores! Carga horária excessiva, é... Pessoal, salário, e daí segue relação. $\underline{Q u e ~ e m ~ o u t r a s ~ p r o f i s s o ̃ e s ~ v o c e ̂ ~ o l h a ~ e ~ c o n s e g u e ~ e s t r u t u r a, ~ c o n s e g u e ~ v i s u a l i z a r . ~}$ P: Ummm...

G: O militarismo, ele é desejado... Por exemplo, eu tenho parentes da policia civil e da policia 
federal! Eles veem o militarismo como... Uma vantagem pra gente, e de fato é! Uma coisa assim... a gente tem a hierarquia né? É... Qualquer instituição quer isso, ter hierarquia, mas as outras coisas são os outros fatores!

S: É assim, tem o militar, o oficial né? O instrutor... Nossa, o padrão do cara é excelente! Ele tem domínio do conhecimento, ele tem a didática. E ele sabe fazer o controle do uso do militarismo. A pessoa às vezes pode ser ralado por ele num curso, por exemplo, mas vai amar aquela pessoa, vai admirar!"

\section{Análise 12}

Esse trecho traz expressões importantes de como as significações da formação foram construídas pelos tenentes. Jonas apresenta um termo muito utilizado no militarismo quando diz "A forma que eu fui 'adestrado', vamos falar assim, aqui dentro... Eu não faria com outras pessoas!". Apresenta um posicionamento muito carregado de convicção sobre esta forma de "adestramento", com a qual ele não concorda e não replicaria em sua prática. Este termo, bem como o termo "forjado" é muito utilizado nos contextos militares para se referir à formação. Eles tem uma conotação negativa, pois deixam subtendido que processo formativo tem apenas uma via, a da rigidez e da coerção, desconsiderando a subjetividade do aluno. Gabriel e Suzana consideram o militarismo como "bom", falam sobre suas "paixões" pelo regime, mas ampliam suas reflexões sobre a vivência deste no ambiente da APM. Assim como na análise anterior, é unânime entre os participantes a crítica quanto à forma e os excessos cometidos no ambiente da APM, considerados desnecessários para o processo formativo.

\section{Trecho 13 (linhas 669 a 688)}

"P: Ok. Continuando nessa temática, os rituais e solenidades que vocês tinham, especialmente na época do CFO, o que vocês acham deles?

G: Eu, particularmente gostava!

\section{S: Eu também! Eu sou apaixonada!}

G: Eu, essa... Eu sempre me via desfilando... Tem gente que não gosta... Eu vou falar a minha opinião... A solenidade... Então, por exemplo, quarta-feira tem solenidade, vou e vou com todo o prazer, vou desfilar! Eu particularmente gosto...

S: Eu sou apaixonada por essas coisas! Eu arrepio sempre! O Hino Nacional me emotiva. G: O problema é quando você faz todo dia, todo dia, todo dia... É o que te cansa! Então a gente fazia todos os dias...

S: O que acontece aí, deixa eu te falar...

J: Todo dia! Eu lembro! 


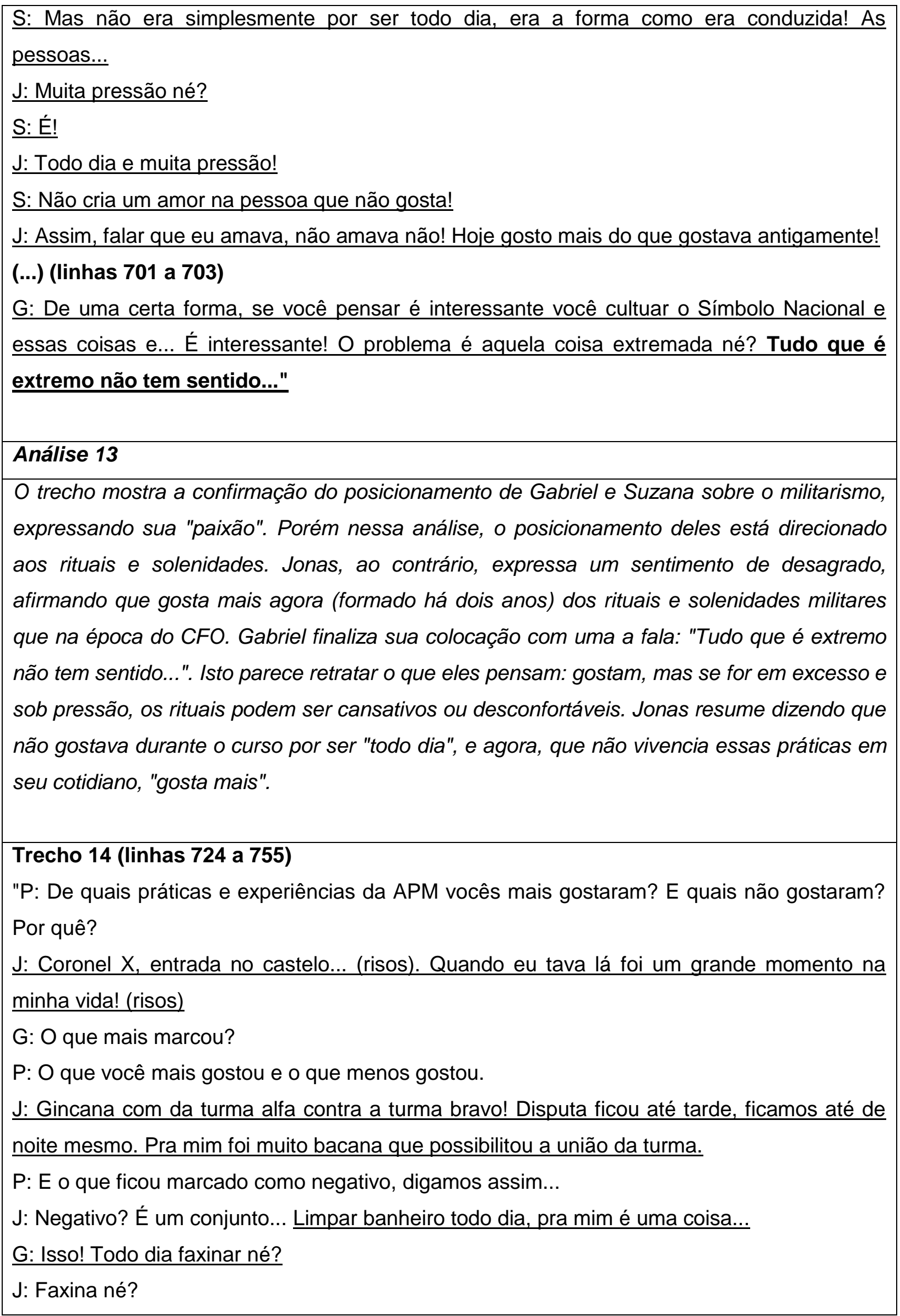


G: Pô, acho que o corridão que a gente fez aí com o pessoal das especializadas... E é uma coisa que motiva o grupo e tal... A gente fez isso de vez em quando.

S: O que eu gostei muito foi a jornada de campo que a gente fez lá CFAP9. Foi muito bom, isso é fato! Gostei!

J: Foi muito bom!

$P$ : E o que menos gostou?

G: Faxina!

S: Pra mim não é faxina não, porque eu faxino minha casa desde pequena, isso aí pra mim é sem novidade e eu já to acostumada. (riso) Agora o problema que eu sempre falo e friso é a pessoa saber utilizar o militarismo. É isso que me estressa!

G: O maior problema, vou falar pra senhora, são duas coisas que me estressou. Assim, que eu ficava estressado no CFO. Olhar o companheiro como adversário!

S: Isso!

G: Essa é uma das situações. Nós nossos amigos, mas ao mesmo tempo que nós somos amigos, nós somos adversários porque vale nota e futuramente vai ter uma classificação.

Então assim, isso pra mim é terrível! Competir 24 horas com o seu colega.

P: Vocês acham que isso é cultivado aqui dentro da APM?

S: Sim, isso daí é o mais valorizado: ser o zero um e zero dois. Isso aí é a farsa! É uma falsidade! A pessoa prega companheirismo, amizade, ao mesmo tempo em que aqui... Igual eu mesma, eu fui jogada pro ultimo, pra rela."

\section{(...) (linhas 761 a 776)}

"S: Fiquei de segunda época, beleza! Aí tipo assim, é isso aqui que prega? A gente se sente ridicularizado! O instrutor chega na sala e fala: "a galera do fundão ali, são os últimos colocados da rela!".

$\mathrm{P}$ : Os lugares na sala foram dispostos por colocação?

S: Foi! Então assim, capitã, não to falando que pra mim é situação de humilhação, mas que o povo aqui valoriza demais a colocação.

J: É desgastante!

S: É desgastante!

G: Isso mentalmente é... Desgasta né? Outra coisa, o relacionamento, principalmente do CFO mais antigo com o mais moderno! É uma coisa que eu acho que deveria... Sabe? Somos todos oficiais, vamos ser oficiais no futuro, acho que deveria, sabe? Acho que deveria ser um relacionamento de mais respeito...

J: Mútuo!

G: Onde deveria ser cativado... "Olha, nós vamos ser tenentes juntos, como oficiais, que será

9 Centro de Formação e Aperfeiçoamento de Praças, da Polícia Militar. 
uma amizade futuramente né? Mas, ó, nós estamos aqui como seu superior temporariamente..." Porém não é assim, é um relacionando muito... Desgastado!"

\section{Análise 14}

As opiniões, nesse trecho, convergiram para práticas divertidas: Jonas citou uma dinâmica realizada em sala durante uma aula de Psicologia, Gabriel destacou o corridão, Suzana apreciou a jornada de campo. Jonas menos gostou as faxinas. Gabriel e Suzana não gostavam da competição entre os cadetes pela colocação no curso, Gabriel criticando, especialmente, o difícil e desgastante relacionamento do CFO mais antigo com a turma deles10. Suzana disse ficar "desgastada" (termo utilizado por todos) com a forma como o militarismo é utilizado, com excesso de autoritarismo e com a prática de humilhações. Ela evita empregar este termo, mas seu significado pode ser claramente inferido de sua fala quando diz que ela tinha que sentar no fundo da sala devido à sua colocação no curso ("A gente se sente ridicularizado!'). O excesso de competição na formação militar é criticado, e colocado com clareza por Gabriel: “(...) eu ficava estressado no CFO. Olhar companheiro como adversário!". A classificação obtida no curso define a ascensão na carreira, a posição alcançada no CFO vai direcionar todos os passos do oficial, e isto cria uma grande contradição entre companheirismo e competição entre os cadetes. Segundo Suzana, "Isso aí é a farsa! É uma falsidade! A pessoa prega companheirismo, amizade, ao mesmo tempo em que aqui...". Na análise do grupo, essa forma de avaliação prejudica o relacionamento entre os colegas não só durante o curso, mas também após e, em alguns casos, por toda a vida do oficial. O tema qualidade do relacionamento é também sublinhado por Gabriel, que se queixa da falta de respeito entre os CFO mais antigos e os mais modernos: "(...) é um relacionando muito... Desgastado!".

\section{Trecho 15 (linhas 779 a 827)}

"P: E o que vocês acham que é mais importante pra formação de um oficial? (pausa grande)

J: O equilíbrio... Entre saber formar oficiais, saber comandar uma tropa, saber que você é um líder, e também saber fazer...

G: Maior desafio?

J: É... Maior desafio...

G: Lideranca!

S: Liderança! Que a liderança não pode ser confundida com chefia... Que é o que mais acontece! 
J: Você administrar uma policia... Hoje você é um chefe de pelotão, amanhã você é um Comandante Geral... Isso você tem que ter um jogo de cintura muito grande. Ter uma habilidade muito grande com pessoas e também com o que move a PM.

S: E no CFO a gente era tratado justamente pra não ser líder, né?

G: Na verdade... Eu falo isso com transparência, é uma responsabilidade que é dada pra gente muito novo. Eu me vejo novo, e é uma responsabilidade que é colocada nos seus ombros... Você cuidar de pessoas que é pai de família...

S: Mais velha que a gente...

G: Mais velha... É uma responsabilidade com o quartel... Eu tenho sob meu comando lá mais de 100 policiais, meu efetivo é 163.

S: Essa função de comando, comando mesmo no CFO, você vai ver nos últimos dias. Em três anos de curso, você vê nos últimos dias...

G: $\mathrm{E}$ o tenente é que tá a frente, tem essa responsabilidade de carregar nas costas a administração, o serviço, tudo! É o que é o desafio, formar esse oficial né? Centrado... O cara te chegar com um problema, te trazer um problema e você dar a solução pra ele... $\mathrm{E}$ tudo vai desaguar no tenente, que é o responsável por tudo, que é o chefe imediato.

P: O mais importante então, na formação, na opinião de vocês seria?

S: Liderança! Porque a gente fica os três anos ralando sem autonomia. A gente não tem autonomia! Ainda mais se tiver uma turma mais antiga. Aí a gente sai daqui com a cabeça de praça, de execução..."

\section{Análise 15}

A questão suscitada nesse trecho faz o grupo refletir, já que demoram mais que o comum para emitirem suas opiniões. Consideram como mais importante na formação do oficial o equilíbrio e a liderança. Em suas reflexões avaliam as demandas que encontram em suas práticas na função de comando e consideram como uma responsabilidade cuidar de seus subordinados, das questões que surgem em serviço. Também levantam a questão de formar um oficial equilibrado, centrado que pode comandar um pelotão pequeno ou toda a corporação. Na avaliação de Suzana, porém, se destaca o fato de que durante o curso eles aprendem apenas a obedecer, o que dificulta a formação do oficial enquanto líder: "no CFO a gente era tratado justamente pra não ser líder, né?", "a gente fica os três anos ralando sem autonomia. A gente não tem autonomia! Ainda mais se tiver uma turma mais antiga. Aí a gente sai daqui com a cabeça de praça, de execução..." e, ainda, "Essa função de comando, comando mesmo no CFO, você vai ver nos últimos dias. Em três anos de curso, você vê nos últimos dias...". Quanto a isso, Jonas e Gabriel discordam da colega, como veremos a seguir. 
Trecho 16 (linhas 945 a 960)

"P: Pra finalizar nossa conversa, na opinião de vocês, o CFO proporcionou uma boa base pra vocês? Vocês consideram que saíram bem formados da APM? Ou foi a atividade prática de vocês lá nas unidades, que deram a maior contribuição?

J: Eu achei que fui bem formado!

G: Eu também achei!

$\mathrm{J}$ : Eu achei que fui bem formado porque tive uma base muito boa, tive um conhecimento assim... Não era meu sonho aqui dentro, nunca quis ser cadete. Por outros motivos... Mas assim, pelo que eu vi, pelo que eu pude sentir, eu tive uma base muito boa! Hoje eu sou... Eu vejo a policia de outra forma, como gestor! Você consegue ver todas as nuances, as dificuldades. A prática é um complemento, óbvio! Mas o que eu vejo na prática eu já estudava aqui dentro da APM. Meu principal embasamento foi aqui! Lógico, ela tem que melhorar em alguns aspectos... Sempre pode melhorar!

G: Na verdade a gente vê que o problema não é tanto aqui dentro, o problema é fora! A parte de fora! O que ensina é legal, é bom, planejamento, muito bom! Mas e lá fora né? A policia em si, como que... Ela tem que te dar instrumento pra você trabalhar..."

(...) (linhas 968 a 970)

"G: Nós sabemos fazer, eu sei trabalhar, na minha unidade eu sei resolver todos os problemas! Eu quero resolver, mas o que falta às vezes são os recursos, instrumentos, os meios... A gente tem que ficar sempre no "se vira!""

\section{(...) (linhas 996 a 1012)}

"S: Pra mim a formação... ela é um pouco precária! Precisa de um planejamento atualizado, da realidade que nós vivemos hoje, um estudo da sociedade. E direcionar esse policial pra esse problema. Não é manter um CFO de antigamente! Que a sociedade era outra, que os anseios, os problemas eram outros. Que a marginalidade tinha outros modus operandis.

G: Mas melhorou...

S: Melhorou, mas só porque melhorou tem que permanecer assim? Não... tem que planejar mais, porque a sociedade e a tecnologia tá sempre em movimento, a gente não pode ficar estagnado como a policia sempre fica estagnada!

G: O CFO deixou acho que a experiência, assim... Trouxe a realidade e assim, criou a responsabilidade que a gente tem com as coisas, com a vida né? Trouxe uma forma diferente da gente olhar as... É... E saber lidar melhor com as dificuldades, com as crises... A gestão de pessoas também... Acho que isso que trouxe, até mesmo com a disciplina, a valorização aos rituais, a nacionalidade... Os rituais que antes como civil a gente não tinha né? Achei importante! O respeito (enfatiza), o respeito com o próximo, tanto que foi o que a gente... Por tantas vezes a gente foi desrespeitado, a gente aprende como não fazer. Não 
vou fazer assim, vou ter respeito com o próximo, vou tratar ele bem, pra chamar a atenção..."

\section{Análise 16}

O trecho final do grupo focal revela certa disparidade quanto ao posicionamento dos participantes em relação ao CFO. Suzana argumenta que a formação no CFO "é um pouco precária" e precisa ser atualizada. A participante traz como sugestão, mais planejamento buscando adequar a proposta da formação do oficial à demanda da sociedade atual. Jonas, ao contrário, considera o CFO como sua base mais importante, relata ter tido uma boa formação, construiu pensamento de gestor e a prática é, em sua opinião, um complemento. Gabriel também relata que foi bem formado, que desenvolveu habilidades importantes como saber lidar com as crises, com as pessoas; aprendeu a valorizar o respeito pelo outro e os rituais militares. Ele pondera que as maiores dificuldades são vivenciadas fora da APM, com falta de recursos e instrumentos para resolver os problemas, ficando na base do "se vira!". O que é particularmente interessante aqui, na fala de Gabriel, é a maneira como ele avalia o fato de haver "aprendido" a respeitar as pessoas: o fato de ter sofrido com o desrespeito durante sua formação no CFO foi o que o motivou a agir exatamente da forma contrária em sua prática! Ele diz que: "Por tantas vezes a gente foi desrespeitado, a gente aprende como não fazer. Não vou fazer assim, vou ter respeito com o próximo, vou tratar ele bem, pra chamar a atenção...". Trata-se de uma colocação bastante provocadora e que merece especial discussão. 


\section{5 - ENTREVISTAS INDIVIDUAIS COM COORDENADOR E INSTRUTORA}

O Coordenador do CFO (Capitão Rafael - nome fictício) e a instrutora da disciplina Polícia Comunitária (Capitão Ana - nome fictício) foram entrevistados após as entrevistas com os cadetes.

\subsection{1 - Análise Entrevista Capitão Rafael - Coordenador CFO (nome fictício)}

\section{1 - Significado da carreira de Oficial da PM}

\section{Trecho 1 (linhas 1 a 6)}

"PESQUISADORA: Bom, então nós vamos conversar sobre essas questões de valores humanos, dentro da carreira oficial da Polícia Militar. Gostaria que você iniciasse me contanto porque você escolheu a carreira de oficial da Policia Militar.

RAFAEL: Bem, ao longo de toda a minha vida, eu sempre tive uma certa simpatia pelo militarismo... Eu gostava muito, principalmente da questão das forças armadas, e... Deslumbrava nisso uma posição... Uma possibilidade de mudança de vida também! Especialmente financeira!"

\section{Trecho 2 (linhas 11 a 17)}

"R: Ao longo da minha adolescência eu prestei concurso para as escolas militares... Da... Do exército, principalmente, mas não tive êxito, aí acabei trabalhando como escriturário na caixa econômica federal, mas sempre nutrindo a simpatia pelo militarismo. Aí aos meus 19 anos um amigo meu falou assim: "vamos entrar na Polícia Militar?". Aí nisso a gente veio fazer a prova. Eu fiz a prova dentro da PM mesmo, isso em 95. E passamos! Aí no dia de entregar a documentação eu fui e ele não foi... Aí eu fui mandado pra fazer o Curso de Formação de Soldado, no CFAP."

\section{(...) (linhas 52 a 54)}

"R: E... Fui passando nos concursos, subindo de posto. Passei no concurso de sargento, e depois passei pro concurso de oficial, fiz o CFO. No meio do curso de sargento eu passei pra oficial. Formei em 99, e aqui estou!"

\section{Análise 1}

Nesse primeiro trecho observamos que a escolha pela carreira de oficial da PM ocorreu pela simpatia ao militarismo, com a tentativa de ingresso nas escolas do Exército, e também pela possibilidade de mudança de vida, sendo destacado o aspecto financeiro. Começou a carreira como soldado, em 95, depois passou no concurso pra sargento e, no meio do curso, passou para oficial. Demonstra um bom nível de dedicação à carreira militar, uma vez que se esforçou para passar nos concursos e acelerar sua ascensão. 


\section{Trecho 1 (linhas 75 a 78)}

"P: E o que te motivou a ir pra área de ensino da PM?

R: A área de ensino... Eu sempre gostei do magistério, mesmo na adolescência, eu fazia artes marciais, especialmente a arte chamada Taekwondo e eu via também ali, uma possibilidade de mudança de vida!"

\section{(...) (linhas 83 a 86)}

"R: Agora, na Policia Militar, principalmente após o Curso de Formação de Oficiais, onde eu tive um contato um pouco maior com a questão da didática, falar em publico, e eu vi que não tinha dificuldade... Resolvi então envergar pelo lado do ensino aqui na PM também!"

\section{Trecho 2 (linhas 98 a 110)}

"P: E como coordenador do CFO, como você avalia seu trabalho?

R: Olha, eu entendo que aqui é um local, um ponto estratégico para Policia Militar. Quando eu fiz o meu curso de cadete aqui, eu... Meu comandante da época, eu me espelhava bastante nele, eu olhava para o capitão que estava aqui nessa função e pensava "Nossa, um dia quero ser igual a ele". Mas nunca vislumbrei estar sentado aqui nessa cadeira, estar no comando aqui né? Mas por destino a gente está aqui, estamos aqui e eu encaro também como desafio vir pra cá, meio que é... Como eu digo? Não foi a contra gosto, mas acabei por desaguar aqui. Quando me falaram da possibilidade de comandar o CFO eu também encarei como um desafio, porque eu entendo que a pessoa pra estar aqui, ela tem que ter a vida profissional ilibada, uma vida profissional positiva, não pode ter nada assim, que desabone ele. A vida pessoal (ênfase) também tem que estar ilibada, uma vida é... Calcada ali na questão do exemplo né? Então, eu resolvi encarar esse desafio e aqui estou! É uma dedicação muito grande, chega muito cedo, sai muito tarde... São 76 cadetes, 76 vidas... Pra gente cuidar né? 76 famílias..."

\section{Análise 2}

O primeiro trecho mostra que Rafael descobriu seu "gosto" pela docência quando na adolescência, praticava artes marciais e via uma facilidade em auxiliar os colegas que tinham dificuldade. Depois, na PM, também percebeu essa facilidade e desde que terminou o CFO atua na área de ensino, como instrutor. A função de coordenação surgiu, segundo seu relato, de forma surpreendente, pois ele não almejava essa função. Mas considerou como um desafio, porque considera que o perfil da pessoa que ocupa essa função exige conduta "ilibada". Esse é um termo muito utilizado no militarismo para retratar pessoas com boa índole, honestas, que representam um exemplo a ser seguido. Na fala de Rafael, ele está na função por possuir esse perfil, não fazendo referência a nenhuma outra competência ou habilidade que ele julgue necessária para o cargo. 
3 - Conflito e suas funções

Trecho 1 (linhas 128 a 141)

"P: Agora gostaria de conversar um pouquinho sobre conflito. O que você considera como conflito?

R: Conflito? (pausa média) Eu entendo como... Conflito é um... Uma divergência de interesses né? Eu olho por esse lado... É... Conflito de interesses, conflito de posicõoes né? Uma divergência!

P: Existe pra você algum tipo de conflito que possa ser importante ou positivo, de alguma maneira?

R: Eu entendo que o conflito é uma oportunidade de aprendizado. Quando o conflito é bem resolvido, ou bem mediado, eu entendo que ali há uma possibilidade de crescimento. Até porque a gente pode ver o exemplo dos conflitos mundiais... Primeira e segunda guerra mundial. Avançou-se muito tecnologicamente, avançou-se muito na questão da medicina, e em várias outras técnicas. É claro que é um preço muito caro né? De várias vidas! Segunda guerra mundial teve 59 milhões de pessoas mortas, né? Agora, o conflito sendo bem resolvido e bem mediado, é uma oportunidade de crescimento né? "Mar calmo nunca fez bom marinheiro"."

\section{Análise 3}

O conceito de conflito apresentado por Rafael segue o senso comum, no entanto, considera o conflito como positivo e traz uma frase de efeito para exemplificar seu pensamento a respeito: "Mar calmo nunca fez bom marinheiro". Nessa fala ele considera que o conflito é uma oportunidade de crescimento e que seria ele (o conflito) o responsável pela oportunidade de desenvolvimento.

\section{4 - Violência: Conceito e Valor}

\section{Trecho 1 (linhas 160 a 166)}

"P: O que você entende como violência?

R: Violência? Violência é um fenômeno atrelado à sociedade. A violência é bíblica né? A criminalidade, a violência é bíblica. Nasceu lá com Caim e Abel e na minha opinião... Não acaba! Não tem como acabar! Enquanto tiver sociedade vai ter violência.

P: Qual o seu conceito de violência? Se você tivesse que definir para alguém, como seria?

$\mathrm{R}$ : Violência... Eu entendo que seria um resultado agressivo né? De questões sociais, ou até mesmo da pessoa... É um ato brusco, a agressão... Seria mais ou menos algo assim. "

Trecho 2 (linhas 178 a 186) 
"P: Na sua opinião, o que funciona melhor: a punição, a repressão, ou a prevenção?

R: Olha, eu entendo que é... A prevenção ajuda sobremaneira. Mas também ela sozinha não resolve! Não resolve! E a repressão, ela também é necessária! Então eu entendo que as duas andam lado a lado. Juntas! E vai ser difícil desatrelar uma da outra. Nossa sociedade atualmente, eu digo, tanto a mundial como a brasileira... A sociedade do Estado $X$ não consegue desatrelar. Não estamos preparados pra isso né? Então tem que ter a prevenção, mas a punição também, a repressão também é... É necessária! Eu até tenho uma máxima comigo: "A certeza da punição é o que resolve o problema!" Então se a pessoa tiver certeza que ela será punida, diminui sobremaneira o comportamento dela. "

\section{Trecho 3 (linhas 195 a 204)}

"R: Em 2001 eu acabei por ir trabalhar em uma unidade especializada aqui da capital. Fiz o curso e fui trabalhar lá. Trabalhei lá por cerca de 1 ano e pouco. E lá eu trabalhava, eu costumo fazer um trabalho assim, lá eu trabalhava com um produto da sociedade, aquele produto que deu problema, aquele produto defeituoso, que é o criminoso. E geralmente era um criminoso que não tinha mais recuperação, tem a maldade no sangue! Então é aquele criminoso que você tem que prender e entregar pra justiça. E aquilo ali não me... Não me... Não me satisfazia! Aquele negócio de ficar correndo atrás da bandidagem, prender bandido... Porque eu entendo que a bandidagem não acaba! Aí eu mudei radicalmente de área. Sai do serviço, onde eu corria atrás do ladrão, e fui pro Colégio Militar."

\section{(...) (linhas 208 a 213)}

"Alí eu vislumbrei a possibilidade de trabalhar com o produto da sociedade que é a criança, o jovem, que lá a gente tem... Tinham garotos na faixa de 10,12 anos, que estavam no ensino fundamental, até o adolescente do Ensino Médio. Então eu saí do produto final, que deu defeito, pra ir pra linha de montagem, na esteira né? E fiquei satisfeito, porque, após trabalhar lá 3 anos, encontrei alguns desses garotos, hoje já adultos, me reconhecem e me dizem que aproveitaram alguns ensinamentos, aproveitaram algumas dicas, algumas falas $\underline{\text { né?" }}$

\section{Análise 4}

A questão da violência é compreendida e expressa por Rafael como algo inerente à natureza humana e que não vai acabar. "A criminalidade, a violência é bíblica. Nasceu lá com Caim e Abel e na minha opinião... Não acaba! Não tem como acabar! Enquanto tiver sociedade vai ter violência". Também a define a partir do conceito de agressão; seriam atos que envolvem agressão. Ele considera que prevenção e repressão andam juntas, que são duas ações necessárias, mas novamente traz uma frase de efeito onde expressa que a punição teria um peso maior, pois "A certeza da punição é o que resolve o problema!". No trecho seguinte 
vemos uma contradição relativa à essa análise anterior, pois ele defende a repressão, mas ao mesmo tempo cita um exemplo vivenciado onde o trabalho repressivo não o estava satisfazendo, e ele buscou um local onde poderia trabalhar de forma preventiva. Chama atenção os termos utilizados "produto da sociedade que deu problema, aquele produto defeituoso", referindo-se ao infrator da lei; e "o produto da sociedade que é a criança, o jovem", referindo-se ao público alvo do Colégio Militar onde ele foi trabalhar. São termos minimamente pejorativos, que excluem completamente a subjetividade e a construção do sujeito ativo, o qual teria consciência e poder de decisão sobre si mesmo.

\section{5-Paz: Conceito e Valor}

\section{Trecho 1 (linhas 282 a 293)}

"P: Hoje em dia fala-se muito da construção da paz. Como você define paz? R: $\underline{\text { Paz é a }}$ tranquilidade social! Eu entendo que a partir do momento que uma pessoa é cumpridora de seus deveres e obrigacõos, isso daí já tá contribuindo sobremaneira pra tranquilidade social... Pra paz!

$\mathrm{P}:$ Você acha que é possível construir a paz no mundo atual?

R: (pequena pausa) "Só vive em paz quem aprende a lutar!" Então assim, é... Eu nunca vi uma paz que não tenha sido conseguida em razão de uma luta, até mesmo de uma guerra anterior, então... Nós vivemos uma guerra todos os dias né? A sociedade ela é complicada, vários vieses, então assim... É pregado aqui pra eles (cadetes), a busca da paz, a busca pela tranquilidade social né? Mas eu acho que ela tá ás vezes um pouco distante né? Não está muito alcançável... Ás vezes está no plano das ideias..."

\section{Análise 5}

Define paz como "tranquilidade social" e pondera que as pessoas viverão em paz se cumprirem seus deveres e obrigações conforme as leis sociais. Porém não cita os direitos do cidadão, nem o compromisso do Estado, do governo, em garantir estes direitos como forma importante de construir a paz...Um conceito, de certa forma, reducionista, que desconsidera responsabilidades coletivas, compreensões sobre os direitos do outro e tolerância pelas diferenças. Exatamente por essa visão, ele considera que construir a paz no mundo atual seja algo "do plano das ideias". Apesar de ser um conceito trabalhado junto ao CFO, ele assume não acreditar nele. Faz uso de outra frase de efeito para tentar elucidar seu pensamento: "Só vive em paz quem aprende a lutar!". Mas ele não elabora sobre como seria esta luta! Lutar contra quem? Contra o que? E como? É interessante ele considerar a luta como meio de se alcançar a paz, mas seguindo sua análise será uma luta em vão, porque a paz é algo inalcançável, do plano das ideias. Parece, aqui, considerar ser importante o 
sujeito ser conformado e apenas cumprir com seus deveres, e não lutar por seus direitos. Sendo ele o comandante, era de se esperar que ele elaborasse um pouco melhor a grande complexidade da questão e os grandes dilemas enfrentados pela policia.

\section{6 - Formação do Oficial na PM}

Trecho 1 (linhas 220 a 225)

"P: E no CFO, você acha que essa relação entre prevenção e repressão da violência, ela é bem discutida?

R: Olha, eu entendo que... É... Dentro da grade curricular deles, sim, eu entendo que sim! E também eu vislumbro com um olhar positivo que a SENASP, Secretária Nacional de Segurança Publica, ela tem um curso né? De prevenção de violência... Prevenção e Combate da Violência né? E eu sei que a maioria dos cadetes também fizeram esse curso né? Então eu acho que sim!"

\section{(...) (linhas 234 a 236)}

"P: Você acha que é suficiente? Satisfatório?

R: Eu entendo que inicialmente, ele é suficiente, é claro que não se esgota em si. Aí depois cada um vai procurando se especializar, vai procurando um pouco mais de conhecimento na área né?"

\section{Trecho 2 (linhas 274 a 278)}

"P: E dentro do CFO hoje, você consegue identificar algum aspecto que favorece a utilização de algum tipo de violência?

R: Não! Eu entendo que não... Porque dentro da instituição né? No currículo programático deles, é ensinado a questão da tolerância, é ensinado a questão da mediação, de conflitos... É ensinado ao policial hoje (ênfase) que ele na verdade é um mediador de conflito né? Então isso é importante!"

\section{Trecho 3 (linhas 294 a 301)}

"P: Você acha que o CFO promove a construção da Cultura de Paz?

R: Promove! Promove sim! Porque eu entendo também que, houve uma mudança no conteúdo programático na grade curricular no curso de formação! A minha formação inicial foi como soldado há 20 anos atrás, foi uma formação voltada pra o militarismo. E a formação agora, especialmente com a chegada da SENASP, Secretaria Nacional de Segurança Publica, que propôs um currículo programático, uma grade curricular diferenciada, voltada para o cidadão (ênfase), deixando um pouco de lado o militarismo, e voltada mais pra questão policial. Eu entendo que foi sim uma... Mudança incrível!"

Trecho 4 (linhas 314 a 320)

"P: Tem alguma atividade ou disciplina que você vislumbra essa discussão de uma forma 
mais direcionada, focal?

R: Olha, eu entendo que, por exemplo, a introdução do Policiamento Comunitário, da disciplina de Policiamento Comunitário, no primeiro momento, foi a abertura desse novo pensamento né? Então, todos os cursos, dentro da Policia Militar, tem essa matéria e também Direitos Humanos! Isso aí já é assim, um marco inicial! E eu entendo, especialmente na formação dos cadetes, que... É fundamental!"

\section{Análise 6}

Nesse trecho Rafael fala sobre a formação do oficial. Considera como suficiente o que é ministrado no CFO a respeito de prevenção e repressão da violência. Argumenta que os cursos da PM "hoje" são voltados para uma formação baseada na tolerância e na mediação de conflitos, considerando que essa mudança veio com a inserção da Matriz Curricular proposta pela Senasp em 2005. Ele pondera que sua formação inicial na PM há 20 anos, era voltada apenas para as questões militares e que depois dessa "Mudança incrível!", a formação é voltada para a cidadania, considerando as demandas sociais. De uma forma geral, ele diz estar satisfeito com a formação oferecida aos cadetes, acha que as discussões contemplam a temática da pesquisa, mas também considera que o conhecimento não se esgota no curso.

\section{7 - Prática policial}

\section{Trecho 1 (linhas 255 a 269)}

"P: E as práticas da Policia Militar, de uma forma geral, você diria que elas envolvem violência?

R: Olha, não é ensinada violência em momento algum nos cursos da PM né? No meio acadêmico, no meio da Policia Militar não é ensinado em momento algum a violência! É ensinado que, inclusive, legalmente e sendo necessário, pode-se fazer o uso da violência para garantir a ordem e a tranquilidade. $E$ é um direito assegurado na nossa Constituição. $\underline{0}$ direito de outra pessoa vai até onde começa o meu! Inclusive a Policia Militar acaba sendo esse braço armado... Esse braço forte do Estado né? Quando é necessário usar da força!

$\mathrm{P}$ : Você acha que em algum caso a ação violenta da PM é necessária?

R: É... Eu não vejo em caso algum! Ela acaba sendo compelida a agir com o uso progressivo da força e não da violência! Então a violência em si, a violência gratuita ela não... Não é necessária, não é recomendada e não é orientada nos quadros da Policia! Na atividade policial, vez por outra, a policia é compelida a agir com força física, mas dentro dos parâmetros legais né? É o que é ensinado! Agora, o que acontece é que pode acontecer de um ou outro policial, agindo de maneira isolada, ás vezes querer ultrapassar os limites da 
legalidade. Seja por inexperiência, por afoito demais... Alguma coisa nesse sentido!"

\section{Análise 7}

Sobre as práticas da Polícia Militar, Rafael afirma que não é ensinado sobre o uso da violência nos cursos da PM e que as discussões consideram o, uso progressivo da força, legalmente garantido para que a instituição possa manter a ordem e tranquilidade social, uma de suas principais funções. Considera também, que a PM é "o braço armado do Estado", e é interessante que, para ele, o uso da fora e a violência são duas coisas diferentes. Ele não elabora muito sobre esta complicada questão, e parece, com sua narrativa, querer defender a PM com frases do tipo "Olha, não é ensinada violência em momento algum nos cursos da PM né", ou então "É... Eu não vejo em caso algum! Ela acaba sendo compelida a agir com o uso progressivo da força e não da violência!". Ele reitera e frisa que a violência "Não é necessária, não é recomendada e não é orientada nos quadros da Policia!". Porém, admite que existem práticas violentas individuais por alguns policiais, o que considera como ação isolada, atribuindo a estes policiais "falta de experiência" ou a qualidade de ser "afoito". O uso deste adjetivo não deixa muito claro o que ele quer dizer, mas o certo é que não usa em nenhum momento adjetivos como "violento" ou "impulsivo", "destemperado", dando a entender que este tipo de policial não existe na corporação, sendo todos os policiais experientes equilibrados e justos na aplicação da força. Nesse trecho, o coordenador do CFO defende veementemente a ação dos policiais militares em geral, e em especial, defende que a formação dos cadetes não preconiza nem reforça o uso da violência em suas práticas.

\section{8 - Sugestões e ideias para a PM promover a Cultura de Paz}

\section{Trecho 1 (linhas 337 a 348)}

"P: Você acha que a Polícia Militar promove a construção da Cultura de Paz?

R: Eu entendo que sim! Ela colabora (ênfase)! Colabora sobremaneira! E procura se adaptar ao que a sociedade precisa né?

P: Tem alguma prática ou algum programa da Polícia Militar, que você considera importante para essa mudança de cultura que você citou?

R: Sim! Por exemplo, é... A Policia Militar, ela tem é... A questão do Policiamento Comunitário, que é um policiamento de proximidade com o cidadão. Então eu vejo isso com bons olhos, e tem surtido bons resultados. O... O PROERD, que é um programa de resistência às drogas, que causa uma simpatia muito grande da sociedade para com a policia e produz bons frutos né? Os Colégios Militares também, que eu entendo que é uma... Apesar de não ser a nossa missão principal, mas é um viés que está dando bons 
resultados!"

Trecho 2 (linhas 351 a 362)

"P: Qual ideia ou sugestão você teria, de como a PM poderia contribuir para construção de uma Cultura de Paz?

R: Olha, eu entendo que... O que a policia tem que aprender, a policia que falo assim, os policiais em si... é difícil mudar uma cultura! Você chegar aqui e mudar uma cultura é complicado! Então eu até tenho comigo que é difícil mudar a cultura, o que você tem que aprender é implementar uma cultura de mudança né? Implementar uma cultura de mudança? O que é isso? Se eu chegar aqui e tentar mudar a sociedade de uma vez, ou aquela cultura de uma vez, eu não vou conseguir! Agora se eu implantar uma cultura de mudanç, todos os dias eu mudo um pouco, eu vou me adaptando a realidade, o que é colocado ali... É mais ou menos igual aquela teoria de Darwin né? $\underline{\mathrm{Da} \text { evolução das }}$ espécies. $\underline{O}$ que foi evoluindo, não foi o mais forte, e sim aquele que conseguiu se adaptar melhor ao ambiente. Então, aqui é a mesma coisa. A Policia Militar, ela tem (ênfase) que se adaptar ao que a sociedade precisa!"

\section{Trecho 3 (linhas 376 a 390)}

"P: Pra finalizar, você tem alguma sugestão ou ideia pra promover a Cultura de Paz na sociedade?

R: (pausa média) Assim, eu diria que... A primeira... A primeira providência é conscientizar o policial militar, de que essa subcultura policial... Essa cultura de que o policial, ele é superior ao tempo, superior às dificuldades, e... Que ele é o super homem, que ele vai mudar o mundo, que ele sabe tudo... Então ele tem que se conscientizar que ele também é uma pessoa que veio do povo e ele representa o povo! Ele não veio de Marte... Ele saiu da sociedade, está emprestado aqui pra fileiras da corporação, vai prestar o seu serviço... $\underline{\mathbf{A}}$ policia vai usa-lo, e depois quando ele for pra reserva, se aposentar, ele vai voltar pra mesma sociedade!

P: Esse seria o primeiro passo, a primeira providência, na sua opinião?

R: A primeira providência! Tomar consciência de que antes dele ser um policial, antes ele é um cidadão! E que tem seus deveres, obrigações, direitos...

$\mathrm{P}:$ E depois?

$R: \underline{O}$ segundo passo acho que seria colocar em prática os ensinamentos que são ministrados aqui né? Que é a observância da legalidade, de trabalhar dentro dos preceitos e parâmetros legais, isso aí já... Já é de grande valia!"

\section{Análise 8}

Nesse trecho final, Rafael considera que a Polícia Militar colabora sobremaneira para a 
promoção de uma Cultura de Paz, através de seu trabalho. Cita o Policiamento Comunitário, - Proerd e os Colégios Militares, como programas que considera de sucesso para a promoção da Cultura de Paz. Por outro lado, também reflete que implementar uma cultura de mudança é algo difícil, mas necessário para a evolução da própria PM. Como sugestão para que a PM possa contribuir para a construção de uma Cultura de Paz na sociedade, ele acha que a primeira providência a ser tomada é conscientizar o policial militar de que ele também é um cidadão, que "Ele saiu da sociedade, está emprestado aqui pra fileiras da corporação (...) e vai voltar pra mesma sociedade". Ou seja, Rafael defende que há um risco do policial construir uma autoimagem de super-homem, que resolve tudo e considera que isso afasta o policial de sua cidadania. No entanto, em sua própria fala, ele deixa a entender que a profissão de policial militar retira a pessoa da sociedade em que vive! Ele diz "A polícia vai usá-lo, e depois quando ele for pra reserva, se aposentar, ele vai voltar pra mesma sociedade!". Fica, assim, a pergunta, como ele vai se ver "antes como um cidadão" e "tomar consciência de que antes dele ser um policial, antes ele é um cidadão!" que tem "deveres, obrigações, direitos", se ele mesmo afirma que "quando (o policial) for pra reserva, se aposentar, ele vai voltar pra mesma sociedade!"? Sua fala sugere que o policial não está inserido na sociedade, já que ele deverá "voltar" para ela. Em segundo lugar, ele apresenta como sugestão algo que já deveria acontecer naturalmente, que seria o policial "colocar em prática os ensinamentos que são ministrados aqui (APM)". Se ele considera que a formação é suficiente, coerente e baseada na legalidade, porque será que esse aprendizado não é aplicado naturalmente após a formatura? Como ele já trabalhou em outras unidades da PM e tem 20 anos de experiência, talvez observe comportamentos e ações incompatíveis com a formação que ele apresentou aqui como adequada. As razões para essa incompatibilidade deveriam ser melhor discutidas por pessoas em funções estratégicas como a que ele ocupa hoje como coordenador do CFO. 


\subsection{2 - Análise Entrevista Capitão Ana - Instrutora CFO (nome fictício)}

1 - Área de ensino da PM

Trecho 1 (linhas 3 a 13)

"PESQUISADORA: Bom, então a primeira coisa que eu gostaria de saber é... o que te motivou a trabalhar na área de ensino? Ser instrutora da Polícia Militar?

ANA: A instrução, ela... eu sempre tive a compreensão que ela faz parte do nosso engrandecimento, tanto profissional como do ser humano mesmo. Então, isso sempre me chamou a atenção. E... eu acho que dividir o conhecimento ele é importante principalmente na Polícia Militar, porque nós lidamos com a transformação das pessoas. Então a... matéria específica é... independentemente do que a gente vai tratar, eu entendo muito que dar aula, passa por esse pressuposto de você poder acrescentar algo em alguém. E que ela venha construir algo que possa ser útil tanto na vida profissional como na pessoal também. Então, o que me chamou muita atenção, me despertou isso inicialmente foi... eu acho que a chance da gente poder contribuir um pouquinho na, na evolução daquelas pessoas ali."

\section{Análise 1}

Nesse trecho inicial, Ana fala sobre seu interesse pela área de ensino na PM. A concepção que ela tem de ensino é de contribuição, construção de conhecimento. Vale ressaltar que ela acredita que pode contribuir com a "transformação" ou "evolução" das pessoas, o que é um posicionamento bem diferente do participante cadete Davi, que acredita que a formação "vem de berço".

\section{2 - Polícia Comunitária}

\section{Trecho 1 (linhas 17 a 26)}

"P: E como surgiu o interesse por essa temática... de você ministrar aula sobre Polícia Comunitária?

A: Eu apreendi que... a operacionalidade era vista de uma forma muito reativa e lá nesse Batalhão onde eu fui trabalhar, eu tive a compreensão de que se a gente quisesse melhorar e prevenir as questões que envolvem a criminalidade de uma forma geral eu teria que buscar métodos preventivos... E não tem como você trabalhar com prevenção se você não falar em parceria! Então ali no Batalhão onde eu fui trabalhar depois de formada, eu estabeleci dentre daqueles conceitos que eu entendia né? Que eram corretos, que a filosofia de Polícia Comunitária ela lida muito com isso, ou seja, a gente ééé realizava parceria dentro de uma comunidade com fim de resolver problemas, proporcionando qualidade de vida para aquelas pessoas, porque Polícia na verdade ela trabalha sempre em conjunto, nunca de forma isolada." 


\begin{abstract}
Trecho 2 (linhas 257 a 271)
"A: E a gente fala que a gente trabalha com Polícia Comunitária, com 6 grandes grupos. Então você tem que trabalhar com: 1- a comunidade; 2 - você tem que trabalhar com a polícia, organização policial, de uma forma efetiva, pra justamente quebrar tudo isso que nós estamos falando; 3- você tem que trabalhar com os poderes constituídos principalmente Judiciário, Ministério Público, de uma forma muito próxima. Você tem que estar próximo deles para que você consiga ter essa razão de, de existir ali também e eles te darem a fundamentação pra isso, né? Senão você perde também o seu foco; 4- você tem que trabalhar com os conselhos de segurança, que é outra forma também importantíssima, porque lida e busca 0,0 , a questão do, do, dos problemas detectados lá; 5 - você tem que trabalhar com os comerciantes que é outro fator também preponderante, né? Pra que a gente consiga também ter resultado, porque é aonde circula o dinheiro, tudo isso, então que medidas ele está tomando pra, pra, pra essa, pra que esses fatores deem certo, né? $\underline{6-E}$ outro ponto também importantíssimo, que eu considero que é o mais... a mídia... A imprensa. Então quando você consegue trabalhar com a imprensa e mostrar que a polícia, ela, ela acerta muito mais do que erra, né? Você consegue também transmitir segurança para a comunidade."
\end{abstract}

\title{
Análise 2
}

Nesse trecho Ana explica sua escolha pela área de Polícia Comunitária, suscitada a partir de seu primeiro trabalho após a formatura no CFO. Segundo seu relato, a prática revelou a necessidade de desenvolver ações preventivas e integradas, pois as reativas eram insuficientes para o combate da criminalidade em sua região de trabalho. No trecho 2, ela explica quais as parcerias necessárias para se desenvolver o Policiamento Comunitário, demonstrando muita familiaridade e credibilidade no trabalho.

\section{3 - Desafios como instrutora na PM}

\section{Trecho 1 (linhas 138 a 145)}

"P: Aproveitando o gancho dessa temática da instrução, gostaria de saber quais são as maiores dificuldades que você encontra como instrutora?

A: A maior dificuldade que nós encontramos como instrutores, eu acho, do meu ponto de vista, é quando você é... vai dar aula para uma pessoa que ela já conhece a Policia Militar. Então vou te dar um exemplo, um cara, que era, por exemplo, soldado da Polícia Militar, sargento, cabo, e ele passa no CFO, né? A gente tem uma dificuldade para lidar com esse policial, por quê? Por que esse policial já vem com toda uma carga de pré-conceito com relação a atividade. Então esse é um desafio. Então você tenta mudar concepções. Mudar 
concepções é algo dificílimo, né?"

\section{(...) (linhas 149 a 153)}

"A: E a outra grande dificuldade que a gente tem é quando você fala tudo isso na teoria e alguém levanta e fala: "tudo bem, na teoria... a gente tá tendo o conceito do que é certo, do que é correto, mas e na prática? Isso funciona?" Ai eu digo: "Oh, se nos fizermos... aquela velha história da formiguinha né? Se cada um fizer a sua parte, com certeza a gente vai conseguir ter um mundo melhor". Agora, é fácil? Não! Os desafios são imensos? Imensos!"

\section{Análise 3}

É interessante observar nesse trecho, que a participante não cita nenhuma dificuldade de ordem estrutural ou institucional, mas relacionada à reconstrução de conceitos, considerando que os alunos já trazem conceitos formados a respeito da temática abordada. Talvez essa dificuldade apresentada pela instrutora possa ser caracterizada como um desafio, no entanto, o fato dela ter citado isto como sua "maior dificuldade" nos faz pensar que reconstruir conceitos e concepções pode ser, pelo fato de estarem associados a crenças e valores afetivamente arraigados, a grande dificuldade dos instrutores.

\section{4 - Formação do Oficial na PM}

\section{Trecho 1 (linhas 394 a 401)}

"P: Você acha que o Curso de Formação de Oficiais ele promove uma Cultura de Paz?

A: Eu acho que entre os cadetes... porque... entre os cadetes, o quê que vai acontecer? Eles... Na verdade na dificuldade, a gente, o que? Une, né? Então entre eles, eu acho que promove. Mas formaria, uma "ques"... uma "questão"...pra, pra quem tem uma visão crítica, né? Que consegue compreender isso, consegue perceber que o que estão fazendo ali... lógico, que muitas práticas são acertadas, mas muitas práticas são erradas. Então eu acho que eles (os cadetes) ééé, conseguem ter essa compreensão de que, de que isso é certo e isso é errado ali, mas não gera um dissabor entre eles, entendeu? Eles se unem! Com a dificuldade, se unem."

\section{Trecho 2 (linhas 426 a 442)}

"P: E a prevenção? Você acha que o CFO promove essa discussão do é prevenção e promoção da violência?

A: Não, eu acho que o curso, se a gente for, ééé, na filosofia da, da teoria que tinha que falar, eu acho que ele promove muito mais a questão da prevenção, do que a prática da violência. Aí eu, eu tenho a compreensão que a gente foca muito mais na prevenção, em todas as disciplinas. Até quando você pega o POP, onde a PM baseia todas as suas ações, ele é muito técnico, muito profissional, e visa justamente isso, a prevenção. 
P: A sua disciplina, você considera que ela contempla isso, as discussões a respeito da violência e prevenção?

A: Contempla... Contempla isso também, logicamente.

P: Que materiais você utiliza pra falar de violência com os seus alunos?

A: Geralmente pra falar de, de, de violência com meus alunos, eu uso muito a questão, ééé, logicamente porque, porque, eu tenho auxílio do próprio projetor que, que traz algumas questões temáticas, ou seja, eu passo um filme pra eles, eu passo uma questão de vídeos, né? Eu passo, por exemplo, entrevistas, que eu tive a percepção: "olha a postura e a conduta daquele oficial! Ao falar desse ou daquele assunto. Olha a conduta daquele policial, quando ele externou o sentimento dele pelo agressor social..."."

\section{Trecho 3 (linhas 626 a 647)}

"P: Você acha que a Matriz Curricular do CFO contempla essa formação de um oficial que promove a Cultura de Paz, que é mediador de conflito, ou ela ainda precisa ser melhorada nesse sentido?

A: Não, não... dessa agora, eu num, eu num poderia nem falar, porque eu não tenho muito conhecimento da Matriz Curricular... Mas assim, na minha época, por exemplo, tinham matérias que poderiam ser... Eu acho assim, menos enaltecidas, né?

P: Por exemplo?

A: Ordem unida (pequena pausa). É uma prática que muitas das vezes você perde muito tempo com aquilo, enquanto você poderia estar dedicando a outros pontos. Então ééé. Estatística, por exemplo, né? Éééé você pode trabalhar uma questão de análise criminal, que é muito mais viável. Então assim, e aí é onde eu falo que eu acho que a docência, ela é uma questão de, de, de, na verdade a pessoa tem que ter, ser vocacionada, e muitas das vezes as pessoas que estão ali, não tem talento nenhum pra ser docente, né? Então, isso também é um grande problema, da, da, da nossa, da nossa, ééé, do nosso curso de formação.

P: Você acha que deveria ter uma seleção mais criteriosa?

A: Acho que sim. Não, na verdade tinha que existir seleção! Acho que assim, a pessoa tinha que ir lá pra frente, dar... "Amigo, qual que é a sua matéria? Quais são as suas disciplinas?" "Essa, essa e essa". "Beleza". Ter uma banca com quatro lá. "Por favor, quais são os recursos que você utiliza para dar aula? Explica para nós... fala da sua formação, fala um pouquinho da matéria... Como você pretende mudar as concepcões dessas pessoas aqui?" Tinha que ser por aí... Eu acho que deveria ter seleção pra entrar e uma seleção muito rígida, né? Muito bem feita por pessoas ali capazes também de avaliar aquele, aquele docente, eu acho."

\section{Trecho 4 (linhas 658 a 668)}

"P: De uma forma geral essas práticas extracurriculares, como algumas palestras, as 
solenidades, os rituais da PM... Você acha que eles contribuem para a formação do oficial?

A: (Pausa pequena) Eles ajudam se você se comportar da maneira que deve ser, ou seja, tem uma solenidade que nós vamos receber o governador de Estado, por exemplo, ali no pátio. Então o governador de Estado vai chegar ás 10h da manhã. Coloca a tropa às $7 \mathrm{~h}$ da manhã em forma (pausa pequena) o porquê disso? (pausa média) Então elas passam a ser altamente renegadas por quem está lá. Então essas questões são plurais também, passam por tudo isso, né? É que fazem com que essas questões culturais, os rituais dentro da Polícia, as tradições... tornam-se um pouco é... desgastante, negativo, cansativo, essas coisas... Por que elas não vem a atender aquilo que as vezes era previsto né? Por exemplo, uma pessoa vai ali para discursar, a tropa no sol durante 3,4 ou 5 horas, né? Então isso é muito desgastante.

\section{(...) (linhas 672 a 675)}

A: Se você fala pra mim: "Você gosta?" Não! Não tem como um ser humano... Eu acho que ninguém gostaria de um negócio desses... (pausa pequena) não tem como gostar. Agora se fosse uma prática mais objetiva "olha só, tem que receber uma pessoa..." Meia hora antes em forma, recebe, desfila e tal. Louvável! Excelente! Excepcional!"

\section{Análise 4}

Esse item discute vários assuntos dentro da abrangência da formação do CFO. No trecho 1, Ana diz que "Eu acho que entre os cadetes... porque... entre os cadetes, o quê que vai acontecer? Eles... Na verdade na dificuldade, a gente, o que? Une, né? Então entre eles, eu acho que promove. Mas formaria, uma "ques"... uma "questão"...pra, pra quem tem uma visão crítica, né? Que consegue compreender isso, consegue perceber que o que estão fazendo ali... lógico, que muitas práticas são acertadas, mas muitas práticas são erradas. Nesta fala, nota-se uma certa dúvida da participante em simplesmente afirmar que sim, o CFO promove uma Cultura de Paz. Acaba por afirmar que sim, promove, mas reduz esta cultura à união dos cadetes. Talvez esteja aqui considerando a união, por um lado, versus a competição, pelo outro...Mas ela não cita a competição. Diz que o CFO promove a Cultura de Paz, porque os cadetes “Eles se unem! Com a dificuldade, se unem!". Mas faz um recorte no conceito de Cultura de Paz, reduzindo-a à união entre os membros de um determinado grupo. No trecho 2, ela considera que o CFO discute a prevenção da violência de forma satisfatória e promove essa prática. Considera que sua disciplina proporciona essa discussão, sendo satisfatória a abordagem da temática no curso. No trecho 3, ela relata não ter conhecimento da Matriz Curricular atual do CFO, já que ela está sempre sendo revisada. No entanto ela levanta dois pontos a serem analisados. O primeiro está relacionado à distribuição da carga horária de algumas disciplinas, que considera como excessivas e 
sugere outras que considera de maior relevância. O segundo, em relação à seleção dos docentes. Em sua opinião, a docência é considerada como uma vocação e não há uma seleção no modelo atual da APM; os profissionais tornam-se instrutores conforme a conveniência de cada um e a APM não tem nenhum critério de inclusão / exclusão no quadro docente. A instrutora propõe uma forma de seleção mais rígida, envolvendo várias fases e avaliação por uma banca qualificada para tal. Essa é uma questão amplamente discutida no âmbito das instituições de ensino militares que, apesar de terem pessoas que concordem com esse pensamento, o processo de seleção docente segue sem parâmetros coerentes. Ana reflete, ainda, sobre os rituais e solenidades militares que considera desgastante da forma como são conduzidos, e considera que estas práticas acabam por se tornar desgastantes e negativas para os alunos. Relata não gostar das solenidades atualmente e acha que os alunos não gostam. Sugere uma prática objetiva, com menos tempo de preparação. Suas ideias geram a questão: afinal, por que dar tanta ênfase nestas práticas cansativas? Que objetivos se pensa atingir com este desgaste todo? Por que não aproveitar melhor o tempo com atividades mais educadoras?

\section{5 - Conflito e suas funções}

\section{Trecho 1 (linhas 316 a 322)}

"P: Pra você o que seria um conflito?

A: Ééé... na verdade, um, um, um conflito é, é, se eu for olhar na área, principalmente né? da Segurança Pública é quando a gente começa a entender que tem interesses ali que são contraditórios, são diferentes, né? Eeeeee muitas das vezes, oooo que a gente percebe na comunidade que esses conflitos eles são, ééé, desde um grau bem pequeno, até um grau muito elevado, né? Uma simples lixeira, tá num lado mais daqui ou dali, entre os vizinhos pode gerar um conflito. Aí pode ir até uma morte ou uma coisa nesse sentido, né?"

\section{Trecho 2 (linhas 332 a 343)}

"P: Você acha que todo conflito envolve violência?

A: (pausa média) Acho que não...

$P$ : Você acha que um conflito pode ser importante ou positivo de alguma maneira?

A: (pausa média). Acho que tem conflito que pode ser positivo sim.

P: Por exemplo...

A: Vamos dar um exemplo... Eu acho que um conflito existente entre um marido e uma mulher, né? Na criação de um filho... Às vezes num conflito que existe ali, com relação à criação daquela criança, pode gerar um fator positivo, ou seja, repensar alguma medida, de buscar... eu acho, que uma razão melhor pra tentar é... postular isso frente à educação 
daquela criança, né? Então, eu tenho a compreensão que alguns conflitos, eles venham para esclarecimento até pessoal e profissional também, né? Então eu falo que algumas formas de conflito servem de forma positiva, não de forma negativa."

\section{Análise 5}

Ana hesita um pouco para definir conflito, e acaba descrevendo-o como "interesses contraditórios", considera a existência de diferentes graus para os conflitos, de leve a grave. Ela parece crer que o conflito, não necessariamente, envolve violência e que pode ser positivo ou importante. São considerações interessantes, tendo em vista que ela faz uma análise um pouco mais elaborada que o senso comum a respeito do conflito, compreendendo que o conflito pode ser positivo por ser a base de uma negociação.

\section{6 - Violência: Conceito e Valor}

\section{Trecho 1 (linhas 346 a 350)}

"P: O que você considera como violência?

A: (pausa pequena) É, e aí violência, ela passar eu acho por, por, por várias situacões, né? Éééé se a genteeee... na Polícia Militar é interessante, eu tenho conversado isso com outros colegas, né? Então se você olha pro seguinte aspecto: às vezes a relação, do superior com o subordinado... O simples fato da maneira que ele trata aquela pessoa, pode ser uma forma de violência, né?"

\section{Trecho 2 (linhas 354 a 360)}

"A: A gente pode perceber também ééééé violência de uma forma geral, ou seja, a própria pessoa que é assaltada, né? Recebe uma violência, a pessoa que é roubada, recebe uma violência... $E$ às vezes até, até ela sem perceber, ela pode sofrer essa violência também através de uma, através de uma tipificação normal, que é o furto, né? Quer dizer, entra na sua casa, houve uma situação sob o seu patrimônio né? Ali ela se sentiu violentada, dentro desse aspecto no seu patrimônio. Então, eu acho que a violência, ela é muito ampla nesse sentido."

\section{(...) (linhas 368 a 370)}

"P: Na sua opinião a violência pode ser positiva?

A: Eu acho que a violência é sempre negativa! Na violência eu não vejo nenhum aspecto que seja positivo, diferente do, do conflito..."

\section{Trecho 3 (linhas 495 a 505)}

"P: De uma maneira geral, você acha que, em algum momento, é necessário utilizar violência? Em algum momento a pessoa precisaria utilizar violência?

A: Sentido, eu não vejo nenhum. Usar violência como forma de justificar alguma coisa eu não 
vejo. Só que a gente sabe que o ser humano, muitas das vezes, de uma forma até involuntária, não sei, a gente utiliza uma violência, né? Agora,eu, eu, eu... a gente sempre tem que partir do pressuposto que vivendo em comunidade a violência éééé, ela, ela, ela é aceitável em alguns casos, que a própria legislação nos postula isso, né?

P: Por exemplo...

A: Um exemplo: você vai ser assaltada, eu como policial, né? Então uma reação minha, eu estou fazendo o que? Eu estou praticando uma... uma forma de violência, mas eu estou praticando uma violência justificada pela ação de um agressor."

\section{Análise 6}

Nesse trecho Ana fala sobre sua concepção de violência. Parece não haver refletido muito sobre a definição do termo. Ela reflete que a violência pode ser expressa de várias formas, fazendo referência aos tratamentos entre superiores e subordinados dentro da PM. Ela considera alguns deles como violência. Também exemplifica violência a partir de crimes cometidos contra o patrimônio individual, como roubos e furtos. Interessante ressaltar que ela é categórica ao afirmar "Eu acho que a violência é sempre negativa!". Essa fala reitera que a participante tem concepções distintas para conflito e violência, pois considera que o conflito pode ser positivo, mas a violência não. Por isso ela pondera que não existe nenhum sentido em utilizar a violência, não acha que ela é necessária. No entanto, argumenta que em algumas situações ela é justificada pela legítima defesa ("a própria legislação nos postula isso, né?").

\section{7 -Paz: Conceito e Valor}

\section{Trecho 1 (linhas 526 a 533)}

"P: Ok. A gente também escuta muito falar sobre paz. O quê que você entende como paz?

A: É, aí a paz ela passa, né? Pelo pressuposto que vem dessa tranquilidade social, né? Então quando você fala o seguinte: que, determinada sociedade, por exemplo você pega países muito desenvolvidos. Éééé, dentro de uma, de uma região urbana, você consegue ter uma paz social. O que seria isso? Ou seja, você tem ausência de violência, você tem pessoas que foram educadas pra viver em comunidade, né? Ou seja, aquela pessoa no trânsito ela vai se comportar de uma maneira, né? Na sua vida pessoal ela vai comportar de uma maneira, na sua casa ela vai se comportar de uma maneira, no seu trabalho ela vai se comportar de uma maneira, então quando você se tem esse fato... vários fatores, ou seja, quando você consegue agregar, ou seja, educação na formação daquela pessoa, você consegue que o Estado proporcione todas as razões para que aquela pessoa venha a ter seus direitos resguardados, você consegue propiciar isso." 


\section{Trecho 2 (linhas 543 a 556)}

"P: Entendo. Você acha que é possível construir uma Cultura de Paz no mundo hoje?

A: (pausa pequena) É aí tem uma questão de religião, uma questão muito mais ampla, né? Ai tem, eu acho que no mundo, você fala assim... Eu acho que nós estamos longe disso, viu? (pausa pequena). Não querendo ser pessimista, viu?

$P$ : Por quê?

A: Por que nós temos os conflitos. E conflitos nem sempre gera o que? Pontos positivos, né? Gera muitos pontos negativos. Nós temos um conflito, por exemplo, de religião, como é que você resolve isso? (pausa pequena). Você não sabe o sentimento no íntimo da pessoa, a gente não consegue prevenir isso. Só através... Logicamente de uma educação que fosse moderada no mundo inteiro, né? Que todos, ééé, eu acho que se todos comungassem da mesma religião, ou então se conseguisse que dentro de religiões distintas respeitar o próximo. Então é muito difícil. Aqui mesmo no Brasil, que as pessoas não são tão ligadas à questão religiosa, se você começa a conversar com alguém e expor seus pontos de vistas, você começa a ter conflitos. E que podem propiciar a violência. Então..."

\section{Análise 7}

No trecho 1 observamos um conceito muito semelhante ao trazido pelo coordenador do curso. Ana conceitua paz como "tranquilidade social". Também considera paz como ausência de violência, ou seja, uma paz negativa, conceito típico do senso comum. Em seguida postula que essa "paz social" seria obtida por meio de pessoas educadas para viver em comunidade e elas promoveriam essa tranquilidade social, tendo também a contribuição do Estado que resguardaria os direitos pessoais de cada um. É um conceito de paz amplo, que envolve coletividade e individualidade, transversalizado pelo fator educação e, talvez, justiça social. No entanto, no trecho 2 , ela faz uma reflexão que vai na contramão do primeiro trecho, afirmando que só seria possível construir uma Cultura de Paz no mundo atual se houvesse uma convergência religiosa e também apresenta incoerência em relação ao conceito de conflito apresentado no item 5. Ao contrário do que defendeu anteriormente aqui diz que os conflitos "geram muitos pontos negativos" e, por isso, seria muito difícil construir a paz. Em poucas palavras, parece que a participante não acredita ser possível a construção de uma Cultura de Paz, pois o mundo em que vivemos se caracteriza pela diversidade, religiosa, inclusive, e, para ela, para viver em paz todos deveriam ser iguais, ou seja, pensarem de maneira semelhante...Aqui não haveria espaço para a negociação construtiva de conflitos! 
8 - Prática policial

Trecho 1 (linhas 374 a 393)

"P: Você acha que de alguma forma, as práticas da polícia envolvem algum tipo de violência? A: Sim! Eu acho que, que, que a atividade, desde a formação nossa, ela tem algumas questões ali que, que gera... isso aí é dentro da minha visão, tá?

$\mathrm{P}:$ Sim, claro!

A: Dentro do meu aspecto, né? Por que pra muitas pessoas isso não é... pode não ser violência... Mas eu acho que quando você pega, por exemplo, um oficial da polícia, e coloca ele pra limpar uma varanda, ou alguma situação nesse sentido aí, isso é uma forma de violência, (pausa pequena) porque você está proporcionando aquela questão que sempre... isso é um grande mal, da nossa instituição, por que a pessoa sai dali e não consegue olhar no olho da pessoa. Porque ela sente...

$P$ : Isso no CFO?

A: Dentro do CFO! Ela se sente subjugada, né? Ela tem que andar com o braço pra trás, isso é uma violência pra mim... Como eu disse, eu acho que é um aspecto negativo, né? Gera uma consequência negativa. Então quando eu falo, dentro da, da APM, né? Se você perguntar isso para os alunos, você vai ter a percepção que a APM não é um lugar bom. Por quê? Por que ela proporciona, muitas das vezes, muitas questões, dentro desse conceito que eu entendo, de formas violenta de tratar a pessoa, né? Então ali você não é digno de estar ali. Vocêêê... se você fosse bom, você não estaria ali, você seria outra coisa, né? Então, isso, é, eu acho que enfatiza muito isso, que Academia é um lugar onde (ééé) eu percebo, queeee, às vezes traz um lado muito violento e negativo com relação a essas questões de tratamento de seus alunos, de seus discentes."

\section{Trecho 2 (linhas 467 a 479)}

"P: De uma forma geral, você acha que a Polícia hoje, mais previne ou mais combate? Ela é mais coerciva, repressiva, ou mais preventiva?

A: Ela é mais repressiva! (pausa pequena) Muito mais! (pausa pequena). A Polícia, na verdade, na maioria das suas acões, é focada na repressão. Se você chegar numa viatura de área e perguntar: o que você faz ao longo das suas 12 horas de serviço? Você vai ter essa resposta. Ela é muito mais.. ela, ela busca a atender a ocorrência: "Oh, vias de fato em determinado local”, "Oh, homicídio", "Roubo a estabelecimento comercial”.

P: Esse trabalho da Polícia Comunitária, você considera como uma prática suficientemente exercida na Polícia Militar?

A: Não! Ele é bem menor...na prática da Polícia. Mas só que aí também... a gente volta a falar na questão da docência, né? Então aqui, parte do pressuposto que eu tenho que começar com as pessoas que estão entrando na Polícia, pra que elas sejam muito mais 
voltadas para o campo preventivo, do que o campo que para o reativo."

\begin{abstract}
Análise 8
Nesse item sobre "Prática policial", ao ser questionada se as práticas da PM envolvem violência a primeira reflexão de Ana é, uma vez mais, sobre o tratamento violento dispensado aos alunos na APM. Segundo sua análise, as formas de tratamento e as falas disseminadas transmitem violência, e geram um ambiente hostil, o que a leva a considerar que a APM "traz um lado muito violento e negativo, com relação a essas questões de tratamento de seus alunos". É, no mínimo preocupante, que a primeira prática considerada por ela como violenta na PM aconteça durante a formação e dentro do próprio curso, que é um ambiente de ensino, pois este deveria ser o primeiro a praticar, e assim transmitir, os valores de uma Cultura de Paz. No trecho 2, Ana considera que a atuação da PM é muito mais repressiva que preventiva e que a prática da Polícia Comunitária, apesar de considerada muito eficiente, ainda é muito pequena no contexto geral da corporação. Ela retoma a questão da formação, argumentando que se deve começar a instruir e formar esse posicionamento de policiamento preventivo, a partir de quem está ingressando na $P M$, pois seria mais fácil consolidar essa prática.
\end{abstract}

\title{
9 - Sugestões e ideias para a PM promover a Cultura de Paz
}

\section{Trecho 1 (linhas 679 a 699)}

"P: Pra finalizar a nossa conversa aqui, que foi bem interessante, gostaria de pedir ideias ou sugestões para que a PM possa contribuir com a Cultura de Paz na sociedade. Sinta-se à vontade de propor tudo que a respeito, certo?

A: É, eu tenho a compreensão que o nosso curso de formação, pra que ele consiga desenvolver isso, nós vamos ter que adotar, éé, um conjunto de fatores, que vai desde esse pressuposto da docência, ou seja, de avaliar quem são os nossos docentes, o nosso corpo docente da APM. Passa também por questões de algumas matérias que são altamente também ééé, eu acho que passa pela carga horária que necessitaria, passa por mudança, uma grade curricular... Uma reformulação da grade curricular, nesse sentido também. $\underline{A}$ valorização (diz com ênfase) dos profissionais que estão ali, ou seja, enaltecer aquelas pessoas que estão ali, mostrar a importância e o papel delas pra sociedade, né? Passa por isso também. Eu acho que a questão da saúde, é importante também, ou seja, enaltecer todo dia isso, o quanto que é fundamental ter uma saúde boa, pra que a gente consiga ser um bom policial. Passa também, eu acho que fundamentalmente por essa questão, trabalhar essas questões técnicas, né? Como instruções de tiro, né? Exaustivos, que é muito importante. As técnicas que são do Procedimento Operacional Padrão (POP). E, 
principalmente (dá ênfase), ééé, mostrar pra aquela comunidade estudantil o tanto que é fundamental nós adotarmos mecanismos hoje que a gente consiga estabelecer parcerias dentro dessa filosofia que a gente traça, de Polícia... Não vou nem falar de comunitária, mas de Polícia! Como é que nós vamos trabalhar hoje pra, pra que a gente consiga, de uma forma inteligente, otimizar o nosso efetivo na prevenção à criminalidade e, quando necessário, combater? Então eu acho que, que essa reformulação, passa por isso."

\section{Análise 9}

As sugestões trazidas por Ana, ao final, resumem seus posicionamentos expressos ao decorrer da entrevista. Insiste na necessidade de bem avaliar os docentes que serão responsáveis pelas práticas e disciplinas, e na valorização da própria profissão e das pessoas que ali estão. São contribuições coerentes que propõem desde reformulação da Matriz Curricular do CFO até práticas envolvendo a Polícia Comunitária. Como instrutora da APM, observamos em Ana um posicionamento crítico a respeito dos processos formativos, das práticas institucionais especialmente em relação ao tratamento que é dispensado aos alunos durante a formação e ressalta a importância da PM trabalhar mais a questão da prevenção. De forma geral, apresenta valiosas contribuições. 


\section{PARTE V}

\section{DISCUSSÃo}

Nesta parte do trabalho propomos uma discussão integrando os principais resultados identificados e analisados a partir dos indicadores obtidos na pesquisa. Para nortear tal discussão estabelecemos alguns pontos de reflexão considerados como mais significativos nas narrativas dos oficiais da Polícia Militar acerca da construção de valores associados à Paz ou à Violência. Notou-se que esses pontos revelam crenças permeadas pela cultura coletiva mais ampla do contexto brasileiro, segundo a qual a paz é vista como algo subjetivo, ligado à existência de harmonia interior e espiritualidade e, eventualmente, algo ligado à tranquilidade social (Branco, 2012; Moreira, 2011). A violência, por sua vez, foi considerada como inerente à condição humana, parte da própria natureza humana, e assumida, por alguns participantes, como prática legítima da Polícia Militar. Os conceitos teóricos aqui trazidos refletem uma série de temas e tópicos profundamente interligados, observados a partir dos diversos exemplos suscitados pela pesquisa, tendo em vista produzir conhecimentos científicos sobre tema estudado.

De maneira ampla, os resultados obtidos por meio das entrevistas individuais indicam que uma visão de paz no sentido construtivo e preventivo é algo ainda distante do pensamento e das preocupações dos participantes. Não é seu costume pensar no fenômeno como um todo, e isto somente ocorre quando existe alguma motivação, ou interesse, associados a situações particulares. Muitas das pausas e hesitações ocorridas durante as entrevistas individuais sugeriram que o tema, ou conceito, presentes nas questões da entrevistadora, não haviam sido, antes, objeto de análise ou reflexão. Isto ocorreu, em especial, com relação aos conceitos de paz e, de maneira surpreendente, com o próprio conceito de violência, fenômeno com o qual, em sua profissão, precisam lidar diariamente. Além disso, como veremos adiante, houve acentuada tendência a avaliar situações de uma maneira mais estereotipada e generalizante. Apenas no contexto do grupo focal foi possível observar um empenho do grupo em analisar de maneira mais ampla, a partir de diferentes ângulos, determinadas questões. Neste sentido, a proposta de discutir com o grupo os dilemas selecionados teve excelente resultado em favorecer o aprofundamento das reflexões apresentadas nas sessões.

Todos atribuem um alto grau de responsabilidade ao Estado pela ausência de paz, considerando que este não cumpre suas obrigações sociais com os cidadãos e, assim, as pessoas não conseguem viver em paz.

As discussões fomentadas nos grupos focais proporcionaram uma enorme riqueza à pesquisa, pois através delas tivemos acesso aos posicionamentos, crenças, 
valores e expectativas que cadetes e oficiais têm (e tiveram) em relação à formação, com críticas elaboradas e percepções bastante aguçadas sobre o processo de internalização da cultura militar. Os dilemas morais propostos foram fundamentais para suscitar vários posicionamentos dos participantes, ora de forma explícita, ora implícita. Surgiram expressão de valores, crenças e julgamento moral, propiciados pela dinâmica da discussão em grupo em relação aos temas investigados. Vejamos, por exemplo, o caso do dilema do assassinato de Maria, a fala do Tenente Gabriel a respeito de seu amigo Paulo, que não quis ajudar a moça. Ele diz que: "Depois, esse Paulo, porque esse Paulo também, vagabundo... 'Não tenho nada a ver com isso não'. Ué, não tem nada a ver?! (indignação)". Já o Cadete Lucas diz que: "Mas ela tava traindo o marido dela do outro lado do morro!".

Tudo indica que a falta de uma análise mais aprofundada de fenômenos sociais complexos como a violência e a construção da paz derivou, tanto no caso dos cadetes quanto dos oficiais, de um poderoso viés individualista vivenciado na sociedade atual e, de certa maneira, também na instituição militar, daí decorrendo a grande dificuldade de ambos os grupos de participantes em enxergar a forte relação existente entre violência e paz social. Em outras palavras, não era evidente para os participantes que a construção da paz poderia conduzir à redução da violência, uma vez que pareciam considerar a violência inevitável e a paz como algo difícil e distante, e não como algo possível de ser, de fato, socialmente construído. A seguir, tópicos específicos para discussão serão destacados.

\section{1 - Paz, Violência e Conflito: conceitos e significações}

O conceito de paz mostrou-se relativamente diversificado entre os participantes, a partir de três enfoques principais: o primeiro refere-se à paz como estado de espírito, algo interior, subjetivo, como citado pelo Tenente Jonas "(...) a paz, ela tem que tá dentro de cada um, porque desse modo a gente vai conseguir exteriorizar alguma coisa de paz pra nossa sociedade". No segundo enfoque, a paz foi definida como ausência de conflitos, ausência de guerra, como destacou o Cadete Moisés "Paz é a ausência de guerra né? Simples, ausência de... de confronto. Paz é ausência de conflito! (...)". E, por último, a paz foi relacionada à tranquilidade social, como citado pelo Capitão Rafael "Paz é a tranquilidade social!", e também pela Capitã Ana "É, aí, a paz ela passa, né? Pelo pressuposto que vem dessa tranquilidade social?". Aqui surpreende o fato de tantos participantes darem ênfase à dimensão individual do conceito em detrimento da noção de paz social, já que sua função profissional se associa à repressão e prevenção da violência, e, ao menos teoricamente, à promoção da paz social. Como outros autores que analisam a questão (Jares, 2002; Branco, 2009; Senna, 2007), Guimarães (2005) 
entende que é necessária uma concepção de paz que envolva mais a qualidade de vida no convívio social do que algo abstrato e etéreo. O autor propõe uma noção de paz de natureza social, muito mais processual, multicultural e dialógica do que um estado de espírito individualista. Afirma que a paz deve ser pautada em ações concretas e não em ideais. Mas esta ideia ainda é incipiente na visão dos participantes.

O Cadete Davi, porém, relacionou a paz a um bem comum "Paz é uma ausência de conflito e cada um respeita o espaço do outro, onde todos pensam num bem comum. Seria pelo trabalho preventivo junto à comunidade (...)". Nesse mesmo sentido, a Cadete Ester argumentou que "(...) A redução desses... dessa criminalidade, a redução dessas manifestações, a redução dessa indignação da sociedade, talvez seria considerada a paz!".

O Capitão Rafael, por sua vez, trouxe uma fala bem instigante: "Só vive em paz quem aprende a lutar!". Mas ele não elaborou sobre como seria esta luta: Lutar contra quem? Contra o que? E como? É interessante ele considerar a luta como meio de se alcançar a paz, mas, seguindo sua análise, esta seria uma luta em vão, porque a paz é, para ele, algo inalcançável, é do plano das ideias. Parece, aqui, considerar ser importante o sujeito ser conformado e apenas cumprir com seus deveres, e não lutar por seus direitos. Sendo ele o coordenador do CFO, preocupa o fato dele não conceber a possibilidade da construção da paz, e não elaborar mais a questão e os grandes dilemas enfrentados pela PM em um nível de maior complexidade e pró-atividade.

A partir dos posicionamentos dos participantes, podemos inferir que seu conceito de paz é bastante heterogêneo, porém muito ligado ao senso comum, não havendo especial reflexão e/ou questionamentos mais aprofundados sobre a temática. Apresentam visões que atribuem responsabilidades ao Estado, de maneira genérica, ou, então, a questões subjetivas, e ignoram a viabilidade do empreendimento de ações concretas para construir a paz.

Galtung (1986), como vimos em capítulo anterior desta tese, propôs o conceito de paz a partir de duas definições: a paz negativa, definida como ausência de violência e organizada a partir de grandes grupos como países, raças e etnias; e a paz positiva, definida a partir da cooperação e integração entre esses grandes grupos. $O$ autor argumenta que o conceito de paz positiva deve ser explorado, uma vez que movimenta as pessoas em seus contextos. A nosso ver, tais ideias seriam de grande interesse das instituições em geral, especialmente das educativas e militares, que em muito podem contribuir para a promoção de interações mais pacíficas entre as pessoas.

Trazendo a discussão para a realidade de nosso país, Balestreri (2003) reuniu, em um livro, diversos estudiosos da paz no Brasil com o objetivo de criar provocações intelectuais visando à superação do discurso banalizado e rasteiro sobre a violência. 
Teve, também, o intuito de pensar criativamente os caminhos da paz, especialmente aqueles que podem e devem ser trilhados pela parceria escola-comunidade-operadores de Segurança Pública, dentre os quais se encontram os policiais militares, participantes desta pesquisa. O autor pondera que o tema da paz está, portanto, longe de ser tão somente um macro-tema sócio-político-econômico, que mira a superação dos grandes conflitos históricos de massa, uma vez que também carrega uma gravidade individual, pessoal, nominal, irrecusável e intransferível. Ou seja, propomos aqui que a questão deve ser abordada e trabalhada nos vários níveis do contexto cultural em que vivemos, do nível micro as interações sociais ao nível meso das instituições até ao nível macro da sociedade como um todo.

A temática da violência aparece de maneira um pouco mais elaborada na fala dos participantes, sendo classificada em física, moral e psicológica. Os participantes consideram a relatividade, o caráter às vezes subjetivo e dificuldade inerente ao conceito, como afirma Cadete Ester: "Qualquer coisa que você fizer, às vezes, pode ser uma violência. É muito relativo!". Também a fala do Tenente Jonas expressa essa diversificação do conceito: "Violência, eu acredito que seja qualquer violação ou agressão de uma pessoa contra outra, ou uma entidade contra outra, de forma física, psicológica ou moral e de forma injusta".

Surgiram reflexões sobre violência legítima e legítima defesa, na qual os participantes inserem grande parte do que consideram como necessária "violência policial". Como bem argumenta o Tenente Gabriel "só precisa utilizar a violência no caso pra se defender... É... Defender terceiros ou se realmente aquela pessoa está ameaçando a sociedade". Por outro lado, eles também reconhecem e repudiam formas de violência que consideram "ilegítima", dentro e fora da Polícia Militar, o que é exemplificado na fala da Cadete Ester: "Acho que aquela surra que eles deram no cara é melhor, porque não vai dá em nada mesmo o processo! Mas acredito que está errado! Também não vai resolver dessa forma (...)". Esta ambiguidade sobre o que é certo ou errado se faz muito presente na fala dos participantes, como argumenta o Cadete Moisés, após observar a Imagem 1 (civil chutando o rosto de um policial militar no estádio de futebol) durante a entrevista individual: "Mas esse confronto é muito antigo e, aliás é... Como é que eu vou dizer? Eu não gostaria que acontecesse, mas infelizmente acontece e vai continuar acontecendo. Parte da torcida vão lá pra brigar mesmo, parte da PM vai lá pra bater mesmo. Já o Tenente Gabriel diz que: "Dependendo da situação que... Não dá nada, ou as leis são muito brandas... Gera esse tipo de frustração no policial que ele descarrega na agressão, na própria agressão. O que não justifica, lógico! (...) Porque a... A cultura, principalmente dessas pessoas de esquerda é de martirizar a policia. É de afrontar a policia". 
O mito de que a violência é inerente à natureza humana, sendo inclusive necessária ao ser humano, aparece explicitamente na fala do Cadete Moisés "Mas 0 homem, eu acho que ele precisa de violência é... É um paradoxo né? É tão contra, mas fala que precisa... O homem precisa um pouco de violência. Qual é o esporte que mais faz sucesso hoje no mundo? Não é o futebol mais... É UFC, MMA, K1, Pride, é luta!". O participante argumenta que a violência é tão necessária ao homem que foi transformada em esporte, sendo legitimada e autorizada a partir de regras pré-definidas, buscando satisfazer essa necessidade que ele considera natural.

Nesse mesmo sentido, um posicionamento bastante contundente e carregado de significados foi observado na narrativa do Capitão Rafael "Violência é um fenômeno atrelado à sociedade. A violência é bíblica, né? A criminalidade, a violência, é bíblica (ênfase). Nasceu lá com Caim e Abel e na minha opinião... Não acaba! Não tem como acabar! Enquanto tiver sociedade vai ter violência". Chama atenção que o coordenador do curso, o mesmo que considera sua função como modelo para a formação dos cadetes, tenha um posicionamento tão determinista com relação à inevitabilidade da violência, desconsiderando as teorias do desenvolvimento humano (Cole \& Cole, 2004).

Rengifo-Herrera (2014) postula que "a violência parece ser muitas vezes considerada uma entidade pré-existente e que emerge, do nada, nas ações do indivíduo" (pág. 23). Assim sendo, na análise do autor, a violência tem sido associada a aspectos evolutivos do ser humano e regula as ações humanas, especialmente nos casos de conflitos e competições. No entanto, este argumento criticado pelo autor apresenta dificuldades para ser mantido, uma vez que desconsidera o papel da cultura que, como sabemos, é o aspecto central e forte promotor e regulador das ações humanas. Estas são sempre carregadas de significações histórico-culturais, e que podem ser orientadas tanto na direção da competição e da violência, quanto na direção da cooperação e da fraternidade (Branco, 2009; 2012).

Com relação à questão do conflito, os participantes o definem como uma divergência de ideias ou interesses, onde um lado não aceita a vontade, ou a opinião, do outro. Bem exemplificado nas definições do Cadete Davi, ele diz que o "conflito é a... É o choque de interesse entre duas pessoas!". Segundo o Tenente Gabriel, "Conflito é uma divergência de opinião, de ideia, de objetivo". Vale salientar que todos os participantes compreendem o conflito como algo positivo ou construtivo, promotor de mudança e, consequentemente, de desenvolvimento, o que nos parece muito interessante e em consonância com a ciência psicológica (Valsiner, 2012). A fala da Tenente Suzana traz essa reflexão "A pessoa entra em conflito com outra pra promover uma mudança que é benéfica (...)". Vale ressaltar, igualmente, o posicionamento do Capitão Rafael "Eu 
entendo que o conflito é uma oportunidade de aprendizado. Quando o conflito é bem resolvido, ou bem mediado, eu entendo que ali há uma possibilidade de crescimento".

Esses posicionamentos nos fazem pensar que os oficiais participantes da pesquisa avançaram significativamente na reflexão e construção da categoria conflito a partir das experiências vivenciadas não só no ambiente militar, mas, principalmente, nele. Ao experienciar inúmeros conflitos advindos da formação e da prática dentro da Polícia Militar, cadetes e oficiais vão sendo formados como mediadores de conflito, uma vez que sua função sempre será de comando, ou seja, eles estarão à frente de grupamentos exercendo uma função de liderança.

Estudos sobre a paz afirmam que o conflito é algo inerente ao ser humano e à sociedade em desenvolvimento. Onde existe relação, relacionamentos, necessariamente haverá conflito e eles podem ser de grande importância na própria promoção do desenvolvimento humano (Valsiner \& Cairns, 1992), particularmente aqueles que os autores consideram como conflitos tipicamente construtivos. Os conflitos constituem algo essencial para o aprimoramento das relações entre os seres humanos e para a construção de uma sociedade mais justa, igualitária, democrática e plural (Melman e cols, 2009).

Portanto, há uma necessidade real de conflitos positivos para gerar desenvolvimento nas pessoas, instituições e sociedades. É da negociação dos inevitáveis conflitos e da mediação pacífica de conflitos que novas alternativas de resolução de problemas emergem, e novas perspectivas podem se abrir. Sendo assim, a capacidade de analisar cada conflito em particular e saber agir no sentido de sua resolução construtiva é fundamental não somente na atuação de policias militares (Moreira, 2011), mas também na atuação de educadores, como mostram os estudos de Cappi (2003), Senna (2007) e Barrios (2009).

\section{2 - Tendência a generalizações}

A generalização é um elemento da lógica e do raciocínio, e compreende dedução baseada naquilo que seu proponente considera correto. Segundo o Dicionário Informal (2015), generalização significa simplificação, disseminação; afirmação geral que não se aplica a todos os casos que se pretende abranger. Na Psicologia, a generalização é considerada uma função cognitiva importante, mas também é vista como perigosa exatamente por não abranger as especificidades dos casos, pessoas e fenômenos que se pretende analisar e avaliar, o que, sem dúvida, leva à interpretações e julgamentos equivocados baseados numa simplificação sumária, superficial e muitas vezes preconceituosa de pessoas, grupos em geral e até mesmo nações. Nesta pesquisa observamos uma tendência dos participantes em generalizar conceitos e 
posicionamentos, como por exemplo, quando solicitados a analisar casos específicos, cadetes e oficiais não se referiam a indivíduos específicos-que poderiam estar agindo com motivações particulares—mas se referiam sempre "à população", "às massas", "à sociedade", "ao bandido", "ao marginal", "ao cidadão de bem" etc. As especificidades de cada pessoa ou mesmo de cada grupo, com suas qualidades diferenciadas, deixavam de ser consideradas.

Como bem caracterizado na fala do Cadete Moisés, essa generalização parece ser ensinada no próprio CFO: “'Ah, o ladrão, o ladrão, o ladrão tem que ser preso, tenho que pegar o ladrão...' Eles usam ladrão no termo genérico, é pra bandido...". O Tenente Gabriel também apresenta uma fala generalizada: "A pessoa que rouba um carro, que põe a arma na cabeça de um pai de família, de uma mãe de família, é... Essa pessoa já tem que ser tratada de uma forma diferente!". Sugere que para ser considerado cidadão de bem, a pessoa tem que ser "pai" ou "mãe" de família... Fica aqui a questão: será que a pessoa que denuncia graves problemas sociais seria um cidadão de bem? Ou o conceito de cidadão de bem seria reservado apenas para o sujeito conformado com o status quo? Como será que percebem o protagonismo da sociedade civil? Enfim, estas são questões difíceis, porém necessárias, para serem discutidas particularmente por aqueles que são responsáveis pela ordem e segurança da população.

Alguns exemplos de tais generalizações foram observados nas análises das imagens e do vídeo mostrado aos participantes, ao final das entrevistas individuais. Segue algumas falas que exemplificam os posicionamentos dos participantes, com referências "à população", "às massas" ou à sociedade", como se todos pudessem ser reunidos em apenas uma categoria. O Tenente Jonas diz: "Eles estavam pichando patrimônio publico, foram é... Abordados pela policia e eles deveriam respeitar isso, mas isso na pratica não funciona! A população não respeita isso...". Tenente Suzana é ainda mais categórica: "É um sentimento assim revoltante, por que a sociedade que está ali representada, ela tá representada por uma massa, uma massa totalmente viciada, que é a forma de resolver o problema do país. (...) Então, como sempre, no Brasil, que é característica do brasileiro, tentar resolver o problema pela via transversa, e não pelo cerne mesmo da questão, que é pela eleição, pela educação do cidadão".

Analisando uma das falas do Cadete Lucas, observamos que ele faz um caminho inverso e desconstrói a generalização que aprendeu a respeito do público que frequenta Estádio: "Você tem uma imagem que eles te passam de algumas pessoas... que ali dentro só tem bandido!". O participante valoriza, portanto, a aprendizagem que teve com a prática, no contato direto com as pessoas, e como isto pode lhe ensinar que é preciso fazer a diferença entre as pessoas, em detrimento do que "ouvia" teoricamente sobre o tema em questão. Ao fazer isto, ele critica a tendência da generalização exagerada e do 
maniqueísmo presente na fala de quase todos os participantes, assumindo um posicionamento que merece destaque dentre todos os entrevistados.

Em resumo, o excesso de generalizações torna-se muito perigoso por estas vêm carregadas de preconceitos e podem direcionar o comportamento das pessoas para direções maniqueístas: todo político é corrupto, todos que vão às ruas para lutar por seus direitos são vândalos e marginais, e até mesmo a preconceituosa generalização de que todo policial é bruto e violento. Na medida em que os participantes da pesquisa vão ampliando suas experiências na profissão, precisam, portanto, estarem atentos para não caírem nessas armadilhas fomentadas pela cultura militar. Como bem argumenta Rengifo-Herrera (2014) "as mensagens canalizadas culturalmente e as experiências fenomenológicas dos sujeitos podem criar ancoragens afetivas sobre esses processos e torna-los gestores/promotores de preconceitos e discriminação de grupos ou pessoas, impulsionando diferenças taxativas entre eles" (pág. 190). E isto precisa ser desconstruído face à argumentações fundamentadas e científicas.

\section{3 - Repressão versus Prevenção}

O tema da repressão foi amplamente discutido a partir das práticas da Polícia Militar. De forma geral, os participantes consideram que as práticas da PM envolvem violência, sendo, portanto, mais repressivas que preventivas. Como argumentado pelo Cadete Moisés "O trabalho policial, ele é um trabalho agressivo! A PM é o primeiro escudo do Estado, ela é o escudo do povo também, mas ela é primeiro escudo do Estado". A Capitão Ana também considera que "Ela é mais repressiva! (pausa pequena) Muito mais! (pausa pequena). A Polícia, na verdade, a maioria das suas ações, é focada na repressão".

A análise do coordenador do CFO, o Capitão Rafael, vai um pouco além " $A$ prevenção ajuda sobremaneira. Mas também ela sozinha não resolve! Não resolve! E a repressão, ela também é necessária! Então eu entendo que as duas andam lado a lado. Juntas! E vai ser difícil desatrelar uma da outra", sugerindo que não há prevenção sem repressão. A Capitão Ana também admite "Ela (prevenção) é bem menor... na prática da Polícia". São posicionamentos preocupantes, por se tratar aqui de um curso de formação de oficiais, e estas crenças podem entrar em contradição com a própria missão da PM: "policiamento ostensivo e preventivo". Talvez a implementação, na prática, de um maior número de atividades de caráter preventivo possa, aos poucos, transformar as concepções hoje ainda prevalentes na PM.

Sobre o trabalho com os alunos abordando o tema da prevenção, o Capitão Rafael ainda afirmou que "Eu entendo que inicialmente, ele é suficiente, é claro que não se esgota em si. Aí depois cada um vai procurando se especializar, vai procurando um 
pouco mais de conhecimento na área né?". Essa fala sugere que a tanto o currículo quanto as demais atividades de formação dão pouca atenção ao tema, atribuindo ao cadete a responsabilidade individual de buscar informações e conhecimentos sobre a temática da prevenção. O participante também admitiu que existem práticas violentas individuais, feitas por alguns policiais, mas as considera como ações isoladas de certos policiais que teriam, segundo ele, "falta de experiência", ou seriam muito "afoitos". O uso deste adjetivo não deixa muito claro o que ele quer dizer, mas o certo é que ele não usa em nenhum momento adjetivos como "violento", "impulsivo", ou "destemperado" etc, sugerindo que este tipo de policial não existe na corporação. Para ele, parece que todos os policiais experientes são equilibrados e justos na aplicação da força.

O Cadete Davi corrobora essa ideia de que apenas policiais mal preparados tenham práticas violentas "(...) acho que... eu acredito que envolve por parte daqueles policiais mal preparados". Ele defende a prevenção, mas considera que "tem situações pontuais que não tem como você prevenir! Por exemplo, o homicídio passional... Um homicídio passional é algo que não tem como prevenir!".

A dicotomia entre repressão e prevenção parece ser um entrave não apenas no processo formativo dos policiais militares, mas, sobretudo, uma dificuldade em sua prática profissional. Tendo como base a fala do coordenador do CFO, percebemos, porém, uma tendência a minimizar a questão da ausência de uma preparação para a prevenção, com o argumento de que a relação entre prevenção e repressão da violência é discutida de maneira satisfatória durante o curso: (...)inicialmente, (o tema) é suficiente, é claro que não se esgota em si. Aí depois cada um vai procurando se especializar, vai procurando um pouco mais de conhecimento na área né?". O coordenador, então, completa: "Olha, não é ensinada violência em momento algum nos cursos da PM". Parece aqui ter sentido necessidade de explicar que, apesar do fato de não discutirem muito sobre a prevenção, o curso não "ensina" a violência.

$\mathrm{Na}$ prática, a prevenção é reconhecida por todos os participantes sob a forma de alguns programas da PM, especialmente o PROERD e Policiamento Comunitário, que, aliás, é uma filosofia de trabalho. Todos entendem que são necessários mais programas que visem a prevenção e uma consequente construção da Cultura de Paz por meio da atuação da Polícia Militar, no entanto parece que o tema ainda é novo para os participantes, pouco discutido, e as sugestões apresentadas são muito pouco concretas neste sentido.

Parece haver aqui uma grande contradição: por um lado, argumentam que não são ensinadas práticas de violência nos cursos de formação; por outro, todos reconhecem que as práticas da PM envolvem violência. Além disso, se a prevenção não é incentivada, como reduzir a violência? Consideramos, a partir disso, que as práticas da 
PM que envolvem violência são adquiridas com a própria experiência, ao longo das trajetórias desenvolvimentais de cada sujeito dentro da corporação, a depender dos exemplos e modelos profissionais adotados durante o curso e do local em que o oficial irá trabalhar após sua formatura.

\section{4 - Valores Humanos e Moralidade: posicionamentos diante dos dilemas}

\subsection{1. "De quem é a culpa?"}

A partir dos dilemas morais apresentados como proposta para discussão nos grupos focais, algumas questões foram observadas. A "História de Maria" (o primeiro dilema) suscitou uma discussão acirrada entre os Cadetes sobre a responsabilidade individual de cada personagem. Todos os Cadetes consideraram "os bandidos" como maiores culpados pela morte de Maria; a Cadete Ester defendeu veemente que seria o marido o segundo culpado, por ter abandonado a esposa. Os demais participantes argumentaram que o segundo culpado seria a própria Maria, seguindo o princípio da vitimologia, dizendo que ela assumiu o risco por passar em um local perigoso. Este foi o foco de toda a discussão do grupo de Cadetes, que não chegaram a um consenso sobre o escalonamento da culpa, proposto pela pesquisadora como maneira de incitar a discussão. No entanto, a discussão foi bastante rica e revelou como os valores de violência e a responsabilidade de cometê-la estão bem definidos para o grupo, que atribuiu a maior culpa aos bandidos. Os demais personagens da história estiveram ocupando posições diferentes de acordo com o julgamento sócio-moral individual de cada um.

No grupo dos Tenentes, no entanto, surpreendeu o fato de que estes não colocassem os bandidos como sendo os principais culpados durante um bom tempo da discussão! A discussão inicialmente girou em torno de uma possível traição, o que transformaria Maria na maior responsável por sua própria morte. Esse posicionamento foi defendido, especialmente, pela Tenente Suzana, mas todos os participantes pareceram ignorar a culpa dos bandidos pela morte de Maria. Ao que tudo indica, o julgamento moral da mulher sugere que sua morte configura uma espécie de punição pelo fato da suposta traição. O segundo tema a ser debatido e questionado pelo grupo envolveu a responsabilidade pela proteção da mulher, sendo esta atribuída por um dos participantes ao marido, e, por outro, à polícia. O auge da discussão ocorreu quando, finalmente, um dos participantes chamou a atenção dos demais para o fato de que foram os bandidos que mataram Maria, ou seja, eles é que foram os autores do crime. Falou o Tenente Gabriel: "Mas isso que eu quero que você entenda, a culpa, a primeira culpa é do 
bandido que matou! Gente, que é isso? Vocês estão querendo tirar a culpa do assassino? A culpa é dele! Se ele não quisesse matar ela, 'não vou matar você, pode passar...' A culpa foi dele!" (fala com ênfase e indignação).

Tenente Suzana, por exemplo, ao dizer que o dilema "Confunde nossa mente!", destaca o quanto os participantes tiveram dificuldade em superar a tendência de culpar a vítima, naturalizando, assim, o crime e a violência, e julgando o valor "moral" da conduta das vítimas. Depois disso, o posicionamento do grupo foi convergindo até chegar a um consenso no escalonamento de culpa. Vale, portanto, salientar que, apesar dos tenentes terem, a princípio, mais experiência com a ocorrência de crimes, no momento de julgar a responsabilidade das pessoas envolvidas acabaram dando prioridade a questões relacionadas a uma moral sexual, e relacionada ao gênero, em detrimento do princípio moral da preservação e respeito à própria vida. Isto, de certa maneira, gera uma preocupação.

Shweder e Much (1991) argumentam que as crenças morais têm sua origem ontogenética nas mensagens e significados implicitamente transmitidos a partir da fala, da conversação, do discurso e das práticas cotidianas. Os autores sugerem que alguns julgamentos sócio-morais são aprendidos por razões que fazem sentido para vários grupos, ao passo que os julgamentos sócio-morais próprios de cada cultura existem porque fazem sentido apenas para determinados contextos. Assim, considerando as narrativas dos participantes, observamos que os posicionamentos por eles adotados na "História de Maria", referem-se não apenas a valores individuais, mas também a valores em construção no contexto militar, em relação à culpa.

\subsection{2. "Tortura Ética": a fabricação de um conceito ou a noção de que "na prática a teoria é diferente'?}

A questão da tortura foi algo que veio à tona a partir do dilema "A Bomba e o Policial". No grupo dos cadetes o uso da tortura surgiu naturalmente como uma das primeiras opções para obter informações do terrorista apreendido. Vale ressaltar o conceito do "Direito Penal do inimigo", trazido por eles como uma forma de legitimar os seus posicionamentos. A teoria que discute este direito foi enunciada por Günther Jakobs, pensador alemão que a sustenta desde 1985 com base em políticas públicas de combate à criminalidade interna e/ou internacional. A teoria do "Direito Penal do Inimigo" sustenta-se sobre três pilares: "(a) antecipação da punição; (b) desproporcionalidade das penas e relativização e/ou supressão de certas garantias processuais; (c) criação de leis 
severas direcionadas à terroristas, delinqüentes organizados, traficantes, criminosos econômicos, dentre outros, dessa específica engenharia de controle social”11.

De forma geral, essa teoria visa a prática do Direito Penal que, segundo Matos (2009), separa os delinqüentes e criminosos em duas categorias: os primeiros continuam com o status de cidadão e, caso infringirem a lei, teriam ainda o direito ao julgamento dentro do ordenamento jurídico estabelecido e poderiam voltar a ajustar-se à sociedade. A segunda categoria seriam os chamados de "inimigos do Estado" e, a estes, caberia um tratamento rígido e diferenciado. Os inimigos perdem o direito às garantias legais. Não sendo capazes de se adaptar às regras da sociedade devem ser afastados, ficando sob a tutela do Estado, e perdendo o status de cidadão (Matos, 2009). O exemplo mais visível desse "inimigo" é a figura do terrorista, cada vez mais comum na atualidade.

Parece-nos provável que a relação entre o dilema proposto em "A Bomba e o Policial" e o "Direito Penal do Inimigo", tenha sido feita por se tratar de um terrorista. Também chama atenção o neologismo "Tortura Ética" citado pelo grupo. Segundo os participantes, seria a justificativa pela retirada dos direitos legais do terrorista. Uma vez que ele se colocou como inimigo do Estado, seria "ético" utilizar a tortura como método para obter a informação desejada e salvar as milhares de vidas em risco.

A discussão do grupo girou em torno do valor de "uma vida" em detrimento de "várias vidas" em risco, e a legitimidade da utilização da tortura seria, portanto, pautada na referida teoria com o objetivo de preservar "várias vidas". A fala do Cadete Moisés exemplifica essa ideia: "Entre a vida dele e a de centenas, a de centenas prevaleceria né?". Também o Cadete Davi concorda: "A gente não pode discutir a vida dele, porque a vida dele não tá em discussão (...). O que tá em discussão é integridade física, psicológica e etc.".

Os Cadetes utilizaram o termo "tortura ética", explicado no contexto do grupo focal como um neologismo para reforçar a justificativa da ação, como diz o Cadete André: "O objetivo dessa tortura não é a tortura em si, fazer o mal, entendeu? Mas obter algum tipo de informação que vai salvar vidas! Em seguida, o Cadete Davi completa: "É uma 'Tortura Ética!'”.

No grupo dos Tenentes, porém, a discussão foi mais cuidadosa com relação a questão da tortura, questão sugerida pela situação da bomba e do terrorista. Os participantes apresentaram posicionamentos mais incertos e flutuantes, e apenas Tenente Suzana apresentou um discurso mais consistente. Ela, inicialmente, afirma que não tem jeito, que a lei não tem brechas e teria de ser respeitada, mesmo com a probabilidade da morte de muitas pessoas:

\footnotetext{
${ }^{11}$ Fonte: www.wikipedia.org
} 
Suzana: Ah gente! Não tem isso de 'matar milhares de pessoas...' Isso é legalista, é a lei, então a lei que manda!

Jonas: A gente trabalha com recompensa... Dá recompensa pra ele, "Oh, se você falar aonde tá..."

Suzana: Cai nessa não! É legalidade, é a lei! Se ele não falar problema dele!

Gabriel: E deixa explodir tudo? Não... Não... Eu acho que tem uma inversão de valores aí... O pró-societário... Garantia da segurança da sociedade, da ordem pública que predomina sobre o direito individual dele! Pra mim tem que ser assim, como é nos Estados Unidos lá... Como eles tratam os terroristas lá? Os suspeitos de terrorismo? Justamente, há uma inversão... No caso especifico de terrorismo, é o pró-societário, ele perde as garantias individuais...

Suzana: Gabriel, eu sei. A lei, a lei ela é imoral! Totalmente imoral, a gente sabe disso! Tem a moral e a ética. Ela é imoral né? A ponto dela falar assim: "prende e pronto". Só que a gente sabe que não é assim na prática!

A fala da Tenente Suzana "A lei, a lei ela é imoral! Totalmente imoral, a gente sabe disso!" é comumente utilizada no meio policial, para expressar a indignação quanto a questões que a Lei exige ou permite, mas que os oficiais não consideram corretas, e por isso afirmam que a lei seria "imoral". Suzana se queixa aí da imoralidade da lei, mas, no geral, os participantes não assumiram nenhuma postura categórica em relação à atitude que deveria ser tomada para obter a informação do terrorista, sendo visível sua esquiva em relação ao tema da tortura. A tortura aqui aparece aqui claramente como um tabu; aquilo que pode eventualmente ocorrer, mas sobre o que não se fala. $A$ fala do Tenente Gabriel sumariza esta dificuldade, quando diz:

Pela sociedade, pela visão particular acho que seria assim, ele deveria falar né? Não importa o meio. É uma situação. Agora profissionalmente falando, tendo em vista todo o ordenamento jurídico da sociedade, é fazer nada... (Gabriel, 2015)

Percebemos, assim, duas tendências distintas: enquanto o grupo dos Cadetes fala e se posiciona abertamente em relação a tortura considerando-a como opção para o caso, o grupo dos Tenentes se esquiva, argumenta que isto não seria legal, geraria problemas para eles, e, então, tratam o tema como um tabu. Em nossa análise, este posicionamento foi aprendido, desenvolvido e consolidado com a formação e com a atuação prática dos Tenentes nas atividades de comando, que lhes fazem ver a grande complexidade e as dificuldades envolvidas no dilema, o que ainda não aconteceu com os Cadetes, com apenas três meses na APM.

Em nossa análise, a diferença observada aqui entre os dois grupos em termos de posicionamentos, crenças, expectativas e valores, diante dos dois dilemas apresentados, se deve às diferentes experiências, nível de informação e vivência no contexto militar existentes entre os dois grupos de participantes. Por um lado, os Cadetes são mais objetivos e mais teóricos, e por outro, os tenentes tiveram menos profundidade de análise no caso de Maria, mas estavam mais cientes do grande problema, ou impasse, que a questão da tortura coloca para os profissionais de segurança pública. 


\section{5 - Duas faces do militarismo: sedução versus boçalidade}

As questões que envolvem a "cultura militar" foram, sobremaneira, ressaltadas nas narrativas dos participantes. Nas entrevistas individuais e também no grupo focal, percebemos uma dualidade que envolve, por um lado, a sedução pelo poder e autoridade dos quais a PM é investida, e de outro, a boçalidade e os abusos decorrentes da hierarquia inerente ao sistema. A fala do Cadete Moisés explicita bem a questão da sedução: "E depois a gente vai conhecendo as funções, que... são... Muito interessantes também. É um poder, que de certa forma... Que seduz né?".

A questão do abuso de autoridade e grosseria no tratamento dos subordinados envolve a hierarquia, um dos pilares do militarismo, também citada de forma dicotômica, sendo considerada algo bom e ruim, ao mesmo tempo. A Cadete Ester ressalta que "Eu acho que é a maior qualidade e poderia ser até o maior defeito né? Que seria a hierarquia! Que é uma das coisas que ajudam a ser um bom oficial, mas dependendo da ponderação de como vai ser... Também prejudica!". De uma forma geral, Cadetes e Tenentes criticaram os excessos cometidos com base na hierarquia e elogiaram posturas individuais de pessoas em altos postos da corporação que agem com polidez, justiça e comedimento. O Cadete Moisés relata "É ver pessoas que estão na parte de cima, no comando, ou seja, em cima na hierarquia... E com humildade, tranquilidade...". Isto, na visão dos Cadetes entrevistados, gera grande admiração.

Recentemente foi realizada pela Secretaria Nacional de Segurança Pública (prelo), uma pesquisa sobre a 'hierarquia' no contexto nacional, tendo como participantes policiais militares pertencentes a quatro Polícias Militares das diferentes regiões do país. A partir desse estudo, observou-se que muitos participantes, ao analisarem as questões que envolvem a incorporação dos princípios do militarismo em sua formação, apresentaram uma visão crítica, considerando a hierarquia como algo ultrapassado. Por outro lado, a pesquisa também corrobora as narrativas dos Tenentes e Cadetes participantes desta pesquisa, que consideram valores como obediência e respeito, adquiridos, especialmente, durante a formação, como importantes e necessários para 0 trabalho policial.

Nesse sentido, parece haver um consenso entre o que os participantes consideram como práticas positivas no militarismo: respeito e disciplina, e o que consideram negativo: boçalidade e mau uso da hierarquia. Tanto nesta pesquisa como no estudo citado, os participantes consideram que o processo formativo precisaria ser melhor elaborado visando mais a atividade policial em si, e focando menos nos rituais e na simples manutenção de uma cultura militar que, em alguns pontos, deveria ser superada por ser desnecessária (humilhação de subordinados, perda de tempo com algumas práticas e exposição a exercícios cansativos ou excessivos. 


\section{6 - A Formação: significações, competição e lealdade}

A formação compreende um dos processos desenvolvimentais do ser humano que ocorre a partir de múltiplos fatores, envolvendo desde aspectos individuais e subjetivos até normas gerais e padronização de grades curriculares. Nas Polícias Militares, a formação é orientada para o treinamento técnico de funções específicas, ao mesmo tempo em que propõe a adaptação e assimilação de valores e práticas que constituem a cultura militar.

Apesar da Matriz Curricular do CFO estar em constante atualização, como bem colocou o coordenador do curso, na fala dos participantes apenas duas disciplinas discutem com mais especificidade a temática Violência e Paz: Polícia Comunitária e Direitos Humanos. Ao que tudo indica, não contemplam uma reflexão profunda sobre o tema, não propõem debates e não trabalham com a proposta de dilemas. Outro ponto que vale ressaltar é o fato dos participantes não mencionarem a Cultura de Paz e a negociação construtiva de conflitos como propostas para diminuição da violência, ou seja, estas temáticas aparentemente não abordadas no CFO.

A respeito das questões levantadas sobre a formação, o grupo dos Cadetes considerou, como ressalta o Cadete Moisés, que "A orientação é boa, mas tem instrutores e instrutores né? (...) Então, a formação depende... aqui depende do comando!". Esta fala é um tanto preocupante, pois apesar de haver uma Matriz Curricular padronizada, a formação fica atrelada a questões subjetivas de quem está no comando. E comando aqui se refere desde o Comandante da APM até o instrutor de cada disciplina.

Outro ponto a ser destacado envolve o significado da palavra formação que, na fala do Cadete André, seria "a palavra chave aqui é adestramento!", o que foi confirmado pelo Cadete Moisés "Nós somos adestrados a acostumar com o individual, com a tradição... Pra até... Até levar isso conosco". A Cadete Ester, também diz que "Por exemplo, esse desfile aqui todos os dias, eu acho um absurdo! E o que me mostra que o foco aqui é o militarismo, a tradição". Todas essas falas demonstram um alto grau de percepção do "currículo oculto" (Branco, 1993) que acaba sendo veiculado nos cursos de formação da PM, onde algumas atividades, como alguns rituais e solenidades, foram considerados experiências positivas, marcantes e emocionantes, enquanto outras práticas, como o excesso de ordem unida e o mau uso da hierarquia, foram alvo de duras críticas.

Na pesquisa realizada pela Secretaria Nacional de Segurança Pública - Senasp (no prelo), os participantes consideraram que o poder e o uso da força são características que fundamentam a formação na PM, especialmente com aspectos inerentes à "iniciação para o serviço militar". A pesquisa também concorda com o grupo dos Cadetes, relatando 
que a formação militar funciona como um "adestramento, tendo grande foco na vivência da disciplina" (pág. 54).

O grupo dos Tenentes, considerando a mesma temática da formação, apresentou um posicionamento crítico, no qual os participantes fizeram ampla discussão, que envolveu desde o que consideram como o mais importante para a formação de um oficial, até o sentimento construído a partir de situações consideradas desagradáveis. Os posicionamentos foram diversificados. Os Tenentes Gabriel e Jonas apresentaram posturas mais defensivas, porém críticas e com considerações relevantes. A Tenente Suzana, por sua vez, apresentou posicionamentos ainda mais críticos voltados para a má condução das regras e normas propostas pelo militarismo "É necessário! O problema que pelo fato do militarismo, as pessoas ali, elas se transformam porque esse poder é dado a ela, e ela acaba exacerbando!".

Outro ponto ressaltado pelo grupo diz respeito à competição exagerada entre os colegas de curso. O Tenente Gabriel pontua: "O maior problema, vou falar pra senhora, são duas coisas que me estressou. Assim, que eu ficava estressado no CFO. Olhar o companheiro como adversário!". Essa é uma das situações. Nós, nossos amigos, mas ao mesmo tempo que nós somos amigos, nós somos adversários porque vale nota e futuramente vai ter uma classificação. Então assim, isso pra mim é terrível! Competir 24 horas com o seu colega!". A Tenente Suzana concorda com o colega: "Sim, isso daí é o mais valorizado: ser o zero um e zero dois. Isso aí é a farsa! É uma falsidade! A pessoa prega companheirismo, amizade, ao mesmo tempo em que aqui... Igual eu mesma, eu fui jogada pro ultimo, pra rela. (...) A gente se sente ridicularizado! O instrutor chega na sala e fala: "a galera do fundão ali, são os últimos colocados da rela!". O Tenente Jonas também corrobora estes posicionamentos: "É desgastante!". Considerando que os participantes desse grupo já estão formados há dois anos, essas falas nos direcionam para algo que foi negativamente marcado na experiência da formação deles, tendo um valor afetivo carregado de muita significação.

Sendo a lealdade um valor muito valorizado na cultura militar, a competição exagerada pelos primeiros postos, relatada pelos Tenentes, acaba fazendo um caminho inverso na construção desse valor. Sendo a competição a forma de avaliação imposta e fomentada pela instituição, o processo formativo se mantém nessa contradição. Como alguém conseguiria ser leal com seu concorrente? A canalização cultural da competição e do individualismo, neste caso, coloca sérios entraves ao desenvolvimento da cooperação e da lealdade. Como afirmam Branco, Manzini \& Palmieri (2012, p. 96), a canalização cultural é "o processo, segundo o qual, a cultura promove o desenvolvimento em determinadas direções por meio de sugestões sociais implícitas (indiretas) ou 
explicitas (diretas)". Daí, tais regras, avaliações e sugestões sociais precisariam ser revistas, tendo em vista a promoção coerente de valores.

Outro ponto a ser destacado, faz referência à forma como os instrutores são selecionados—ou não-para ministrar as disciplinas nos cursos de formação da PM. A Capitão Ana faz uma reflexão importante "Então assim, e aí é onde eu falo que eu acho que a docência, ela é uma questão de, de, de, na verdade a pessoa tem que ter, ser vocacionada, e muitas das vezes as pessoas que estão ali, não tem talento nenhum pra ser docente, né? Então, isso também é um grande problema, da, da, da nossa, da nossa, ééé, do nosso curso de formação". Na sua concepção, a melhoria da formação depende muito da escolha dos docentes, da sua vocação, experiência e práticas pedagógicas. Tal observação também foi realizada na forma de crítica pelos participantes da pesquisa da Senasp (no prelo): "(...) a falta de qualificação dos instrutores para o ensino; geralmente são oficiais sem formação pedagógica, comprometendo os aspectos acadêmicos e de conteúdo dos cursos (...)".

Sendo assim, as significações que envolvem a formação, expressas pelos participantes, revelam pontos que fundamentam a construção de valores próprios da cultura militar, ao mesmo tempo em que bloqueiam outros, de maneira contraditória. Os resultados apontam, portanto, para a necessidade de uma identificação e discussão acerca de tais contradições, no sentido de que se promova, ao longo do curso, os objetivos da formação militar em termos de valores, habilidades e competências para o exercício da profissão. 


\section{PARTE VI}

\section{CONSIDERAÇÕES FINAIS}

A partir dos resultados da pesquisa e das reflexões teóricas e conceituais aqui discutidos, compreendemos que tanto a paz quanto a violência são valores culturalmente construídos e fortalecidos durante as trajetórias de vida individual e da coletividade. Assumir os conflitos como potencialmente construtivos e media-los de uma forma inteligente, é um bom caminho para evitar a expressão da violência.

A transformação da cultura da violência para uma Cultura de Paz exige desconstruir a legitimidade do uso da violência como instrumento de resolução de conflitos. Melman e cols. (2009) concordam que é preciso reconhecer a violência como algo que fere a dignidade humana, tanto da vítima quanto do agressor. Ou seja, todos acabam sendo prejudicados de alguma forma.

Devemos considerar que a instituição estudada cuida da segurança da sociedade, ao mesmo tempo em que forma profissionais, constrói valores e cria uma cultura que, por meio das diversas redes de interações, irá influenciar muitas pessoas. Ao prover segurança aos cidadãos, esses profissionais defrontam-se com situações dilemáticas permeadas de tensão, que os expõe constantemente aos limites da própria condição humana, do convívio com a violência e a agressão, com a coisificação do outro e com o permanente dilema 'dominação-submissão' em situações de risco e perigo. Nesse sentido, no exercício de sua função, os policiais militares vivenciam cotidianamente esse paradoxo, pois caminham constantemente na interface entre a paz e a violência.

Os resultados da pesquisa nos permitiram considerar que a formação do oficial, bem como sua atuação prática na atividade fim da Polícia Militar, tende a promover a competição ao mesmo tempo que busca construir lealdade; fomenta valores voltados para paz e mediação de conflitos, mas ainda faz uso de práticas vistas como desrespeitosas e excessivas; trabalha a prevenção da violência, mas na prática enfatiza muito mais a repressão; constrói valores da cultura militar, alguns capazes de seduzir e estimular o Cadete, mas outros, como o autoritarismo rude e excessivo, capazes de provocar sérias críticas. Para os participantes, ingressar na carreira de Oficial da PM foi um evento semiótico marcadamente importante em suas trajetória de desenvolvimento, carregados de significados e ainda em fase de elaboração.

Observamos, também, que os valores da cultura militar são disseminados e coconstruídos tanto por meio de disciplinas que compõem a grade curricular do CFO, quanto por atividades complementares, que envolvem solenidades, formaturas militares e 
o "currículo oculto", ou seja, conteúdos implícitos transmitidos ao longo da formação (Branco, 1993).

Tendo sido a pretensão desta pesquisa contribuir para identificar e analisar aspectos da formação militar no que diz respeito a questões de violência e promoção da paz, acreditamos haver alcançado este objetivo. Estes conhecimentos, por sua vez, podem contribuir para que a Polícia Militar avance na compreensão dos processos de construção de valores, avaliando possibilidades e aperfeiçoando seus referenciais teóricos e práticos, a fim de subsidiar atuações profissionais que corroborem as necessidades urgentes da sociedade atual.

Buscar a promoção e construção de valores de paz em um grupo específico como a PM, através de ações práticas, parece-nos um excelente caminho para uma Cultura de Paz. No entanto, compreendemos que o estudo dessa temática demanda, ainda, muitas pesquisas e muitos esforços no sentido de adequa-los a uma realidade social complexa.

As mudanças culturais ocorrem de forma processual, sendo sedimentadas à medida que são assimiladas e, sobretudo, aprovadas pelas pessoas em seus contextos específicos. Na Polícia Militar esse processo é ainda mais complexo, por ser uma instituição tradicional pautada em hierarquia e disciplina, na qual, muitas vezes, as pessoas apenas executam ordens sem ter a oportunidade de questioná-las ou buscar melhores opções para realizá-las. No entanto, acreditamos que mudanças na cultura institucional podem favorecer a integração entre os vários níveis hierárquicos, com a construção de um ideal de autoridade, e mediante a prática de diálogos mais cooperativos.

Buscamos, com esse estudo, trazer uma contribuição para o meio acadêmico e, também, para a instituição Polícia Militar, postulando que os policiais militares, sobretudo os Oficiais, têm uma grande responsabilidade e importância na construção da Cultura de Paz. Desenvolver esta consciência e compreensão, bem como as habilidades e competências necessárias para serem efetivos agentes promotores da Cultura de Paz, é fundamental. Em outras palavras, nossa contribuição com este trabalho é dupla: por um lado, pretendemos avançar teórica e metodologicamente na compreensão dos processos de significação da construção de valores para paz e violência, desenvolvendo conhecimentos capazes de fornecer subsídios para uma metodologia de capacitação profissional a ser utilizada no Curso de Formação de Oficiais. Por outro, pretendemos, a partir deste estudo, contribuir para outros programas e políticas públicas na área da Segurança Pública que venham a ampliar a atuação preventiva dos policiais militares no sentido de atuar e contribuir para a construção de uma Cultura de Paz. 


\section{PARTE VII}

\section{REFERÊNCIAS}

Abbagnano, N. (2000). Dicionário de filosofia. São Paulo: Martins Fontes.

Adams, D. (2005). Cultura de Paz e Cultura de Guerra. Folha de São Paulo. Acessado dia 10/06/2014, disponível em http // www1.folha.uol.com.br/fsp/mundo/ft230120051 0.htm

Bakthin, M. (2003). Estética da criação verbal. Trad. Maria Ermantina Galvão. 3. ed. São Paulo: Martins Fontes.

Balestreri, R. (2003). Consciência moral e construção da Paz. Em R. Balestreri (Org.). Na inquietude da Paz. Passo Fundo/RS: Ceduc.

Barrios, E. (2009). Desenvolvimento moral e práticas pedagógicas na educação infantil: um estudo sociocultural construtivista. Dissertação de Mestrado, Universidade de Brasília, Brasília.

Barrios, A. M., \& Branco, A. U. (2008). Desenvolvimento moral: Novas perspectivas de análise. Psicologia Argumento, 25 (51), 413-424.

Bauer, M. W. \& Gaskell, G. (2002). Pesquisa qualitativa com texto, imagem e som: um manual prático. Petrópolis: Vozes.

Berkowitz, L. (1964). Development of motives and values in a child. New York: Basic Books.

Besabe, N. \& Valencia, J. (2007). Culture of Peace: Sociostructural Dimensions: Cultural Values, and Emotional Climate. Journal of Social Issues, 63, 405-419.

Berger, P. L. \& Berger, B. (1994). O que é uma instituição social? Em: M Foracchi \& J. Martins. Sociologia e Sociedade (pp. 238-256). Rio de Janeiro: L T C Editora.

Bergman, R. (2004). Identity as motivation: Toward a theory of the moral self. In: S. Lapsley \& D. Narvaez. Moral Development, self and identity. New Jersey: Lawrence Erlbaum Associates.

Bohm, D. (2005). Diálogo: comunicação e redes de convivência. São Paulo: Palas Athena.

Brasil, Constituição (1988). Constituição da República Federativa do Brasil. São Paulo: Saraiva.

Branco, A. U. (2012). Values and sociocultural practices: pathways to moral development. In: J. Valsiner (Org.). The Oxford handbook of cultural psychology (pp. 109-132) New York: Oxford University Press.

Branco, A. U. (2009). Cultural practices, social values, and childhood education. In M. Fleer, M. Hedegaard \& J.Tudge (Orgs.), World Yearbook of Education 2009 - 
Childhood studies and the impact of globalization: Policies and practices at global and local levels (pp. 44-66). Londres: Routledge.

Branco, A. U. (2006). Crenças e prática culturais: coconstrução e ontogênese de valores sociais. Revista Pro-Posições, 17, 139-155.

Branco, A. U. (1993). Sociogênese e canalização cultural: contribuições à análise do contexto das salas de aula. Temas em Psicologia, 3, 9-17.

Branco, A. U., Palmieri, M. \& Gomes Pinto, R. (2012). Cultural Practices and Value Constructions: The Development of Competition and Individualism Within Societies. In: A. U. Branco, \& J. Valsiner (Orgs.). Cultural Psychology of Human Values, (pp. 3162). Charlote, NC: Information Age Publishing.

Branco, A. U. \& Lopes de Oliveira, M. C. (2012). Diversidade e Cultura de Paz: a integração necessária. Em: A. U. Branco, \& M. C. Lopes de Oliveira (Orgs.). Diversidade e Cultura da Paz na escola, (pp. 11-17). Porto Alegre: Mediação.

Branco, A. U., Manzini, R. G. \& Palmieri, M. (2012). Cooperação e promoção da paz: valores e práticas sociais em contextos educativos. Em: A. U. Branco, \& M. C. Lopes de Oliveira (Orgs.). Diversidade e Cultura da Paz na escola, (pp. 95-123). Porto Alegre: Mediação.

Branco, A. U. \& Valsiner, J. (2012). Cultural psychology of human values. Charlotte, NC: Information Age Publishers.

Branco, A.U. \& Valsiner, J. (2004) Communication and metacommunication in human development. In: Brokmeier, J. \& Carbaugh, D. (orgs.). Narrative and identity: Studies in autobiography, self, and culture, 39-58. Amsterdam \& Philadelphia: John Benjamins.

Branco, A. U. \& Madureira, A. F. A. (2001). A pesquisa qualitativa em psicologia do desenvolvimento: questões epistemológicas e implicações metodológicas. Temas em Psicologia da SBP, 09, 63-75.

Branco, A. U. \& Valsiner, J. (1997). Changing methodologies: a co-constructivist study of goal orientations in social interactions. Psychology and Developing Societies, 9, 3564.

Branco, A. U. \& Mettel, T. P. L. (1995). Canalização cultural das interações criançacriança na pré-escola. Psicologia: Teoria e Pesquisa, 11, 13-22.

Bruner, J. (2001). A cultura da educação. Porto Alegre: Artmed.

Bruner, J. (1997). Atos de significação. Porto Alegre: Artmed.

Callado, C. V. (2004). Educação para a paz: promovendo valores humanos na escola através da educação física e dos jogos cooperativos. São Paulo: Wak. 
Camic, P. M., Rhodes, J. E. \& Yardley, L. (2002). Qualitative research in psychology: Expanding perspectives in methodology and design. Washington, DC: American Psychological Association.

Camps, V. (2005). El concepto de virtud pública. In: P. Galán (Org.). Democracia y virtudes cívica (pp. 17-40). Madri: Biblioteca Nueva.

Cappi, R. (2003). Paz nas escolas: o papel da polícia. Em R. Balestreri (Org.). Na inquietude da Paz. Passo Fundo/RS: Ceduc.

Cole, M., \& Cole, S. (2003). O desenvolvimento da criança e do adolescente. Porto Alegre: Artmed.

De Rivera, J. (2004). Assessing the basis for a culture of peace in contemporary societies. Journal of Peace Research, 41, 531-548.

De Rivera, J. (2009). Assessing the peacefulness of culture. In: J. De Rivera, Handbook on building cultures of Peace (pp. 89-103). Worcester, MA: Springer.

Dicionário Aurélio da Língua Portuguesa. Acessado em 04/12/2015, disponível em http://www.dicionariodoaurelio.com/

Dicionário Informal da Língua Portuguesa. Acessado em 04/12/2015, disponível em http://www.dicionarioinformal.com.br/viol\%C3\%AAncia/

Dusi, M. M. (2006). A Construção da Cultura de Paz no Contexto da Instituição Escolar. Dissertação de Mestrado, Universidade de Brasília, Brasília-DF.

Eisenberg, N. Fabes, R., \& Spinrad, T. (2006). Prosocial development. In W. Damon, R. Lerner, \& N. Eisenberg (Org.). Handbook of child psychology (pp. 646- 718). Hoboken, NJ: Wiley.

Freitag, B. (1997). Itinerários de Antígona. São Paulo: Papipus Editora.

Freud, S. (1968/1933). New introductory lectures on psychoanalysis. London: Hogart.

Galán, P. (2005). Tolerância. In: P. Galán (Org.). Democracia y virtudes cívicas. (pp. 183-228). Madri: Biblioteca Nueva.

Galtung, J. (2006). Transcender e transformar: uma introdução ao trabalho de conflitos. São Paulo: Palas Athenas.

Galtung. J. (1986). Violência, paz e investigación sobre la paz. Em: Sobre la paz. Barcelona: Ed. Fontamara.

Garapon, A. (1999). Bem Julgar: Ensaio sobre o ritual judiciário. Lisboa: Instituto Piaget.

Gaskins, S., Miller, P. \& Corsaro W. (1992). Theoretical and methological perspectives in the interpretive study of children. Em W. Corsaro \& P. Miller (Orgs.). Interpretive approaches to children's socialization (pp. 5-23). San Francisco, CA: Jossey-Bass Publishers.

Geertz, C. (1989). A interpretação das culturas. Rio de Janeiro: LTC. 
Gilligan, C. (1982). In a differente voice: Psychological theory and women's development. Cambridge: Havard University Press.

González-Rey, F. (2005). Pesquisa qualitativa em psicologia. São Paulo: Pioneira Thomson

Guimarães, M. R. (2005). Educação para a paz: sentidos e dilemas. Caxias do Sul/RS: Educs.

Jahoda, G. (2012). Critical reflections on some recent definitions of "culture". Culture \& Psychology, 18 (3), 289-303. DOI 10.1177/1354067X12446229.

Jares, X. R. (2002). Educação para a paz: sua teoria e sua prática. Porto Alegre: Artmed.

Kohlberg, L. (1984). Essays on moral development. Vol. 2: The psychology of moral development: moral stages, their nature and validation. New York: Harper \& Row.

La Taille, Y. (2000). Universidade de São Paulo. Educação e Pesquisa, São Paulo, v.26, n.1, p.109-121, jan./jun. 2000.

Lima, V. A. (2004). De Piaget a Gilligan: Retrospectiva do Desenvolvimento Moral em Psicologia - um Caminho para o Estudo das Virtudes. Psicologia Ciência e Profissão, 24, $12-23$.

Lourenço, O. M. (1998). Psicologia do desenvolvimento moral. Coimbra: Livraria Almedina.

Madureira, A. F. \& Branco, A. U. (2012). Diversity and inclusion as central values in the construction of a democratic wold. In: A. U. Branco, \& J. Valsiner (Orgs.). Cultural Psychology of Human Values, (pp. 195-235). Charlote, NC: Information Age Publishing.

Madureira, A.F.A. \& Branco, A.U. (2005). Construindo com o outro: Uma perspectiva sociocultural construtivista do desenvolvimento humano. Em M.A. Dessen \& A.L. Costa Júnior (Orgs.), A ciência do desenvolvimento humano: Tendências atuais e perspectivas futuras (pp. 90-109). Porto Alegre: Artmed.

Malinowski, B. (1944). A Scientific Theory of Culture and Others Essays. Chapel Hill, N. Carolina: The University of North Carolina Press.

Manzini, R. G. P. (2013). Bullying no contexto escolar: prevenção da violência e promoção da Cultura da Paz na perspectiva de adultos e crianças. Tese de Doutorado, Universidade de Brasília, Brasília.

Markova, I (2006). Dialogicidade e representações sociais: as dinâmicas da mente. Petrópolis: Vozes.

Martins, L. C. \& Branco, A. U. (2001). Desenvolvimento moral: considerações teóricas a partir de uma perspectiva sociocultural construtivista. Psicologia: Teoria e Pesquisa, 17, 169-177. 
Matos, B. F. (2009). Direito Penal do Inimigo. Acessado em 05/12/2015, disponível em http://www.direitonet.com.br/artigos/exibir/5138/Direito-Penal-do-inimigo.

Mead, M. (1970). Culture and commitment: A study of the generation gap. New York: John Wiley.

Melman, J., Ciliberti, M. E., Aoki, M. \& Figueira Junior, N. (2009). Tecendo redes de paz. Saúde e Sociedade, 18, 66-72. Acessado em 20/09/2009, disponível em http://www.scielo.br.

Ministério da Saúde (2009). Por uma Cultura da Paz, a promoção da Saúde e prevenção da violência. Brasília-DF.

Milani, F. M. (2003). Cultura de Paz x Violência. Em F. M. Milani \& R. C. Jesus (Orgs.). Cultura de Paz: estratégias, mapas e bússolas. Salvador: Inpaz.

Milani, F. \& Branco, A. (2004). Assessing Brazil's Culture of peace and conflict. Peace and conflict, 10, 161-174. New Jersey, USA.

Minayo, M. C. S. (1994). Violência social sob a perspectiva da saúde pública. Cadernos de Saúde Pública, 10, 07-18.

Minayo, M. C. S. \& Souza, E. R. (1999). É possível prevenir a violência? Reflexões a partir do campo da saúde pública. Ciência e Saúde Coletiva, 4, 7-32.

Moreira, L. S. (2011). Cultura de Paz, prevenção da violência e socialização na perspectiva de policiais militares. Dissertação de Mestrado, Universidade de Brasília, Brasília.

Moreira, L. S. \& Branco, U. A. (2012). Cultura de paz, moralidade e virtudes cívicas: contribuições da Psicologia Cultural. Psicologia Argumento, 30(68), 161-170.

Muller, J. (2007). Princípio da não-violência: percurso filosófico. São Paulo: Palas Athenas.

Organização das Nações Unidas (2000). Manifesto 2000. Acessado em 15/09/2009, disponível em http//:www.onu.org

Palmieri, M. W. A. \& Branco, A. U. (2004). Cooperação, competição e individualismo em uma perspectiva sociocultural construtivista. Psicologia: Reflexão e Crítica, 17, 189-198.

Piaget, J. (1994/1932). O juízo moral na criança. São Paulo: Summus.

Ratner, C. (2002) Cultural Psychology. Theory and method. New York: Kluwer academy/Plemum Publishers.

Rengifo-Herrera, F. J. (2014). Desenvolvimento de valores sociais na perspectiva da psicologia semiótico-cultural: um estudo com meninos colombianos e brasileiros em contexto lúdico sugestivo de violência. Tese de Doutorado, Universidade de Brasília, Brasília-DF. 
Rengifo-Herrera, F. J. (2012). The semiotic construction of values of violence in the colombian context. In: A. U. Branco, \& J. Valsiner (Orgs.). Cultural Psychology of Human Values, (pp. 137-159). Charlote, NC: Information Age Publishing.

Roger-Pol Droit (2006). De onde vem a paz ? Em: Imaginar a Paz. Brasília: UNESCO, Paulus Editora.

Rogoff, B. (2005). A natureza cultural do desenvolvimento humano. Porto Alegre: Artmed.

Rosa, A. \& González, F. (2012). Values, Virtues, Citizenship, and Self From a Historical and Cultural Approach. In: A. U. Branco, \& J. Valsiner (Orgs.). Cultural Psychology of Human Values, (pp. 31-62). Charlote, NC: Information Age Publishing. Salvatore, S. (2012). Social life of the sign: Sense-making in society. In J. Valsiner (Ed.), Oxford Handbook of Culture and Psychology, 241-254. New York: Oxford University Press.

Salvatore, S. (2013). The reciprocal inherency of self and context. Interações, 24, 2050 .

Sato, T., Hidaka, T. \& Fukuda, M. (2009). Depicting the Dynamics of Living the Life: The Trajectory Equifinality Model. In: J. Valsiner et al (Eds.). Dynamic Process Methodology in the Social and Developmental Sciences. New York: Springer.

Schnitman, D. (1999). Novos paradigmas na resolução de conflitos. Em: D. Schnitman \& S. Littlejohn (Eds.). Novos paradigmas em mediação (pp. 17-27). Porto Alegre: Artmed.

Scheler, M. (2008). A situação do homem no cosmos. Lisboa: Texto e Grafia.

Seidel, D. (2007). Mediação de conflitos: a solução de muitos problemas pode estar em suas mãos. Brasília: Vida e Juventude.

Senna, S. F. (2007). Protagonismo infantil e promoção da Cultura de Paz: um estudo sociocultural construtivista. Tese de Doutorado, Universidade de Brasília, Brasília.

Secretaria Nacional de Segurança Pública (no prelo). Pesquisa sobre as relações hierárquicas nas Polícias Militares brasileiras. Brasília: Ministério da Justiça.

Secretaria Nacional de Segurança Pública (2008). Curso Nacional de Promotor de Polícia Comunitária. Brasília: Ministério da Justiça.

Skinner, F. (1971). Beyond freedom and dignity. New York: Alfred Knopf.

Shweder, R. A., \& Much, N. C. (1991). Determinations of meaning: Discourse and moral socialization. In W. M. Kurtines \& J. L. Gewirtz (Eds.), Moral development through social interaction (pp. 197-244). New York: Wiley \& Sons.

Sifuentes, T. R., Dessen, M. A., \& Lopes de Oliveira, M. C. (2007). Desenvolvimento humano: desafios para a compreensão das trajetórias probabilísticas. Psicologia Teoria e Pesquisa, 23(4), 379-385. 
Staub, E. (2003). The psychology of good and evil: why children, adults, and other groups help and harm others. New York: Cambridge University Press.

Staub, E. (1991). A conception of the determinants and development of altruism and aggression: motives, the self, and the environment. In: C. Zahan-Waxler, E. M. Cummings \& R. lannotti (Orgs.), Altruism and aggression: biological and social origins (pp. 135-164). Cambridge, UK: Cambridge University Press.

Thelen, E. \& Smith, L. (1998). Dynamic systems theory. In: W. Damon \& R. Lerner (orgs.). Handbook of childpsychology, 1, 563-634. Theoretical models of human development. New York: Wiley.

Tognetta, L. R., \& La Taille, Y. (2008). A formação de personalidades éticas: representações de si e moral. Psicologia: Teoria e Pesquisa, 24, 181-188.

Trojanowicz, R \& Bucqueroux, B. (1994). Policiamento Comunitário: como começar?. Rio de Janeiro: Policalerj.

Turiel, E. (1993). The development of social knowledge: morality and convention. Cambridge: Cambridge University Press.

Unesco (1991). Ato Constitutivo. Promulgado pelo Decreto $n^{\circ} 362$, República Federativa do Brasil.

Unesco (1995). Declaração dos Princípios sobre a Tolerância. Acessado em 15/09/2009, disponível em http://unesdoc.unesgo.org

Valsiner, J. (2014). Invitation to Cultural Psychology. London: Sage.

Valsiner, J. (2012). Culture in minds and societies: foundations of cultural psychology. New York: Delhi Sage

Valsiner, J. (2009) War in peace. Personal cultures of peace in amidst carnivals of destruction. Em: De Rivera, J (Ed.) Handbook of building cultures of peace. (pp.43 56) New York: Springer.

Valsiner, J. (2007). Culture in minds and societies: foundations of cultural psychology. New York: Delhi Sage

Valsiner, J. (2005). Soziale and emotionale Entwicklungdaufgaben in kulturellen context. In: J. Asendorpf \& H. Rauh (Orgs.). Enzyklpadie der psychologie, vol. 3. Soziale, emotionali und Personlichheitsentwicklung. Gottingen: Hogrefe.

Valsiner, J. (2003). Beyond social representations: a theory of enablement. Papers on Social Representations, 12, 1-16.

Valsiner, J. (1998). The guided mind. A sociogenetic approach to personality. Cambridge: Harvard University Press.

Valsiner, J, Branco, A \& Dantas, C. (1997) Co-construction of human development: Heterogeneity with parental belief orientations. In: J. E. Grusec \& L. Kuczinski (Eds.), 
Parenting and children's internalization of values: A Handbook of contemporary theory (pp. 283-304) NewYork: Wiley.

Valsiner, J. \& Cairns, R. (1992). Theoretical perspectives on conflict and development. Em C.V. Shantz \& W.W. Hartup (Orgs.), Conflict in child and adolescent development (pp. 15-35). Cambridge, UK: Cambridge University Press.

Vygotsky, L. (1989). Pensamento e Linguagem. São Paulo: Martins Fontes.

Wortmeyer, D. S. (2007). Desafios da internalização de valores no processo de socialização organizacional: um estudo da formação de oficiais do Exército. Dissertação de Mestrado, Universidade Estadual do Rio de Janeiro, Rio de JaneiroRJ.

Wilkinson, S. (2008). Focus Group. Em J. Smith (Org.). Qualitative psychology. (pp.186-206). Londres: Sage.

Yokoy, T., Branco, A. U. \& Lopes de Oliveira, M. C. (2008). Pesquisa qualitativa e desenvolvimento humano: aspectos históricos e tendências. Revista do Departamento de Psicologia-UFF, 20, 357-376.

Zittoun, T. (2009). Dynamics of life-course transitions - a methodological reflections. In J. Valsiner, P. C. M. Molenaar, M. C. D. P. Lyra, \& N. Chaudhary (Eds.), Dynamic Process Methodology in the Social and Developmental Sciences (pp. 405-430). New York: Springer.

Zittoun, T.; Mirza, N. M.; Perret-Clermont, A-N. (2007). Quando a noção de cultura é considerada nas pesquisas em psicologia do desenvolvimento. Educar, Curitiba, 30, 65-76. 
ANEXOS 
Anexo 1 - Roteiro de entrevista semiestruturada individual - Cadetes e Tenentes QOPM

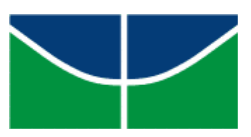

Universidade de Brasília- Instituto de Psicologia

Instituto de Psicologia

Programa de Pós-Graduação em Processos de Desenvolvimento Humano e Saúde

Roteiro de entrevista semiestruturada - Cadetes e Tenentes QOPM

Identificação (iniciais):

Idade: Nome Fictício:

Tempo na PM: Posto: Unidade de trabalho:

Escolaridade: Sexo: Religião:

Estado Civil: Filhos:

Naturalidade: Data:

Período: de hs às hs; Tempo Total:

Obs:

ESCLARECIMENTO: Nós vamos conversar sobre valores humanos, certo? Não é teste e não tem certo $x$ errado. Os temas são muito complexos e estão sendo estudados agora em maior detalhe. Por isso, precisamos da sua opinião subjetiva sobre o tema.

1. O que motivou você a ingressar na carreira de oficial da Polícia Militar?

2. Você gosta de fazer parte da Polícia Militar, hoje? Por quê?

3. O que você considera como sendo o seu ponto forte para contribui com o trabalho da PM?

4. Agora vamos falar das práticas concretas da polícia militar. Você diria que as ações da Polícia Militar envolvem algum tipo de violência? Como assim? Explicar e dar exemplo. O que poderia ser feito diferente?

5. Em quais casos você acha que as ações violentas da PM se justificam? Como a PM orienta os policiais a lidarem com estes casos?

6. Mas, afinal, o que você entende como violência? O que é violência? Se você tivesse de definir para alguém, como você definiria? Dê exemplos de vários tipos de violência que você observa no dia a dia! (no mínimo 3) 
7. Quando você acha que uma pessoa precisa utilizar de violência? Quando ela é necessária? Exemplos!!!

8. Sabemos que é melhor prevenir do que reprimir! Mas é possível mesmo prevenir todo tipo de violência? (Exemplos e perguntar como seria a prevenção ou que fazer....)

9. Para você, a PM atua na prevenção da violência? Como?

10. Agora eu gostaria de saber se você já teve que enfrentar uma situação difícil, que envolveu violência. Como foi? O que você fez? O que sentiu? Você poderia ter agido de outra forma? Como assim? Algum outro exemplo? (Explorar).

11. Em que situações, durante o seu Curso de Formação de Oficiais, questões como essas que eu estou fazendo foram discutidas com você e sua turma? Teve alguma disciplina, ou treinamento em o tema da violência tenho sido discutido??? (Explorar)

12. Atualmente, fala-se muito sobre a construção da paz. Como você define "paz"?

13. Você acha possível construir a paz no mundo de hoje? De que maneira?

14. Você acha que a Polícia Militar, hoje, promove a construção da paz? E no Curso de Formação de Oficiais? Que sugestões ou ideias você daria? (Você pode propor tudo que Ihe vier à cabeça, as entrevistas não vão ser identificadas, OK?)

15. Nós falamos sobre a Paz. Mas e o conflito? Todo conflito é negativo? Por que? (Explorar)

16. Agora eu vou mostrar algumas imagens e um vídeo, e gostaria de ouvir como você se sente a respeito. Sinta-se totalmente à vontade para falar, lembrando que a entrevista é sigilosa.

17. Para finalizar, e lembrando o anonimato da pesquisa, você teria mais alguma recomendação para a PM, que você gostaria de fazer, relacionada com essa nossa conversa?

Muito Obrigada por sua colaboração! 
Anexo 2 - Roteiro de Grupo Focal - Cadetes e Tenentes QOPM

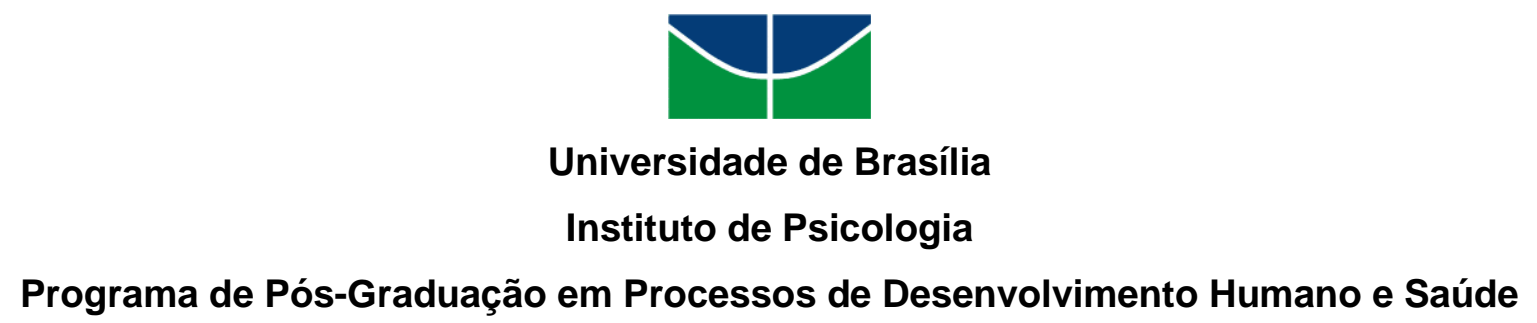

Roteiro de Grupo Focal - Cadetes e Tenentes QOPM

Identificação:

Data: Período: de hs às hs; Tempo Total:

ESCLARECIMENTO: Essa é a segunda parte da nossa pesquisa como eu havia falado no momento da entrevista. Nós vamos continuar conversando sobre valores humanos, agora em grupo. Essa nossa conversa não é nenhum teste, e não tem certo ou errado, eu preciso da opinião subjetiva de vocês sobre a temática abordada, certo?

1 - Então, eu vou iniciar apresentando uma situação para vocês discutirem e depois realizarem uma tarefa, certo?

\section{A HISTÓRIA DA MARIA}

MARIA era casada com JOÃO e eles se amavam. Eles moravam num morro onde atuavam duas gangues de bandidos, mas o casal vivia honestamente. O morro era dividido pelas gangues, que protegiam os moradores, mas brigavam demais entre si. Depois de um certo tempo, JOÃo começou a chegar cada vez mais tarde em casa, e não ligava mais para a mulher. MARIA se sentiu abandonada e procurou PAULO, que morava do outro lado do morro. MARIA voltava para casa sempre antes do marido chegar. Num dia, quando voltava, ela viu que os BANDIDOS daquela gangue estavam atacando as pessoas que passavam pela única ponte que separava as duas partes do morro. Ela correu de volta para a casa de PAULO e pediu proteção. Ele respondeu que não poderia ajudá-la e que o problema era dela. Ela, então procurou um AMIGO. Este foi com ela até a ponte, mas acovardou-se diante da presença dos bandidos da gangue, e não teve coragem de enfrentá-los. MARIA, então, resolveu procurar o único TAXISTA que trabalhava ali. Este aceitou levá-la por outro caminho, mas isso iria lhe custar $\mathrm{R} \$ 80,00$. MARIA, porém, não tinha dinheiro. Insistiu e implorou, mas o TAXISTA foi 
irredutível. Ela resolveu, então, arriscar e passar pela tal ponte, mas os bandidos a pegaram e bateram nela até a morte.

Tarefa: Colocar os seis personagens (João, Maria, Paulo, o Amigo, o Taxista, os Bandidos) em ordem decrescente de culpa pela morte de Maria. Ou seja, coloque em primeiro lugar o maior responsável pelo que ocorreu e os restantes em ordem decrescente, ficando em sexto lugar o menos culpado.

\section{2 - Agora, uma nova situação para vocês discutirem...}

\section{A BOMBA E O POLICIAL MILITAR}

Você é um policial militar que acaba de capturar um assassino acusado de colocar bombas em locais públicos. Seus crimes já causaram a morte de muitas pessoas. Porém, O Bandido afirma que, antes de ser preso, ele já havia colocado uma bomba em um local e se nega a revelá-lo. Vocês temem que essa bomba possa ser detonada, matando milhares de pessoas. O que vocês fariam para conseguir essa informação? No caso dele se recusar a dar a informação, o que mais poderia ser feito?

\section{3 - Agora eu tenho algumas questões sobre as quais eu gostaria de ouvir a opinião de vocês, certo? Se sintam à vontade para responder com total liberdade!}

a) Durante a experiência de vocês na APM, quais as práticas e as regras da instituição que vocês acreditam que mais estão ajudando na formação de vocês como oficiais? O que mais? Vocês acham que estas práticas funcionam? Por quê? Vocês teriam sugestões? [Perguntar se existe algo na rotina diária ou semanal especial para "militares", ou seja, algo que não acontece em outros cursos de formação não-militares.]

b) E o que vocês pensam sobre os RITUAIS E SOLENIDADES MILITARES dos quais vocês têm que participar? Quais são? Para que eles servem? O que sentem a respeito?

c) De quais práticas e experiências aqui na APM VOCÊS MAIS GOSTARAM até agora? E de quais não gostaram? Por quê? Como se sentem a respeito?

d) O que vocês acham que é MAIS IMPORTANTE NA FORMAÇÃO do Oficial PM? Por quê? Quais as SUGESTÕES que vocês fariam à coordenação do curso para contribuir ainda mais para uma boa formação do oficial? [Explorar] 
Anexo 3 - Roteiro de Entrevista Individual Semiestruturada - Coordenador CFO

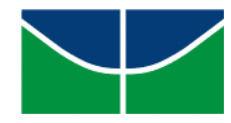

Universidade de Brasília

Instituto de Psicologia

Programa de Pós-Graduação em Processos de Desenvolvimento Humano e Saúde

Roteiro de entrevista semiestruturada - Coordenador do Curso de Formação de Oficiais

Identificação (iniciais): Idade: Nome Fictício:

Tempo na PM: Posto: Unidade de trabalho:

Sexo: Escolaridade: Religião:

Estado Civil: Filhos:

Naturalidade:

Data:

Período: de hs às hs; Tempo Total:

Obs:

ESCLARECIMENTO: Nós vamos conversar sobre valores humanos, certo? Não é teste e não tem certo $x$ errado. Os temas são muito complexos e estão sendo estudados somente agora em maior detalhe. Por isso, precisamos da sua opinião subjetiva sobre o tema, enquanto coordenador do Curso de Formação de Oficias da PM.

1. Eu gostaria de começar perguntando por que você escolheu a carreira de oficial da Polícia Militar? Você gosta desta carreira?

2. O que você considera como o seu ponto forte em relação ao trabalho na PM.

3. O que o motivou a trabalhar na área de ensino da Polícia Militar? Como avalia seu trabalho como coordenador (aspectos positivos e dificuldades)

4. Agora eu gostaria de perguntar sua opinião sobre conflito. O que você considera como sendo um conflito?

5. Existe, para você, algum tipo de conflito que possa ser importante ou positivo de alguma maneira? Por quê? Dê exemplos.

6. Fale-me sobre o que você entende como violência. Se você tivesse de definir para alguém, como você definiria violência? Explorar...

7. Agora vamos pensar na relação entre conflito e violência. Você acha que todo conflito envolve violência? Explicar. 
8. O que funciona mais, a punição, a repressão, ou a prevenção? Como é possível prevenir? Exemplos e perguntar no caso dos exemplos que o participante deu anteriormente!

9. Você acha que o CFO discute A relação entre repressão e prevenção da violência? Como? Em quais atividades pedagógicas? Você acha suficiente? Tem sugestões?

10. Agora vamos falar das práticas concretas da polícia militar. Você diria que as ações da polícia militar envolvem algum tipo de violência? Como assim? Explicar e dar exemplo. Em quais casos você acha que a violência por parte da PM é necessária?

11. Agora, de uma maneira mais geral, quando você acha que usar a violência faz sentido? Ou seja, quando você acha que ela é necessária? Exemplos!!!

12. Que aspectos do curso de formação militar você, hoje, consegue identificar que poderiam, em princípio favorecer algum tipo de violência? Explicar...(que tipo, como ocorre, se concorda ou não etc). Como isto poderia ser resolvido?

13. Fala-se muito sobre a construção da paz. Como você definiria paz? É possível construir a paz no mundo de hoje? De que maneira?

14. Você acha que o CFO promove a construção da paz? Como? Em quais atividades? Dar exemplos.

15. O que, na sua opinião, poderia ser feito em relação à Matriz Curricular do CFO para favorecer a construção e discussão de ações do oficial da PM voltada para construir a paz?

16. Atualmente, as ações concretas os policiais militares em serviço favorecem a construção da paz na sociedade? Por quê (dar exemplos)?

17. Quais ações concretas os policiais militares poderiam realizar para favorecer a paz na sociedade? Dê exemplos...

18. Gostaria de pedir para você outras sugestões ou ideias para construir uma Cultura de Paz na sociedade. Sinta-se à vontade de propor tudo que lhe vier à cabeça, e não se esqueça que as entrevistas não serão identificadas, certo?

19. Como a PM, enquanto instituição, poderia colaborar com esta construção? De que maneira? Exemplos ou sugestões.

20. Para finalizar, você gostaria de dizer mais alguma outra coisa relacionada a essa nossa conversa?

Muito Obrigada por sua colaboração! 
Anexo 4 - Roteiro de Entrevista Individual Semiestruturada - Instrutora do CFO

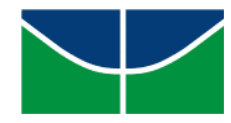

Universidade de Brasília

Instituto de Psicologia

Programa de Pós-Graduação em Processos de Desenvolvimento Humano e Saúde

Roteiro de entrevista semiestruturada - Instrutora do Curso de Formação de

Oficiais

Identificação (iniciais): Idade: Nome Fictício:

Tempo na PM: Posto: Unidade de trabalho:

Sexo: Escolaridade: Religião:

Estado Civil:

Naturalidade:

Data:

Disciplina (s) ministrada (s):

Período: de :__ hs às hs; Tempo Total:

Obs:

ESCLARECIMENTO: Nós vamos conversar sobre valores humanos, certo? Não é teste e não tem certo $x$ errado. Os temas são muito complexos e estão sendo estudados agora em maior detalhe. Por isso, precisamos da sua opinião subjetiva sobre o tema, enquanto instrutora do Curso de Formação de Oficias da PM.

1. Eu gostaria de começar perguntando o que o motivou a trabalhar na área de ensino da Polícia Militar? Há quanto tempo você ministra aula aqui?

2. Para você, quais são os pontos positivos e quais as dificuldades que você encontra em seu trabalho como instrutor na PM?

3. Em relação ao CFO, o que você acha do curso? De que maneira a sua disciplina contribui para essa formação? Explicar.

4. Agora eu gostaria de perguntar sua opinião sobre conflito. O que você considera como sendo um conflito? Existe, para você, algum tipo de conflito que possa ser importante ou positivo de alguma maneira? Por quê? Dê exemplos.

5. Fale-me sobre o que você entende como violência. Se você tivesse de definir para alguém, como você definiria violência? Explorar...

6. Agora vamos pensar na relação entre conflito e violência. Você acha que todo conflito envolve violência? Explicar. 
7. O que funciona mais, a punição, a repressão, ou a prevenção? Como é possível prevenir? Exemplos.

8. Você acha que o CFO discute essa relação entre repressão e prevenção da violência? Como? Em quais atividades pedagógicas? Você acha suficiente?

9. Em sua disciplina, você analisa ou discute com seus alunos alguma questão relacionada ao tema violência? E sobre a questão da paz? Dê todos os exemplos que você puder lembrar!

10. Que materiais você utiliza com os alunos sobre este tópico? (pedir as referências completas depois, bem como o programa que o professor usa em sua disciplina!!!!)

11. Nesses exemplos, quais as mensagens que você procura passar para seus alunos? Eles aceitam? Eles têm alguma resistência? Como assim (explicar).

12. Agora vamos falar das práticas concretas da polícia militar. Você diria que as ações da polícia militar envolvem algum tipo de violência? Como assim? Quando o policial militar deve agir com violência? Explicar e dar exemplo.

13. De uma maneira geral, você acha que, em algum momento, é necessário a pessoa utilizar de violência? Em algum momento faz sentido, ela utiliza de violência? Exemplos!!!

14. Que aspectos do CFO você consegue identificar que poderiam, em princípio, favorecer algum tipo de violência? Explicar... (que tipo, como ocorre, se concorda ou não etc). Como isto poderia ser resolvido?

15. Fala-se muito sobre a construção da paz. Como você definiria paz? É possível construir a paz no mundo de hoje? De que maneira?

16. Você acha que o CFO promove a construção da paz? Como? Em quais atividades? Em quais disciplinas isso é discutido?

17. O que, na sua opinião, a Matriz Curricular do CFO favorece a formação do Oficial da PM voltada para a paz? Você acredita que a sua disciplina tem alguma contribuição nesse sentido? Qual?

18. Pra finalizar a nossa conversa aqui, gostaria de pedir ideias ou sugestões para que a PM possa contribuir com a Cultura de Paz na sociedade. Sinta-se à vontade de propor tudo que a respeito, certo?

\section{Muito Obrigada por sua colaboração!}


Anexo 5 - Termo de Ciência e Autorização do Comando Geral da Polícia Militar do Estado X.

\section{TERMO DE CIÊNCIA}

Declaro para todos e devidos fins estar ciente e autorizo LETÍCIA DE SOUSA MOREIRA - CAP QOSPM/TO, a realizar na Polícia Militar sua pesquisa de Doutorado em Processos de Desenvolvimento Humano e Saúde, da Universidade de Brasília - UnB, com o tema: "Violência e Paz: conceitos, valores e práticas de oficiais em diferentes níveis da carreira na Polícia Militar novembro de 2013.

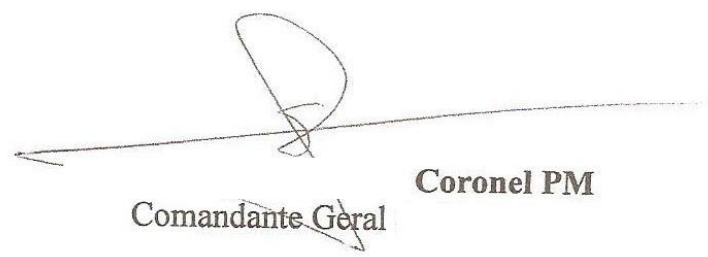


Anexo 6 - Parecer Consubstanciado do Comitê de Ética e Pesquisa - CEP / UnB

\author{
INSTITUTO DE CIENCIAS \\ HUMANAS / UNIVERSIDADE \\ DE BRASÍLIA / CAMPUS
}

\title{
QRiataforma
}

PARECER CONSUBSTANCIADO DO CEP

\section{DADOS DO PROJETO DE PESQUISA}

Título da Pesquisa: VIOLENCIA E PAZ: CONCEITOS, PRÁTICAS E VALORES DE OFICIAIS EM DIFERENTES NIVEIS DA CARREIRA NA POLICIA MILITAR

Pesquisador: LETICIA DE SOUSA MOREIRA

Área Temática:

Versão:

CAAE: $43925314.6 .0000,5540$

Instituiçäo Proponente: Instituto de Psicologia -UNB

Patrocinador Principal: Financiamento Próprio

DADOS DO PARECER

Número do Parecer: 1.045 .766

Data da Relatoria: $24 / 04 / 2015$

Apresentação do Projeto:

Este é um projeto de doutorado do Programa de Pós-Graduação em Processos de Desenvolvimento Humano e Saúde - IP/UnB

Considerando o contexto sócio-histórico cultural de uma instituição militar, este estudo visa identificar e analisar indicadores do impacto do Curso de Formação de Oficiais (CFO)e da experiência profissional dos Oficiais do Quadro Operacional da Polícia Militar (QOPM) na construção de conceitos, valores e expectativas profissionais relacionadas à violência e à paz, e de que forma tais indicadores atuam como agentes catalisadores desse processo, para que se tornem agentes promotores de uma Cultura de Paz na sociedade.

A metodologia utilizada será com base na epistemologia qualitativa.

Como instrumentos de pesquisa, serão utilizados roteiros para entrevistas individuais semiestruturada com 15 policiais militares, sendo 6 Cadetes e 6 Tenentes QOPM; 1 coordenador do CFO; e 2 instrutores do CFO. Também serão realizadas 2 sessőes de grupo focal, sendo 1 com os Cadetes e 1 com os Tenentes. O procedimento de análise das narrativas será conforme o modelo construtivo-interpretativo. A realizaçăo deste trabalho pretende, ainda, construir subsídios e aportes teóricos para

Endereço: CAMPUS UNIVERSITARIO DARCY RIBEIRO - ICC ¿ALA NORTE ¿ MEZANINO ¿ SALA B1 ¿ 606 (MINHOCÃO Bairro: ASA NORTE

UF: DF Município: BRASILIA

Telefone: (61)3307-2760 CEP: $70.910-900$

E-mail: ihd@unb.br 


\section{INSTITUTO DE CIENCIAS HUMANAS / UNIVERSIDADE DE BRASÍLIA / CAMPUS}

Continuaçăo do Parecer: 1.045 .766

desenvolver açőes de formação continuada que levem os policiais militares a refletirem sobre suas práticas e se tornarem promotores da Cultura de Paz no exercício das diversas funções que desempenham, dentro $\Theta$ fora da instituição.

Objetivo da Pesquisa:

Objetivo Primário:

Identificar e analisar indicadores do impacto do Curso de Formação de Oficiais e da experiência profissional dos Oficiais do Quadro Operacional da Polícia Militar na construção de conceitos, valores e expectativas profissionais relacionadas à violência e à paz, e de que forma tais indicadores atuam como agentes catalisadores desse processo.

Objetivo Secundário:

1. Levantar indicadores a partir das narrativas de Cadetes, Aspirantes, e Tenentes QOPM dos conceitos, valores, expectativas e práticas profissionais, relacionados à Violência e Paz;

2. Identificar o impacto do CFO e da experiência profissional de Oficiais, como agentes catalisadores na construção de conceitos, valores, expectativas e práticas profissionais, relacionados à Violência e à Paz; 3. Analisar significaçőes e avaliações feitas pelo coordenador do CFO e professores das disciplinas, Desenvolvimento Interpessoal, Direitos Humanos e Psicologia Social

(disciplinas possivelmente relacionadas ao tema) com relaçăo ao tema;

4. Analisar a matriz curricular e as atividades extra-curriculares do CFO.

\section{Avaliação dos Riscos e Beneficios:}

A pesquisadora considera não haver riscos, apenas benefícios quanto o melhor conhecimento da temática $e$ possibilitar a melhor qualificação dos egressos do CFO.

Comentários e Considerações sobre a Pesquisa:

O projeto de pesquisa está apresentado de forma clara e atende os preceitos éticos.

\section{Consideraçōes sobre os Termos de apresentação obrigatória:}

Todos os termos apresentados estão adequados.

- TCLE

- Roteiro de entrevista

- Roteiro do grupo focal

Endereço: CAMPUS UNIVERSITARIO DARCY RIBEIRO - ICC ¿ ALA NORTE ¿ MEZANINO ¿ SALA B1 ¿606 (MINHOCÃO Bairro: ASA NORTE

UF: DF Município: BRASILIA

Telefone: (61)3307-2760 CEP: $70.910-900$

E-mail: ind@unb.br 


\section{INSTITUTO DE CIENCIAS HUMANAS / UNIVERSIDADE DE BRASÍLIA / CAMPUS}

Continuação do Parecer: 1.045 .766

Recomendações:

Nenhuma recomendação

Conclusões ou Pendências e Lista de Inadequações:

Nenhuma pendência

Situação do Parecer:

Aprovado

Necessita Apreciação da CONEP:

Não

Consideraçőes Finais a critério do CEP:

BRASILIA, 02 de Maio de 2015

Assinado por:

Lívia Barbosa

(Coordenador)

Endereço: CAMPUS UNIVERSITARIO DARCY RIBEIRO - ICC ¿ ALA NORTE ¿ MEZANINO ¿ SALA B1 ¿ 606 (MINHOCÃO Bairro: ASA NORTE CEP: $70.910-900$ Município: BRASILIA

UF: DF

Telefone: (61)3307-2760
E-mail: ind@unb.br 


\section{Anexo 7 - Termo de Consentimento Livre e Esclarecido}

Prezado (a) Policial Militar,

Você está sendo convidado (a) para participar de uma pesquisa de Doutorado sobre valores humanos no contexto da Polícia Militar, pela qual sou responsável. Esclareço que a sua participação nas entrevistas e no grupo focal é voluntária, você está livre para participar ou não do estudo, e a qualquer momento, você poderá deixar a pesquisa, se assim desejar. Caso você aceite o convite, gostaria de sua autorização para que a entrevista seja gravada em áudio e as sessões do grupo focal sejam filmadas, com o intuito de permitir a realização do estudo. É importante esclarecer que todas as informações serão confidenciais, garantindo o anonimato dos participantes.

Sou Capitã Psicóloga da PM, e aluna do Programa de Doutorado em Processos de Desenvolvimento Humano e Saúde, do Instituto de Psicologia da Universidade de Brasília. Estou realizando esta pesquisa que objetiva identificar e analisar indicadores do impacto do Curso de Formação de Oficiais (CFO) e da experiência profissional dos Oficiais do Quadro Operacional da Polícia Militar (QOPM) na construção de conceitos, valores e expectativas profissionais relacionadas à questão da paz. A partir dos indicadores empíricos obtidos, pretende-se adquirir subsídios para melhorar a formação do oficial com relação às temáticas abordadas.

Neste estudo será necessário realizar entrevistas individuas com Cadetes, Aspirantes e Tenentes do Quadro Operacional da Polícia Militar, bem como uma sessão de grupo focal com cada categoria. Como colocado anteriormente, a participação na entrevista é voluntária e as respostas são livres de qualquer obrigação ou dever. Informo também, que a entrevista terá em torno de uma hora de duração, a sessão de grupo focal em torno de duas horas e a identificação do participante será mantida em total sigilo e sob minha responsabilidade. Os dados obtidos serão utilizados apenas para os objetivos da pesquisa.

Caso tenha alguma dúvida sobre a pesquisa, você poderá me contatar pelo telefone (62) 8208-0440, ou no endereço eletrônico leticiamoreirapsi@gmail.com. Também poderá buscar informações adicionais no Comitê de Ética e Pesquisa da Universidade de Brasília, pelo email ind@unb.br ou telefone (61) 3307-2760. Caso tenha interesse em conhecer mais sobre esta pesquisa, por favor, indique um e-mail de contato.

Desde já, agradeço sua atenção e colaboração. 
Cordialmente,

Letícia de Sousa Moreira - CAP QOSPM RG 05.180/1

Doutoranda do PGPDS - Universidade de Brasília

Sim, concordo em participar da entrevista, com a gravação em áudio e vídeo.

Nome:

Assinatura:

E-mail (opcional):

Data: 


\section{Anexo 8 - Termo de Cessão e Uso de Imagem}

Prezado (a) Policial Militar,

Você está sendo convidado (a) para participar de uma pesquisa de Doutorado sobre valores humanos no contexto da Polícia Militar, pela qual sou responsável. Sou Capitã Psicóloga da Polícia Militar, e aluna do Programa de Doutorado em Processos de Desenvolvimento Humano e Saúde, do Instituto de Psicologia da Universidade de Brasília.

Neste estudo será necessário realizar entrevistas individuas gravadas em áudio e uma sessão de grupo focal filmada. Para tanto, peço a autorização de uso da sua imagem e voz para a finalidade da pesquisa, descrita no Termo de Consentimento Livre e Esclarecido (TCLE).

Informo que a identificação do participante será mantida em total sigilo, as imagens e áudios obtidos com a pesquisa ficarão sob minha responsabilidade, serão utilizados apenas no contexto da pesquisa e não serão divulgadas.

Caso tenha alguma dúvida sobre a pesquisa, você poderá me contatar pelo telefone (62) 8208-0440, ou no endereço eletrônico leticiamoreirapsi@gmail.com. Também poderá buscar informações adicionais no Comitê de Ética e Pesquisa da Universidade de Brasília, pelo email ind@unb.br ou telefone (61) 3307-2760.

Desde já, agradeço sua atenção e colaboração.

Cordialmente,

Letícia de Sousa Moreira - CAP QOSPM RG 05.180/1

Doutoranda do PGPDS - Universidade de Brasília

Sim, autorizo o uso de minha imagem e voz nesta pesquisa.

Nome:

Assinatura:

E-mail (opcional): Data: 
Anexo 9 - Imagens utilizadas nas Entrevistas Individuais com os Cadetes e Tenentes

Imagem 1 - Civil chutando o rosto de um policial militar

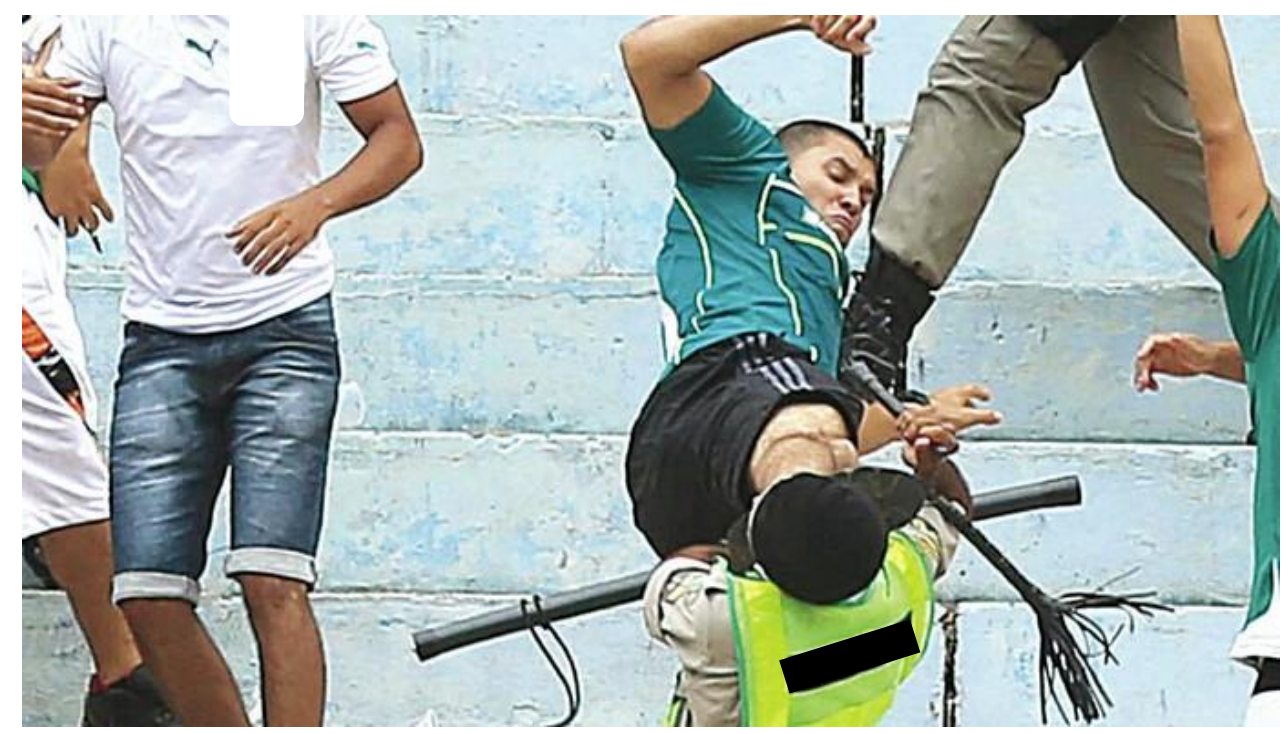

Imagem 2 - Policiais militares agredindo um civil

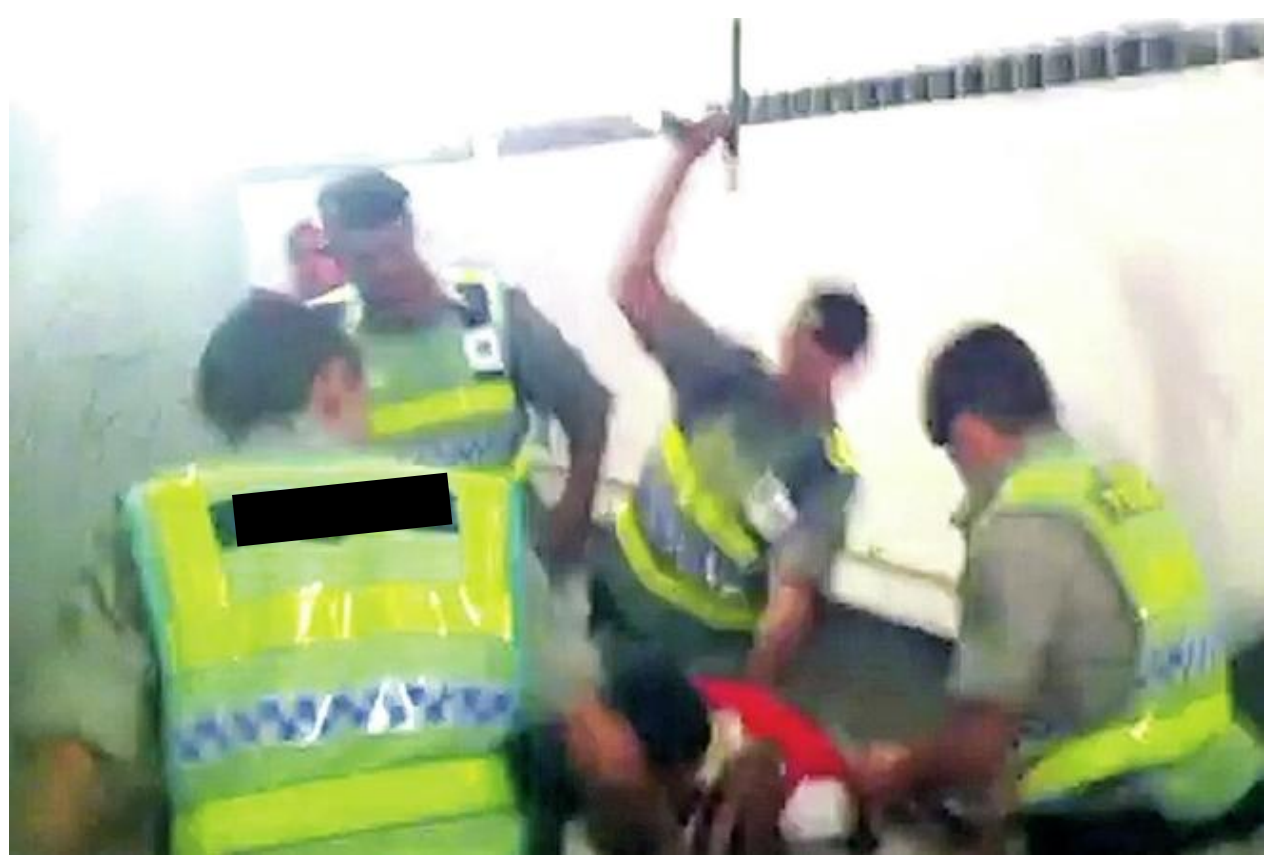

Obs: Imagem desfocada no original em razão do meio de captação. 
Imagem 3 - Coronel da PM agredido em uma manifestação

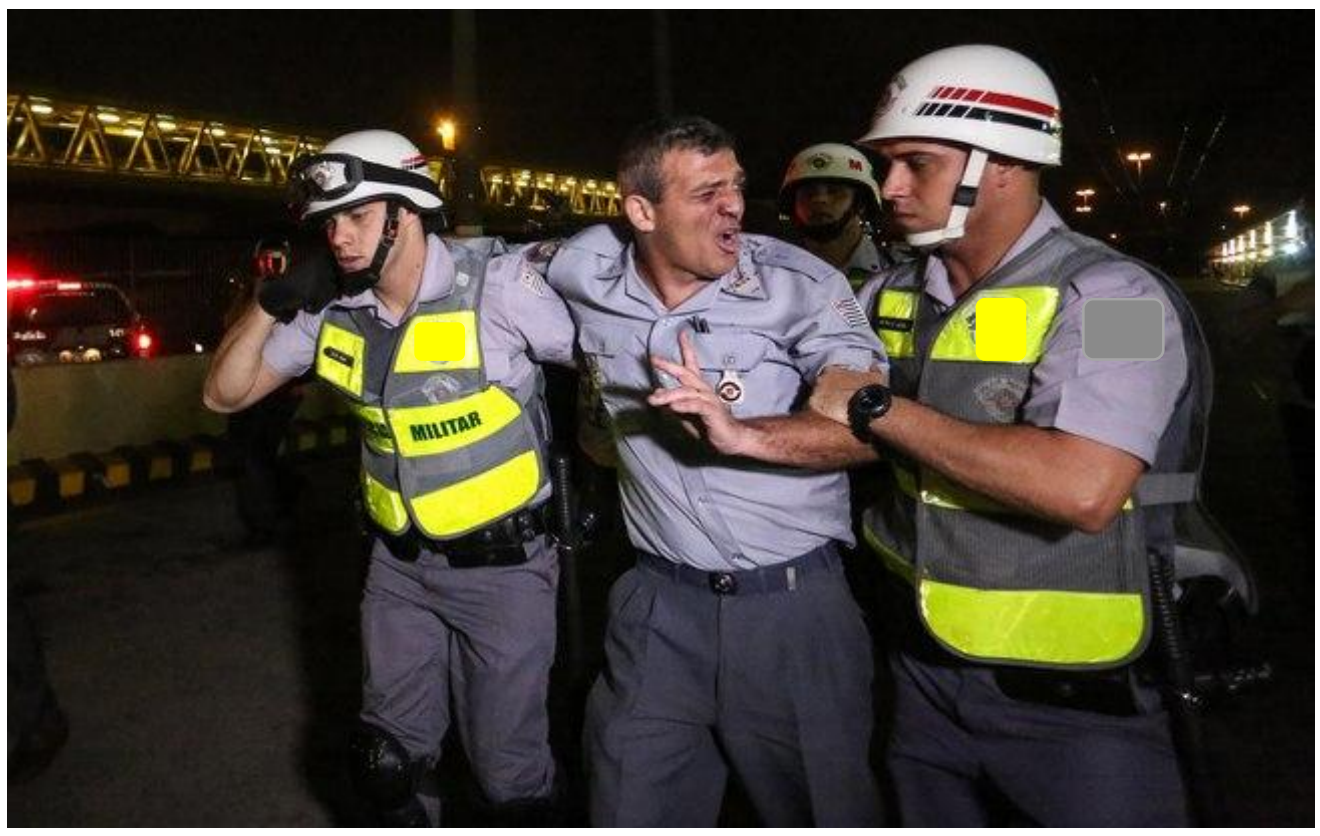

Imagem 4 - Policiais fazendo contenção de um civil em manifestação.

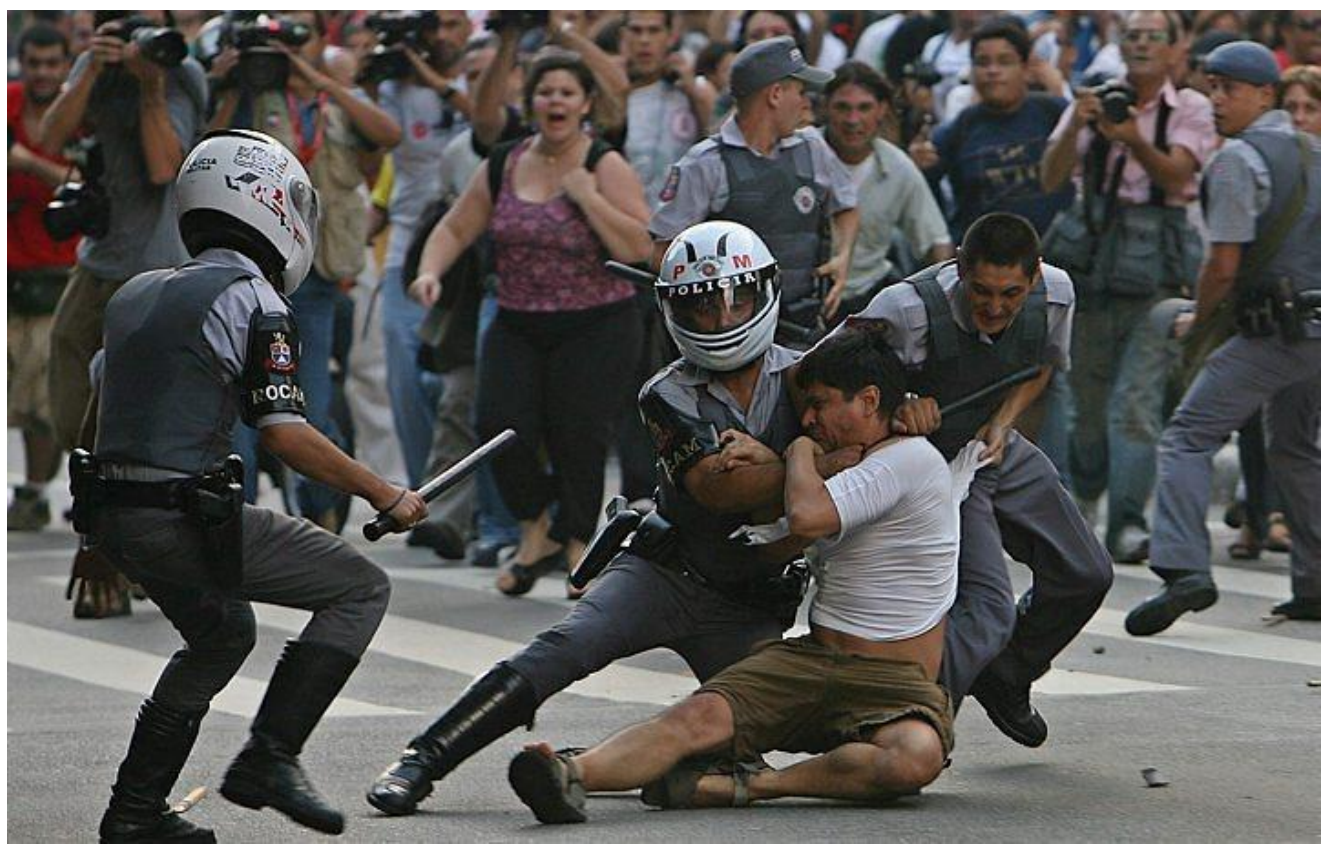




\section{GLOSSÁRIO}

APM: Academia de Polícia Militar, local onde todos os cursos de formação, atualização e aperfeiçoamento são realizados pela PM.

ASPIRANTE a OFICIAL: Posto ou graduação ao qual é promovido o Cadete imediatamente após a formatura no CFO.

CADETES: Alunos-Oficiais, que cursam o CFO.

CAPITÃO: Posto ou graduação ao qual é promovido o Tenente após cumprido os requisitos exigidos pela $\mathrm{PM}$.

CFO: Curso de Formação de Oficiais.

HIERARQUIA: Um dos pilares fundamentais da Polícia Militar.

OFICIAIS: Ciclo que compõe a segunda parte da hierarquia da PM.

ORDEM UNIDA: Formação habitual de marcha, de parada ou de reunião dos componentes de uma tropa.

PM: Polícia Militar.

POSTO ou GRADUAÇÃO: Local ocupado na hierarquia. Na PM o ciclo das Praças segue a ordem: Aluno-soldado, Soldado, Cabo, 3ํㅗㅇ Sargento, 2 Sargento, 1 Sargento, SubTenente. No ciclo dos Oficiais: Cadete (aluno-oficial), Aspirante a Oficial, $2^{\circ}$ Tenente, $1^{\circ}$ Tenente, Capitão, Major, Tenente-Coronel e Coronel.

PRAÇAS: Ciclo que compõe a primeira parte da hierarquia da PM.

SIMVE: Serviço de Interesse Militar Voluntário Especial - Programa criado pela PM do Estado $X$, que recrutou, selecionou e treinou reservistas do Exército para atuar na Segurança Pública pelo período de 2 anos. Programa foi destituído pelo Supremo Tribunal Federal, em abril de 2015.

STIVE: Expressão usualmente utilizada entre os policiais militares da instituição pesquisada para referir-se aos colegas.

TENENTE: Posto ou graduação ao qual é promovido o Aspirante a Oficial, após o tempo estabelecido pela PM para essa primeira etapa do oficialato. Normalmente após 1 ano como Aspirante. 